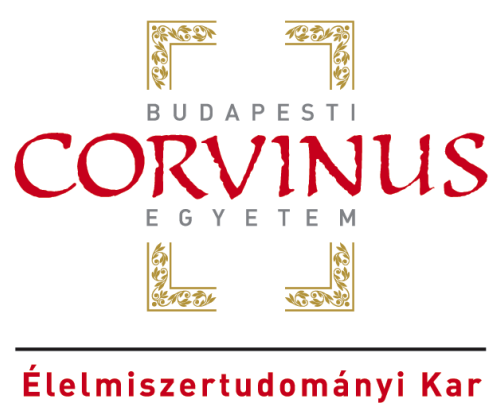

\title{
TECHNOLÓGIAI MÜVELETEK HATÁSAI AZ EGRI BIKAVÉR ÉLETTANILAG AKTÍV VEGYÜLETEINEK ÖSSZETÉTELÉRE ÉS ÉRZÉKSZERVI TULAJDONSÁGAIRA
}

\section{Balga Irina}

Doktori Értekezés

Témavezetö:

Kállay Miklós

Készült:

Budapesti Corvinus Egyetem

Kertészettudományi Kar

Szőlészeti és Borászati Intézet

Borászati Tanszék 


\title{
A doktori iskola
}

megnevezése: Élelmiszertudományi Doktori Iskola

tudományága: Élelmiszertudományok

vezetője:

\author{
Dr. Felföldi József \\ egyetemi tanár, DSc \\ Budapesti Corvinus Egyetem \\ Élelmiszertudományi Kar \\ Fizika-Automatika Tanszék
}

\author{
Témavezető: $\quad$ Dr. Kállay Miklós \\ egyetemi tanár, CSc \\ Budapesti Corvinus Egyetem \\ Kertészettudományi Kar \\ Szőlészeti és Borászati Intézet \\ Borászati Tanszék
}

\section{A doktori iskola- és a témavezető jóváhagyó aláírása:}

A jelölt a Budapesti Corvinus Egyetem Doktori Szabályzatában elöírt valamennyi feltételnek eleget tett, a mühelyvita során elhangzott észrevételeket és javaslatokat az értekezés átdolgozásakor figyelembe vette, ezért az értekezés védési eljárásra bocsátható. 
A Budapesti Corvinus Egyetem Élettudományi Területi Doktori Tanács 2014. év december 02. -i határozatában a nyilvános vita lefolytatására az alábbi Bíráló Bizottságot jelölte ki:

\section{BÍRÁLÓ BIZOTTSÁG:}

\section{Elnöke:}

Simonné Sarkadi Lívia, DSc, BCE

\section{Tagjai:}

Lőrincz György, PhD, St. Andrea Borászat

Urbán András, PhD, MBOSZ

Kocsis László, DSc, PE

Dernovics Mihály, $\mathrm{PhD}, \mathrm{BCE}$

Opponensek:

Barócsi Zoltán, PhD, SZIE

Nyúlné Pühra Beáta, PhD, Nyakas Pincészet

Titkár:

Leskó Annamária, $\mathrm{PhD}, \mathrm{BCE}$ 


\section{Tartalom}

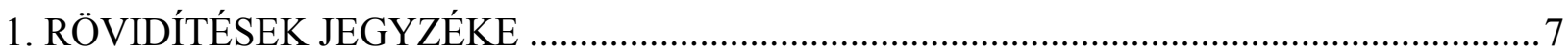

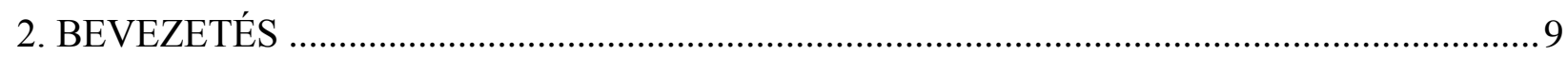

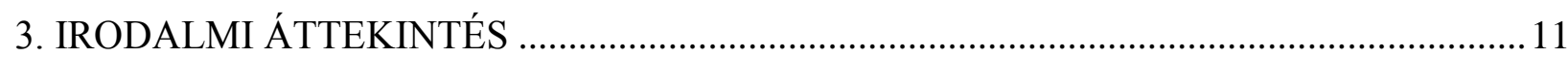

3.1. Alapanalitikai mutatószámok a szőlőben és a borban........................................................11

3.2. Élettanilag aktív vegyületek a szőlöben és a borban........................................................ 19

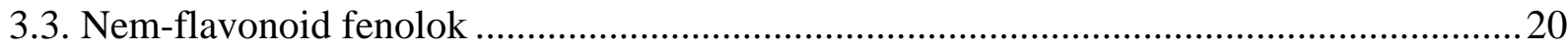

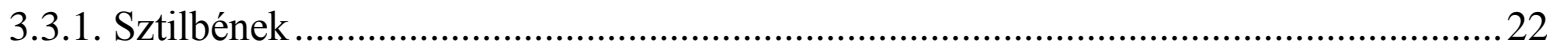

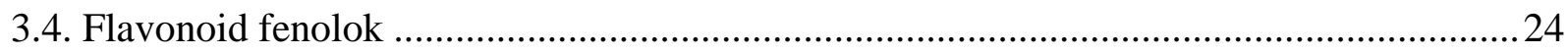

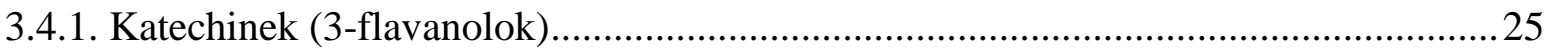

3.4.2. Katechinek szerepe a bor érzékszervi tulajdonságaiban .............................................26

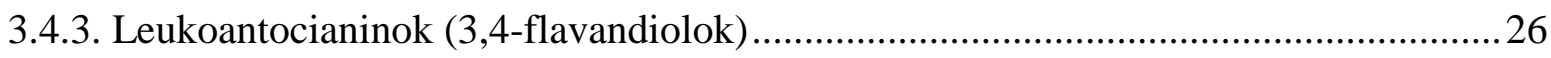

3.4.4. A katechinek és leukoantocianinok polimerizált származékai......................................27

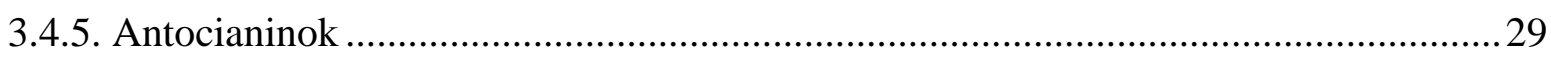

3.5. A bor minőségét befolyásoló tényezők ………………………………………………........ 34

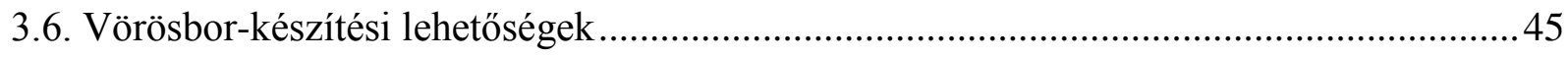

3.7. A fenolos vegyületek szerepe a borkészités és az érlelés során ...........................................53

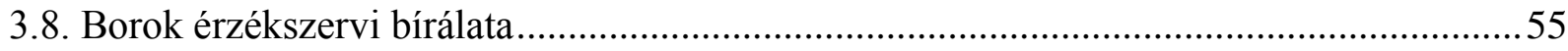

3.8.1. Az ízérzékelés szerepe a borok érzékszervi bírálatában .............................................59

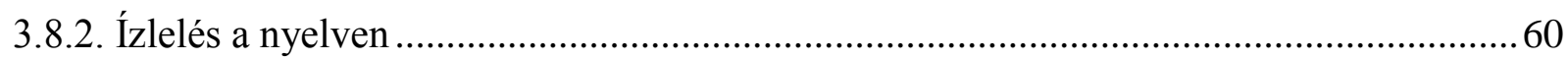

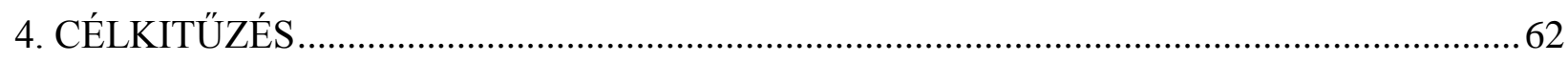

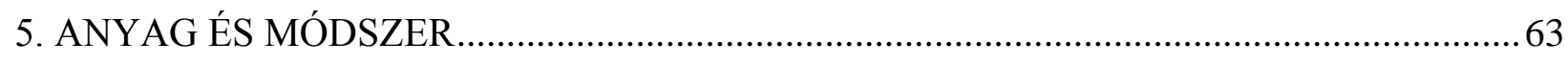

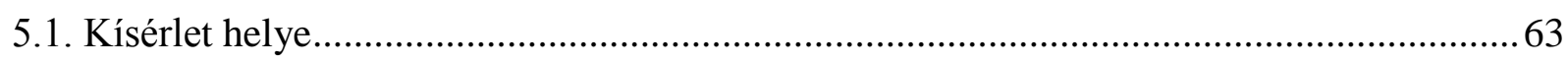

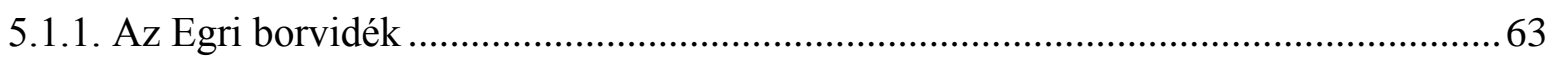

5.1.2. KRF Szőlészeti és Borászati Kutatóintézete, Eger......................................................... 63

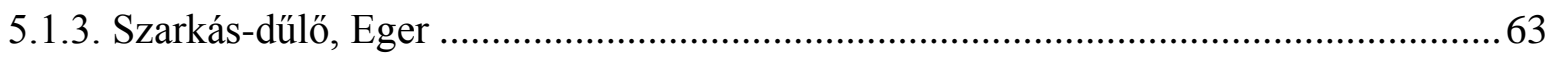

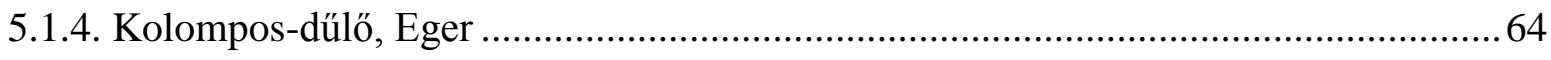

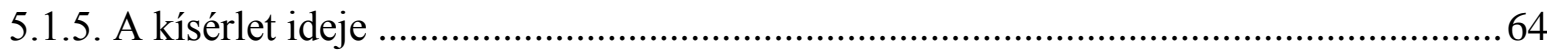




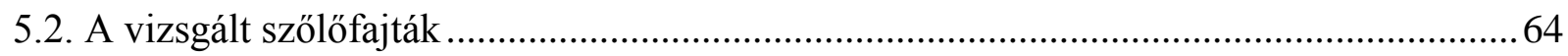

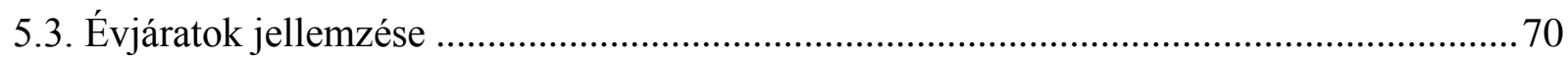

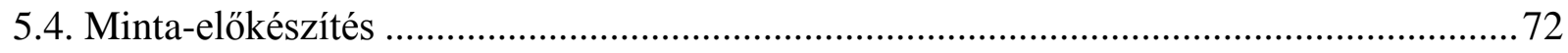

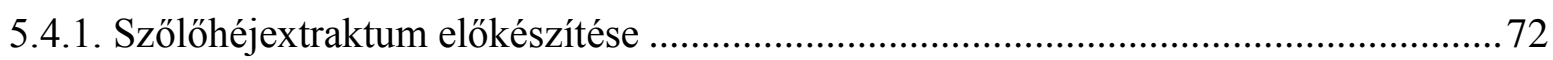

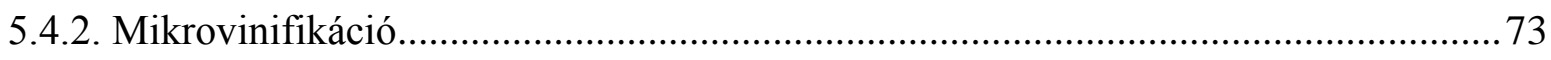

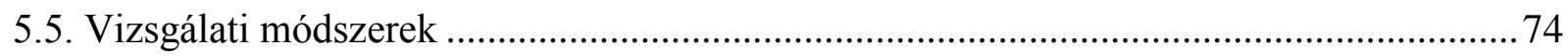

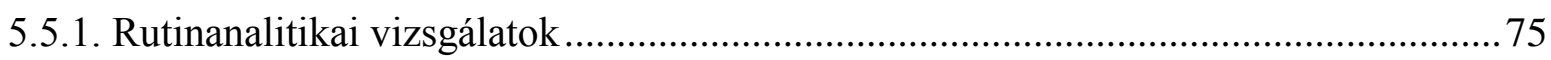

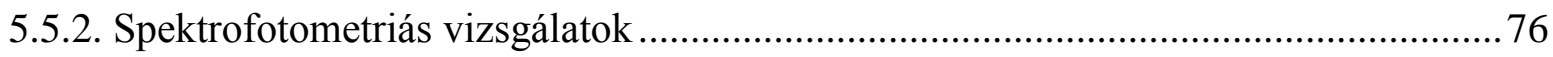

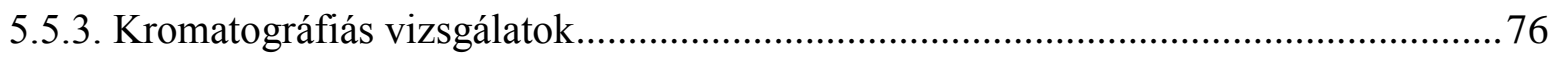

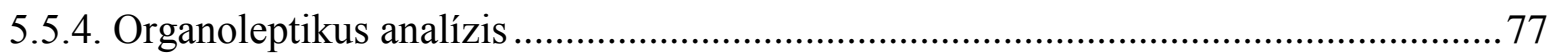

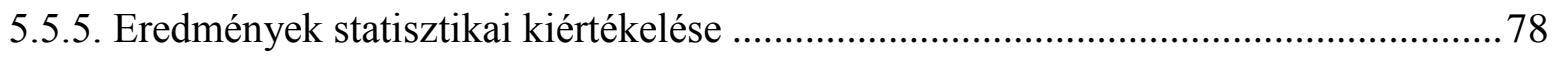

6. EREDMÉNYEK ÉS ÉRTÉKELÉSÜK …................................................................... 79

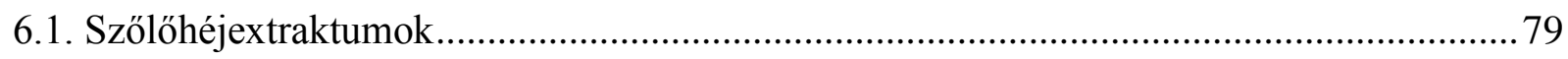

6.1.1.Szőlőhéj extraktumok vizsgálata 2007-ben........................................................ 82

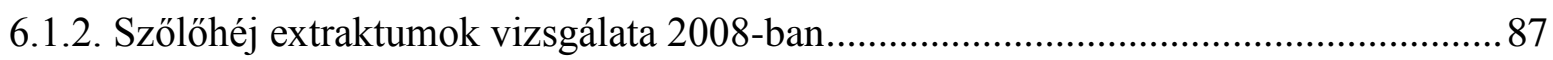

6.1.3. Szőlőhéjextraktumok vizsgálata 2009-ben....................................................... 92

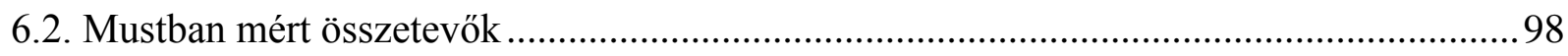

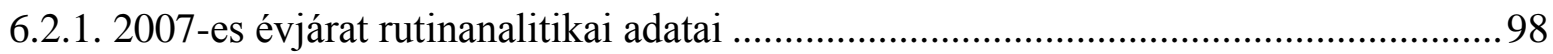

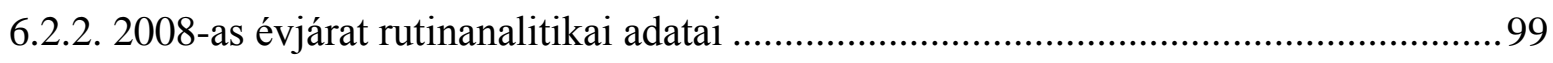

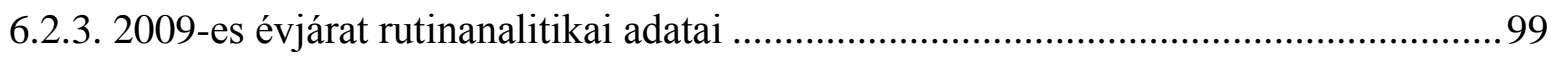

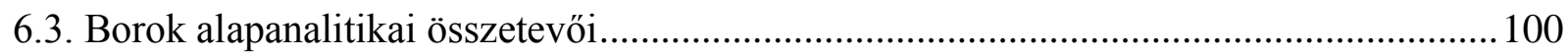

6.3.1. A 2007-es évjárat borainak rutinanalitikai eredményei ....................................... 101

6.3.2. 2008-as évjárat borainak rutinanalitikai eredményei .......................................... 102

6.3.3. 2009-es évjárat borainak rutinanalitikai eredményei .......................................... 102

6.4. Borok fenolos komponenseinek vizsgálati értékei .................................................... 104

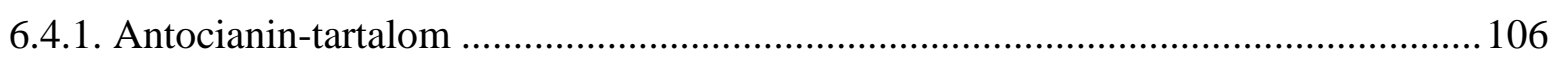

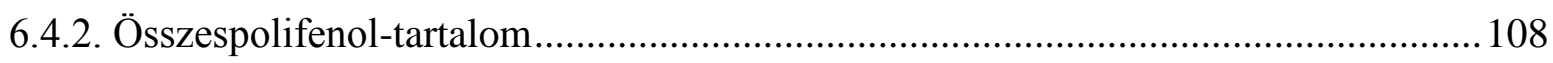

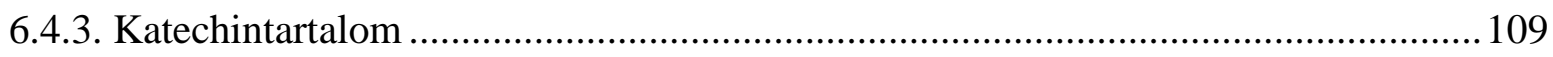




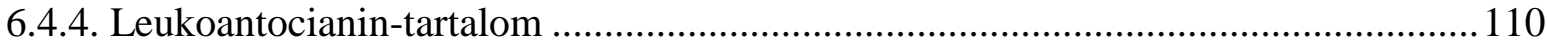

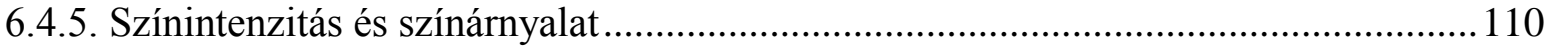

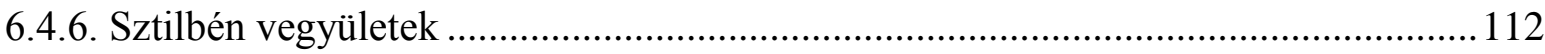

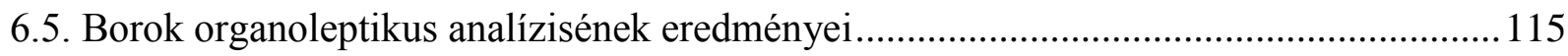

6.5.1. Az érlelés hatása a 2007-es Egri Bikavér érzékszervi tulajdonságaira ....................119

6.5.2. Az érlelés hatása a 2008-as Egri Bikavér érzékszervi tulajdonságaira ..................... 120

6.5.3. Az érlelés hatása a 2009-es Egri Bikavér érzékszervi tulajdonságaira .................... 120

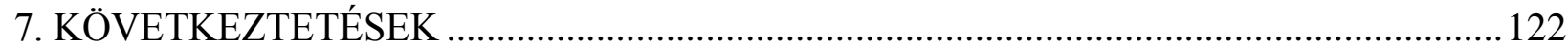

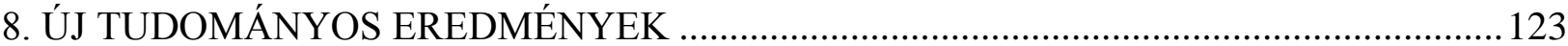

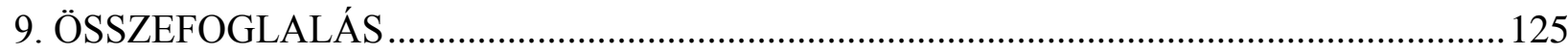

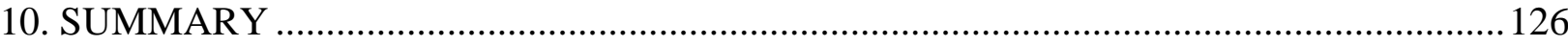

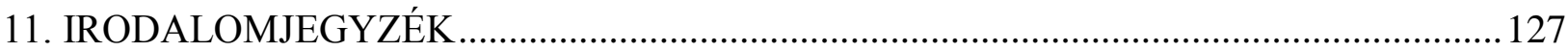

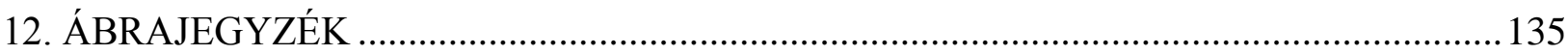

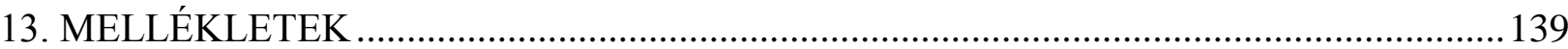




\section{RÖVIDÍTÉSEK JEGYZÉKE}

\section{SZÖLŐFAJTÁK}

\begin{tabular}{ll} 
BLAU. VÁLL & Blauburger - váll \\
BLAU. TEST & Blauburger - test \\
BLAU. VÉG & Blauburger - vég \\
KF. VÁLL & Kékfrankos - váll \\
KF. TEST & Kékfrankos - test \\
KF. VÉG & Kékfrankos - vég \\
ZW. VÁLL & Zweigelt - váll \\
ZW. TEST & Zweigelt - test \\
ZW. VÉG & Zweigelt - vég \\
\hline PN. VÁLL & Pinot noir - váll \\
PN. TEST & Pinot noir - test \\
PN. VÉG & Pinot noir - vég \\
ME. VÁLL & Merlot - váll \\
ME. TEST & Merlot - test \\
ME. VÉG & Merlot - vég \\
CF. VÁLL & Cabernet franc - váll \\
CF. TEST & Cabernet franc - test \\
CF. VÉG & Cabernet franc - vég \\
\hline TU. VÁLL & Turán - váll \\
TU. TEST & Turán - test \\
TU. VÉG & Turán - vég \\
BK. VÁLL & Bíbor kadarka - váll \\
BK. TEST & Bíbor kadarka - test \\
BK. VÉG & Bíbor kadarka - vég \\
SY. VÁLL & Syrah - váll \\
SY. TEST & Syrah - test \\
SY. VÉG & Syrah - vég \\
& \\
\hline
\end{tabular}

\section{BOROK}

$\begin{array}{ll}\text { KM } & \text { Kékmedoc/Menoire } \\ \text { BLAU } & \text { Blauburger } \\ \text { KO } & \text { Kékoportó/ Portugieser } \\ \text { PN } & \text { Pinot noir } \\ \text { ZW } & \text { Zweigelt } \\ \text { KAD } & \text { Kadarka } \\ \text { CF } & \text { Cabernet franc } \\ \text { CS } & \text { Cabernet Sauvignon } \\ \text { ME } & \text { Merlot } \\ \text { KF } & \text { Kékfrankos } \\ \text { TU } & \text { Turán } \\ \text { BK } & \text { Bíbor kadarka } \\ \text { SY } & \text { Syrah } \\ \text { BIKA } & \text { Bikavér }\end{array}$




\section{VEGYÜLETNEVEK}

ANT.

Ö.POL.

KAT.

LEUK.

T-P.

T-R.

C-P.

C-R.

SZI.

SZÁ.

ÉRZÉKSZERVI PARAMÉTEREK

SZV

SZB

ILLINT

ILLM

ILLGY

ILLFÜ

ILLFAJT

ILLID

ÍS

ÍH

IK

ÍGY

ÍM

IIID

ÍHA
Antocianin

Összes polifenol

Katechin

Leukoantocianin

Transz-piceid

Transz-rezveratrol

Cisz-piceid

Cisz-rezveratrol

Színintenzitás

Színárnyalat

Szín - vörös

Szín - barna

Illat - intenzitás

Illat - minöség

Illat - gyümölcsösség

Illat - füszeresség

Illat - fajtajelleg

Illat - idegen illat

Íz - savasság

Íz - húzósság

Íz - keserüség

Íz - gyümölcsösség

Íz - minőség

Íz - idegen íz

Íz - harmónia 


\section{BEVEZETÉS}

Hazánkban az Egri Bikavér az egyik legismertebb vörösbor. Több mint húszéves múltra vezethető vissza az Egri Bikavér újkori fogalmának meghatározása, mely a következő kérdésköröket elemezte: miben lehet más az Egri Bikavér a világ többi vörösbor-házasításaitól, a házasítás alkotóelemeként milyen fajták szerepelhetnek benne, illetve milyen borászati technológiákat alkalmazhatnak. Ekkor újrafogalmazódott az Egri Bikavér készítésének szabályzata, és 1997-ben az Egri Bikavér eredetvédelemben részesült.

Az utóbbi években a Bikavér minőségének javítása az Egri Hegyközség, illetve az egri termelők számára elsődleges célként jelent meg. Az Egri Bikavér és az Egri Bikavér Superior borok szőlőtermesztésének és borkészítésnek szabályozását a földmüvelésügyi és vidékfejlesztési miniszter az FVM 130/2003 XII. 31. számú rendeletében jogszabályként határozta meg, melyet először a 102/2009 VII.5. FVM rendeletben, majd pedig a 61/2010. V.11. rendeletben módosítottak. A jelenlegi szabályozás értelmében csak az a bor kerülhet Egri Bikavér néven forgalomba, amely az Egri borvidék meghatározott termőhelyeiről származik és a Hegyközség által rögzített szőlészeti és borászati előírásoknak megfelel. A szabályozások és a törekvések (melyben a minőségi borkészítés áll a középpontban) hatására a hazai és külföldi piacon az Egri Bikavér megítélése javuló tendenciát mutat. A fogyasztók körében ugyanakkor a mai napig nehezen határozható meg az Egri Bikavér fogalma, ugyanis mind árban, mind pedig minőségben széles paletta tárul eléjük.

A minőségi borok iránti kereslet növekedése, valamint a harmadik világ versenyképes borainak megjelenése a hazai piacon szinte megköveteli az Egri Bikavér szőlőfajtáinak, illetve a belölük készült borok mélyreható kémiai és organoleptikus tulajdonságainak feltérképezését, mivel ezen tényezők ismerete lehetővé teszi az Egri Bikavér készítés technológiájának optimalizálását. A minőségfejlesztés elérésével a szőlő- és borgazdaságban új lehetőségek nyílhatnak az Egri Bikavér számára, illetve méltán viselheti a zászlós bor szerepét az Egri borvidéken.

A kutatók több szempontból is vizsgálták a vörösborok, valamint az Egri Bikavér minőségfejlesztésének lehetőségeit, mégis szükség van célirányos, szisztemizáló kutatásra a termelés biztonsága, illetve az Egri Bikavér részletes megismerése és tökéletesítése céljából. 
Kutatómunkám releváns célja volt az Egri Bikavért adó szőlőfajták finomösszetételének vizsgálata, különös tekintettel a mennyiség korlátozásainak kutatására, valamint a Bikavért adó szőlőfajtákból készült borok, továbbá a házasított borok élettanilag aktív vegyületeinek vizsgálata, mind mennyiségi, mind minőségi szempontból.

Értekezésem során a házasítás és az érlelés hatásait tanulmányoztam, mely technológiai elemek az analitikai paramétereken kívül nagymértékben befolyásolják és hatást gyakorolnak a bor élvezeti, azaz organoleptikus értékeire. 


\section{IRODALMI ÁTTEKINTÉS}

\subsection{Alapanalitikai mutatószámok a szőlőben és a borban \\ Szerves savak}

A szerves savak nagymértékben hozzájárulnak a must és a bor savas tulajdonságához: lényeges elemei a bornak, a bor organoleptikus minőségének. Nagy szerepet játszanak a stabilitásban és különböző borbetegségek kialakulásában. A fehérborok magasabb savtartalma általában jobb érlelési potenciált eredményez. A vörösborok alacsonyabb savtartalommal is képesek stabilak maradni, ugyanis a fenolos vegyületek jelenléte is befolyásolja a pH-t, valamint természetes antioxidánsként segítenek fenntartani a vörösborok stabilitását az érlelés közben.

A must és a bor szerves savai egy vagy több királis centrummal rendelkeznek. A szerves savak molekulái részint szabad, részint kötött, vagy félig kötött állapotban vannak jelen. A savak minősége és mennyisége szabályozza a sav-bázis egyensúlyt, ezen keresztül a must és a bor savas ízét, melyet a szabad, vagy félig kötött savak okoznak. A must szerves savait alapvetően a borkősav, almasav és citromsav teszik ki. Glikolsav és glicerinsav, valamint kis mennyiségben oxálsav is van a szőlöben és mustban kristályos kalciumsó formájában. Több savbázisegyensúlyvizsgálat mutatott ki más szerves savakat is, de ezek nem játszanak fontos szerepet a must és a bor életében.

A bor legfontosabb szerves savai: borkősav, almasav, citromsav, tejsav, borostyánkősav és ecetsav. Az első három sav a szőlőből származik, a többi az alkoholos erjedés, érlelés és bakteriális tevékenység hatására keletkezhet. Emellett számos más szerves sav is kimutatható kis mennyiségben a borokban: a Botrytis cinerea hatására keletkező glükonsav és glükuronsav jelenléte bizonyítja, hogy a bor nemesrothadáson ment keresztül. A sikiminsav alciklikus vázú szerves sav, fontos biokémiai intermedier. Prekurzora az aromás aminosavaknak, cserzőanyagoknak, flavonoidoknak. Koncentrációja nagymértékben függ a termesztéstechnológiai eljárásoktól. A sikiminsav a kvercetinnel együtt pozitív élettani hatással rendelkezik fehérborokban (BERTELLI et al., 2008).

\section{Borkősav $(\mathrm{COOH}-\mathrm{CHOH}-\mathrm{CHOH}-\mathrm{COOH})$}

Kétbázisú oxisav, két aszimmetrikus szénatomja van. Optikailag két aktív izomerje van: a jobbra forgató L-borkősav és a balra forgató D-borkősav. A szőlőben és a mustban az L(+)-borkősav van jelen, mely színtelen, szagtalan, monoklin prizmákban kristályosodik. Alkoholban és vízben jól oldódik. A szőlö minden részében megtalálható. Az éretlen szőlőnek és mustnak uralkodó 
sava. A vegetatív ciklus végére az éretlen szőlő borkősav-koncentrációja $15 \mathrm{~g} / \mathrm{L}$ is lehet. Az északi bortermő vidékeken a borkősavtartalom a $6 \mathrm{~g} / \mathrm{L}$ koncentrációt is meghaladhatja, a délebbi területeken a magasabb hőmérséklet hatására alacsonyabb értékekre számíthatunk: 2-4 g/L-re. A természetben a borkősav nem elterjedt szerves sav, ez az oka annak, hogy Németországban „Weinsäure”-nak is, azaz „borsavnak” nevezik (RIBÉREAU-GAYON et al., 2006). Sói közül a borászati szempontból fontos a félig kötött káliumsója, a borkő (kálium-hidrogén-tartarát) és a kötött, semleges kalciumsója. A borkő vízben és alkoholban rosszul oldódik, ennek következményeképpen az erjedés során kiválik, így a kötött borkősav mennyisége csökken. A borkövet számos iparág felhasználja: ital- és élelmiszeripar, gyógyászat és a festékipar. A borkősav származékát, a tartrazint a sárga színhatása miatt a gyapjú és selyemiparágban, valamit élelmiszerfestékként alkalmazzák.<smiles>O=C(O)C(O)C(O)C(=O)O</smiles><smiles>O=C(O)C(O)C(O)C(=O)O</smiles>

1. ábra: $\mathrm{L}(+)$-borkősav és a $\mathrm{D}(-)$-borkősav szerkezeti képlete

\section{$\underline{\text { Almasav }}\left(\mathrm{COOH}-\mathrm{CHOH}-\mathrm{CH}_{2}-\mathrm{COOH}\right)$}

Kétbázisú oxisav, egy aszimmetrikus szénatomja van, optikailag két aktív izomerje: a Dalmasav, valamit az L-almasav. A szőlőben és a mustban az L(-)-almasav fordul elő, forgatóképessége a töménységgel csökken, 34\%-osnál töményebb oldata már jobbra forgat. Az almasav szétfolyó tűkristályokat képez, vízben és alkoholban egyaránt jól oldódik. Az élő szervezetekben széles körben elterjedt. Főként a zöldalmában található meg nagy koncentrációban, ez magyarázza, hogy a németeknél „Apfelsäure”-nak, vagy „alma savának” nevezik. Ezen kívül jelen van a fehér és piros ribizliben és a rebarbarában is. A zöld szőlőkben a színesedés előtt $25 \mathrm{~g} / \mathrm{L}$ mennyiségben is előfordulhat. Két héttel a színesedést követően mennyisége a felére csökkenhet, mely a bogyók növekedésével hozható párhuzamba, ugyanis ezt a hígulás és az almasav légzésben való felhasználása eredményezi. A hüvösebb fekvésü területeken az érés során a must 4-5 g/L almasavat tartalmazhat, míg délebbre 1-2 g/L koncentrációt (RIBÉREAU-GAYON et al., 2006). 


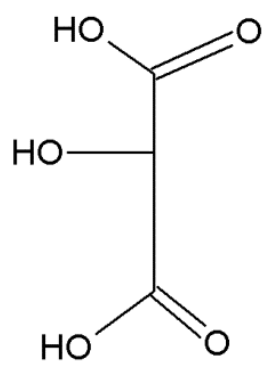

2. ábra: Almasav szerkezeti képlete

\section{Citromsav $\left(\mathrm{C}_{6} \mathrm{H}_{8} \mathrm{O}_{7}\right)$}

Színtelen, akirális vegyület, hárombázisú oxisav. Vízben és alkoholban jól oldódik. A természetben széles körben fordul. Az élesztők tevékenységét lassítja, de nem blokkolja (KALATHENOS et al.,1995). Gyakorlati szempontból fontos vegyület, sok iparág hasznosítja. A szőlőben és a mustban igen csekély; 0,5 és $1 \mathrm{~g} / \mathrm{L}$ mennyiségben fordul elő (RIBÉREAUGAYON et al., 2006).

\section{$\underline{\text { Tejsav }}\left(\mathrm{CH}_{3}-\mathrm{CHOH}-\mathrm{COOH}\right)$}

Egy aszimmetrikus szénatomot tartalmazó királis vegyület, optikailag aktív. Vízben, alkoholban jól oldódik. Három módosulata van: a balra forgató D-tejsav, a jobbra forgató L-tejsav és egy optikailag inaktív tejsav. A borban a két optikailag aktív tejsav keveréke található. A D(-)-tejsav cukorból képződik alkoholos erjedés során, míg az L(+)-tejsav almasavból a malolaktikus fermentáció alatt. Minden bor természetes alkotórésze. Tejsav képződhet még baktériumos tevékenység hatására is. Mennyisége a borban folyamatosan növekszik, kivételt képeznek a folyamatosan kénezett borok, ugyanis a kénessavtartalom az almasavbomlást és a baktériumos folyamatokat is gátolja, így az érlelés során változatlan marad a tejsavtartalom, $\mathrm{kb} .1 \mathrm{~g} / \mathrm{L}$ koncentrációban (KÁLLAY, 2010).

\section{Borostyánkősav $\left(\mathrm{COOH}-\mathrm{CH}_{2}-\mathrm{CH}_{2}-\mathrm{COOH}\right)$}

Négy szénatomos, kétbázisú szerves sav. Vízben és alkoholban jól oldódik. Aszimmetrikus szénatomja nincs, így optikai forgatóképességgel nem rendelkezik. Az élesztők tevékenysége során képződik, az alkoholos erjedés másodlagos terméke. Mennyisége a borokban átlagosan 1 g/L koncentráció. Ezt a szerves savat az összes élő szervezet termeli, részt vesz a lipidek metabolizmusában és a fumársavval együtt a Krebs-ciklusban is. A borostyánkősav intenzíven keserü, emellett sós ízvilággal is rendelkezik. Ezekkel a zamatokkal kiemeli a bor aromáit és közrejátszik a boríz kialakulásában (PEYNAUD, BLOUIN, 1996). 


\section{Ecetsav $\left(\mathrm{CH}_{3}-\mathrm{COOH}\right)$}

Szúrós szagú, színtelen folyadék. Vízzel, alkohollal és éterrel korlátlanul keveredik. Ecetsav egészséges mustokban nyomokban fedezhető fel, míg rothadó, penészes mustokban nagyobb mennyiségben is előfordulhat. Az ecetsav képződése a cukortartalommal hozható összefüggésbe: nagyobb cukortartalmú mustoknál több ecetsav képződik. Bizonyos élesztőfajtáknál nagyobb ecetsav-termelödés figyelhető meg. A malolaktikus fermentáció során is keletkezik kis mennyiségű ecetsav, mely főleg a citromsav lebomlásából származik. A borok érlelése során gondos kezelés mellett az ecetsavtartalom változatlan marad. A bor egészségesnek tekinthető, ha az ecetsav-koncentráció nem haladja meg a 0,8-1 g/L-t.

A borokban egyéb illósavak is jelen lehetnek, mennyiségük baktériumos elváltozások során emelkedhet. A hangyasav, a leucinbomlás terméke; propinsav, anaerob baktériumok által megtámadott boroknál fordul elő; tejsav, tejsavas erjedésű boroknál nagyobb mennyiségben mutatkozik.

\section{Szénhidrátok}

A szénhidrátok a növények által fotoszintézis során termelt szén-, oxigén- és hidrogéntartalmú szerves vegyületek. A növényekben tartaléktápanyagok és vázanyagok. A szénhidrátok polifunkcionális molekulákat tartalmaznak, ezáltal képesek részt venni nagyszámú kémiai, biokémiai és metabolikus reakcióban. A szénhidrátok prekurzorai a szerves savaknak. A glikolízisen keresztül a glükóz prekurzora a citromsavnak, almasavnak és borostyánkősavnak, valamint a pentóz-csatornán keresztül a borkősavnak és sikiminsavnak. A szénhidrátok a fenolos vegyületek, illetve az aromás aminosavak, mint például a tirozin, a fenilalanin és a triptofán prekurzorjai (RIBEREAU et al., 2006). A must túlnyomó részét a glükóz és fruktóz, azaz a redukáló cukrok teszik ki. A glükóz- és fruktóz-koncentráció érett szőlőmustban 150 és 250 g/L között változik. A túlérett, töppedt vagy nemes rothadáson átesett szőlő redukáló cukortartalma ennél magasabb is lehet. A botritiszes szőlők mustjában jellemző az oxo-5-fruktóz, mely a kéndioxiddal lép reakcióba (BARBE et al., 2001).

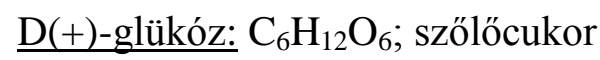

Dextróz, ugyanis a fény poláris síkját jobbra forgatja, $(\alpha)=+52,5^{\circ}$. Aldehidcukor, mivel egy aldehidcsoportot tartalmaz, a karbonilcsoport mindig a lánc végén található, könnyen oxidálható. Savas és enzimes lebontással nem bontható egyszerübb cukrokká. Az élesztő közvetlenül erjeszti alkohollá és szén-dioxiddá. Az érett szőlőből készült must glükóztartalma a fruktózzal közel 
azonos, viszont már a G/F-arány az erjedésben megváltozik, ugyanis az élesztők a glükóztartalmat szinte teljesen kierjesztik.

D(-)-fruktóz: $\mathrm{C}_{6} \mathrm{H}_{12} \mathrm{O}_{6}$; gyümölcscukor

Levulóz, mert a fény poláris síkját balra forgatja, $(\alpha)=-93,0^{\circ}$. Ketoncukor, mivel egy ketoncsoportot tartalmaz, a karbonilcsoport a második szénatomon van. Vízben oldva, a D(+)glükózhoz hasonlóan, zárt szénláncú formává alakul át, amely piránszármazéknak tekinthető, melynek két sztereoizemerje van ( $\alpha$ és $\beta$ ). Az élesztő közvetlenül erjeszti alkohollá és széndioxiddá. A mustban található fruktóz mennyisége a szőlőfajtától, évjárattól, érési állapottól függően széles határok között mozog: 70-120 g/L között változik (KÁLLAY, 2010).
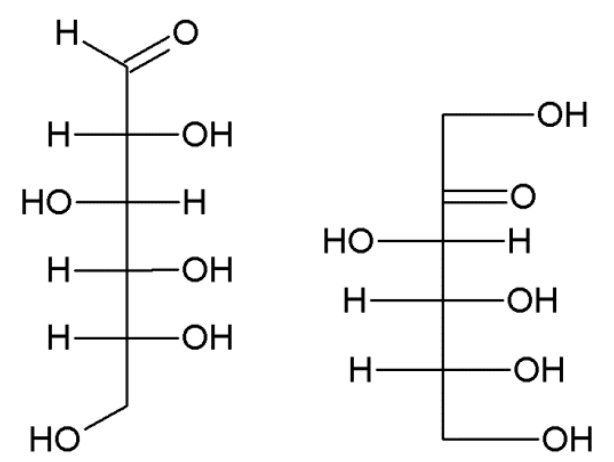

3. ábra: $\mathrm{D}(+)$-glükóz és $\mathrm{D}(-)$-fruktóz szerkezeti képlete

Pentózok: $\mathrm{C}_{5} \mathrm{H}_{10} \mathrm{O}_{5}$

Öt szénatomos monoszacharidok. A hexózokkal ellentétben az élesztő nem erjeszti őket, a tejsavbaktériumok igen, viszont a Fehling-oldatot redukálják. Kristályosodnak, híg savvakkal desztillálva furfurollá alakulnak. A mustokban mindig megtalálhatóak (L-arabinóz, D-xilóz) kisebb mennyiségben: 0,3-1,2 g/L. Mivel nem erjeszthetőek, ezért a borban is detektálhatóak. Az arabinózt tejsavbaktériumok megtámadják, így mennyisége csökkenhet a borban a mustállapothoz képest.

Szacharóz: $\mathrm{C}_{12} \mathrm{H}_{22} \mathrm{O}_{11}$; nádcukor, répacukor

Diszacharid, a glükóz és fruktóz anhidridje. Hidrolízise a következő:

$$
\begin{array}{lllll}
\mathrm{C}_{12} \mathrm{H}_{22} \mathrm{O}_{11}+\mathrm{H}_{2} \mathrm{O} & \rightarrow & \mathrm{C}_{6} \mathrm{H}_{12} \mathrm{O}_{6} & + & \mathrm{C}_{6} \mathrm{H}_{12} \mathrm{O}_{6} \\
\text { szacharóz } & & \text { glükóz } & + & \text { fruktóz }
\end{array}
$$

A szacharóznak nincs sem aldehidje, sem ketoncsoportja. Optikailag aktív, jobbra forgat $(\alpha)_{D}=+$ 66,5․ Az élesztők közvetlenül nem erjesztik, csak hidrolízis után. Híg savak, vagy enzimek 
hatására hidrolizál, vízkilépés mellett glükóz és fruktóz keletkezik belöle, ennek egyenlő mennyiségű elegyét nevezik invertcukornak. A szacharóz gyors felhasználásra szolgáló cukortartaléka a növénynek, a szőlő leveleiben és zöld részeiben található meg. A levéltől a gyümölcsig invertálódik. Az érett bogyókban már csak nyomokban található meg (1-3 g/L). Magyarországon termett szőlőkben és mustokban szacharózt nem, vagy csak nyomokban mutattak ki (KÁLLAY, 2010).

$\underline{\text { Poliszacharidok }}$

Nagy molekulájú szénhidrátok: sok szőlőcukor-molekula vízkilépéssel kapcsolódik össze és poliszacharid keletkezik. Hidrolízissel egyszerü cukrokká bonthatók, több száz, vagy ezer cukormolekulából épülnek fel. Vízben nem oldódnak, nem édes ízűek, sok tulajdonságuk nem cukorszerü. A növények sejtjeiben találhatóak meg. Főbb poliszacharidok a keményítő és cellulóz. A keményítő a növény tartalék tápanyaga. Cukorrá bontva vándorol a növényben, a vándorlás alatt egyes helyeken újból keményítővé alakul. Az érett bogyó keményítőt nem, vagy csak nyomokban tartalmaz. A poliszacharidok jelenlétének két fó forrásavan a szőlőben. Az egyik, mikor a szőlő Botrytis cinerea-fertőzésen ment keresztül, ugyanis a gomba poliszacharidokat termel, mely a későbbiekben, a borban is kimutathatóvá válhat. A másik lehetőség a Pediococcus baktérium, mely képes poliszacharid-termelésre, ettől a bor nyálkássá, nyúlóssá válik. A szőlőbogyó tartalmaz pektinanyagokat, melyek a borászat szempontjából fontosak. Stabilizálják a kolloidos zavarosodásokat, ezáltal a szőlő nehezen préselhetővé, a must pedig nehezen kezelhetővé válik.

A szénhidrátoknak jelentős szerepe van a borok organoleptikus megítélésében. 3-4 g/L mennyiségben már érzékszervileg érezhető ízűek, befolyásolják a savak érzékszervi hatását. A borok édességének érzetét a cukor fajtája is befolyásolja, nemcsak a mennyisége. Más édességi érzetet keltenek és más az úgynevezett cukorértékük. Ha a szacharóz cukorértéke 1, akkor a glükóz cukorértéke 0,74, a fruktózé 1,73, a pentózoké 0,40. Mindent összevetve azonos redukáló cukortartalomnál a bor édességi érzete függ a G/F-aránytól.

\section{Alkoholok}

Egy, vagy több hidroxilcsoportot tartalmazó szerves vegyület. Az alkoholokban a hidroxilcsoport telített szénhidrogénhez kapcsolódik. Az összes alkohol jól oldódik etanolban és éterben. 


\section{Etil-alkohol: $\mathrm{CH}_{3}-\mathrm{CH}_{2}-\mathrm{OH}$}

Színtelen, jellegzetes ízü, gyenge illatú folyadék. Vízzel minden arányban keveredik, és sok szerves anyag oldószere. A vízen kívül a bor egyik legfontosabb alkotórésze, természetes védőés tartósító anyaga. A bor erősségét az alkoholtartalom fejezi ki. Ha az etanol sürüsége $79 \mathrm{~g} / \mathrm{L}$, akkor a bor $10 \mathrm{~V} / \mathrm{V} \%$-os alkoholtartalommal rendelkezik. Általában a borok erőssége $100 \mathrm{~g} / \mathrm{L}$, azaz 12,6 V/V\%. Az etil-alkohol az alkoholos fermentáció során keletkezik cukorból. Körülbelül $18 \mathrm{~g} / \mathrm{L}$ cukor szükséges $1 \mathrm{~V} / \mathrm{V} \%$ alkohol előállításához. Ha a must cukortartalma 180, 226 és 288 g/L, akkor abból 10, 12,6 és 16 V/V\%-os alkoholtartalom keletkezik (RIBÉREAU-GAYON et al., 2006).

A képződő alkohol mennyisége függ az élesztőfajtáktól, ugyanis a nagyobb cukortartalmú mustokat az élesztők általában nem tudják bizonyos alkoholfokon felül erjeszteni. A bor alkoholtartalma közvetlenül függ a klimatikus tényezőktől. Nagy alkoholfokok bizonyos évjáratokban keletkeznek, mikor a termesztéstechnológiai feltételek megfelelőek, jó a szőlöültetvény kitettsége, és magas a napsütötte órák száma. Kiemelkedő évjáratok borai szinte mindig nagy alkoholtartalmúak. A nagyobb alkoholtartalmú bor jobban ellenáll a mikroorganizmusok okozta borbetegségeknek. Fertőtlenítő tulajdonsága végett hosszabb érlelést és eltarthatóságot biztosít a boroknak. Bizonyos borkésztési eljárásokban etanolt adnak a borhoz a stabilitás érdekében. Az alkohol a borban kémiailag stabil, de szerves savakkal és aldehidekkel észtereket és acetátokat képez, melyek közrejátszanak a bukéanyagok kialakulásában. Az etilalkoholt az ecetsav-baktériumok megtámadják és ecetsavvá oxidálják. Párolgás következtében kismértékü alkoholcsökkenés jelentkezhet, tehát a száraz borok alkoholtartalma lassan, de folyamatosan csökken.

\section{Metil-alkohol: $\mathrm{CH}_{3}-\mathrm{OH}$}

Sajátos szagú, vízzel és etil-alkohollal korlátlanul elegyedő folyadék. A borok mindig tartalmaznak metil-alkoholt 20-30 mg/L mennyiségben. Nincsen érzékszervi hatása. Ez a mennyiség a szőlőpektinek metoxicsoportjának erjedés alatti enzimes hidrolíziséből ered. Ha a szőlő viszonylag alacsonyabb pektintartalommal bír, akkor a borban is alacsonyabb metilalkohol-koncentráció lesz. A szőlő szilárd részei mindig több pektint tartalmaznak, így a törkölyön erjesztett borok magasabb metil-alkohol-tartalommal bírnak. A vörösborokban van a legmagasabb mennyiség: $152 \mathrm{mg} / \mathrm{L}$, majd a rozé borokban: $91 \mathrm{mg} / \mathrm{L}$, míg a fehérborokban 63 mg/L (RIBÉREAU-GAYON et al., 1982). 
A fajták szerint is van különbség, ugyanis a direkt termő borokban magasabb a metil-alkohol koncentráció, mint az európai szőlőkből származókban. Ha a préselés könnyítésére, vagy a must tisztítására pektinbontó enzimet alkalmazunk, akkor a borokban megnő a metil-alkohol mennyisége, ez a pektinészteráz aktivitás eredménye. A metil-alkohol köztudottan erősen mérgező hatású. Már 8-10 g metil-alkohol elfogyasztása látási zavarokat idézhet elő, 30-40 g pedig halálhoz is vezethet. Hazai vizsgálatok alapján a fehérborok metil-alkohol-tartalma 21117, a siller- és vörösborok 40-160, a direkt termő borok 40-293 mg/L között mozog (KÁLLAY, 2010).

Magasabb rendü alkoholok

Két szénatomnál többet tartalmazó egyértékü alkoholok, vagy más néven kozmaalkoholok, kozmaolajok. Ezek az alkoholos erjedéskor melléktermékként képződnek. Ide tartoznak egyes propil-, butil- és amilalkoholok. Mennyiségük a borokban 150-500 mg/L. A bor organoleptikus tulajdonságainak kialakításában nagy szerepük van. Szerves savakkal észtereket, aldehidekkel acetálokat képeznek, melyek kellemes illatú és aromájú vegyületek.

\section{Glicerin: $\mathrm{CH}_{2} \mathrm{OH}-\mathrm{CHOH}-\mathrm{CH}_{2} \mathrm{OH}$}

Háromértékű alkohol. Édes ízü, szagtalan, szirupszerü folyadék. Vízzel és alkohollal korlátlanul elegyedik. Az alkoholos erjedés másodlagos terméke. Az erjedés elején képződik a glicerin legnagyobb része. A képződött mennyiség függ a must cukortartalmától, az élesztő fajtájától, az erjedési hőmérséklettől, a savtartalomtól, az oxigén jelenlététől, a kénezés mértékétől. Az alkohol után a glicerin a bor legnagyobb mennyiségü alkotórésze, a bor extraktanyagainak jelentős részét képzi. Pozitív érzékszervi attribútumokkal ruházza fel a bort: lágyságot, simaságot, bársonyosságot, teltséget kölcsönöz. Mennyisége változó, a szőlő és a borkészítési eljárás befolyásolja mennyiségét. A glicerintartalom az érlelés folyamán csökkenhet, ha a tejsavbaktériumok megtámadják és lebontják.

Etilénglikol (EG): $\mathrm{HO}-\mathrm{CH}_{2}-\mathrm{CH}_{2}-\mathrm{OH}$

Borok természetes alkotórésze, L-szerinből képződik. Kétértékű alkohol, édeskés ízű, mérgező tulajdonságú. Az alacsony hőmérséklet és a vontatott erjedés elősegítheti képződését.

Dietilénglikol (DEG): $\mathrm{HO}-\mathrm{CH}_{2}-\mathrm{CH}_{2}-\mathrm{O}-\mathrm{CH}_{2}-\mathrm{CH}_{2}-\mathrm{OH}$

A bor nem természetes alkotórésze, jelenléte hamisításra utal. Mérgező vegyület. 1,2-propilénglikol (propándiol, PG) 
A bor természetes alkotórésze, nem mérgező. A borászatban ezt a vegyületet hűtőközegként alkalmazzák.

\section{2,3-butilénglikol (2,3-butándiol): $\mathrm{CH}_{3}-\mathrm{CHOH}-\mathrm{CHOH}-\mathrm{CH}_{3}$}

Kétértékű alkohol, az erjedés alatt képződik az acetoin redukciója által. Keserü-cukros ízű anyag, stabil szerkezetü, a glicerint erjesztő baktériumok nem támadják meg.

\section{$\underline{\text { Mezo-inozit }}$}

Hatértékű alkohol, a szőlőből származik. Mennyisége az erjedés alatt keveset csökken, hiszen nem erjeszthető. Az érlelés során a tejsavbaktériumok megtámadják, és részben vagy teljesen lebonthatják.

\section{Mannit: $\mathrm{CH}_{2} \mathrm{OH}-(\mathrm{CHOH})_{4}-\mathrm{CH}_{2} \mathrm{OH}$}

Hatértékü alkohol. Jelenléte a borban hibás erjedésre utal. Ha az erjedés hőmérséklete $35^{\circ} \mathrm{C}$ fölé emelkedik, az élesztők tevékenysége leáll, emiatt leáll az erjedés is. Az édesen maradt bor kedvező az anaerob baktériumok fejlődésének, melyek megtámadják a glükózt és fruktózt, melyböl tejsav, ecetsav és a fruktózból mannit keletkezik. Az alacsonyabb savtartalom még inkább kedvez a baktériumok tevékenységének. Ha az érlelés során az almasavbomlás elhúzódik, és a bor tartalmaz maradék cukrot, akkor a baktériumok megtámadják a ki nem erjedt cukrot, melyből mannit képződik (MAGYAR, 2010).

\section{Szorbit: $\mathrm{CH}_{2} \mathrm{OH}-(\mathrm{CHOH})_{4}-\mathrm{CH}_{2} \mathrm{OH}$}

Hatértékű alkohol, a mannit izomerje. Kis mennyisége a szőlőből ered. Magasabb koncentrációja a borban gyümölcsborokkal való házasításra, hamisításra mutat, ugyanis a gyümölcsborok természetes alkotórésze a szorbit (KÁLLAY, 2010).

\section{2. Élettanilag aktív vegyületek a szőlőben és a borban}

A minőségét, karaktert kardinálisan befolyásoló tényező a bor kémiai összetétele. A bor közel kétszáz szerves és szervetlen vegyületet tartalmaz, illetve azok kolloidos oldatát. Ezen vegyületek olykor néhány $\mu \mathrm{g} / \mathrm{L}$, vagy ennél kisebb mennyiségben vannak jelen, de mindegyik meghatározó szerepet játszik a bor attribútumainak kialakításában. Ezeknek a komponenseknek egy része már a szőlőben és a mustban is megtalálható, másik részük az alkoholos erjedés során képződik, illetve az érlelés hatására átalakul. A bor egy élő szervezet, az összetétele nem állandó, folyamatosan változik, fejlődik, vagy visszafejlődik. 
A szerves molekulák családjába tartoznak a fenolos vegyületek, melyek nagy mennyiségben fordulnak elő a szőlőben, mustban és borban. A fenolokhoz minden egyes olyan molekula tartozik, amelyben a benzolgyürühöz hidroxilcsoport kapcsolódik. A fenolok másodlagos anyagcseretermékei a növényeknek és fontos szerepet játszanak a borászatban, mint például a vörösborok színének kialakításában, a borok ízének formálásában és a borstabilitásban. A fenolos vegyületek pozitív humán élettani tulajdonságokkal is rendelkeznek.

Dolgozatom során a szőlő és bor élettanilag aktív vegyületein belül a fenolos összetétellel foglalkoztam, azok mennyiségi és minőségi jelenlétét vizsgáltam, illetve átalakulásukat követtem nyomon. PERI és POMPEI (1971) alapján a következő táblázat a fenolos vegyületek csoportosítását mutatja be.

1. táblázat: Fenolos vegyületek csoportosítása (PERI és POMPEI, 1971)

\section{NEM FLA VONOID}

\begin{tabular}{|c|c|c|}
\hline FENOLOK (EGYSZERÜ & FLAVONOID FENOLOK & TANNIN FENOLOK \\
\hline \multicolumn{3}{|l|}{ FENOLOK) } \\
\hline oxifahéjsav-származékok & katechin-monomerek & katechin-dimerek \\
\hline oxifahéjsav-észterek & katechin-galluszsav észterek & katechin-trimerek \\
\hline dihidroxi-benzoésavak & quercetin & katechin-oligomerek \\
\hline \multirow{2}{*}{$\begin{array}{l}\text { trihidroxi-benzoésavak } \\
\text { galluszsav éterjellegü }\end{array}$} & quercetin-glikozid & katechin-polimerek \\
\hline & leukoantocianidin-monomerek & leukoantocianidin-polimerek \\
\hline & antocianidin-monomerek & $\begin{array}{c}\text { antociandin-polimerek } \\
\text { procianidinek }\end{array}$ \\
\hline
\end{tabular}

\subsection{Nem-flavonoid fenolok}

A fenolos vegyületek fontos szerepet játszanak a borászatban. Ezek a vegyületek a szőlőfürt különböző részeiről származnak, majd a borkészítési folyamatok során extrahálódnak. A nemflavonoid fenolok, vagy egyszerü fenolok főként a bogyóhúsban lokalizálódnak észter típusú vegyületek formájában. Az egyszerü fenolokhoz a fenolsavak és a sztilbén vegyületcsoport tartozik. A fenolsavakat két csoportra osztjuk: benzoesav és származékai, illetve a hidroxifahéjsav és származékai. A szőlő és a bor hat benzoesav- és három fahéjsav- származékot tartalmaz. A fenolsavak kémiai összetételét a 4. ábra mutatja be (RIBÉREAU-GAYON et al., 2006). 
<smiles>[R]c1cc(C(=O)O)c([R2])c([R3])c1[R5]</smiles>

Benzosesav-származékok p-hidroxi-benzoesav protokatechusav vanillinsav galuszsav sziringinsav szalicilsav genzicinsav

$\begin{array}{ll}\mathrm{R}_{2} & \mathrm{R}_{3}\end{array}$

$\mathrm{H}$

$\mathrm{H}$

$\mathrm{H}$

$\mathrm{H}$

$\mathrm{H}$

$\mathrm{OH}$

$\mathrm{OH}$<smiles>[R5]c1cc(/C=C/C(=O)O)c([R2])c([R3])c1[R5]</smiles>

Fahéjsav-származékok

$p$-kumársav

kávésav

ferulasav

$\mathrm{OH}$

$\mathrm{OCH}_{3}$

szinapinsav

\section{4. ábra: Fenolsavak kémiai összetétele a szőlőben és a borban}

A benzoesav és származékai a szőlőben föként glikozidos formában, észter típusú vegyületként vannak jelen. CHIRA és munkatársai (2008) mérései alapján a szőlőben a benzoesav és származékai közül a galluszsavat 100-230 mg/kg értékben detektálták. A benzoesavszármazékok a glikozidos kötés hidrolízise, valamint az antocianinok hő hatására végbemenő lebomlásának következtében legföképp a vörösborokban szabad állapotban találhatóak meg (GALVIN, 1993). Eszerint a floroglucin mellett keletkezhet a peonidinből vanillinsav, a cianidinből protokatechusav, a delfinidinből galluszsav (KÁLLAY, 2010).

A fahéjsavszármazékok szabad állapotban kis mennyiségben azonosíthatóak, viszont észterezett alakban, különösen a borkősavval alkotott vegyületek formájában találhatóak meg (RIBÉREAUGAYON, 1963). A borkősavval alkotott észtervegyületek, amelyek közül a kaftársav és kutársav kedvelt szubsztrátjai a szőlő polifenol-oxidáz enzimeinek, melyek a mustban oxidálhatóbb komponensekké válnak, ezáltal barnulást okozhatnak (CHEYNIER et al., 1989a, 1989b). A fahéjsav származékok az antocianinokkal alkotott vegyületek (acilezett antocianinok) formájában is megtalálhatóak. Organoleptikus aspektusból tekintve kevésbé érezhető vegyületek, főképp az illat szempontjából, viszont prekurzorjai az illékony fenoloknak, úgy, mint az etilfenol, vagy etil-guajakol, melyek illat- és ízhibát okozhatnak. Ezek a vegyületek föként a pkumársav és ferulasav degradációjából származnak (CHATONNET, 1995).

A fenolsavak vizes-alkoholos oldatban színtelenek, oxidálva sárga színárnyalatot vehetnek fel. Érzékszervi szempontból színtelenek, szagtalanok. Különböző mikroorganizmusok (föleg 
Brettanomyces élesztők) azonban illó fenolokká alakíthatják őket. Az etil-fenol, melyet animális illat jellemez, illetve az etil-guajakol a vöröborokban fordul elő. Illó fenolok képződnek és kerülnek át a borba a barrik hordós érlelés során a lignin-lebomlás következtében. A guajakol, a metil-guajakol, a propil-guajakol, az allil-guajakol, a sziringol és a metil-sziringol szerepet játszik a jellegzetes barrik illat és íz kialakulásában, úgy, mint a füstös, égett és pirított aromákban. A tirozol, vagy más néven a p-hidroxi-feniletilalkohol 20-30 mg/L-es koncentrációban mind a fehér-, mind a vörösborok polifenolját képezi, amely a szőlőben nincs, hanem az erjedés során az élesztők szintetizálják tirozinból (RIBÉREAU-GAYON, 1963). A tirozol koncentrációja az érlelés során konstansnak tekinthető.

\subsubsection{Sztilbének}

Az egyszerü fenolok közé tartozik a rezveratrol, amely a sztilbének családjába tartozó fenolos vegyület. Az alapváz kémiai elnevezése $\alpha, \beta$-difenil-etilén.

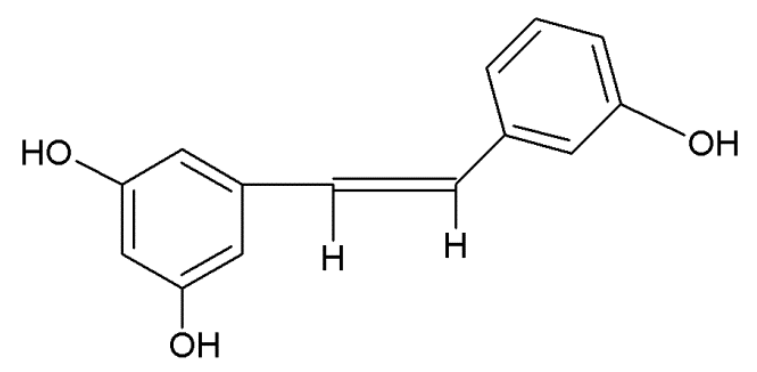

5. ábra: 3,5,4'-trihidroxi-sztilbén

A polifenol típusú vegyületekre jellemző fenolos hidroxilcsoporttal rendelkezik. Két geometriai izomerje van, melyek közül a természetben előforduló és az emberi szervezet számára pozitívan hasznosítható transz-rezveratrol található meg. A cisz forma (izosztilbén) labilis, mivel a fenilcsoportok azonos oldalon való elhelyezkedése által sztreikus gátlás lép fel. Vizsgálatok kimutatták, hogy számos esetben fordul elő glikozidos formában, miszerint a rezveratrol molekulához $\beta$-glikozidos kötéssel egy cukormolekula kapcsolódik (RIBEIRO DE LIMA et al., 1999). Ezt nevezzük piceidnek, vagy polidatinnak, melyből az alkoholos erjedés során a $\beta$ glükozidáz enzimakitivitás által szabadul fel a transz-rezveratrol.

A transz-rezveratrol föként a Vitis vinifera héjában lokalizálódik, érett friss termésben $20 \mu \mathrm{g} / \mathrm{g}$ mennyiségben (JEANDET et al., 1991). A transz-rezveratrol bioszintézise a sztilbénszintáz által történik az epidermiszsejtek membránján és a kloroplasztiszokban (PAN et al., 2009). A folyamat a polifenolvegyületek bioszintézisének sikiminsav-útján zajlik. Az aminocsoport leválásával a fenilalaninból fahéjsav keletkezik, majd a cinnamát 4-hidroxiláz enzim segítségével 
4-kumaráttá alakul. Ezt követően a CoA-val aktiválódik a kumarát, a 4-kumarát-CoA ligáz enzim katalízisével. A folyamatnak fontos enzime a sztilbénszintáz, melynek katalízisével egy darab 4-kumaroil-CoA és három malonil-CoA molekula kondenzálódik, majd egy átmeneti tetraketid molekulán keresztül jön létre a transz-rezveratrol (HALLS C, YU O, 2008).

A rezveratrolmolekulák gyakran fordulnak elő az oxidatív dimerizáció hatására oligomer formában, mint a pallidol és viniferinek (VITRAC et al., 2005), vagy a rezveratrol tetramer formájában, melyet hopeafenolnak nevezünk. Ezt a vegyületet először a Dipterocarpacea családból származó növényekben azonosították, borban pedig Észak-Afrikában izolálták (GUEBAILIA et al., 2006).

A szőlő és a bor rezveratroltartalmát több tényező is befolyásolja. Meghatározó a szőlőfajta, a termőhely, az évjárat, ezen belül a napsütötte órák száma, az UV sugárzás, a hőmérséklet és a csapadék mennyisége. A rezveratrol képződésében nagyon fontos szerepe van a fénynek és a hőmérsékletnek. Az UV-sugárzás indukálja a sztilbénszintáz enzimet, így növelve a rezveratrol mennyiségét a szőlőben. Tehát a szőlő és a bor rezveratroltartalmát minőségi és mennyiségi szempontból a folyamatos, lassú érés befolyásolja kedvezően, a túlmelegedés gátló hatással bír. A szőlőbogyókban elsősorban a héjban akkumulálódik a sztilbén vegyületcsoport, ebből következik, hogy a bor rezveratroltartalma az alkalmazott szőlő-feldolgozási technológia függvénye is. Kardinális jelentőséggel bír a cefreáztatás időtartama és hőmérséklete, az enzimkezelés, a szén-dioxid maceráció, illetve a lékinyerés présnyomásának mértéke. MATTIVI és NICOLINI (1993) mérési eredményei alapján a vörösborokban mért eredmények (2,24 mg/L) magasabbak, mint a fehérborokban. CSOMÓS és SIMON-SARKADI (2002) a héjon erjesztés idejének hatását tanulmányozták az Egri borvidéken.

A rezveratrolnak kettős élettani szerepe van: egyrészt egy növényi védőanyag, fontos szerepet tölt be a szőlő gombás fertőzéseivel szembeni természetes védekező mechanizmusában, ugyanis szintetizálódik a növényben, melynek következményeképpen kiküszöböli a környezeti stressz káros hatásait, valamint védőhatást fejt ki a szőlő patogén fertőzéseivel szemben (YANG, J. et al., 2009).

A 3,5,4'-trihidroxi-sztilbénnek kedvező élettani hatása van a humán szervezetre. Megfelelő koncentrációban fogyasztva szerepet játszik (DANG, LOWIK, 2005) a szív-és érrendszeri megbetegedések, menopauzás tünetek, csontritkulás, diabétesz és több rákos megbetegedés kezelésében és megelőzésében. A rezveratrol antioxidáns tulajdonságú, azaz képes a szabadgyököket megsemmisíteni, ezáltal csökkenti az LDL-koleszterin oxidációját, normalizálva a vér HDL-koleszterinszintjét (BRITO, ALMEIDA, DINIS, 2002). Továbbá szerepet játszik a 
tumorképződés gátlásában: a sérült sejtek programozott sejthalálát indukálja, vagy a kóros sejtosztódást leállítja (FULDA et DEBATIN, 2006). A rezveratrol antioxidáns tulajdonsága miatt végeztek további vizsgálatokat a neurodegeneratív megbetegedések esetén. Vizsgálták az agysejt védelmét az oxidatív stressztől (MIZUTANI et al., 2000), valamint az Alzheimer-kórban szenvedők esetén a $\beta$-amiloid aggregáció gátlását (RIVIERE et al., 2010).

\subsection{Flavonoid fenolok}

A flavonoidok többé-kevésbé intenzív sárga pigmentek, alacsony molekulatömegü és jellegzetes triciklikus struktúrával rendelkező anyagok. Két aromás kört tartalmaznak. A flavonoidokra a $\mathrm{C}_{6}-\mathrm{C}_{3}-\mathrm{C}_{6}$ alap szénváz jellemző, a két benzolgyürü ( $\mathrm{A}$ és $\mathrm{B}$ ) egy oxigénatomot tartalmazó heterociklikus gyürün $(\mathrm{C})$ keresztül kapcsolódik össze (6. ábra). Két benzollánc (A és B) össze van kötve egy középső C lánccal, amely lehet egy $\alpha$-piron, vagy annak dihidro-derivátja.

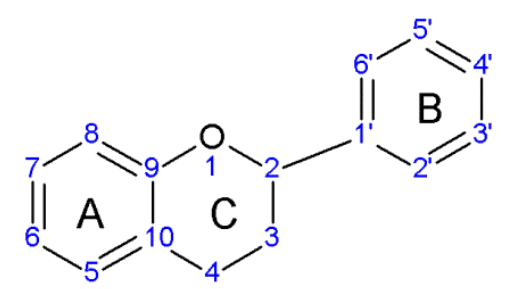

6. ábra: Flavonoidok alapszerkezete

A flavonoidok a növények metabolizmusának másodlagos termékei. Különböző szabályozási folyamatokban vesznek részt - pigmentációban, UV-sugárzás elleni védelemben, mikroorganizmusok és egyéb növényi kártevők elleni védelemben, enzimek működésének szabályozásában, nitrifikációs baktériumok jelző funkcióiban (PRASAD et al., 2009, WANG et al., 2009).

A flavonoidok mennyiségére vezethető vissza a bor fenolos anyagainak változása, illetve az ezzel összefüggő érzékszervi változások - barnulási hajlam, keserü, összehúzó íz (SINGLETON és ESAU, 1969). A flavonoid fenolok csoportjába tartoznak a katechin, leukoantocianin és antocianin monomerek. A monomer molekulák a procianidinek építőkövei, belőlük épülnek fel a különböző polimerizációs fokú származékai. Az alapvegyületek nagy számát a különböző gyürükön előforduló eltérő számú és elhelyezkedésű hidroxilcsoportok eredményezik. A differens variánsok számát a hidroxilcsoportok metilálása és a flavonoidok glikozidos alakban való előfordulása fokozza. Ezekben többnyire cukor, vagy acilezett cukor helyettesíti az aglükon 3., 5. és 7. szénatomján lévő hidroxilcsoportok hidrogénjét. A C-O-cukor, valamint C-O-acilezett 
cukor kötésekkel számottevő mono-, di- és poliglükozid-származék alakulhat ki. A kapcsolódó cukrok lehetnek monozidok, biozidok és triozidok (KÁLLAY, 2010).

A flavonoid fenolok antioxidáns és szabadgyök-fogó tulajdonsággal rendelkeznek, valamint hajlamosak a polimerizációra is. Pozitív élettani tulajdonságai már régóta ismertek, biológiailag kedvező tulajdonságai széles skálán mozognak. Kiemelkedő a hajszálerek rugalmasságát és áteresztőképességét befolyásoló hatás. Emellett még számos kutatás foglalkozik asztma és allergénellenes (YAMAMURA et al., 1998), vírus és baktériumölő, gyulladáscsökkentő (READ, 1995) és antidiabetikus hatásaival (PEREZ et al., 1998). Kiemelkedő szerepet játszanak a kardiovaszkuláris megbetegedések megelőzésében, a francia paradoxon jelensége is a flavonoid fenolok borban lévő jelenlétére vezethető vissza (GOLDFINGER, 2003).

\subsubsection{Katechinek (3-flavanolok)}

A növények metabolizmusának másodlagos anyagcseretermékei. A vegyületek alapváza a 2fenil-kromán váz, melyek vízoldhatóak, hidrolízissel nem bonthatóak, tehát nem észterjellegüek, kondenzált tanninok, vagy flobatanninoknak (7. ábra) nevezzük őket. Kémiai elnevezése a katechuból ered, mely egy csersavlé, vagy a mimóza katechu melegített extraktuma. Kémiai neve: 5,7,3',4-tetrahidroxi-flavanol-3. Összegképlete: $\mathrm{C}_{15} \mathrm{H}_{14} \mathrm{O}_{6}$. Két aszimmetriacentrummal rendelkezik. A szőlőben a (+)-katechin és sztereoizomerje, a (-)-epikatechin fordul elő. A (+)katechinben a hidroxil- és dihidroxilcsoport transzhelyzetü, míg a (-)-epikatechinben cisz helyzetü. A (+)-katechin melegítéskor (-)-epikatechinné izomerálódik. A katechin származékai közül kisebb jelentőségü a (+)-gallokatechin és sztereoizomerje, a (-)-epikatechin, amelyek a galluszsav észterei (KÁLLAY, 2010).

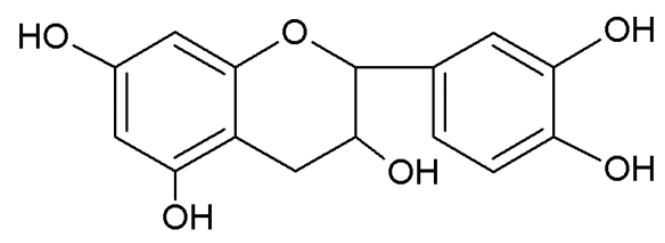

7. ábra: Katechin kémiai szerkezete

A bor P-vitamin aktivitása a 3-flavanolok emelkedésével nő, viszont az öregedés hatására csökken. A katechineknél is kimutatták a humán szervezetre gyakorolt pozitív hatását. Növeli a vérplazmák antioxidáns aktivitását, szerepet játszik a brachiális artéria tágulásában, illetve csökkenti az LDL szintjét, növeli a HDL-szintet (WILLIAMSON et al., 2005). 


\subsubsection{Katechinek szerepe a bor érzékszervi tulajdonságaiban}

A flavonoid fenolokon belül a katechin-monomerek fontos szerepet játszanak a borok organoleptikus tulajdonságainak kialakításában. A 3-flavanolok a borokban elsősorban keserü vegyületek. A monomer katechinek keserübb ízt okoznak, mint polimerizált származékaik, a kondenzált tanninok (ROBICHAUD et NOBLE, 1990). A katechinek és polimerizált származékaik okozzák a keserű és összehúzó ízt a vörösborokban. A katechinek és procianidinek elsősorban keserűek, míg a közepes molekulaszámú kondenzált tanninok egyaránt keserü és húzós ízérzetűek, a nagy molekulaszámú kondenzált tanninok túlnyomórészt húzósak. A nagyméretü tanninpolimerek túl masszívak ahhoz, hogy hatékonyan reakcióba tudjanak lépni az ízreceptorokkal vagy a nyál fehérjéivel. Az érlelés hatására simábbá válnak a vörösborok, ugyanis a katechinek és tanninok polimerizálódnak és kicsapódnak (JACKSON, 2002). Mindkét eljárás során csökken a húzós és keserü ízérzet. A katechin-monomerek fontos szerepet játszanak még a borok testességének kialakításában is. A húzós és keserű ízvilág összefüggésben van a borok édességének és savasságának érzékelésében is, ezzel befolyásolva a borok testességét és harmonikusságát.

\subsubsection{Leukoantocianinok $(3,4$-flavandiolok)}

A flavandiol-3,4 alapváz hidroxilezett származékai, az antocianinok színtelen prekurzorjai (8. ábra).<smiles>[R]c1cc(C2Oc3cc(O)cc(O)c3C(O)C2O)cc([R])c1O</smiles>

8. ábra: Flavandiol-3,4 kémiai alapváza

$\mathrm{Az}$ antocianinok bioszintézise a leukoantocianinokon keresztül megy végbe. A színtelen leukoantocianinok dehidrogénezés révén flavonszármazékokká alakulnak, majd dehidratálás és diszproporcionálódás útján antocianidinek és katechinek jönnek létre. Így tekinthetők az antocianinok prekurzorjainak, azaz proantocianinoknak (KÁLLAY, 2010). Alkoholos sósavval melegítve antocianin-kloriddá alakulnak, mely vörös színü vegyület.

Az önotannin, azaz a borcserzőanyag legnagyobb részét a tannoid alkotja, mely a leukoantocianidin és annak kondenzációs terméke (BATE-SMITH et al., 1973). A leukoantocianinokból képződő leukoantocianidin a redoxfolyamatokban köztes oxidánsként vesz 
részt, tehát antioxidáns tulajdonsággal rendelkezik, ezzel megvédve a borokat a korai öregedéstől.

Érzékszervi szempontból jelentősen befolyásolják a borok minőségét. Összehúzó ízük a polimerizációs fok függvénye. Szerepet játszanak a bor P-vitamin aktivitásában, valamint az óborok színének kialakulásában. Jelentősen befolyásolják a borok testességét, mely egyenes arányban van a minőséggel.

\subsubsection{A katechinek és leukoantocianinok polimerizált származékai}

A monomer flavonoidok kondenzációs reakciók által képzett különböző polimerizációs fokú és molekulasúlyú polimer vegyületei a nem hidrolizálható tanninok, azaz a procianidinek, kondenzált tanninok, tannin-flavonoidok. A kis kondenzációs fokú és molekulatömegü dimer, trimer, tetramer vegyületek vízben jól oldódnak és összehúzó, fanyar íztulajdonságokat hordoznak. A flobafének nagy polmerizációs fokú és molekulatömegü származékok. Alkoholban és lúgos közegben jól oldódnak, viszont vízben rossz oldhatóság jellemző rájuk. Könnyen oxidálódnak a hidroxilcsoportok nagy száma miatt, melynek következtében vörös, valamint sötétbarna színű polimer származékok keletkeznek. A tanninok gátolják az enzimek müködését, ugyanis denaturálják azok fehérjerészét. A must enzimaktivitása folyamatosan és gyorsan csökken, a boroké pedig minimális.

A procianidinek tannintípusú polifenolok, 2-6 egységből álló oligomerek. A borminőség szempontjából kardinális jelentőségű vegyületek. Lényeges szerepet játszanak a stabilitásban és az érzékszervi tulajdonságokban. A szőlő kondenzált tanninjai képesek stabil komplexeket képezni a fehérjékkel, a poliszacharidokkal (RIOU et al., 2002), az alkaloidokkal és a zselatinnal (BATE-SMITH, SWAIN, 1965). A kondenzált tanninok csak a szőlőben fordulnak elő, míg a hidrolizálható tanninok a szőlőben nem, de a borokban kimutathatóak. Részben az érlelés során a tölgyfahordókból, valamint a borkészítés során hozzáadott csersavkészítményekből oldódnak a borba. A kondenzált tanninok az alkoholos erjedés során extrahálódnak. Vörösborokban mennyiségük 1-4 g/L között mutatható ki, de elsősorban az alkalmazott szőlö-feldolgozási és borkészítési technológia függvénye. A fehérborokban mennyiségük 100 és $300 \mathrm{mg} / \mathrm{L}$ között mozog (RIBÉREAU-GAYON et al., 1998).

A technológiai függvényeken kívül még több tényező is befolyásolja mennyiségi és minőségi jelenlétüket: a szőlőfajta (FANG et al., 2003, CHIRA et al., 2009), a termőhely, valamint az adott évjárat klimatikus tulajdonságai (DOWNEY et al., 2003; DE ANDRÉS-DE PRADO et al., 2007). A szőlő fenolos vegyületei közül a procianidinek prekurzorjai, a monomer katechinek határozzák meg döntően a színintenzitást és árnyalatot, valamint felelősek az oxidációs 
folyamatok hatására bekövetkező színmélyülésért, főként a fehérborok esetében. A stabilitáson kívül szerepet játszanak a tisztaságban, valamint az összehúzó, fanyar íz kialakításában. A fenolos vegyületek a szőlő fürtrészeiben különböző mennyiségben és minőségben találhatóak meg. A procianidinek és prekurzorjai a (+)-katechin és (-)-epikatechin elsősorban a héj, mag és kocsányrészekben fordul elő. Hazai vizsgálatok szerint a koncentrációk megoszlása a következő: must $<$ héj < kocsány < mag (KÁLLAY, 1995).

A bor minőségi tulajdonságain kívül jelentős az élettani hatásuk. Korábbi irodalmak megemlítik a baktericidhatásukat, valamint a P-vitamin aktivitásukat. Több kutatás számol be a szív- és érrendszeri betegségek elleni védőhatásáról. A vérben gyorsítják a koleszterin kiürülését, illetve stabilizálják az érfalak rugalmasságát, ezzel megakadályozva az érszükületet és a szívinfarktus kialakulását.

A procianidinek a (+)-katechin és (-)-epikatechin egymással kondenzációs reakciók során képzett oligomer származékai. Tehát nagyon fontos szerepük van a monomer katechineknek, valamint a leukoantocianinoknak is. Polimerizációs fokuk a dimerektől a hexamer állapotig változik. A procianidinek bioszintézise két úton történhet. Az egyik út kiindulási vegyülete a monomer katechin és valamely származéka. Először heterociklusos hidrolitos hasadást szenved, majd ezt követi egy másik molekula katechinnel lejátszódó kondenzációs reakciója, melynek végterméke a procianidin-dimer molekula. A procianidin-dimer kémiai szerkezetét a 9. ábra szemlélteti.<smiles>Oc1ccc(C2Oc3cc(O)cc(O)c3C(c3c(O)cc(O)c4c3OC(c3ccc(O)c(O)c3)C(O)C4)C2O)c(O)c1</smiles>

9. ábra: Procianidin dimer kémiai struktúrája

A másik út kiinduló vegyülete a leukoantocianidin. A leukoantocianidin 3-keto-flavan származékká dehidratálódik, majd az ezt követő diszproporcionálódás után antocianidinek és katechinek keletkeznek. A katechinekből kondenzációs reakció során procianidinek keletkeznek. A dimerek, trimerek átlagos molekulatömege mustok és újborok esetén 500 és 700 Dalton, míg érlelt boroknál 2000 és 3000 Dalton (KÁLLAY, 2010). A kondenzáció egyik flavonoid 
molekula 4-es és a másik C-8 és C-6 atomja között jön létre. A dimerek esetében öt aszimmetriacentrum alakul ki, mely 32 optikailag aktív formát jelent.

\subsubsection{Antocianinok}

Az antocianinok a növényvilágban igen elterjedt vegyületek, amelyek a virágok, gyümölcsök, egyes esetekben a levelek színét adják. Izolálásuk és szerkezetük felismerése elsősorban WillsTätter nevéhez füződik. A kékszőlök és vörösborok színét alapvetően a vízoldható antocianinok határozzák meg. A szőlőfürtön belül a héjban, az epidermisz alatti 3-4 sejtsorban helyezkednek el (AMRANI JOUTEI, GLORIES, 1995). A borba a szőlőből kerülnek át, mennyiségük változó. Az antocianin-koncentráció a Vitis vinifera vörösboraiban 350 és 1500 mg/L értékek között mozog (LEONE et al., 1984).

Mennyiségük és minőségük a szőlőbogyóban jelentősen függ az érettségi állapottól (PÉREZMAGARIÑO et GONZÁLEZ-SAN, 2006). Jelenlétüket több tényező is befolyásolja: a vízstressz (ROBY et al., 2004; KOUNDOURAS et al., 2006), a hőmérséklet (MORI et al., 2005), a felvett tápanyagok és növekedésszabályzók mennyisége (PIRIE, MULLINS, 1976; DELGADO et al., 2004). A szőlőfajta és a termőhely is befolyásolja az antocianinok mennyiségét (VIVAS DE GAULEJAC et al., 2001), de jelentősen mégis a klimatikus faktorok (MORI et al., 2007) határozzák meg. Az áztatás, a pre-fermentáció és az alkoholos erjedés során a színanyagokat tartalmazó „tasakok” felrepednek, és az antocianinok kémiailag változatlanul kerülnek át a mustba, majd a borba. A folyamat végbemenetele függ a bogyóhéj pektin-, cellulóz- és glükántartalmától (ORTEGA-REGULES et al., 2006).

Az antocianinok kémiailag a 2-fenil-benzo-pirillium-glikozid származékai (10. ábra). Az aglükon részt antocianidineknek nevezzük. Az antocianinok a természetben heterozid állapotban vannak jelen, a 3., 5. vagy akár mindkét szénatomra kapcsolódhat cukormolekula (glükóz, galaktóz, ramnóz, arabinóz), mely a vízben való oldhatóságot javítja és megvédi a molekulát a különböző enzimes vagy kémiai behatásoktól. Az antocianinok savas hidrolíziskor, vagy enzimes úton monoszacharidra és aglükonra bomlanak.

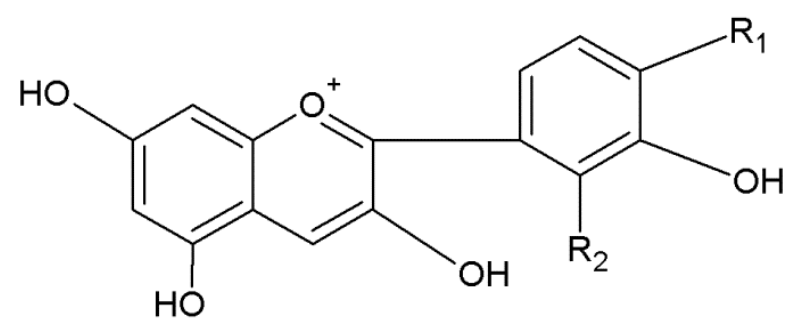

10.ábra: Antocianin kémiai szerkezete 
Az antocianidinek felépítésében a flaviliumváz közös, az eltérést a kapcsolódó fenilcsoportok fenolos hidroxiljainak száma és az észterezettségi fok adja. A természetben hat antocianidin változat található meg.

$\begin{array}{lll}\text { Cianidin } & \mathrm{R}_{1}=\mathrm{OH} & \mathrm{R}_{2}=\mathrm{H} \\ \text { Delfinidin } & \mathrm{R}_{1}=\mathrm{OH} & \mathrm{R}_{2}=\mathrm{OH} \\ \text { Peonidin } & \mathrm{R}_{1}=\mathrm{OCH}_{3} & \mathrm{R}_{2}=\mathrm{H} \\ \text { Petunidin } & \mathrm{R}_{1}=\mathrm{OCH}_{3} & \mathrm{R}_{2}=\mathrm{OH} \\ \text { Malvidin } & \mathrm{R}_{1}=\mathrm{OCH}_{3} & \mathrm{R}_{2}=\mathrm{OCH}_{3} \\ \text { Pelargonidin } & \mathrm{R}_{1}=\mathrm{H} & \mathrm{R}_{2}=\mathrm{H}\end{array}$

A kékszőlőkben és vörösborokban 5 fordul elö, de a legújabb vizsgálatok szerint a pelargonidin és származékai is megtalálhatók a szőlőben és a mustban, melyek az áztatás és az alkoholos erjedés során átalakulnak, vagy kicsapódnak. A Vitis nemzetség fajtáiban antocianinmonoglükozidok, diglükozidok, illetve azok acilezett származékai mutathatóak ki. Az acilezett származékokban általában p-kumársav kapcsolódik a cukorészterhez (FONG et al., 1971). A Vitis vinifera és a Vitis labrusca fajták között különbség figyelhető meg az antocianidinváltozatok mennyiségi és minőségi felépítését tekintve (PALIYATH, NURR, 2006). Az európai kékszőlőfajták színét a monoglükozidok adják, míg a nagyobb mennyiségü diglükozid direkt termő szőlőfajtára utal. A szőlő érése során a zsendülést megelőző 2-3 héttel az antocianintartalom emelkedése figyelhető meg, a szintézis a bogyóhéjban megy végbe, a héj láthatóan elszíneződik (DARNE, 1991). Ezzel egyidőben a szőlőbogyó érése előtt a magban akkumulálódott procianidintartalom csökkenő tendenciát mutat.

Darne (1991) kutatásai alapján az antocianinok szintézise két úton megy végbe a növényi szervtől függően. Összel a vegetáció megszűnése után az antocianinok szintézise a cukrokból indul ki, ugyanis ekkor már a cukormolekulák nem szállítódnak a szőlőbogyó felé. Túlnyomórészt cianidin- és peonidinmolekulák keletkeznek, valamint a flavandiolok mennyiségi növekedése is megfigyelhető. A szőlőbogyóban az antocianinok szintézisének kiinduló vegyületei a zsendülés elött felhalmozódott procianidinek (PIRIE-MULLINS, 1980). Ekkor képződik a malvidin és delfinidin, melyek három szubsztituenst tartalmaznak. Az antocianidinszintézis erőssége szorosan összefügg a procianidin prekurzor szállítással. 
Az antocianin monomerek mennyisége az érlelés során folyamatosan csökken. Ennek okai a különböző kémiai átalakulások. A magasabb hőmérsékleten való tárolás közre játszik a csökkenésben, viszont a $\mathrm{SO}_{2}$ adagolása segít megőrizni a monomerek jelenlétét (DALLAS et al., 1996). Az idősebb vörösborok színanyag-összetételét jelentősen befolyásolják a katechinek és leukoantocianinok is.

\section{Antocianin-koncentráció változása a bor fejlődése során}

A szőlőben az antocianinok monomer állapotban, illetve zsendüléskor acilezett formában is jelen lehetnek. Az erjedés, érés előrehaladtával az antocianin-monomerek koncentrációja csökken, eltérő polimerizált termékek képződnek, melyek kiemelkedően fontos szerepet játszanak az idősebb vörösborok színének kialakításában.

A mustban mérhető antocianin vegyületek mennyisége az áztatás, a prefermentáció és alkoholos erjedés során csökken, annak ellenére, hogy még nem indultak meg a polimerizációs reakciók, mégis a kierjedt újborokban már nem detektálhatóak a kiindulási antocianin koncentrációk. Korábbi vizsgálatok eredményei alapján a mustban lévő antocianinok 40\%-a kicsapódott (KÁLLAY, 1995). Az áztatás és erjedés alatti antocianin-csökkenés oka az egyensúlyi állapot megbomlása, az antocianinok kolloid állapotba mennek át, az élesztők és egyéb zavarosító anyagok felületén adszorbeálódnak, majd kicsapódnak. A kicsapódás mértéke függ az adott szőlőfajtától, borkészítési eljárástól és termőhelytől. A végzett kísérleti eredmények alapján megállapítható, hogy az újborokban mért antocianinok mennyisége az erjedés befejeztével 4060\%-kal csökkent a mustban mért mennyiségekhez képest.

A bor fejlődése, érlelése során az antocianin-monomerek különböző fizikai, kémiai és biokémiai folyamatokon mennek keresztül. A bor kolloidális egyensúlyát az antocianinok befolyásolják. Hideg hatására a színanyagok molekuláris állapotból kolloidális állapotba kerülnek, majd kicsapódnak. A bor tisztulásakor, valamint tisztításakor antocianin-monomer csökkenése figyelhető meg, ugyanis a keletkező csapadékkal, vagy az élesztők felületén adszorbeálódott színagyagokkal kicsapódik. Vörösborok üledékének vizsgálatakor $\mathrm{pH}$ - és $\mathrm{SO}_{2}$-érzékeny antocianin-monomereket mutattak ki.

$\mathrm{Az}$ antocianinok oxidatív úton is lebomolhatnak. A peroxidok, melyek a $\mathrm{Cu}^{2+}$ és $\mathrm{Fe}^{3+}$-ionok katalizálta folyamatokban keletkeznek, a szőlő, a must és a bor antocianinjait oxidatív úton képesek lebontani. Az oxidáció enzimes úton is lejátszódhat, amelyben a polifenoloxidázok vesznek részt. 
A vörösborokban az antocianin-monomerek kondenzálódnak a kénessavval. Reverzíbilis folyamat révén színtelen vegyületek képződnek, mellyel magyarázható a vörösborok kénezés utáni elszíntelenedése. Az elszíntelenedést redukció is okozhatja, valószínűsíthető, hogy a központi heterociklus kettős kötése redukálódik. A $\mathrm{SO}_{2}$ jelenlétében a szabad antocianinmolekulák elszíntelenednek (TIMBERLAKE, BRIDLE, 1976, GLORIES, 1978). A képződött színtelen vegyületek mennyisége függ a monomer antocianinok koncentrációjától. A $\mathrm{SO}_{2}$ színtelenítő hatását nagymértékben befolyásolja a bor polimer\%-a, vagyis minél nagyobb a polimer-antocianinok hányada, annál kevésbé színtelenedik el a bor.

Az antocianin-monomerek érzékenyek a pH változására. Gyengén savas közegben a piros színü forma reverzíbilis egyensúlyban van a színtelen formával. Ez az egyensúlyi helyzet a pH függvénye. Színük savas közegben vörös, növekvő pH mellett színtelenné válnak. Maximális színveszteség 3,2 és 3,5 közötti értékeknél figyelhető meg. pH 4 körüli értéknél a mályvától a kékig terjednek a színvariációk (RIBÉREAU-GAYON, 2006). A polimerizált antocianinszármazékok a pH-ra nem érzékenyek. Az antocianin-koncentrációk csökkenése az érlelés során nem tekinthető színanyagveszteségnek, mivel a monomer-antocianinok egy része polimerizálódik, a polimer színanyagok pedig a pH változásra nem érzékenyek. Érlelt, azaz félegyéves vörösborok esetében a színanyagok 30-40\%-át a polimer vegyületek alkotják. Ez a mennyiség addig tekinthető stabilnak, amíg különböző fizikai, kémiai, mikrobiológiai folyamatok nem érik a bort. Az egyensúlyi állapot megváltozásakor a polimerizációs fok növekedhet, a nagy mólsúlyú vegyületek nem tudnak oldatban maradni, így kicsapódnak. A hosszabb ideig palackban érlelt vörösboroknál a színanyagkiválás ezen módja jelentkezhet.

\section{Antocianinok szerepe a borminőség kialakításában}

Az antocianinok a kékszőlők és vörösborok színanyagai, a legfontosabb alkotórészek egyike, amik nemcsak a színt határozzák meg, hanem az organoleptikus tulajdonságok kialakításában, valamint a bor élettani hatásaiban is szerepet játszanak. A bor színe az érlelés, öregedés során folyamatosan változik, az újborok élénk rubinvörös színe halványul, végül barnás, majd sárgástéglavörössé válik. Ennek több oka is lehet, az egyik az érlelés során a borba kerülő oxigén, azaz az oxidáció folyamata, valamint a festékanyag kolloiddá alakulása és kicsapódása is közrejátszik. Az újborokban az antocianidin-változatok közül a malvidin-koncentráció detektálható a legnagyobb mennyiségben. Viszont az érlelés során az antocianinok metoxitartalma $\left(-\mathrm{OCH}_{3}\right)$ csökkenő tendenciát mutat. A metoxi-index 8-10\%-ról 3-4\%-ra csökken (KÁLLAY, 2010). A metoxigyököt tartalmazó antocianinok: malvidin, peonidin mennyisége a bor érése során kevesebb lesz, míg a metoxigyök nélküli cianidin mennyisége növekszik. A hordós érlelés során 
nemcsak kémiai, hanem fizikai behatások is érik a vörösborokat. A hideg hatására a színanyagok kolloidális állapotba kerülnek és kicsapódnak. A festékanyagoktól megtisztított bor a hideg hatására újrazavarosodhat és kicsapódhat. A kondenzálódás és kicsapódás egy állandó folyamatnak tekinthető. A vörösborok antocianinjai folyamatosan, de lassan hidrolizálnak antocianidinekre és cukorra. Ennek eredményeképpen a redukáló cukortartalom ugyan minimálisan, de ismét emelkedhet.

Az antocianinok kevésbé befolyásolják a bor ízét, viszont szerepet játszanak a stabilitásban és tisztaságban. Az antocianinok tanninokkal való polimerizációja elengedhetetlen a tanninok megtartásában a borokban. Ezzel a folyamattal egy húzós, összetett ízvilág alakulhat ki. Az antocianin-tannin kopolimerizáció folyamata a színanyagok stabilitását, azaz a bor tisztaságát eredményezi.

Az antocianinok a borminőség és organoleptikus tulajdonságok kialakítása mellett kiemelkedő szerepet játszanak a bor pozitív élettani hatásaiban, ugyanis az antocianidinek nagy antioxidáns hatással bírnak. Az antioxidánsoknak kardinális szerepük van az öregedési folyamatok lassításában, emellett gyulladáscsökkentő hatással, anti-tumor tulajdonsággal és koleszterincsökkentő ráhatással rendelkeznek.

\section{Vörösborok színintenzitása, színárnyalata}

A vörösborok minőségi kritériuma az elegáns vörös szín. A borok színének két releváns vonása a színerősség (színintenzitás) és a színtónus (színárnyalat). A színmeghatározásra egy objektív módszert dolgoztak ki, amellyel a bor színe mérőszámmal definiálható. ehhez ismernünk kell a vörösbor 420 nm-en, illetve 520 nm-en mért abszorbanciáját. Ezek az abszorbancia-jellemzők az érés során folyamatosan változnak a különböző biokémiai folyamatok hatására, de jól jellemzik a vörösborok színintenzitását, színárnyalatát. Mind a két paraméter lehetőséget nyújt a szőlő feldolgozásának, a borkészítési metodikáknak és bor korának megállapítására. 420 nm-en a barna színű polifenolokat, míg 520 nm-en a vörös színü antocianinokat mérjük. A két érték összege adja a vörösborok színerősségét (színintenzitás), a hányadosuk pedig a színtónust (SUDRAUD, 1958 ).

$$
\begin{aligned}
& \mathrm{I}=\mathrm{A}_{420+520} \\
& \mathrm{~T}=\mathrm{A}_{420 / 520}
\end{aligned}
$$


A színtónus (T) értékei a következők lehetnek:

$\begin{array}{ll}\mathrm{T}=0,50-0,80 & \text { vörösbor színárnyalata megfelelö } \\ \mathrm{T}=0,80-1,00 & \text { a bor barnatörésre hajlamos } \\ \mathrm{T}>1,00 & \text { a bor barnatörött }\end{array}$

A színintenzitás értékei a következők lehetnek:

$\begin{array}{ll}\mathrm{I} \leq 0,70 & \text { rozé típusú bor } \\ \mathrm{I} \leq 1,00 & \text { siller típusú bor } \\ \mathrm{I}=1,00-2,00 & \text { Kadarka-típusú bor } \\ \mathrm{I}=2,00-3,00 & \text { pecsenye vörösbor } \\ \mathrm{I}=3,00-4,00 & \text { minőségi vörösbor } \\ \mathrm{I}=4,00-5,50 & \text { különleges minőségű vörösbor } \\ \mathrm{I}=8,00-10,00 & \text { gyenge festőbor } \\ \mathrm{I}=10,00-15,00 & \text { közepes festőbor } \\ \mathrm{I}=15,00-20,00 & \text { kiváló festőbor }\end{array}$

(KÁLLAY, 2010)

\subsection{A bor minőségét befolyásoló tényezők}

A bor minőségének kialakulásában az egyik legmeghatározóbb paraméter a szőlő minősége. A szőlő minősége a bor minőségében érvényesül. Fontos viszont megérteni, hogy mit értünk a minőség fogalmán. „Amennyire egyszerü a mennyiség fogalmának meghatározása - mivel az anyagnak mérhető, számokban kifejezhető nagyságáról van szó - annyira bonyolult viszont a minőség fogalmának a meghatározása” (DIÓFÁSI, 1985). A minőség fogalmát több szempontból is meg lehet határozni. A Magyar Élelmiszertörvény szerint az élelmiszerminőség az élelmiszer azon tulajdonságainak összegsége, melyek alkalmassá teszik a rá vonatkozó elöírásokban rögzített és a fogyasztók által elvárt igények kielégítését. Az ISO 8402-1994 szerint a minőség a termék, szolgáltatás, tevékenység, folyamat, szervezet, személy mindazon jellemzőinek összessége, amelyek befolyásolják annak azt a képességét, hogy meghatározott és elvárt igényeket elégítsen ki. A bor minőségét könnyebb érzékelni, mint leírni. AMATI (1991) professzor megfogalmazása szerint: ,a borminőség azon fizikai, kémiai, biológiai, érzékszervi jellemzők összessége, amely mind higiéniai, mind egészségügyi, továbbá a hedonisztikus 
élvezetek szempontjából a fogyasztók számára elfogadható.” A bor minőségének kialakulásában számtalan tényező együttes hatása játszik. A bor minőségét meghatározó tényezők a következők:

szőlőfajta

$>$ termőhely

$>$ fiziografikus tényezők

$>$ klíma

$>$ szőlőtermesztési technológia

$>$ szőlő érettségi állapotai

$>$ borász és borkészítési technológiák.

\section{$\underline{\text { Szőlőfajta }}$}

Az eredményes termelés egyik legfontosabb tényezője a fajta. A speciális fajtatulajdonságok mind a szőlészetben, mind a borászatban hangsúlyosak. Egyes szőlőfajták igényei eltérőek. A szőlőfajták termesztési értékei közül meghatározóak a következők:

$>$ tenyészidő hossza és beérési ideje

$>$ növekedési erély

$>$ termőképesség

$>$ termés minősége

$>$ környezeti igény

$>$ betegségekkel szembeni ellenálló képesség

$>$ fajta viszonyulása a termesztéstechnológiához

$>$ fajták borászati technológiai sajátosságai

$>$ termelésbiztonság (CSEPREGI-ZILAI, 1989).

Borászati szempontból nagyon fontosak a szőlő beltartalmi értékei, a technológiai sajátosságai, és nem utolsó sorban a piacképesség.

Borszőlőfajtáknál kiemelkedő minőségalkotók a következők:

cukortartalom

$>$ savtartalom

$>$ illat-, és zamatanyagok

$>$ cukormentes extrakt (szárazanyag)

$>$ nemes rothadásra való hajlam

> színanyagok (BÉNYEI et al., 1999). 
A szőlőfajta megválasztása egy igen komoly, céltudatos döntés, mivel egy hosszú életü növényről van szó, így a telepítéskor hosszú évtizedekre választjuk ki az adott szőlőfajtát. CSEPREGI (1993) a következő választási tényezőket emeli ki:

$>$ ökológiai feltételek

$>$ üzemi méretek

$>$ termesztéstechnológiai feltételek

$>$ piaci igények

$>$ tudatosan alakított és érvényesített fajtapolitika.

\section{Termőhely}

A szőlő minőségét, ezáltal a bor minőségét nagymértékben meghatározzák a földtani, talajtani és geomorfológiai tényezők. GÁL (2006) az Egri borvidéken hat különböző termőhely borminőségre gyakorolt hatását vizsgálta a Kékfrankos szőlőfajta esetében. Megállapította, hogy nagyon jól kell ismerni a termőhelyet a sikeres gazdálkodás érdekében, ugyanis így lehet optimálisan megtervezni a rügy- és fürtterhelést, így lehet eredményesen megtermelni a kívánt szőlő mennyiségét és minőségét. A talajoknak és kőzeteknek a szőlőfajtára és annak termesztésére gyakorolt hatását nevezzük edafikus tényezőnek. A szőlő a talaj iránt különösebben nem igényes, viszont érzékenyen reagál a talaj tulajdonságaira. Ugyanis a talaj származása, típusa, rétegezettsége, kötöttsége, humusztartalma, mélysége, vízáteresztő és víztartó képessége, mész- és egyéb tápanyagtartalma, tehát a fizikai és kémiai tulajdonságai befolyásolják a szőlőnövényt. A talajok különböző talajképző kőzeteken alakultak ki. A kőzetek geológiai eredetük szerint három fő csoportba oszthatóak:

$>$ Tüzi eredetü kőzetek: gránit, riolit, andezit, bazalt.

$>$ Üledékes kőzetek:

a: fizikai üledékes kőzetek: homok, lösz

b: kémiai üledékek: mészkő, kalcium-karbonát, dolomit

c: szerves üledékek: tőzegek.

$>$ Átalakult kőzetek: nagy nyomás és hőmérséklet hatására az első és második csoportbeli kőzetek bármelyikéből keletkezhetnek.

A talaj fizikai tulajdonságai:

mechanikai összetétel 
> Arany-féle kötöttségi szám

$>$ porozitás

$>$ permeabilitás

$>$ szín, fényvisszaverő képesség

$>$ fajhő.

A talaj kémiai tulajdonságai:

$>\mathrm{pH}$

$>$ karbonáttartalom

$>$ ásványi tápanyagtartalom

$>$ összes vízben oldható só mennyisége, szóda- (nátrium-karbonát)-tartalom

$>$ humusztartalom

> cserélhető kationok (Na, K, Ca, Mg) (BÉNYEI et al., 1999).

Szőlőtermesztésre alkalmas talajtípusok:

váztalajok: vályogos homok, futóhomok, humuszos homok

$>$ kőzethatású talajok: vörös és fekete nyirok

$>$ barna erdőtalaj

$>$ lejtőhordalék

$>$ csernozjom-mezőségi talaj (STEFANOVICS et al., 2010).

A talaj fontos, de nem egyedüli minőségi meghatározója a bornak. A kémiai, fizikai tulajdonságai együttesen fejtik ki hatásukat, melyeket egyéb környezeti tényezők befolyásolnak.

A talajok hatása a bor minőségére:

A talaj és kőzetek hatása valóban érezhető a bor ízében. A talajnak a bor minőségére gyakorolt hatása nem azonos mértékben nyilvánul meg minden fajtánál. A fajta és talaj találkozása egyik fontos feltétele a minőségi borok termelésének (KOZMA, 2001).

> vulkanikus kőzetek borai: nehéz, testes, tüzes, magasabb savtartalmú, kiváló minőségü, lassan fejlődő, lassan öregedő borok

$>$ meszes talajok borai: magasabb savtartalommal és alacsonyabb alkoholtartalommal bírnak, a borok ezeken a talajokon jól tisztulnak, könnyen kezelhetőek

> lösztalajok borai: színben gazdag borok, közepes savtartalmúak, közepes extrakttartalmúak, illatos, zamatos borok. 
homoktalajok borai: lágy, extraktban szegény, könnyen fejlődő, gyorsan öregedő borok, alkoholban gazdagok lehetnek (BÉNYEI et al., 1999).

\section{Fiziografikus tényezők}

A fiziografikus tényezők a klimatikus tényezőkre hatnak, azokat módosíthatják, hozzájárulnak a mikroklíma kialakulásához, mellyel befolyásolják a szőlőtermés mennyiségének és minőségének alakulását (SZ. NAGY, 1986).

> Földrajzi szélesség: a szőlő az északi féltekén a 30-50., a déli féltekén a 20-40- szélességi fokok között termeszthető gazdaságosan. Magyarország a 45,5-48,5. északi földrajzi szélességi fokok között fekszik. Az északi határtól dél felé haladva a cukortartalom és színanyag-összetétel növekszik, míg a savtartalom csökken.

$>$ Tengerszint feletti magasság: erősen befolyásolja a fény-, a hő- és nedvességviszonyokat. Magyarországon 250-300 méter az üzemi szőlőtermesztés felső határa. A legalkalmasabb területek a 150-250 m tengerszint feletti magasságban helyezkednek el.

> Égtáji kitettség (expozíció) és lejtés foka: befolyásolja a hö- és fényviszonyok alakulását. Északon a napsütötte déli fekvések, délen a kevesebb napsütésben részesülő hegyoldalak kedveznek a minőségi szőlőtermesztéshez és borkészítéshez. A legkedvezőbb fekvések Magyarországon: déli, délnyugati, délkeleti és nyugati. A lejtés szöge határozza meg az egységnyi felületre eső fénymennyiséget. Ha a napsugarak beesési szöge a $90^{\circ}$-hoz közelít, akkor több fényenergiát kap az ültetvény.

\section{$\underline{\text { Klíma }}$}

Az éghajlat (klíma) az időjárások összege egy adott helyen, az ottani időjárások rendszere és egyben kerete. A klímától függ, hogy az adott helyen lehet-e szőlőt termeszteni, vagy sem. A lehetőségen belül a szőlőtermesztés fő irányát is a klíma határozza meg.

Makroklíma: nagy kiterjedésű (több ezer $\mathrm{km}^{2}$ ) terület feletti légtér éghajlata. A makroklíma állandó, módosítása az ember rendelkezésére álló energiákkal nem befolyásolható. Jelentősen meghatározza a szőlötermesztést és borkészitést, viszont kevésbé befolyásolja a bor minőségét. Különböző borstílusok kialakítását teszi lehetővé: például azokon a területeken, ahol korai téli fagyok köszöntenek be, lehetőség nyílik jégbor készítésére. A száraz, meleg klímával rendelkező területek pedig sherry típusú borok előállítására alkalmasak. A borász jelenléte nagymértékben 
hozzájárul a minőségi bor készítéséhez, ugyanis megfontoltan és ügyesen kell alkalmaznia a megfelelő technológiai eljárásokat, kihasználva a földrajzi eredetet.

Mikroklíma: kisebb termőhelyi környezetben ható klimatikus tényezők és a szőlőnövény által alakított, speciális éghajlat. Kis távolságon belül is nagyon eltérő éghajlat alakulhat ki egy-egy termőhelyen. A táj domborzati, lejtési, talajviszonyai és más környezeti hatások következményeképpen a talaj felszíne fölötti légtérben a makroklíma tulajdonságai megváltoznak.

A mikroklíma kialakulására a szőlőtermesztésben több tényező is hat:

$>$ szőlöültetvény

$>$ szőlősorok iránya

$>$ tenyészterület nagysága

$>$ lombtömeg magassága

$>$ lombtömeg elhelyezkedése

$>$ sorközök művelése

$>$ makroklíma elemeinek mennyisége és minőségi viszonyai.

Állományklíma: az ültetvényen belül kialakult mikroklíma. A klimatikus tényezők közvetlenül hatnak a szőlő élettani folyamataira, a tőke vegetációjára, a termésmennyiség és minőség alakulására. A mikroklíma a tenyészidő folyamán évszakonként, vegetációs fázisonként változik (KOZMA, 1991).

Fény: A szőlő fénykedvelő növény. A szórt fényt jól hasznosítja, a teljes árnyékot nem kedveli. Kevés fény mellett az ízközök megnyúlnak, a rügyekben nem, vagy szinte alig differenciálódnak a fürtkezdemények, a virágok rosszul termékenyülnek. A szőlő a fotoszintézishez a rendelkezésre álló fiziológiai aktív fény mennyiségének 1-3, max. 5\%-át használja fel. Ez az érték a napfényenergia kihasználási együtthatója. A szőlő fotoszintézisének fő termékei: szénhidrátok, szerves savak és aminosavak. A fotoszintézis mértékétől függően $1 \mathrm{~m}^{2}$ levélfelület naponta 5-12 gramm szénhidrátot képes előállítani. A keletkező szénhidrátok elkezdenek a szőlőnövény különböző részeibe szétáramlani. A virágzás után a teljes érésig a fő áramlási irány a szőlőbogyó. A fénynek szerepe van a bogyók színeződésében is. A napsütötte bogyók vastagabb héjúak, magasabb cukortartalommal és alacsonyabb savtartalommal rendelkeznek. Magyarország borvidékein az évi összes napfénytartam sok év átlagában 1800-2070 óra. A vegetációs idő alatti napsütéses órák száma: 1250-1500. A megfelelő mennyiségü napsütés kedvezően befolyásolja a bor minőségét. 
Csapadék: A csapadékból származik a szőlőnövény egyik legfontosabb alkotórésze, a víz. A víz segíti a talajban található tápanyagok feloldódását, azok felvételét és szállítását. Fontos közege a különböző biokémiai és fiziológiai folyamatoknak. Az 500-600 mm-es évi csapadékmennyiségnél biztonságosan lehet szőlőt termeszteni. A 400 mm-nél kevesebb csapadékkal rendelkező vidékeken már öntözéssel lehet megfelelő termést kapni. A szőlő a vegetációs időszakban eltérő mennyiségben igényli a csapadékot. A legtöbb csapadék a fürt fejlődésekor szükséges, ami nem azt jelenti, hogy ekkor kellenek a nagy esőzések, ugyanis a szőlő mélyre hatoló gyökérzettel rendelkezik, és a talajban összegyült vizet a szükséges időszakban képes felvenni. A nedvességviszonyok függnek a talaj vízmegkötő képességétől és a talajvíz szintjétől. A szőlőtőke környezetének vízviszonyait a levegő és a talajnedvesség mértéke alakítja. Augusztus végén, szeptember elején a nagy esőzések káros hatással lehetnek az ültetvényre, mivel a bogyók felrepednek a túlzott víz mennyiségétől, amelyen megtelepedhet a Botrytis cinerea, azaz a szürkerothadás. Ha az esőzés tartós marad, akkor mennyiségi és minőségi romlás lép fel. Viszont, ha az esőzés után napos, száraz idő következik, akkor akár különleges minőségű borok is készíthetőek. A száraz, aszályos években a szőlő, a must és a bor szárazanyag-tartalma alacsonyabb, mely vékonyabb bort eredményez. Ezzel általában együtt jár az alacsonyabb savtartalom és a lágy karakterü bor (FERENCZI, TUZSON, 1958).

Hömérséklet: A szabadföldi szőlőtermesztés általában 9-21 ${ }^{\circ} \mathrm{C}-\mathrm{os}$ évi középhőmérsékleti izotermák között folytatható biztonságosan (KOZMA, 1991). Magyarország déli 2/3 része a 10$16{ }^{\circ} \mathrm{C}$-os, északi borvidékeink a 9-10 ${ }^{\circ} \mathrm{C}$-os izotermák között terülnek el. A nyári és a kora őszi időszak hőmérsékleti viszonyai együttesen hatnak a minőségi bor kialakulásához. A hőösszeg jó támpontként szolgál a szőlő- és bortermelésben. Ezzel az összeggel jellemezhetőek a borvidékek, az évjáratok, kifejezhető a különböző érésű fajták hőigénye.

Effektív (teljes) hőösszeg: úgy számítjuk ki, hogy a tenyészidőszak középhőmérsékletét megszorozzuk a tenyészidő napjainak számával. A tenyészidőszakot nemzetközileg a tavaszi $+10{ }^{\circ} \mathrm{C}$-os napi középhőmérséklet beállásától az őszi $+10{ }^{\circ} \mathrm{C}$-os középhőmérsékletű napok megszünéséig számíthatjuk.

Aktív (hatásos) hőösszeg: A szőlő vegetációja a $+10{ }^{\circ} \mathrm{C}$-os napi középhőmérséklet beállásával indul, ez a biológiai $0{ }^{\circ} \mathrm{C}$. Az aktív hőösszeget úgy számítjuk ki, hogy a teljes hőösszegből levonjuk a tenyészidő napjai számának tízzel szorzott összegét. Pontosabb agroklimatológiai jellemző, mint az effektív hőösszeg. 
A korai érésű, rövid tenyészidejü fajták minimális aktív hőösszegigénye $900-1000{ }^{\circ} \mathrm{C}$, a késő fajtáké pedig meghaladhatja a $2000{ }^{\circ} \mathrm{C}$-ot (CSEPREGI, 1993). A szőlő tenyészideje Magyarországon sokévi átlagban 185-200 nap között alakul.

A szőlőnövény érzékeny a szélsőséges hőmérsékleti hatásokra, nem kedveli a túl alacsony és a túl meleg hőmérsékletet. A téli tartós hidegek jelentős fagykárt okozhatnak, illetve a tavaszi fagyok is mennyiségi és minőségi kiesést eredményezhetnek. A szőlő gyökerei érzékenyebbek a hidegre, mint a föld feletti, fás részek.

\section{Szőlőtermesztési technológia}

A termesztéstechnológia a termőkorú, nemes ültetvények üzemeltetése, fenntartása, tehát a szőlöültetvényben évről évre végzett müveletek összessége.

Termesztéstechnológia müveletek csoportosítása:

Agrotechnikai műveletek: talajon keresztül ható müvelet.

talajmüvelés

$>$ tápanyagellátás

$>$ öntözés

Fitotechnikai műveletek: növényen keresztül ható müveletek.

$>$ metszés

$>$ metszést kiegészítő műveletek

> zöldmunkák

> szőlőre ható vegyi kezelések

Növényvédelmi kezelések: növényen és a talajon keresztül is hatnak.

Termésbetakarítás.

Ültetvény fenntartási műveletek:

$>$ tőkepótlás

$>$ támrendszer karbantartása

biológiai produktivitás

A borminőségre főként a fitotechnikai müveleteken belül a metszés és a zöldmunkák hatnak. BARÓCSI (2006) több éven keresztül vizsgálta a Bikavér házasításához felhasználható különböző fajták rügy- és fürtterhelését. A tőkénkénti rügy- és fürtszám, valamint a zöldmunkák 
optimális megválasztásával termőegyensúly alakítható ki, amely nagyon fontos a szőlő és borminőség szempontjából.

\section{A szőlő érettségi állapotai}

Az érettség nem abszolút fogalom, nincs könnyen meghatározható fiziológiai értéke. Az érettségben fokozatok vannak, és e fokozatok elérése függ a szőlőfajtától, az időjárási tényezőktől, a szőlőművelés körülményeitől. Az érettség meghatározásának fogalma elsősorban attól függ, hogy mit akarunk elérni. A szőlő érettségének három fokozatát különböztetjük meg: (1) zsendülés, (2) teljes érés, (3) túlérés.

Zsendülés: az érés kezdeti fokozata. A bogyó kezd áttetszővé válni, a fajtára jellemző színt felvenni. Puhul, rugalmas lesz, viaszréteg alakul ki a felületén. A zsendülés időszakában a cukortartalom nő, míg a savtartalom folyamatosan csökken.

Teljes érés: ebben a periódusban a cukortartalom beáramlásának mértéke folyamatosan csökken, ezzel párhuzamosan a savtartalom mennyisége is redukálódik. A bogyók teljes érettsége akkor áll be, mikor már nem áramlik több cukor a bogyókba. A must cukor- és titrálható savtartalma eléri a fajtára jellemző szintet.

Túlérés: a cukorbeáramlás megszűnésével veszi kezdetét. A bogyók vízcsökkenésének és a töppedés következményeképpen a mustnak a cukortartalma, valamint sav- és ásványianyagtartalma koncentrálódik, töményedik. A cukormennyiség növekedése a bogyó vízveszteségének mértékétől függ. A termés mennyisége csökken, viszont a minőségi javulás ezt a hiányt kompenzálja.

Technológiai érettség: az esetek többségében egybeesik a szőlő teljes érettségi állapotával. A külföldi irodalmakban „,sugar ripeness” azaz „cukorérettség”-nek nevezik. Megfelelő cukor-sav aránynak kell lennie. 


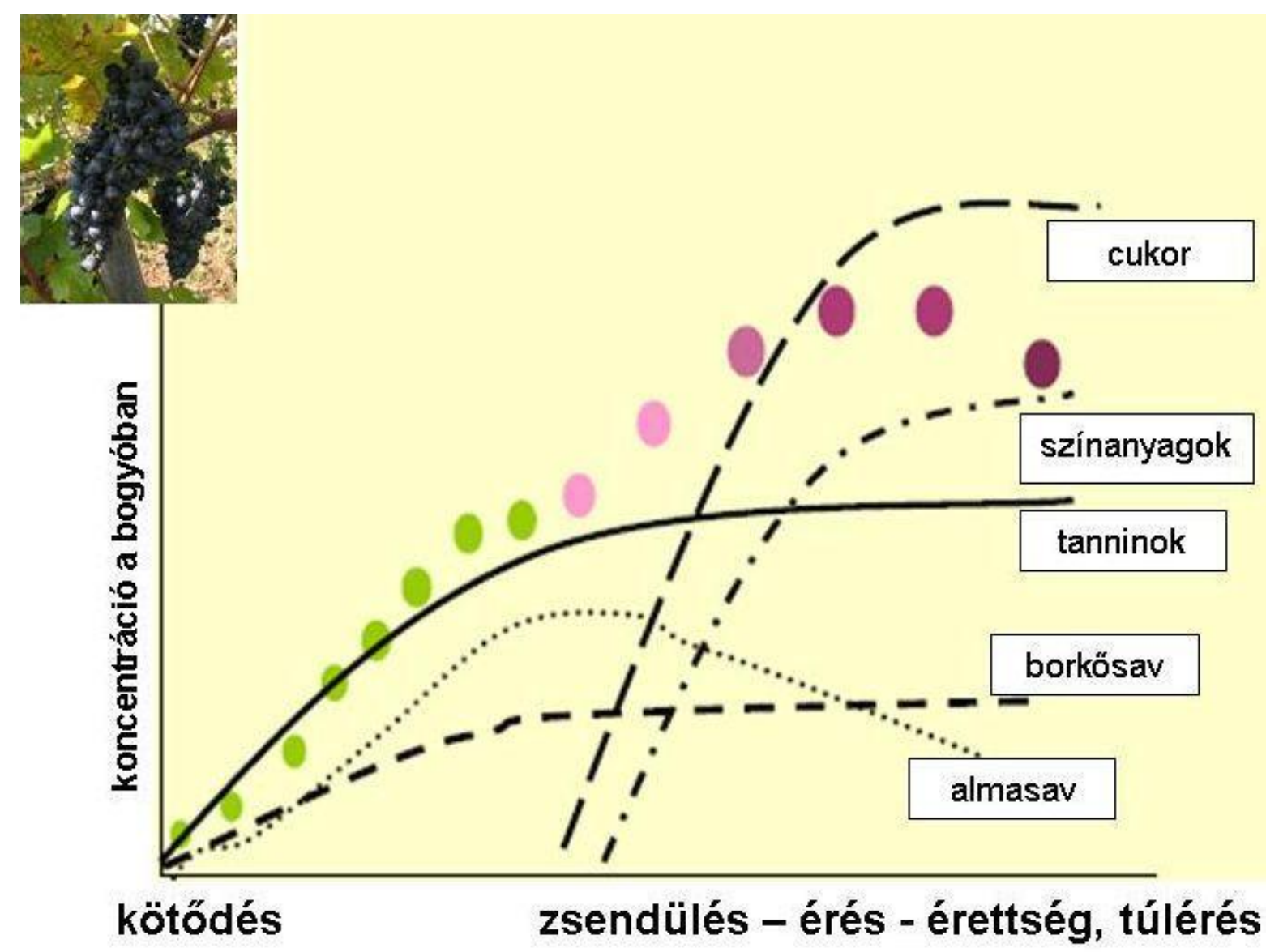

11. ábra: A szőlő érési jellegzetességei (DELOIRE, 2010)

Fenolos érettség: a kékszőlők esetében a fenolos komponensek megfelelő mennyiségü és minőségü jelenléte. Zsendüléstől kezdve a héjban elkezdenek feldúsulni az antocianinok és a tanninok. Ezen vegyületek maximumszintjének elérését nagymértékben befolyásolja az évjárat és a termőhely. Ez a maximum egybeeshet a cukor/sav optimum idejével, azaz a teljes érés időpontjával, de egy rosszabb évjáratban a teljes érettség időszakában messze elmaradhat attól, esetleg elötte mutathat magasabb koncentrációt. A fürt egyes részeinek a tanninjai különbözö molekulaszerkezetüek és más érzékszervi tulajdonságokkal bírnak. Zsendüléskor a mag tanninjai procianidinként vannak jelen, a polimerizációs fok a érés elörehaladtával nő, míg a héj tanninjai kevésbé változtatják polimerizáltsági fokukat. Sokkal komplexebb polimerek poliszacharidokkal vagy antocianinokkal egyesülve jönnek létre (SAUCIER-ROUX, 2000). Egy szőlőfürt akkor fenolosan érett, ha a héj gazdag antocianinokban és kevésbé reakcióképes polimerizált tanninokban. Ez az érettségi állapot finom tanninokat, stabil színt és egy harmonikus minőséget biztosít. A héjszerkezet szőlőfajtánként elérő lehet: a kemény húsú bogyó antocianinkivonatolhatósága jobb (ROLLE et al., 2008). Korreláció figyelhető meg a bogyóhéj roncsolásához kifejtett erő és a héjvastagság között, amely még összefügg a színanyagok kivonatolhatóságával (RÍO-SEGADE et al., 2008). A héj roncsolhatósága és az antocianinok 
extrahálhatósága függ a sejtfal összetételétől és szerkezetétől (ORTEGA-REGULES et al., 2006).

Érettségi index: a must sürüsége és titrálható savtartalma közötti arány alapján a különböző borok készítésére alkalmas technológiai érettséghez ad segítséget (VASSANELLI, 1992). ÉI-hez a must sürüségét négytizedes pontossággal fejezzük ki. A sűrüség egész számát elhagyjuk, és a maradék „tízezred sürüséget” osztjuk a titrálható savtartalom g/l értélével.

Különböző borokhoz javasolható ÉI értékek:

pezsgő alapborok készítéshez 60-70,

könnyü asztali és gyöngyöző borokhoz 70-80,

minőségi borokhoz 80-100 (EPERJESI et al.,1998).

\section{Szakértelem és technológiák}

A borász nagymértékben befolyásolja a bor minőségét. A borkészítő a borászati tudását és művészi készségeit kifejezve alkotja meg a megfelelő minőségű bort, figyelembe véve az adott borvidék fajtaösszetételét, klimatikus, edafikus és fiziografikus adottságait. A borkészítés szubjektív alkotás, ugyanis nincs két borász, aki ugyanolyan körülmények között azonos bort készítene, akár érzékszervi, akár analitikai paraméterek szempontjából. Az adott bor minőségét nagymértékben befolyásolja a borász szakmai felkészültsége, az adott üzem technológiai felszereltsége, valamint a tapasztalat és elgondolásmód egy borstílus kialakításáról. Nagyon fontos, hogy a borászati üzemben a borász folyamatos és szoros kapcsolatban legyen a szőlésszel, hiszen a borász dönti el, milyen stílusú, karakterű bort szeretne elkészíteni, ezért a szőlésznek pontos tájékoztatást kell adnia a szőlő érettségi állapotáról. A 12. ábra a főbb szekvenciákat mutatja a szőlőtől a bor elkészítéséig. 


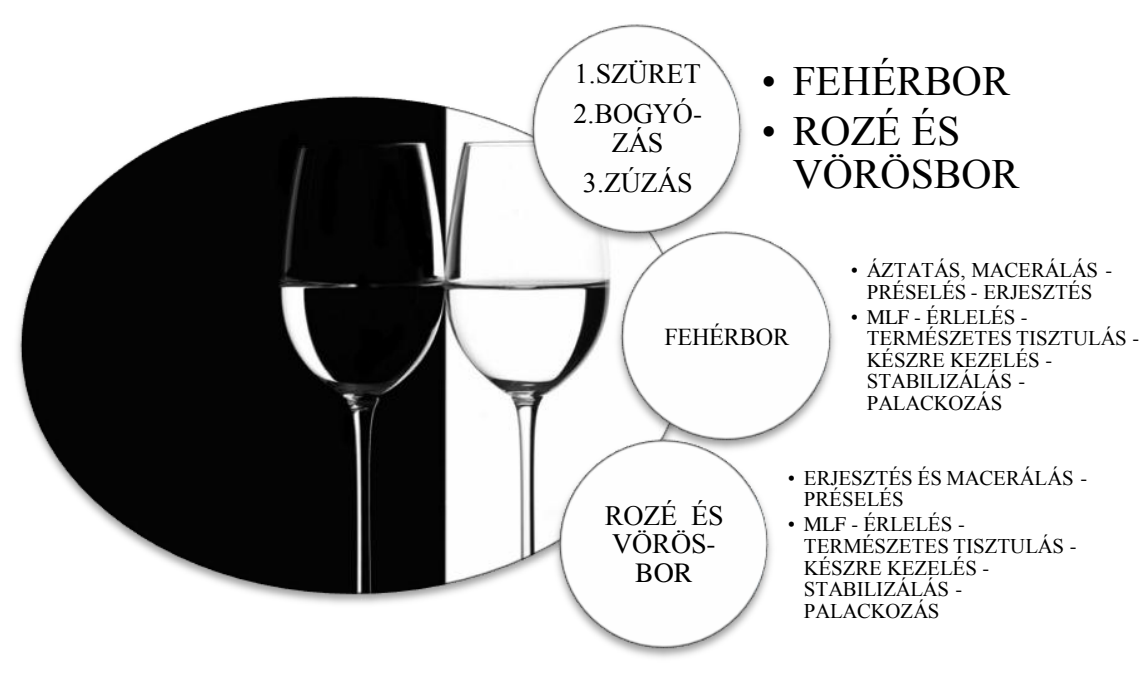

12. ábra: Borkészítés folyamatábrája (JACKSON, 2000)

\subsection{Vörösbor-készítési lehetőségek}

A szőlő megfelelő érettségi állapotának, feldolgozásának és az erjesztéstechnológiának irányzott megválasztásával a kékszőlőből készülhet rozé-, siller-, vörösbor. Hogy milyen bort készítünk, függ a szőlő érettségi állapotától, a választott technológiától, hogy milyen mennyiségben és minőségben kerülnek át a fenolos vegyületek a szőlőbogyóból a borba.

Rozébor: kékszőlőből készül, kevesebb színanyagot és tanninvegyületet tartalmaz. Alacsonyabb alkoholtartalom, a világos szín, a könnyedség jellemzi ez a bortípust.

Sillerbor: kékszőlőből készül, a rozénál több színanyagot tartalmazó, mélyebb színü, teltebb, fanyarabb bor.

Vörösbor: kékszőlőböl készül és a bogyóból kioldható összes fenolos anyag átkerülhet a borba. A vörösbor eleganciáját a színe határozza meg, melyet a gazdag antocianin-tartalom okoz. Az antocianinok a tannin és leukoantocianin vegyületekkel különböző komplexeket alkotnak.

A különböző feldolgozási, érlelési mód szerint készülhet:

$>$ primör vörösbor, újbor, gyümölcsös jellegü,

$>$ gyümölcsös, fiatalos bor,

$>$ nehéz, telt, ászkolt bor,

> barrique hordóban érlelt bor,

$>$ hosszabb ideig palackban érlelt bor (EPERJESI, et al., 1998). 
Az európai fajták bogyóhéjában az antocianinok az epidermisz alatti 3-4 sejtsorban, a héjsejtek vakuólumaiban, illetve a citoplazma fehérjeburkaiban találhatók. A vakuólumokat és a fehérjetasakokat fel kell tárni, hogy a színanyagok, tanninvegyületek, aromaanyagok ki tudjanak oldódni és a folyadékba kerüljenek. Az extrakció feltárására különböző technológiai műveletek léteznek.

\section{Vörösborkészítés héjon erjesztéssel}

Az alkoholos erjedés során keletkező alkohol és hő fehérjedenaturáló és színkioldó hatású. A fehérjetasakok felrepednek, ezáltal a színanyagok és fenolos vegyületek az erjedő mustba áramlanak. Az erjedés elején gyors ütemben történik a színkioldódás, később csökken az extrakció mértéke. Egyhetes héjon erjesztés után csökken a színintenzitás, melynek oka, hogy a színanyagok egy része az élesztősejtek falához, valamint a bogyórészekhez tapad, majd kicsapódik, így színanyagveszteség lép fel. A fenolos vegyületeken belül a fanyar, keserü ízért felelős tanninok is az erjedés elején oldódnak intenzívebben, majd az extrakció lelassul, de folyamatosan nő a koncentrációjuk. A színanyagok és tanninvegyületek komplexei fontos szerepet játszanak a stabilitási folyamatokban. Ugyanis az áztatás során az antocianin és tanninvegyületek egy komplexet képeznek, melynek hatására az antocianinok stabilakká válnak, így a későbbiekben kevésbé léphetnek fel színstabilitási problémák.

A héjon erjesztés módszerét évszázadok óta alkalmazzák szerte a világon. A módszerbeli különbségeket a technológiai paraméterek megválasztásával lehet befolyásolni. A kékszőlőt, melyet héjon erjesztenek, bogyózzák, majd zúzzák. A bogyózás egy fontos eljárás, ugyanis el kell távolítani a kocsányt, mely durva fenolokat tartalmazhat. A cefrét beoltják fajélesztővel, kénezik, illetve pektinbontó enzimeket és speciális kezelő anyagokat is lehet alkalmazni. Az erjedés megindulásával a $\mathrm{CO}_{2}$ hatására a cefre szilárd része (bogyóhéj, húsfoszlányok, magvak) az erjesztőkád felszínére emelkedik, és ott összetömörül. Ezt hívják törkölykalapnak, melyet meg kell bontani és visszameríteni az erjedő folyadékba, ez a héjon erjesztés alappillére. A törkölykalap bemerítésének többféle módja van:

statikus rendszer: szivattyú segítségével teremtik meg a folyadék cirkulációját. A tartály alsó észében lévő folyadékot felszívják, mely a törkölykalap felszínét elárasztja és újra a folyadékba meríti.

$>$ dinamikus rendszer: mechanikus, vagy körforgó rendszer, mely állandó mozgásban tartja a cefrét. Körforgó berendezés a Roto-tartály. A színkioldódás nagyon intenzív, az erjedési ciklus rövid. 
mechanikus és gázbuborékoltatási módszer: a törkölykalap megontását injektorral 2-3 bar nyomású gázbuborékok végzik (CHINAUD-FERRARI, 1992).

Az erjesztés körülményei befolyásolják a szőlőben lévő anyagok kioldódását, ezáltal a készülő bor minőségét. Ezek a tényezők:

$>$ héjon erjesztés hőfoka

$>$ a cefre szilárd és folyékony elegyének érintkezési ideje

törkölykalap visszamerítésének módja.

Az erjesztési hőmérséklet befolyásolja a fenolos anyagok kioldódását, ezáltal a készülő bor stílusát. Alacsonyabb hőmérsékleten gyümölcsös jellegü, fiatalos, könnyed borok készülnek. Magasabb hőmérsékleten jobban kioldódnak a fenolos vegyületek, mely egy testesebb, keményebb karakterü bort eredményez. A héjon erjesztés klasszikus erjesztési hőmérsékleti optimuma: $28-30{ }^{\circ} \mathrm{C}$, az ennél magasabbi hőmérséklet az élesztők tevékenységi aktivitását jelentősen csökkenti, vagy akár el is pusztítja. Az erjesztési idő és az azt követő időszak körülményei jelentősen befolyásolják a színstabilitást (VIVAS, 1993).

A macerációs idő előrehaladtával az antocianin és tanninvegyületek komplexet képeznek, mely elősegíti a vörösborok színstabilitását. Rövid áztatási idő eredményeképpen a vörösbor színtónusa kifakulhat, ugyanis ekkor még az antocianin vegyületek nem stabilak. Az antocianinok stabilitásának eléréshez 1-4 heti héjon áztatás szükséges.

A héjon erjesztés befejeztével a színbort leengedik, a cefrét pedig kipréselik. A szín- és présborokat külön-külön, vagy házasítással kezelik. Az alkoholos erjedést követően a könnyed, friss vörösborokat kénezik, majd lepalackozzák, míg a testes, telt borokat tovább érlelik.

Több fajtával végeztek kísérletet a szénsavatmoszférában történő vörösbor-készítésre. A technológiai tömegminőségű szőlők, valamint a kevésbé aromás szőlőfajták borainak aromadúsítására alkalmas eljárási mód. A friss, gyümölcsös, elsődleges aromák nem maradnak meg tartósan a borokban, így elsősorban primőr borok készítéséhez javasolják (LŐRINCZ, 1997).

Az érlelési folyamatok nagyon változatosak és egyben bonyolult folyamatok. Az érlelés az adott bor jellegének leginkább megfelelő redox viszonyrendszer biztosítását jelenti (PÁSTI, 2002). Az érlelés valójában az oxidációs rendszerek nyomon követését jelenti. A borok érlelésével és fejlődésével kapcsolatos első tudományos munka PASTEUR nevéhez füződik. Az Études sur le vin (1866) tanulmányában Pasteur azt írja, hogy a levegővel való érintkezés ártalmas a borra, 
ugyanis kialakulhatnak káros elváltozások, úgymint a levegőíz, ecetesedés, virágosodás. Szerinte az oxigén nagyon hasznos a bor számára, csak nem mindegy, milyen mértékű az oxidáció. Véleménye szerint az oxigén vegyülése fontos a bor érése, fejlődése szempontjából, viszont az érési folyamatok nem minden része az oxigén hatásának következménye.

\section{Tárolás, érlelés tartályban}

A bor tárolása és érlelése a borkészítés és kezelési technológia jelentős része. A tárolás és érlelés alatt a borban különböző kémiai, fiziko-kémiai és mikrobiológiai változások mennek végbe. A lényeg, hogy ez idő alatt a bort ne érje semmilyen károsodás, hanem az érlelés csak pozitívan befolyásolja a bor minőségét. A borok fejlődését, érését nagymértékben meghatározza a tárolóhely és tárolóedény.

A saválló acél tartályok már évtizedekkel ezelőtt uralkodóvá váltak a nagy bortermelő országokban. Ezeket a tartályokat több borászati technológiai feladatra is lehet alkalmazni. Egyik fő hasznosítása a must erjesztése, melyet más technológiai berendezéssel összekapcsolva (hüthető-füthető rendszer) egy automatizált borászati technológiát lehet létrehozni. Másik hasznosítási területe a bor tárolása. A saválló acél tartályok pórusmenetes szerkezetüek, ezáltal a bornak reduktív környezetet biztosítanak. A bor ezekben a tartályokban a levegőtől teljesen elzárva fejlődik. Az ilyen borok redukált környezetben érik el az érzékszervi tulajdonságaikat, bukéjukat. Ezek a borok már mustkoruktól kezdve a levegőtől elzárva vannak, az így készült borok frissek, üdék, fiatalosak, az elsődleges aromákat őrzik meg. Ezt a borkezelési és érlelési módszert nem lehet minden szőlőfajtánál alkalmazni. A reduktív kezelés a könnyedebb, vékonyabb, üdébb borok készítésére alkalmas, melyek rövidebb idő alatt készülnek el. A saválló acél tartályok előnye a hosszú élettartam, a könnyű tisztítás, ezáltal tökéletesen megfelelnek a higiéniai követelményeknek.

\section{Érlelés fahordóban}

A fahordók nemcsak az érlelést, hanem a borkezelést is szolgálják. A fahordók porózusak, ezáltal a fa szövetein keresztül a bor folyamatosan oxigénhez jut, ami különböző kémiai változásokat idéz elő a borban. A fahordók többnyire tölgyfából készülnek, ugyanis a tölgy szilárd, tartós, tömör szövetü, vízzáró, könnyen megmunkálható és rugalmas. A hordóknak különböző méretei vannak, melyet főként a használati cél határoz meg. Érleléshez főként kisebb ürtartalmú hordókat használnak, mint például Tokaj-hegyalján a gönci és szerednyei hordókat, míg más borvidékeken a barrique hordókat. A barrique érleléshez nagyon fontos a kiváló minőségű alapanyag, az évjárathatás, a termesztési technológia és a precíz borkészítési eljárás. A 
gyenge, vagy közepes minőségű polimerizált és kondenzált polifenolokban szegény vörösbor nem alkalmas barrique érlelése, ugyanis egy idő után a bor szétesik, elvékonyodik, színe kifakul (PÁSTI et al., 1992). A barrique technológia Franciaországból, Burgundiából ered. A szó franciául tölgyfahordót jelent, ami hagyományosan 225 liter ürtartalmú. A hordók a hagyományos ászokhordótól annyiban térnek el, hogy belsejüket kiégetik. A kiégetés erősségétől függően több kategóriát különíthetünk el: enyhe, közepes, erős és nagyon erős pörkölésű. A barrique hordót az első 2-3 évben az érlelésen kívül a barrique íz borba való beoldódására is használják, majd a későbbiekben érlelésre és tárolásra is alkalmazhatják. A bor illata és zamata kiegészül a fa jellegzetes anyagaival és gazdagabbá válik. A fából kioldódó aromáknak a borok komplexebbé, bársonyosabbá tétele mellett az eltarthatóságban, érlelhetőségben is szerepük van, mert kedvezően hatnak a színstabilitást biztosító tannin-antocianin komplex kialakulására és a tanninok polimerizációjára. A barrique-ban érlelt borok hosszútávon megfelelő színstabilitással fognak rendelkezni és sokáig érlelhetőek lesznek a palackban. A vörösborok esetében a tanninok húzóssága és fanyarsága mérséklődik, a bor bársonyosabb érzetü lesz (BALGA, VILLANGÓ, 2012). Ha a tölgyfahordó elveszíti barrique jellegét, akkor chips használatával részben biztosítani tudjuk a barrique-ra jellemző aromákat. A chips a tölgyfadarabkák szárítása és hevítése során jön létre. A hordókhoz hasonlóan ez is többféle pörköléssel érhető el, ezen kívül sokféle méretben kapható. A chipset zsákokba teszik, majd a borban az aromák extrahálódnak. A chipsextrahálódást érdemes összekapcsolni mikrooxigénezéssel, ami a hordós érlelés során ható oxidációs reakciókat hivatott pótolni.

\section{Borok mikrooxigénezése}

A szabályozott oxigénadagolás lehetővé teszi a pórusmentes tárolás alatt lévő borok érettségének biztosítását, fejlődését. Erre szolgál a mikrooxidációs technológia. A technológia kezdeti kidolgozásában az olasz kutatók élen jártak. A kezelendő borba egy automatika által vezérelt berendezés oxigént adagol elöre meghatározott program szerint. A szakirodalomban „microbullage” néven ismert technológia egyre több helyen kerül bevezetésre (FERRARINI, et al., 2001). A mikrooxigénezés egyaránt alkalmazható erjedő tételnél is, melynél az élesztők tevékenységét segíti, illetve újbor állapotban és érleléskor is hasznos lehet (JANKY, KÁLLAY, 2001). A mikrooxigénezés bevett területe a vörösborok érlelése, ahol két fázisban a bor hőmérsékleti függvényében adagolható az oxigén. Kísérletek alapján a mikrooxigénezésen átesett borok kedvezőbb analitikai és érzékszervi paraméterekkel bírnak. 


\section{Házasítás}

A borok élvezeti értéke az összhangtól, a harmóniától függ. Harmonikus egy bor, ha az alkotórészei összhangban vannak egymással, ha kellemes összbenyomást nyújt a bor. Nagyon fontos, hogy a főbb alkotórészek megfelelő mennyiségben és minőségben legyenek jelen a borban. A házasítás az egyik legjobb módja a harmonikus bor kialakításának. A házasítással felerősíthetjük két vagy több szőlőfajta pozitív tulajdonságait, vagy esetleg az összetételbeli hiányosságokat is meg tudjuk szüntetni. Ha a házasítással nem tudjuk elérni a kívánt célt, akkor az egyes alkotórészek javítása, szabályozása válik szükségessé. A házasítás két- vagy többféle bor (vagy must) célszerű összekeverése egyéb beavatkozás nélkül. Házasítani csak akkor érdemes, ha a kevert tétel értéke nagyobb lesz, mint az önálló borok külön-külön (EPERJESI et al., 1998).

Házasítás céljai:

$>$ Nagyobb mennyiségü, egységes bor előállítása. Itt a fajta azonos, csak egy edényben homogenizáljuk.

> Ismert házasítások előállítása: Tokaji aszú, Egri Bikavér, Szekszárdi Bikavér. Ezekre a házasításokra különböző szabályok vonatkoznak.

> Összetételbeli hiányosságok megszüntetése. Például lehet házasítani a savhiányos borokat savas borokkal, gyenge színü borokat mélyebb színűekkel.

A házasítást megelőzi a próbaházasítás. A házasítandó borokat érzékszervileg és kémiailag megvizsgáljuk, majd kis mennyiségben különböző variációkat készítünk. Ezután a próbaházasítás eredményét újravizsgáljuk, mind érzékszervileg, mind analitikailag, valamint mikrobiológiailag is, ezzel ellenőrizve bor stabilitását. Ha az eredmények megfelelőek, erre alkalmas tartályban nagy mennyiségben is homogenizáljuk a bort. Addig keverjük, míg a tartály különböző rétegeiből vett minták között érzékszervileg és kémiailag már nem lehet különbséget tenni.

\section{Egri Bikavér készítésének borászati vonatkozásai}

Az Egri Bikavér az egyik legismertebb vörösbor belföldön és külföldön egyaránt. A borvidéken a termelők és a fogyasztók igényeit egyaránt figyelembe véve a szabályozásokat és rendeleteket folyamatosan kiegészítik. Az uniós elveknek és szabályzatoknak megfelelően termékleírások készültek a borvidéken, mely a korábbi FVM rendeleteken (lásd M1 melléklet) kicsit túlmutatva pontosabb előállítási, forgalomba hozatali és ellenőrzési szabályozást tartalmaznak az Egri borvidék védett eredetü borairól. A termékleírás szerint létezik classicus, superior és grand 
superior Bikavér, melyek különböznek mind érzékszervi, mind analitikai, mind szőlészeti, mind borászati vonatkozásokban is.

Kísérletem során Classicus Egri bikavért készítettem, ezért a következőkben annak foglalom össze főbb jellemzőit.

Egri Bikavér Classicus

Analitikai paraméterek

2. táblázat: Classicus Egri Bikavér analitikai paraméterei (Termékleirás)

\begin{tabular}{|c|c|c|c|c|c|}
\hline & $\begin{array}{c}\text { Minimális } \\
\text { összes } \\
\text { alkoholtartalom } \\
(\mathrm{V} / \mathrm{V} \%)\end{array}$ & $\begin{array}{c}\text { Összes } \\
\text { savtartalom } \\
(\mathrm{g} / \mathrm{L})\end{array}$ & $\begin{array}{c}\text { Tényleges } \\
\text { alkoholtartalom } \\
(\mathrm{V} / \mathrm{V} \%)\end{array}$ & $\begin{array}{c}\text { Maximális } \\
\text { illósav- } \\
\text { tartalom }(\mathrm{g} / \mathrm{L})\end{array}$ & $\begin{array}{c}\text { Maximális } \\
\text { összes } \\
\text { cukortartalom } \\
(\mathrm{g} / \mathrm{L})\end{array}$ \\
\hline $\begin{array}{c}\text { CLASSICUS } \\
\text { EGRI } \\
\text { BIKAVÉR }\end{array}$ & 11,5 & $4,6-6,0$ & $11,5-17,5$ & 1,2 & 5,0 \\
\hline
\end{tabular}

Érzékszervi jellemzők

gránátvörös színmélységtől mély rubin színárnyalatig terjedő Kékfrankos alapú száraz vörösbor házasítás,

$>$ gazdag füszeres íz- és illatvilággal rendelkezik, gyümölcsös jelleget mutat, tanninhangsúly nélkül,

$>$ az érlelési és a friss gyümölcsaromák egyaránt jellemzik a bort

komplex: egyetlen szőlőfajta borának jellege sem uralhatja a házasított bort.

Kötelezően alkalmazandó borászati eljárások

szőlőcefrét legalább 8 napig héjon kell erjeszteni,

préselés csak szakaszos üzemű szőlőpréssel végezhető,

$>$ a bort legalább 6 hónapig fahordóban kell érlelni 
Házasítási szabályok

legalább 3 szőlőfajta bora házasítása kötelező, arányuknak meg kell haladni külön-külön az $5 \%$-ot,

$>$ egy fajta borának aránya nem haladhatja meg az 50\%-ot,

$>$ a Kékfrankos fajtának a használata kötelező, ebből a fajtából kell a legnagyobb arányban házasítani,

$>$ a Turán és Bíborkadarka fajták borának aránya együttesen és külön-külön sem haladhatja meg a $10 \%$-ot,

$>$ a bort édesíteni tilos.

Szőlő minimális cukortartalma (min. potenciális alkoholtartalom)

10,60 V/V\% (17 $\left.{ }^{\circ} \mathrm{MM}\right)$ : Bíborkadarka, Kékoportó, Blauburger, Kadarka, Kékfrankos, Turán, Zweigelt,

12,08 V/V\% (19 $\left.{ }^{\circ} \mathrm{MM}\right)$ : Cabernet franc, Cabernet Sauvignon, Merlot, Pinot noir, Menoire, Syrah.

Körülhatárolt terület: a szőlő termőhelyi kataszter szerint I. és II. osztályú határrészeibe tartozó területek tartoznak ide.

Maximális hozam

$>100 \mathrm{hL} / \mathrm{ha}$ seprös újbor,

> kézi szüret esetén: 13,6 t/ha szőlő

$>$ gépi szüret esetén: 13,1 t/ha szőlő.

Engedélyezett szőlőfajták

Kékfrankos

$>$ Kékoportó

$>$ Kadarka

$>$ Blauburger

$>$ Zweigelt

$>$ Cabernet franc

$>$ Cabernet Sauvignon

Merlot 
$>$ Pinot noir

$>$ Menoire

$>$ Turán

$>$ Bíborkadarka

$>$ Syrah.

Forgalomba hozatal legkorábbi dátuma: a szüretet követő év november 1 . (boraszat.kormany.hu).

\subsection{A fenolos vegyületek szerepe a borkészítés és az érlelés során}

A fenolos vegyületek mennyiségi és minőségi jelenléte a borban függ a szőlőben meghatározható értéktől, valamint a borászati technológiától. A fenolos vegyületek komoly átalakuláson esnek át a szőlő extrakciójától a kész borig. A fenolos vegyületeken kívül a borok esetében nagyon fontosak az érzékszervi paraméterek. A borstabilitás és az élettani hatások egyensúlyba hozhatók az érzékszervi attribútumokkal.

\section{Flavonoid fenolok}

A flavonoid fenolok koncentrációja az erjedés során folyamatosan növekszik, a préselés után is, egészen az almasavbomlás befejeztéig (MAYÉN et al., 1995). A katechin-koncentráció kioldódását vizsgálták a kénessav-adagolás, a képződő alkohol, a macerálási hőmérséklet és az érintkezési idő függvényében. A tényezők hatása külön-külön nem számottevő, viszont az etilalkohol és $\mathrm{SO}_{2}$, valamint a magas extrahálási hőmérséklet elősegíti a fenolos anyagok könnyebb és biztosabb beoldódását a borba (OSZMIANSKI et al., 1986).

A vörösborok erjedése alatt a magból származó katechinek mintegy fele átkerült a borba, míg az oligomer proantocianidinek nem jutottak át (SUN et al., 1999).

Az enzimkészítmények is befolyásolják a fenolos vegyületek minőségét és mennyiségét a borban. Az enzimkészítmények hatására a malvidin-3-monoglükozid csökkenő tendenciát mutat, míg a transz-rezveratrol magasabb koncentrációt eredményezett a borban (WIGHTMAN et al., 1997).

Az etil-alkohol elősegíti a színanyagok és fenolos vegyületek oldódását, viszont gátolhatja a kopigmentációs folyamatokat (CANALS et al., 2005). Az etil-alkohol megkönnyíti még az erjedés elején a rezveratrol extrakcióját a bogyóhéjból (PEZET-CUENAT, 1996). 
A vörösborok festékanyaga az egyik legfontosabb komponensek egyike, mely szerepet játszik az érzékszervi tulajdonságokban és élettani hatásokban is. A bor színe az érés során folyamatosan változik, kevésbé élénk, sárgás-téglavörössé alakul át. A színváltozást több tényező is okozhatja.

Az antocianin molekulák kémiailag nem stabilak, a borban lévő mennyiségük és minőségük az első pár hónapban csökken, majd jelenlétük kezd eltünni az évek során az érlelés hatására, annak ellenére, hogy a vörösbor még mindig vörös színű marad. A csökkenés különböző reakciók hatására megy végbe. Az egyik lehet a kopolimerizáció, melynél az antocianin molekulák egymással képeznek komplexet, illetve az antocianin és tannin molekulák és azok bomlási reakciói. A molekulák közötti reakciók új színanyagok kialakulást eredményezik, mely magyarázatot ad a vörösborok színváltozására és a stabilitásra is (MAZZA et al., 1995).

Az antocianinok stabilitása több tényezőtől függ:

$>$ molekula típusa,

$>\mathrm{pH}$,

$>$ hőmérséklet,

$>\mathrm{O}_{2}$

$>$ fény,

$>$ oldószerek természete.

A borban az antocianinok valódi oldott és kolloid állapotban vannak jelen. Megállapítható, hogy az aglükon rész érzékenyebb a kémiai behatásokra, valamint kedvező élettani hatásokkal rendelkezik. A színanyagok barnulását enzimes, vagy savas hidrolízis előzi meg. A vörösborok antocianinjai lassan, de folyamatosan hidrolizálnak antocianidinre és cukorra, melynek következményeképpen a bor redukáló cukortartalma néhány tized g/L-el emelkedhet.

Gyengén savas kémhatású közegben a vörös színü forma reverzíbilis egyensúlyban van a színtelen alakkal. Az antocianinok színe pH-függő, a pH emelkedésével az antocianinok elszíntelenednek, lúgos közegben színük kék (ADAMS, 1973).

A vörösborok elszíntelenednek kénezés hatására, ugyanis az antocianinok reverzíbilis kondenzációja az $\mathrm{HSO}_{3}{ }^{-}$-anionokkal színtelen vegyületeket eredményez. Ez az elszíntelenedés időszakos. Redukció is okozhat elszíntelenedést.

Különböző fémek hatására, mint például a vas és a réz katalizálta folyamatokban keletkező aktív oxigén, azaz a peroxid behatására az antocianinok oxidációs bomlása felgyorsul (MESCHTER, 1953). Ekkor a bor barnatörötté válhat. A malvidin-3-O-diglükozid peroxiddal való reakciójának 
hatására észter típusú vegyületek jönnek létre (HRAZDINA, 1970). A malvidin-O-glükozid savas közegben több vegyületre bomlik: 2,4,6-trihidroxi-benzaldehidre, sziringisavra és malvidinre (LOPES, 2005).

A vörösborok festékanyagának egy részének kondenzációja és kicsapódása a hideg hatására történik. A megszürt bor egy idő múlva újra hajlamos lesz hideg hatására zavarosodásra és kicsapódásra. Ez egy lassú, de állandó folyamat. Színanyagcsökkenés történhet még adszorbeálódással, mikor az antocianin-molekula megtapad az élesztő felületén, majd leülepedik, és tisztítás során távozik a borból.

\subsection{Borok érzékszervi bírálata}

A bor egy élelmiszeripari termék, de elsősorban egy hedonisztikus alkotás. Az analitikai paramétereken kívül a bor minőségének megállapításához nélkülözhetetlen feladat a szenzorikus vizsgálat. Kizárólag érzékszervi vizsgálattal állapítható meg a bor megjelenése, tisztasága, illata, íze, zamata, utóize, összességében a harmóniája, minősége. A forgalomba hozatali engedély kiadásához az analitikai, stabilitási, mikrobiológiai vizsgálatokon túl hozzátartozik az érzékszervi analízis.

\section{A borbirálat jelentösége, kimenetele}

A borbírálat célja többféle lehet:

> Tájékozódás: a cél a készlet minősítése, a bor állapotának felmérése, a további kezelések eldöntése, vagy az alkalmazott műveletek sikerességének leellenőrzése.

> Laboratóriumi vizsgálatot kiegészítő érzékszervi bírálat: információt ad a bor állapotáról, a bor összetételéről, tisztulási hajlamáról, zavarosodásának mértékéről és sajátosságáról.

> Vevő érzékszervi bírálata: a borok adásvétele megköveteli az érzékszervi minősítést. Fontos, hogy a bor ára és minősége összhangban legyen.

> Borverseny: borok minősítése, rangsorolása történik. Célja, hogy minél szebb, jobban kezelt bor készítésére ösztönözze a termelőt.

A borbírálat szerepe nagyon fontos a gyakorlat, valamint a tudomány területén is. Az érzékszervi bírálatok pontos végrehajtásának alapja a bíráló szakértelme, rátermettsége, a bírálat tárgy feltételeinek megteremtése és a bírálati követelmények betartása.

Borbírálat tárgyi feltételei

Megfelelő helység: a szoba, vagy terem legyen világos, tiszta, szagtalan és megfelelően temperált. 
Optimális szobahőmérséklet: $20-22^{\circ} \mathrm{C}$.

> A bírálóhelyiség jól szellőztethető legyen, kerülendő a konyha, melegítőhelyiség jelenléte, a lényeg, hogy szagmentes környezet legyen a bírálóhelyiség körül.

> Kóstolópohár: nemzetközi szabványban rögzített, talpas pohár, felfelé kúposan szükülő, öblös, kehely alakú, vékony falú, színtelen és sima felületü. A szabványos ízlelőpohár az O.I.V. által elfogadott, melynek ürtartalma $215 \mathrm{~cm}^{3}, 155 \mathrm{~mm}$ magas, amiből $55 \mathrm{~mm}$ a pohár talpára és szárára esik. Legnagyobb öbméret $65 \mathrm{~mm}$ és a felső átmérője $45 \mathrm{~mm}$. Bírálatkor 0,4-0,5 dl bort szoktak bele tölteni.

$>$ A pezsgőt magas, karcsú pohárban kell szervírozni a szénsav mozgása miatt.

$>$ A poharakat tiszta vízzel kell elmosni, majd desztillált vízzel átöblíteni.

$>$ Nagyon fontos a borok optimális hőmérsékleten való szervírozása. A különböző borok illata, zamata csak a meghatározott, megfelelő hőmérsékleten érvényesül.

Borbírálat módszerei

A borok értékelésének több módszere is ismeretes, azonban alapvetően a borbírálat célja határozza meg az értékelés szempontjait. A szakemberek hosszú évek tapasztalatai alapján állították össze a borok objektív bírálati kritériumait. Ezek nélkül sem helyi, sem nemzetközi verseny nem lenne lehetséges. A hivatalos borbírálatoknak, borversenyeknek kettős céljuk van. A termelő visszajelzést kap, hogy másokhoz viszonyítva milyen munkát végzett, a fogyasztó pedig tájékoztatást kap arról, hogy a szakmai zsüri melyik bort milyenek ítélte. Sok bírálatnál differenciamódszereket alkalmaznak, ami azt jelenti, hogy több tulajdonság között kell különbséget tenni.

Hárompoharas módszer

A bírálók három mintát kapnak, melyek közül kettő azonos. Meg kell állapítani, melyik minta az eltérő. Az azonos minták jele A, a különbözőé B. A lehetséges összeállítások: AAB, ABA, BAA. A véletlen valószínűsége egyharmad. A módszert a bírálók kiválasztására, minősítésére, érzékeny értékelő képességük ellenőrzésére, valamint borászati kísérleti minták bírálásához alkalmazzák.

Rangsorolásos módszer

A bírálók a megszámozott mintákat csökkenő, vagy növekvő sorrendbe rakják, és a megfelelő rangszámmal jelzik. Az eredményeket varianciaanalízissel értékelik ki. A módszert kísérleti 
kezelések hatásosságának vizsgálatához alkalmazzák. Hátránya, hogy a minták közötti különbségek mértéke nem érzékelhető.

Pontozásos módszerek

A borbírálatok legtöbb esetben pontozásos rendszerűek. A különböző szintű versenyeken többféle pontozásos módszert alkalmaznak. Az adható maximális pontszámtól függően több pontozásos rendszert különböztetünk meg.

20 pontos módszer

A húszpontos bírálati rendszerben a bor egyes értékmérő tulajdonságaira pozitív pontot adnak. Könnyen, jól alkalmazható kísérleti borok bírálatára. Hátránya, hogy az íz és zamat, valamint az illat, mint értékmérő tulajdonság nincs további paraméterekre bontva, így kevesebb információt tudunk meg a borról.

Vedel-féle módszer

1972-ben vezették be az I. Budapesti Nemzetközi Borvilágversenyen, melyet a Nemzetközi Szőlészeti és Borászati Szervezet (O.I.V.) fogadott el. Ez a módszer fejlődést mutatott a korábbi húszpontos módszerhez képest. A bírálat előtt a borokat minőségi osztályokba sorolták. Minden borkategórián, vagy bortípuson belül azok válnak ki, amelyeknek illó aromaanyaga a legtovább marad a szájban miután lenyeltük, vagy kiköptük. A bornak azt a tulajdonságát, mely az illó természetű anyagokhoz kapcsolódik, zamattartósságnak, azaz perzisztenciának nevezzük. Amikor a bort a szánkba vesszük, két szakaszt különbözetünk meg: az első intenzív, erős szakasz, mely kevesebb ideig tart, illetve a második, gyengébb, de több ideig tartó szakaszt. A perzisztencia megállapításakor az első periódust kell figyelembe venni és másodpercekben mérni eltünésének idejét. Ezt az időt Caudalie-értéknek nevezzük. A borra nézve állandó adat, értéke 115 között változik. A zamattartósság megállapításakor azt az időt kell figyelembe venni, amikor a zamat illó természetủ anyagai hirtelen eltünnek a szájban, nem pedig az utóíz megmaradásának idejét. A Vedel-féle szabályzatban külön csoportosítják a borokat szőlőfajta, (aromás, nem aromás fajta), szín, szénsavtartalom, cukortartalom és speciális készítési technológia szerint. A bírálati módszer alapelve a büntetőpontozás. A különböző érzékszervi tulajdonságok intenzitását és minőségét a bírálati lapon a tulajdonság értékének megfelelően, kereszttel jelölik. Értékeléskor a minél kevesebb hibapontot szerzett minták az eredményesebbek.

Pozitív 100 pontos módszer 
Ezt a módszert 1996-ban vezették be. A Vedel-féle módszer alkalmazásánál a bírálók a borokban a hibákat keresték, nem pedig az értéket, emiatt sokan negatívan bírálták ezt a módszert. Ezért az O.I.V. és a Borászok Nemzetközi Szövetsége (Union Internationale des Oenologues, UNOE) közösen kialakított egy pozitív 100 pontos bírálati rendszert, melyet 2009-ben a tökéletesítés szempontjából egy kicsit átalakítottak. A bírálat során a tisztaságot, a színt, az illat tisztaságát, minőségét, intenzitását, a zamatok tisztaságát, intenzitását, tartósságát, minőségét, illetve a harmóniát értékelik öt szinten. A bírálók száma páratlan, legkevesebb 5, de inkább 7, vagy 9 fö. A bírálati módszer alapelve a pozitív pontozás. Előnye, hogy a borról sokkal aprólékosabb, pontosabb információt kapunk a szakmai zsűri által, ami többet ad a termelőnek és borfogyasztónak egyaránt (KÁLLAY et al., 1998).

\section{Borok érzékszervi tulajdonságai}

A borok érzékszervi minősítése során több paraméter szerint elemezzük a bort.

Megjelenés
tisztaság
$>$ szín
$>$ viszkozitás
> szénsavtartalom

Szaglás

intenzitás

$>$ minőség

> illattisztaság

Ízlelés
zamat
teltség
minőség
gyümölcsösség
füszeresség 
tartósság

$>$ tisztaság

Összbenyomás: A bor illatával, ízével, zamatával, jellegével együttesen beszerzett információk összessége.

\subsubsection{Az ízérzékelés szerepe a borok érzékszervi bírálatában}

A nyál nagyon fontos szerepet tölt be a borok értékelése, bírálata során, mivel ez a „közeg” biztosítja a különböző molekulák szállítását az ízlelőbimbók között. A nyálat a fültőmirigy és a nyelv alatti mirigyek termelik (DAWES-WOOD, 1973). A nyál 99\%-a víz, tartalmaz még fehérjéket, lipideket, enzimeket (amiláz, lipáz), mucint, hormonokat és szervetlen ionokat (WU et al., 1994). Percenként 0,75 ml nyál termelődik (WEATHERELL et al., 1992), ami naponta 1-2 liter nyálat jelent. A nyálelválasztást a vegetatív idegrendszer végzi, melyet különböző fizikai (szaglás, látás), kémiai (savas anyagok) és biológiai ingerek aktiválnak. Vannak különböző ingerek, melyek gátolhatják a nyálfolyást: drogok, különböző érzelmi behatások, vagy keserü anyagok. Mint említettem, a nyál 99\%-a víz, a maradék 1\% külön, illetve együttesen is fontos szerepeket tölt be.

A nyál funkciói

$>$ emésztés

kiválasztás

$>$ antibakteriális hatás

$>$ kenő és nedvesítő szerep, hogy a szájban lévő szöveteket megvédje

$>$ falatképzés

$>$ fogak védelme

$>$ nyeléskönnyítés

$>$ alkalikus $\mathrm{pH}$

> ÍZÉRZÉS (HUMPHREY-WILLIAMSON, 2001).

A nyál nélkülözhetetlen az ízérzékelésben. A ízlelőbimbók rejtetten, mély, keskeny kriptákban helyezkednek el a nyelvünkön. Ha száraz nyelvre egy darab kockacukrot teszünk, nem érezzük az édes ízt, viszont a nyállal való megnedvesítés után felszabadulnak a cukormolekulák, így érezzük az édességet. A nyál e funkcióját a fő összetevője, a víz okozza.

Az ízlelőbimbókban található receptorok csak kis molekulákat és ionokat képesek megkötni, polimereket nem. Az ízek igazi természetének feltárásához a nyálunknak az emésztőenzimeit 
kell használni (MESE-MATSUO, 2007). Az enzimek a speciális kémiai reakciókat felgyorsítják, a nagy molekulaláncokat kisebbekre bontják, így érezzük az adott ízt.

\subsection{2. Ízlelés a nyelven}

A négy alapízt a nyelv különböző területein érezzük (13. ábra). A keserüt a nyelv tövénél, a savanyút hátul oldalt, a sósat előrébb oldalt, míg az édeset elöl.

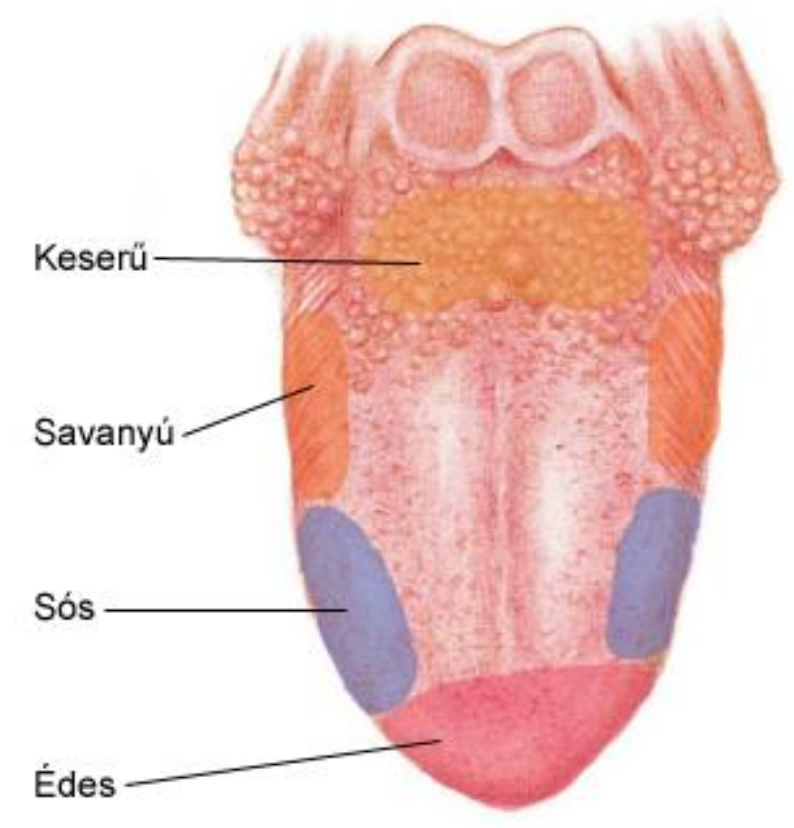

13. ábra: Különböző ízekre érzékeny ízlelőbimbók elhelyezkedése a nyelven

Édes íz

A borban található édes ízérzetet a monoszacharidok alkotják, a bor esetleges cukortartalma glükózból és fruktózból áll. A borok cukortartalma igen változó, függ a must cukorfokától, az erjedés körülményeitől, az élesztő fajtájától és a bor elkészítésétől. A borok többsége száraz, de így is tartalmazhat néhány g/L cukrot. A több cukrot tartalmazó borok tárolása és kezelése több gondot okoz a bekövetkező utóerjedések miatt. 2-3 g/L cukortartalmon felül már érzékszervi bírálatnál érezhető az ízük. Nagyobb mennyiségben módosíthatják a savak érzékszervi hatását. A bor édességének érzetét a cukor fajtája is befolyásolja, nemcsak a mennyisége. A redukáló cukortartalomnál a bor édességi érzete függ a G/F-aránytól. Az édes ízérzetet a második legnagyobb mennyiségü alkotórész, a glicerin is adhatja. Háromértékü alkohol, az alkoholos erjedés során cukorból képződik. Mennyisége függ az élesztő fajtájától és az erjedés körülményeitől. Az édes ízérzeten kívül lágyságot, simaságot, bársonyosságot és testességet kölcsönöz a bornak. 


\section{Savanyú íz}

A szerves savaktól ered a bor savas tulajdonsága. A savak minősége és mennyisége szabályozza a sav-bázis egyensúlyt, ezáltal a bor savas ízét. A bor szerves savai: borkősav, almasav, citromsav, tejsav, borostyánkősav és ecetsav.

A borkősav nagy mennyiségben a bort keménnyé, élessé teszi. Az almasav hideg évjáratokban a fiatal borokat nyerssé, zöld ízüvé teszi. A borostyánkősav sós-keserü-savanyú ízével adja meg az úgynevezett borízt. A bornak a legtöbb ízzel rendelkező sava. A tejsav kellemesebb, lágyabb ízérzetű.

\section{Keserü íz}

A keserüség az alapízek egyike (PEYNAUD et BLOUIN, 1991). A nyelv tövénél érezhető ez az íz, és a bor elfogyasztása után is hosszan megmarad a szájban (ROBICHAUD et NOBLE, 1990). A bor keserü ízét az aminosavak, a peptidek, alkaloidok (SINGLETON et ESAU, 1969), és fenolos vegyületek, úgy, mint a tanninok és fenolsavak okozzák (VERETTE et al., 1988). Néhány esetben a tejsavbaktérium okozta támadások is előidézhetnek keserű ízérzetet a borban (RIBÉREAU-GAYON et al., 1998). 


\section{CÉLKITÜZÉS}

A minőségi borok iránti kereslet növekedése, valamint a harmadik világ versenyképes borainak megjelenése a hazai piacon szinte megköveteli az Egri Bikavér szőlőfajtáinak, illetve a belőlük készült borok mélyreható kémiai és organoleptikus tulajdonságainak feltérképezését, mivel ezen tényezők ismerete lehetővé teszi az Egri Bikavér készítéstechnológiájának optimalizálását. A minőségfejlesztés elérésével a szőlő- és borgazdaságban új lehetőségek nyílhatnak az Egri Bikavér számára, illetve méltán viselheti a zászlós bor szerepét az Egri borvidéken.

A kutatók több szempontból is vizsgálták a vörösborok, valamint az Egri Bikavér minőségfejlesztésének lehetőségeit, mégis szükség van célirányos, szisztemizáló kutatásra a termelés biztonsága, illetve az Egri Bikavér részletes megismerése és tökéletesítése céljából.

Kutatásom során az Egri Bikavért adó szőlőfajtákat vizsgáltam az élettanilag aktív vegyületek szempontjából, hogy miként akkumulálódnak ezen komponensek mind mennyiségileg, mind minőségileg a fürtön belül, mely a későbbiekben egy terméskorlátozási metódust tesz lehetővé.

Munkám másik részét képezte az Egri Bikavért adó szőlőfajtákból készült borok és az azokból alkotott házasítások mélyebb szintü analitikai és szenzorikus vizsgálata.

Kísérletemben tanulmányoztam az érzékszervi attribútumok és a kémiai komponensek közötti kapcsolatviszonyt.

Kutatómunkám alatt a házasítás és az érlelés hatásait elemeztem, mely technológiai elemek mind az analitikai, mind az organoleptikus paramétereket befolyásolják.

Munkám során a következő kérdésekre kerestem a választ:

1. Kimutatható-e különbség a szőlőfürt hossztengelye mentén a fürtrészek között az élettanilag aktív komponensek szempontjából?

2. Van-e kimutatható eltérés az Egri Bikavérhez felhasználható szőlőfajták között a rutin és finomanalízis szempontjából a fürtrészek tekintetében?

3. Az Egri Bikavér készítéséhez engedélyezett szőlőfajták borainak részletes elemzése három évjáratban, illetve a fenti szőlőfajtákból házasított Bikavér vizsgálata, mellyel konkrétabb lehetőségek nyílnak a Bikavér házasításának optimalizálásához mind analitikai, mind organoleptikus szempontból.

4. Van-e hatása az érlelésnek a polifenol vegyületekre vonatkozóan az Egri Bikavérben?

5. Kimutatható-e szignifikánsan az évjárat hatása az Egri Bikavérben? 


\section{ANYAG ÉS MÓDSZER}

\subsection{Kísérlet helye}

\subsubsection{Az Egri borvidék}

A minőségi szőlőtermesztést és borkészítést több tényező is befolyásolja. Többek között kiemelkedő szerepet játszik a földrajzi eredet, maga a borvidék. A klimatikus, földtani, talajtani faktorok, valamint a humán termesztési szokások mind hatással vannak az adott borrégióra.

Az Egri borvidék a Mátra és a Bükk-hegység között, az Északi-középhegység és az Alföld találkozási vonalán fekszik. Az ültetvényeket északon a Bükk-hegység és az Eged-hegy védik a hűvös légáramlatoktól, míg délről egy kontinentális klímájú, száraz meleg széljárás érkezik. Az egri ültetvényeket keletről és nyugatról 2-3000 méter magas dombok határolják. Éghajlata az országos átlagnál hűvösebb, szárazabb. A vegetációs időszak középhőmérséklete $16-18{ }^{\circ} \mathrm{C}$, a nyári középhőmérséklet $20-22{ }^{\circ} \mathrm{C}$, a legtöbb napsütés nyár végén, ősz első felében jellemző. A csapadékeloszlás évközben egyenetlen, az évi átlagcsapadék 550-650 mm között ingadozik. Talaja mészkő, dolomit, riolittufa, illetve agyagpala málladékán alakult ki. Agyagbemosódásos barna erdőtalajok, barnaföldek, és Ramann-féle barna erdőtalajok jellemzők.

A tizenhárom vizsgált szőlö-, valamint borminta, illetve a belőlük készült Egri Bikavér három ültetvényből származik. A feldolgozás, a borok kezelése, a házasítás és az érlelés a KRF Szőlészeti és Borászati Kutatóintézetében történt. Az ültetvények tenyészterülete némely fajta között eltérő, a művelésmód ernyőmüvelés, illetve kordonművelés.

\subsubsection{KRF Szőlészeti és Borászati Kutatóintézete, Eger}

Az Egri Bikavért adó tíz szőlőfajta, majd a 2009-es évtől kezdődően tizenhárom fajta közül a Kutatóintézet területén nyolc szőlőfajtát, majd 2009-től tizenegy fajtát, illetve a belőlük mikrovinifikációs eljárással készült borokat vizsgáltam. Az Intézet területe a termőhelyi kataszter szerint I. osztályú, 3. főclusterbe tartozó, kedvező talajú, optimális fekvésü, kiegyenlített termésmennyiséget adó, szőlötermesztésre kiválóan alkalmas terület. Pontszáma 258. Az ültetvény alapkőzete riolittufa, talaja agyagbemosódásos barna erdőtalaj, mely kötött és nehezen megmunkálható. Arany-féle kötöttségi száma: 44. A sorok tájolása északnyugatdélkeleti. Tengerszint feletti magassága 175 méter. Több fajtából adódóan a tenyészterületek némileg elérőek, illetve az ültetvények kora is eltér némely fajtánál (lásd M2 melléklet).

\subsubsection{Szarkás-dülő, Eger}

A Szarkás-dűlőből a Kékoportó szőlőfajta származik, melynek feldolgozása, erjesztése és kezelése szintén a Szőlészeti és Borászati Kutatóintézetben zajlott. Az ültetvény a termőhelyi 
kataszter szerint I. osztályú, 2. főclusterbe tartozó, barna erdőtalajú. talajú, déli fekvésű, kiváló termésbiztonsággal rendelkező, szőlőtermesztésre rendkívül alkalmas terület. Pontszáma 360 . Az ültetvény alapkőzete riolittufa, talaja barna erdőtalaj, melynek Arany-féle kötöttsége 45. A sorok tájolása észak-déli. Tengerszint feletti magassága 250 méter. Az ültetvény tenyészterülete $3 \mathrm{~m}^{2}$. Müvelésmódja magas ernyő. A telepítés 1996 tavaszán történt (lásd M2. melléklet).

\subsubsection{Kolompos-dülő, Eger}

A termőhelyi kataszter szerint I. osztályú, 2. főclusterbe tartozó, déli fekvésű, optimális termésmennyiséget adó, szőlőtermesztésre kiválóan alkalmas terület. Pontszáma 342. Alapkőzete riolittufa, talaja barna erdőtalaj. Arany-féle kötöttségi száma 42. A sorok tájolása kelet-nyugati. Tengerszint feletti magassága 220 méter. A $3 \mathrm{~m}^{2}$ tenyészterületü ültetvényből a Zweigelt fajta származik, melynek feldolgozása, borkezelése, érlelése szintén a Kutatóintézetben történt. Az ültetvényt 1986-ban telepítették (lásd M2. melléklet).

\subsubsection{A kísérlet ideje}

A kísérleteket három egymást követő évjáratban, 2007 és 2009 között végeztem. A vizsgált minták teljes érés állapotában lettek leszüretelve, melyből az ültetvény három véletlenszerüen kiválasztott tőkéjéről azonos kitettségü fürtöknek a bogyóhéját vizsgáltam. A feldolgozás mikrovinifikációs körülmények között történt. A Bikavér alapborait egyszer fejtett állapotban analizáltam. A technológiai folyamat során egy újborként házasított Bikavért vizsgáltam, majd pedig az érlelés hatását a fenolos vegyületek változása szempontjából, valamint az élettanilag aktív vegyületek mennyiségi és minőségi jelenlétét tanulmányoztam, hogy az alapborokat külön érleltem és azt követően házasítottam.

\subsection{A vizsgált szőlőfajták}

A védett eredetü, klasszikus Egri Bikavért legalább három szőlőfajta borának házasításával lehet elkészíteni. A felhasználható szőlőfajták: Kékfrankos, Kékoportó, Kadarka, Blauburger, Zweigelt, Cabernet franc, Cabernet Sauvignon, Merlot, Pinot noir, Kékmedoc. A 102/2009 V.11. rendelet módosítása alapján bővültek az alkalmazható fajták Turánnal, Bíbor kadarkával és Syrahval. A Turán és Bíbor kadarka aránya együttesen és külön-külön sem haladhatja meg a 10\%-ot. A fajták között a Kékfrankos szőlőfajtának kell a legnagyobb arányt képviselnie. A 2009-es rendelet ezenkívül még magába foglalja, hogy egy fajta borának aránya sem haladhatja meg az 50\%-ot, és legalább három szőlöfajta bora arányának meg kell haladnia külön-külön az 5\%-ot. Tekintettel az Egri Bikavér szabályozásaira, munkám során 2009-ig a védett eredetű klasszikus Bikavért adó tíz szőlőfajtát és a belőlük készült bort vizsgáltam, majd a 2009-es évjáratban a kísérletbe bevontam a még felhasználható három vörösborszőlő-fajtát. 


\section{Kékfrankos}

Származása: ismeretlen. Német M. szerint convar. orientális, subconvar. capsica.

Elterjedtsége: Az összes vörösbort termelő vidékünkön megtalálható, meghatározó jelentőségü fajta. Egyes feltételezések szerint az Olaszországban és Burgundiában is járt ciszterci szerzetesek hozták be Egerbe ezt a szőlőfajtát (BARÓCSI, 2003).

Termesztési értéke: Középérésű fajták csoportjába tartozik, szeptember végén érik. Erős növekedésű, jó termőképességü, értékes fajta. Fekvés és talaj iránt nem igényes, rothadásra kevésbé érzékeny. Kis és nagy tőkeformán egyaránt termeszthető. Bora enyhén illatos, zamatos, testes, fajtajelleges. Az Egri Bikavér vázát képzi. Telepíthető klónjai: G.379; Kt.1-es.

Vizsgált Kékfrankos: SZBKI

Művelésmód: középmagas kordon.

Tenyészterület: $3 \times 1,2$ méter. Telepítés éve: 1993 .

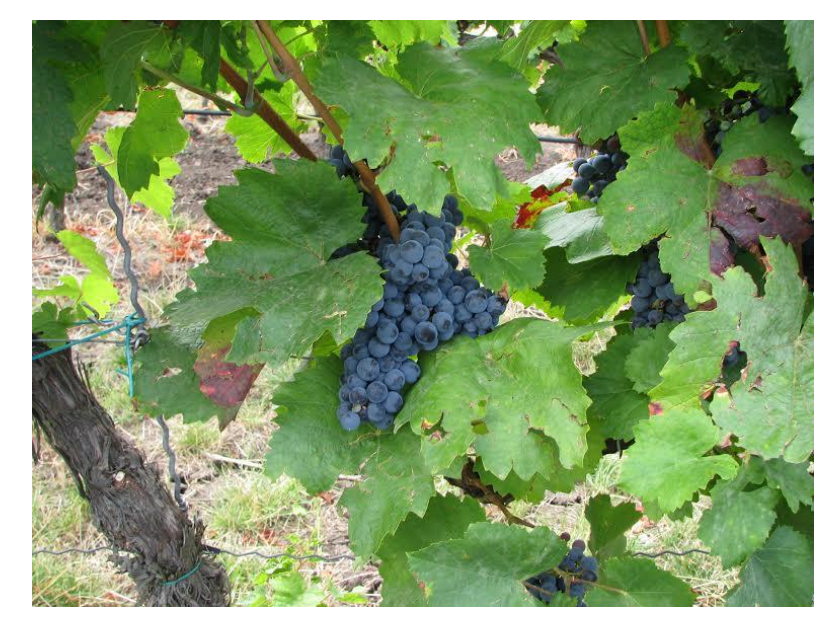

14. ábra: Kékfrankos - SZBKI (Fotó: Villangó Szabolcs)

\section{Cabernet franc}

Származása: francia eredetü, convar. occidentalis, subconvar. gallica, provar microcarpa, subprovar. Carmenet.

Elterjedtsége: régi fajta, már az 1600-as évektől ismerik. Az egész világon elterjedt, világfajta. Magyarországon 1956-ban részesült állami elismerésben. Megtalálható minden vörösborvidékünkön. 
Termesztési értéke: Későn érő fajta. Talaj- és tápanyagigénye mérsékelt. Fagytürő képessége és rothadás-ellenállósága szembetűnő. Bora fajtajelleges, kellemesen testes, bársonyos, kiváló minőségü. Telepíthető klónjai: E.11.

Vizsgált Cabernet franc: SZBKI

Müvelésmód: ernyőmüvelés.

Tenyészterület: $3 \times 1,2$ méter. Telepítés éve: 1974 .

\section{Cabernet Sauvignon}

Származása: francia eredetü, convar. occidentalis, subconvar. gallica. Osztrák szőlészek genetikai vizsgálatokkal úgy vélik, hogy a Cabernet franc és a Sauvignon blanc természetes hibridje.

Elterjedtsége: Franciaországban már régóta termesztik. Világfajta. Minden vörösbort termő vidékünkön megtalálható. Állami elismerésben 1956-ban került sor.

Termesztési értéke: Későn érő fajta, jó cukorgyüjtő. Növekedési erélye közepes. Talaj ás tápanyagigénye közepes, szárazságra nem érzékeny. Kevésbé rothad, közepesen fagytürő, gombás betegségekre való hajlama átlagos. Hosszú metszést igénylő fajta, viszonylag sok zöldmunkája van. Bora bársonyos, kellemesen fanyar kiváló minőségü vörösbor.

Vizsgált Cabernet Sauvignon: SZBKI

Müvelésmód: ernyőmüvelés.

Tenyészterület: $3 \times 1,2$ méter. Telepítés éve: 1974 .

\section{Merlot}

Származása: francia eredetü, convar. occidentalis, subconvar. gallica, provar. microcarpa, subprovar. Carmenet.

Elterjedtsége: a XVIII. század vége óta ismert, Bordeaux környékéről származik. Világfajta. Hazánkba a filoxéravész idején került, 1973 óta tartozik az államilag elismert fajták közé.

Termesztési értéke: késői érésű fajta. Virágzáskori időjárásra érzékeny. A fekvés, a talaj- és tápanyag, valamit víztartalom iránt igényes. Fagyérzékeny. Hosszú metszést igényel, gondos zöldmunkában kell részesíteni. Bora sajátos, bársonyos, gazdag zamatvilágú, kiváló minőségü vörösbor. 
Vizsgált Merlot: SZBKI.

Müvelésmód: ernyőmüvelés.

Tenyészterület: $2 \times 1$ méter. Telepítés éve: 1997 .

\section{Pinot noir}

Származása: francia eredetü, convar. occidentalis, subconvar. gallica. A Pinot fajtacsoport kékbogyójú tagja.

Elterjedtsége: az ókorban már ismert fajta. Öshazája Franciaország. Világfajta. Magyarországon 1993-ban kapott állami elismerést.

Termesztési értéke: közepes érésű fajta. Növekedési erélye közepes. Fekvés és talaj iránt közepesen igényes. Rothadásra közepesen hajlamos. Hosszú metszést igényel, kevés zöldmunkája van. Bora finom zamatú, kissé kemény, ami több éves érlelést igényel.

Vizsgált Pinot noir: SZBKI.

Művelésmód: középmagas kordon művelés.

Tenyészterület: $2 \times 1$ méter. Telepítés éve: 1993 .

\section{Kékoportó/Portugieser}

Származása: bizonytalan. Német Márton szerint convar. orientalis, subconvar. capsica.

Elterjedtsége: Európában elsősorban az északi határrészeken termesztik. Magyarországon 1956ban kapott állami elismerést.

Termesztési értéke: korai érésű fajta, növekedési erélye közepes, bőtermő. Fekvés és talaj iránt közepesen igényes. Fagytürése közepes, rothadásra kifejezetten hajlamos. Hosszúmetszést igényel, zöldmunkaigénye kicsi. Bora finom csersavtartalmú, lágy karakterű, fajtajelleges. Sokszor házasításra használják.

Vizsgált Kékoportó: Szarkás-dűlő.

Müvelésmód: magas kordon.

Tenyészterület: $3 \times 1$ méter. Telepítés éve: 1996 . 


\section{Blauburger}

Származása: a Kékoportó és a Kékfrankos keresztezésével állította elő Müllener. Fajtahibrid.

Elterjedtsége: Magyarországon állami elismerést 1993-ban kapott.

Termesztési értéke: középérésű fajta. Erős növekedési erélyü. Közepes termőképességü. Talaj és fekvés iránt nem igényes. Közepesen fagytürő és szárazságtűrő. Rothadásra nem érzékeny. Hosszú metszést igénylő fajta, kevés zöldmunkát igényel. Bora színanyagban és extraktban gazdag, füszeres, fajtajelleges.

Vizsgált Blauburger: SZBKI.

Müvelésmód: ernyőmüvelés.

Tenyészterület: $2 \times 1$ méter. Telepítés éve: 1993 .

Zweigelt

Származása: a Kékfrankos és a Szent Lőrinc keresztezésével állította elő Zweigelt. Fajtahibrid.

Elterjedtsége: Ausztriában nagy területen termesztik. Magyarországon állami minősítést 1981ben kapott.

Termesztési értéke: középérésü. Erős növekedési erélyü. Bőtermő fajta. Fekvés iránt nem igényes, viszont tápanyagigénye nagy. Rothadási hajlama és szárazságtürése közepes. Bora jellegzetes zamatú, lágyabb karakterü, harmonikus.

Vizsgált Zweigelt: Kolompos-dülő.

Müvelésmód: egyes függöny.

Tenyészterület: $3 \times 1$ méter. Telepítés éve: 1985 .

\section{Menoire}

Származása: convar. orientalis, subconvar. capsica, provar. aminea, subprovar. vulgaris.

Elterjedtsége: Medoc környékéről került hazánkba, melyet Mathiász János hozott be. Magyarországon állami elismerést 1998-ban kapott.

Termesztési értéke: korai érésü fajta. Növekedési erélye és termőképessége közepes. Talaj és tápanyagtartalom iránt igényes. Hosszú metszést és mérsékelt zöldmunkát igényel. Bora füszeres, muskotályos illatú és zamatú. 
Vizsgált Menoire: SZBKI.

Müvelésmód: középmagas kordon.

Tenyészterület: $2,4 \times 1$ méter. Telepítés éve: 2004 .

\section{Kadarka}

Származása: convar. pontica, subconvar. balcanica, provar. mesocarpa, subprovar. dalmatica.

Elterjedtsége: hazánkba a török hódoltság idején került. Leginkább az Alföldön terjedt el.

Termesztési értéke: későn érő fajta. Általában bőtermő, rothadásra nagyon érzékeny. Talaj iránt nem érzékeny, szárazságtűrő, fagyérzékeny. Terhelésre érzékeny, rövid metszést igényel. Bora fajtajelleges, füszeres illatú, színanyagban szegény.

Vizsgált Kadarka: SZBKI.

Müvelésmód: középmagas kordon.

Tenyészterület: $2,4 \times 1$ méter. Telepítés éve: 2004 .

\section{Bibor kadarka}

Származása: a Kadarka és a Muscat Bouschet keresztezésével állította elő Kozma Pál és Tusnádi József. Fajtahibrid.

Elterjedtsége: Állami minősítést 1974-ben kapott.

Termesztési értéke: későn érő fajta, bőtermő. Talaj iránt nem igényes, viszont nagyon fagyérzékeny. Szárazságtürése jó, rothadásra közepesen hajlamos. Kifejezetten zöldmunkaigényes fajta. Festőlevü, azaz nemcsak a bogyó héjában, hanem a húsában is találhatóak színanyagok. Bora színanyagban gazdag, savas.

Vizsgált Bíbor kadarka: SZBKI.

Művelésmód: félszálvesszős ernyőművelés.

Tenyészterület: $2 \times 1$ méter. Telepítés éve: 1999 .

\section{Turán}

Származása: a Bikavér 8 és a Gárdonyi Géza keresztezésével állította elő Csizmazia József és Bereznai László. Fajtahibrid. 
Elterjedtsége: Állami minősítést 1985-ben kapott.

Termesztési értéke: korai érésű fajta. Növekedési erélye közepes. Rothadási hajlama átlagos. Hosszú metszésben kell részesíteni, zöldmunka igénye kevés. Festőlevü, így nemcsak a bogyóhéjban, hanem a húsban is találhatóak színanyagok. Bora csersavban gazdag, finom savtartalmú, füszeres zamatú.

Vizsgált Turán: SZBKI.

Művelésmód: félszálvesszős ernyőművelés.

Tenyészterület: $2 \times 1$ méter. Telepítés éve: 1999 .

Syrah

Származása: Korábban perzsa fajtának vélték, viszont DNS-vizsgálatok alapján francia eredetü.

Elterjedtsége: világszerte termesztik, legnagyobb felületen viszont Franciaországban.

Termesztési értéke: Bőven termő fajta. Hajtásai hosszúak, törékenyek. Rosszul türi a magas aktív mésztartalmú talajokat. Bora ízben és illatban gazdag, tartalmas, kiváló minőségű vörösbor.

Vizsgált Syrah: SZBKI.

Müvelésmód: középmagas kordon.

Tenyészterület: 2,4 × 1 méter. Telepítés éve: 2004 .

A szőlőfajta-leírásokat Bényei: Szőlőfajta-ismeret c. könyve alapján készítettem.

\section{3. Évjáratok jellemzése}

Értekezésem során a kísérleteket három egymást követő évben végeztem: 2007, 2008, és 2009. A vizsgált évjáratok klimatikus szempontból eltérőnek bizonyultak.

A bor minőségét alakító tényezők közül a klimatikus és éghajlati faktorokat az ember nem tudja irányítani. A mért és megfigyelt időjárási és éghajlati adatokból összegzéseket végezhetünk, melyekből konzekvenciákat vonhatunk le az adott vegetációs ciklus évjárathatásairól.

\section{7-es évjárat}

Ebben az évjáratban a nyár meleg volt, a csapadék mennyisége a sokévi átlaghoz képest alacsonyabbnak bizonyult, viszont augusztusban kiemelkedően nagy mennyiségü csapadék hullott, ami a vékony héjú fajtáknál szakadást, repedést okozott. A napsütéses órák száma a 
sokéves átlagnál jóval magasabb értéket mutatott, mely kedvezett a cukorfelhalmozódásnak (3. táblázat + M3 melléklet $)$.

3. táblázat: 2007-es évjárat klimatikus jellemzése

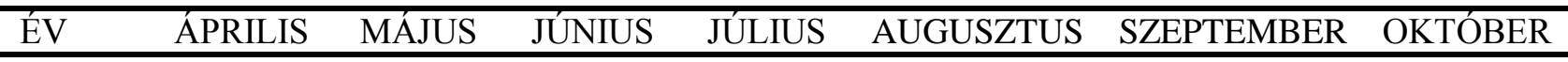

\section{HŐMÉRSÉKLET HAVI ÁTLAGA $\left({ }^{\circ} \mathrm{C}\right)$}

$\begin{array}{cccccccc}2007 & 13 & 17,9 & 21,3 & 22,4 & 22 & 14,8 & 11,1 \\ \text { 48 év átlaga } & 11,5 & 16,8 & 19,9 & 21,7 & 20,8 & 16,4 & 4,8\end{array}$

\section{NAPSÜTÉSES ÓRÁK SZÁMA (h)}

$\begin{array}{cccccccc}2007 & 308,6 & 331,6 & 354,1 & 353,4 & 321,7 & 242,4 & 173,7 \\ 48 \text { év átlaga } & 184 & 247 & 255 & 272 & 255 & 191 & 151\end{array}$

\section{CSAPADÉK (mm)}

\begin{tabular}{cccccccc}
2007 & 9,3 & 69,5 & 67,8 & 53 & 134,7 & 69,1 & 55,9 \\
48 év átlaga & 44,1 & 65,1 & 76,2 & 71,3 & 71,1 & 44,5 & 40 \\
\hline
\end{tabular}

\section{8-as évjárat}

2008-ban a havi átlaghömérséklet a sokévi átlaggal megegyezett, viszont a napsütötte órák száma ebben az évben is magasabb értéket képviselt. Júliusban kiemelkedően sok csapadék esett, viszont a kísérleti területeken ez a mennyiség növényvédelmi problémákat nem okozott. Ez az évjárat átlagosnak nevezhető (4. táblázat + M4 melléklet).

4. táblázat: 2008-as évjárat klimatikus jellemzői

\begin{tabular}{|c|c|c|c|c|c|c|c|}
\hline ÉV & ÁPRILIS & MÁJUS & JÚNIUS & JÚLIUS & AUGUSZTUS & SZEPTEMBER & OKTÓBER \\
\hline \multicolumn{8}{|c|}{ HŐMÉRSÉKLET HAVI ÁTLAGA $\left({ }^{\circ} \mathrm{C}\right)$} \\
\hline 2008 & 11,5 & 16,6 & 20,2 & 20,7 & 20,8 & 15,5 & 12,3 \\
\hline 48 év átlaga & 11,5 & 16,8 & 19,9 & 21,7 & 20,8 & 16,4 & 4,8 \\
\hline \multicolumn{8}{|c|}{ NAPSÜTÉSES ÓRÁK SZÁMA (h) } \\
\hline 2008 & 236 & 330,5 & 327,2 & 335,3 & 343,1 & 219,4 & 183,9 \\
\hline 48 év átlaga & 184 & 247 & 255 & 272 & 255 & 191 & 151 \\
\hline \multicolumn{8}{|c|}{ CSAPADÉK (mm) } \\
\hline 2008 & 61,8 & 81,8 & 68,4 & 140,7 & 36,3 & 61,3 & 60,1 \\
\hline 48 év átlaga & 44,1 & 65,1 & 76,2 & 71,3 & 71,1 & 44,5 & 40 \\
\hline
\end{tabular}




\section{9-es évjárat}

2009-ben a napsütéses órák száma és a havi átlaghőmérséklet magasabb volt a sokévi átlaghoz képest. A csapadék heves záporok formájában rövid idő alatt hullott. Az évet nagyon száraz tavasz jellemezte, amit a júniusi csapadékos időszakon túl meleg, száraz nyár követett. Az érési ciklusban is nagyon kedvező klimatikus feltételek voltak, melyek felettébb optimálisan hatottak a szőlő minőségbeli alakulására. Magas cukortartalmú, színanyagokban gazdag, kiváló minőségű borok születtek ebben az évjáratban (5. táblázat + M5 melléklet).

5. táblázat: 2009-es évjárat klimatikus jellemzői

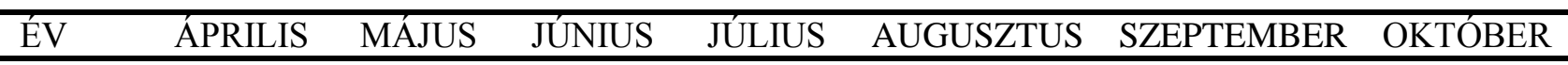

\section{HÖMÉRSÉKLET HAVI ÁTLAGA $\left({ }^{\circ} \mathrm{C}\right)$}

$\begin{array}{cccccccc}2009 & 14,7 & 16,8 & 18,2 & 22,7 & 21,6 & 18,6 & 10,9 \\ 48 \text { év átlaga } & 11,5 & 16,8 & 19,9 & 21,7 & 20,8 & 16,4 & 4,8\end{array}$

\section{NAPSÜTÉSES ÓRÁK SZÁMA (h)}

$\begin{array}{cccccccc}2009 & 321,1 & 342,2 & 320,3 & 367,5 & 318,4 & 274,8 & 139,2 \\ 48 \text { év átlaga } & 184 & 247 & 255 & 272 & 255 & 191 & 151\end{array}$

\section{CSAPADÉK (mm)}

\begin{tabular}{cccccccc}
2009 & 5 & 35,6 & 138,6 & 56,4 & 39,2 & 32,9 & 49,9 \\
48 év átlaga & 44,1 & 65,1 & 76,2 & 71,3 & 71,1 & 44,5 & 40 \\
\hline
\end{tabular}

\subsection{Minta-előkészítés}

Értekezésem során három évjáratban a teljes érettségben leszüretelt szőlőből vett minták héját, bogyóhúsát és a mikrovinifikációs eljárással készített újborokat és óborokat vizsgáltam kémiai és organoleptikus szempontból.

\subsubsection{Szőlőhéjextraktum előkészítése}

A vizsgálandó fürtöket teljes érettség állapotában a kísérleti ültetvény három, véletlenszerüen kiválasztott tőkéjéről gyüjtöttem be, a fürtök azonos kitettségüek voltak. A fürtöket a minta további feldolgozásáig azonnal lefagyasztottam $-20{ }^{\circ} \mathrm{C}-$ ra.

Méréskor a fagyott fürtök hosszát lemértem, és a hossztengely mentén három egyenlő részre osztottam. Ezek után tíz darab fagyott szőlöbogyónak a héját óvatosan, manuálisan leválasztottam a bogyóhúsról. A tíz darab bogyóhéjat analitikai mérlegen lemértem. A bogyók cukortartalmának a méréséhez a felengedett bogyóhúst kipréseltem laboratóriumi körülmények között. 
A szőlőhéjhoz oldatot készítettem, melyeket csiszolt dugós Erlenmeyer lombikokba helyeztem, és 48 órán keresztül fénytől elzárt helyen tároltam. Az oldat 1\% cc. HCl-t tartalmazó 60:40 arányú metil-alkohol:desztillált víz elegye. 48 óra után az extraktumot redős szürőn keresztül elválasztottam, majd a térfogatot normál lombikokban 25 mL-re állítottam be desztillált vízzel. Az így elkészített bogyóhéjkivonatok készen álltak a spektrofotometriás és kromatográfiás vizsgálatokra.

A mérési eredmények az összetevők 1 L bogyóhéjextraktumra vonatkoztatott koncentrációját jelentették. A kapott értékeket $1 \mathrm{~kg}$ bogyóhéjmennyiségre számítottam át az extrahált héjmennyiség pontos tömegének ismeretében. A bogyóhéjban mért összetevők koncentrációértékei [mg/kg héj] dimenzióban kerülnek közlésre.

\subsubsection{Mikrovinifikáció}

Minden évjáratban $(2007,2008,2009)$ teljes érés állapotában történt a szüret. Egyik évjáratban sem voltak növényvédelmi problémák, így a kísérlet zökkenőmentesen ment vége. A szüret kézzel történt, ládákba szedve. A 2007-es és a 2008-as évjáratokban tíz szőlőfajtával, míg 2009től a Bikavér-szabályzat módosítása miatt már tizenhárom fajtával dolgoztam. Minden évjáratban minden egyes fajtánál a szüretet próbaszüret előzte meg. 2007-ben a szüret szeptember elején kezdődött és október közepén fejeződött be. Az évjáratot magas cukortartalom és vörösborokhoz képest magas savtartalom jellemezte. A 2008-as szüret ugyancsak szeptemberben kezdődött és október közepén fejeződött be. 2009-es szüret augusztus végén kezdődött és már október elején befejeződött. Rendkívül magas cukortartalom és szép, finom savak jellemezték ezt az évet.

A feldolgozás mikrovinifikációs körülmények között zajlott. A gépi bogyózás és zúzás után kisebb tartályokba került a cefre. Irányított erjesztés történt minden egyes tételnél. Élesztős beoltás (dózis: $30 \mathrm{~g} / \mathrm{hL}$ ) és komplex tápanyag (dózis: $20 \mathrm{~g} / \mathrm{L}$ ) hozzáadása után történt meg a cefrekénezés $(50 \%$-os törzsoldat, $1 \mathrm{~mL} / \mathrm{L})$. Az erjesztési tér hömérséklete: $24{ }^{\circ} \mathrm{C}$ volt, így az alacsony hőmérséklet okozta erjedési problémák nem álltak fenn, az erjedés zavartalanul ment végbe. A törkölykalap lébe való visszajuttatása a csömöszölés technikájával történt napi három alkalommal. A macerációs idő átlagosan húsz nap volt (fajtánként eltérő). Az alkoholos erjedés befejeztével, mikor a cefre szárazra kierjedt, kosaras prés segítségével kipréseltük a mintákat.

Préselés után a borok üvegballonokba kerültek. Az újborokból vizsgálat céljából (analitikai és organoleptikus analízis) le lettek palackozva a minták, valamint újbor állapotban megtörtént az első házasítás. A házasítási arányok minden évben ugyanazok voltak. Az arányok a következők: 
Kékfrankos: $35 \%$

Cabernet franc: $10 \%$

Cabernet Sauvignon: $10 \%$

Merlot:10\%

Blauburger: $10 \%$

Zweigelt: $10 \%$

Menoire: 5\%

Pinot noir: $5 \%$

Kadarka: 5\%

Kékoportó: 5\%

A 2009-es évjáratból kettő házasítási verzió született. Az egyik ugyanaz, mint 2007 és 2008-ban, másik verzióban még hozzákerült a Syrah, Bíbor kadarka és Turán szőlőfajta is.

Minden egyes tételnek a szabad kénessav-tartalmát $40 \mathrm{mg} / \mathrm{L}-\mathrm{re}$ állítottam be. A borok 25-30 L-es üvegballonokban érlelődtek tovább több mint egy évig. Ekkor az érlelt borokból is történt egy házasítás, illetve vizsgálatok is. A vizsgálatokhoz szükséges mintákat az üvegballonokból vettem ki. A komponensek borokban mért koncentrációeredményeit 1 L borra vonatkoztatva közlöm.

\subsection{Vizsgálati módszerek}

Szőlőhéj extraktumban mért paraméterek:

összes polifenol

$>$ antocianin

$>$ leukoantocianin

$>$ katechin

> sztilbének: transz-piceid; transz-rezveratrol; cisz-piceid; cisz-rezveratrol

Mustban mért mutatószámok:

$>$ redukáló cukortartalom

$>$ titrálható savtartalom

$>\mathrm{pH}$ 
Borban mért komponensek:

> redukáló cukortartalom

$>$ titrálható savtartalom

$>$ szárazanyag-tartalom

$>\mathrm{pH}$

$>$ alkoholtartalom

> összespolifenol-tartalom

$>$ antocianin-tartalom

$>$ leukoantocianin-tartalom

$>$ katechintartalom

$>$ összes rezveratroltartalom

$>$ színintenzitás

$>$ színtónus

Az adott évjáratok borai két alkalommal kerültek analízisre: újbor, majd óbor állapotban. Fontos volt az érlelés és házasítás hatásainak a kémiai és érzékszervi mutatószámokra gyakorolt impulzusait vizsgálni.

A bor, mint élvezeti cikk esetében kiemelkedő jelentősége van az analitikai paramétereken kívül az érzékszervi vizsgálatok elvégzésének is. Mindhárom évjáratban az alapborokat és a házasított mintát újbor és óbor állapotában is érzékszervileg bírálták a szakemberek.

\subsubsection{Rutinanalitikai vizsgálatok}

Az alapanalitikai vizsgálatokat a KRF Szőlészeti és Borászati Kutatóintézet boranalitikai laboratóriumában végeztem az országos magyar szabványoknak és a borászati gyakorlatnak megfelelően.

Próbaszüretkor a cukortartalom megállapításához refraktométert használtam, melyből magyar mustfokot $\left[{ }^{\circ} \mathrm{MM}\right]$ fejeztem ki. A mustok redukáló cukortartalmát Rebelein-módszerrel, az MSZ 9479-1980 szabvány szerint, a titrálható savtartalmat az MSZ 9472-1986 szerint, az extrakttartalmat piknométeres módszerrel, az MSZ 9463-1985 szerint, a pH-értéket az MSZ 14849-1979 szerint potenciometriásan, míg az alkoholtartalmat az MSZ 9458-1972 szerint határoztam meg. 


\subsubsection{Spektrofotometriás vizsgálatok}

A spektrofotometriás vizsgálatokat $\mathrm{BCE}$ Borászati Tanszékének Kutatólaboratóriumában végeztem MOM Spektromom 195 típusú készülékkel.

$\mathrm{Az}$ összespolifenol-tartalmat Folin-Ciocalteu fenolreagenssel mértem, galluszsav egyenértékben (mg/L) kifejezve SLINKARD et SINGLETON (1977) módszerével.

$>\mathrm{Az}$ antocianin-tartalom RIBÉREAU-GAYON és STONESTREET (1966) módszerével lett meghatározva.

> A leukoantocianint FLANZY és munkatársai (1969) eljárása szerint vizsgáltam.

A katechintartalom méréséhez REBELEIN (1965) vanillines színreakción alapuló módszerét használtam.

$>$ A színintezitás $\left(\mathrm{A}_{420+520}\right)$ és színtónus $\left(\mathrm{A}_{420 / 520}\right)$ SUDRAUD (1958) módszerével került meghatározásra.

\subsubsection{Kromatográfiás vizsgálatok}

A sztilbén vegyületcsoport minőségi és mennyiségi meghatározását nagyteljesítményü folyadékkromatográfiás eljárással (HPLC) végeztem a BCE Borászati Tanszék kutatólaboratóriumában. A rezveratrolmeghatározás metodikáját KÁLLAY és TÖRÖK (1997) dolgozta ki.

Minták előkészítése

A minták szüréshez $0,45 \mu \mathrm{m}$ pórusátmérőjü Sartorius laboratóriumi membránszürőt alkalmaztam.

> A bogyóhéj- és a borminták egyaránt szürés után injektálhatóak voltak a HPLC készülékbe.

A rezveratrolmeghatározás izokratikus módon történt HP Series 1050 típusú készülékkel. Minden mintában (bogyóhéjkivonat, bor) mind a négy sztilbénvegyületet analizáltuk: transzpiceid, transz-rezveratrol, cisz-piceid, cisz-rezveratrol.

A mérések kalibrációjához a kereskedelmi forgalomban kapható standardeket használtam (Sigma Aldrich, US). A szőlőhéjban mért rezveratrolkoncentráció eredményei mg/kg héj, míg a borokban mért értékek mg/L dimenzióban kerülnek közlésre. 
A rezveratrolmérés meghatározásának körülményei és a kromatográf beállításai:

Oszlop: LiChrospher ${ }^{\circledR} 100 \mathrm{CN}(125 \times 4 \mathrm{~mm} ; 5 \mu \mathrm{m})$; (Merck, Germany).

Detektor: HP Series 1050.

Folyadékáram: $2 \mathrm{~mL} / \mathrm{min}$.

Hullámhossz: $306 \mathrm{~nm}$.

Hőmérséklet: $30^{\circ} \mathrm{C}$.

Eluens: 5:5:90 = acetonitril:metil-alkohol:desztillált víz.

LQD: $0,1 \mathrm{mg} / \mathrm{L}$.

LOQ: 0,05 mg/L.

\subsubsection{Organoleptikus analízis}

A bor egy hedonisztikus alkotás, így az analitikai vizsgálatokon kívül mindenképp organoleptikus bírálat alá kell vetni a bort. Kizárólag érzékszervi vizsgálatokkal állapítható meg a színe, tisztasága, illata, aromája, íze, karaktere, intenzitása, hosszúsága és a végén a harmóniája, összbenyomása.

\section{A kísérleti borok érzékszervi vizsgálatának körülményei:}

A bírálat módszere: 100 pontos módszer.

A bírálati módszer kiértékelése: profilanalízis segítségével történt.

A minták újbor, majd rá egy évre óbor állapotában kerültek bírálatra. A borok érzékszervi analízisét egy öt főből álló, kellő szakértelemmel rendelkező bizottság hajtotta végre vak bírálattal. A bírálóhelyiség optimális volt: tiszta, világos, szagtalan, megfelelően temperált. A kóstolópohár a nemzetközi szabványban (O.I.V.) leírtaknak megfelelt. A bírálók az alapborokat, valamint a házasított tételt, azaz a Bikavért is érzékszervileg analizálták.

A borokban a következő paramétereket vették figyelembe a bírák:

SZÍN: a bor színtónusa; barna és vörös árnyalatok.

ILLAT: intenzitás, minőség, gyümölcsösség, füszeresség, fajtajelleg, idegen illat.

ÍZ, ZAMAT: savasság, húzósság, keserüség, gyümölcsösség, minőség, idegen íz, harmónia. 


\subsubsection{Eredmények statisztikai kiértékelése}

Szőlőhéjextraktum-vizsgálatok esetében évjáratonként három szőlőfajtával dolgoztam, három ismétlésben. A borok esetében az élettanilag aktív vegyületek három egymást követő évjáratban, 2007-ben, 2008-ban és 2009-ben került meghatározásra. Az ismétlések számát az évjáratok jelentik.

Az eredmények kiértékeléséhez varianciaanalízist alkalmaztam, mely egyező szórású, normál eloszlású csoport átlagának összesítésére alkalmas statisztikai módszer. Mérési eredményeimet kéttényezős varianciaanalízissel (MANOVA) értékeltem ki.

A kiértékelés során normalitásvizsgálatot végeztem, de némely kiértékelésnél a minőségi paraméterek esetében a normalitás sérült néhány kiugró érték miatt. Ezért logaritmustranszformációt hajtottam végre, melynek hatására a K-S teszttel igazolni tudtam a transzformált adatokból származó reziduumokra az értékeket $(\mathrm{p}>0,05)$. A szóráshomogenitás teljesülése esetén a Tukey-tesztet alkalmaztam, ellenkező esetben a Post hoc tesztnél a GamesHowell módszert használtam.

Nullhipotézis szerint:

ha p<0,05, akkor a nullhipotézist elvetjük, van különbség, az átlagok nem egyenlők.

ha p>0,05, akkor a nullhipotézist megtartjuk, nincs különbség, az átlagok egyeznek, azaz nincs szignifikancia.

A statisztikai kiértékelést az IBM SPSS 20 statisztikai szoftvercsomaggal végeztem. A statisztikai elemzéseket a BCE Matematika és Informatika Tanszék közremüködésével készítettem (TABACHNICK, 2013). 


\section{EREDMÉNYEK ÉS ÉRTÉKELÉSÜK}

\subsection{Szőlőhéjextraktumok}

A bogyóhéj-vizsgálatokat mind a három évjáratban (2007, 2008, 2009) statisztikailag az ANOVA és a MANOVA módszerével érékeltem ki. Kutatási munkám során a fürtön belüli élettanilag aktív vegyületek mennyiségi és minőségi akkumulálódására kerestem a választ, azaz a fürtön belül hol lokalizálódnak nagyobb mennyiségben a fenolos vegyületek. A következő grafikonok (15., 16., 17., 18., 19., 20.) szemléltetik a szőlőhéjkivonatok élettanilag aktív vegyületeinek eredményeit. Fajtánként a fürtrészek értékei átlageredményt jelentenek. Az eredményeket táblázat formájában az M6., M7., M8. mellékletek tartalmazzák.

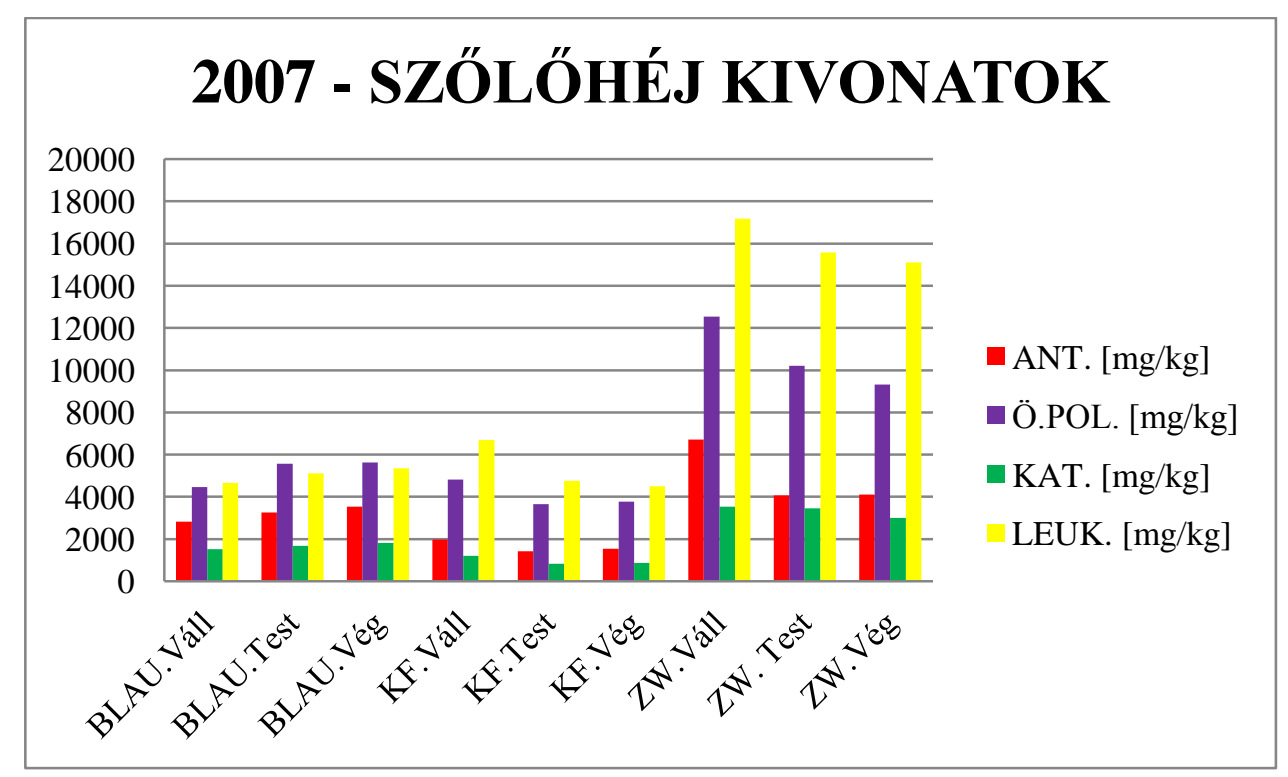

15. ábra: Szőlőhéjextraktumok vizsgálatainak eredményei a 2007-es évjáratban 


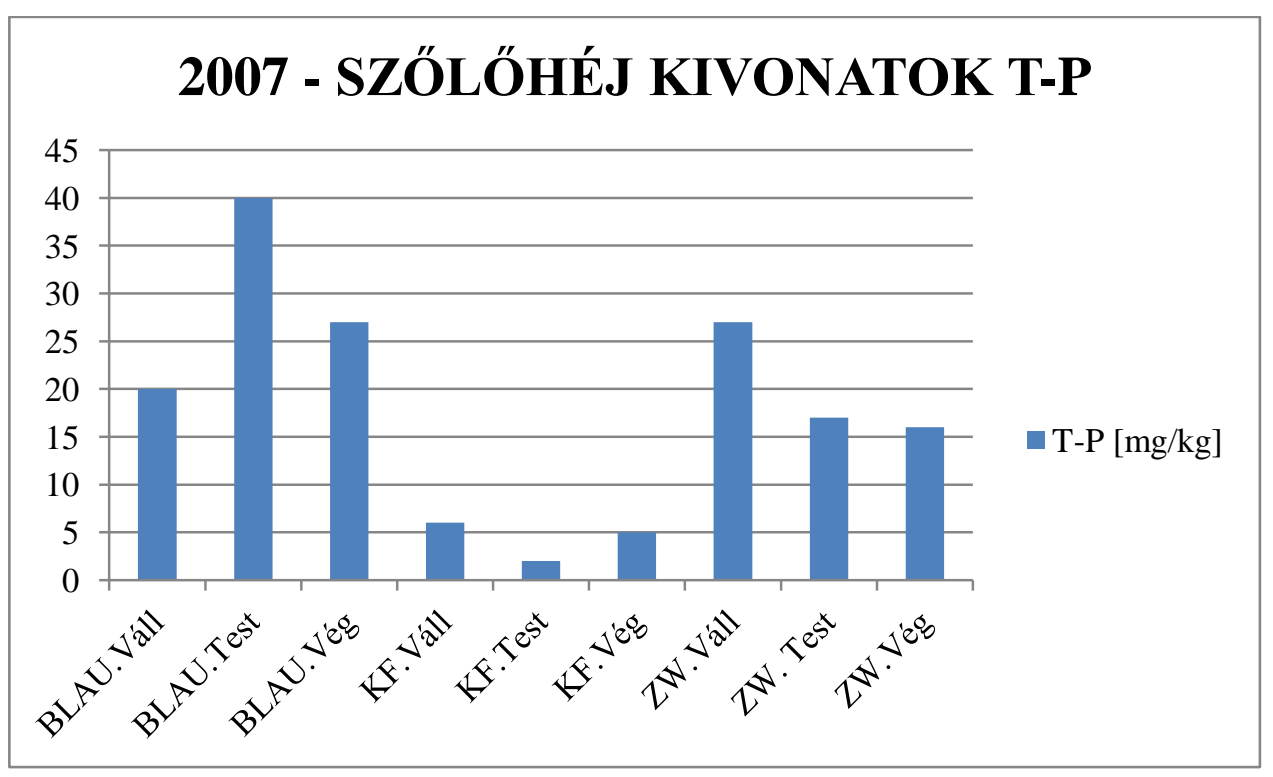

16. ábra: Szőlőhéjextraktumok transz-piceid vizsgálatainak eredményei a 2007-es évjáratban

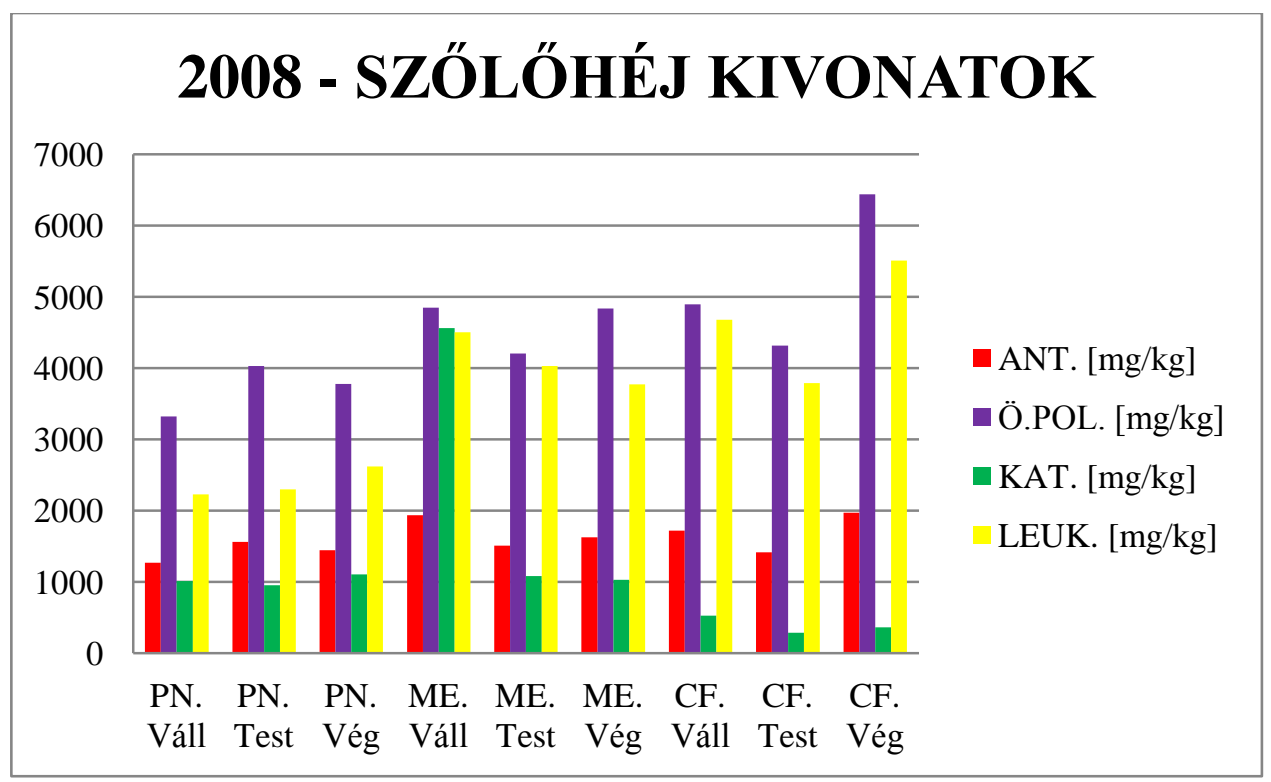

17. ábra: Szőlőhéjextraktumok vizsgálatának eredményei a 2008-as évjáratban 


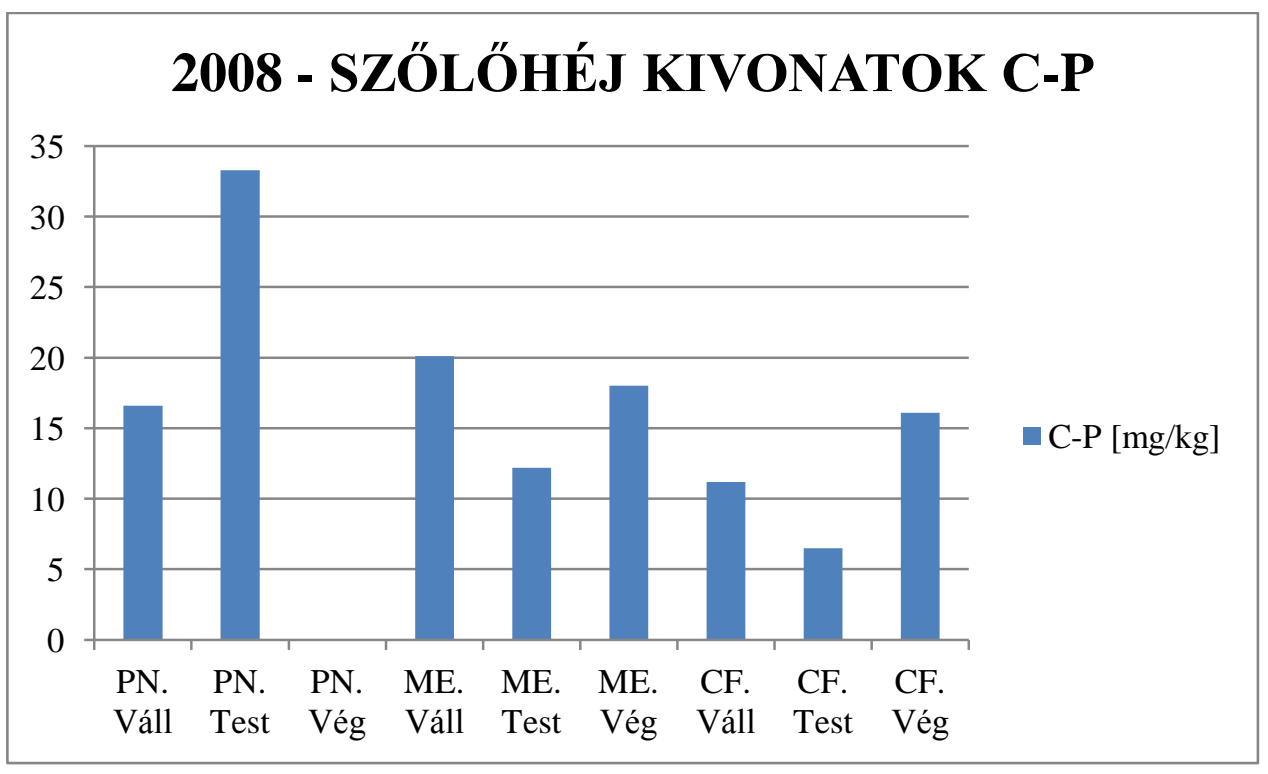

18. ábra: Szőlőhéjextraktumok cisz-piceid vizsgálatának eredményei a 2008-as évjáratban

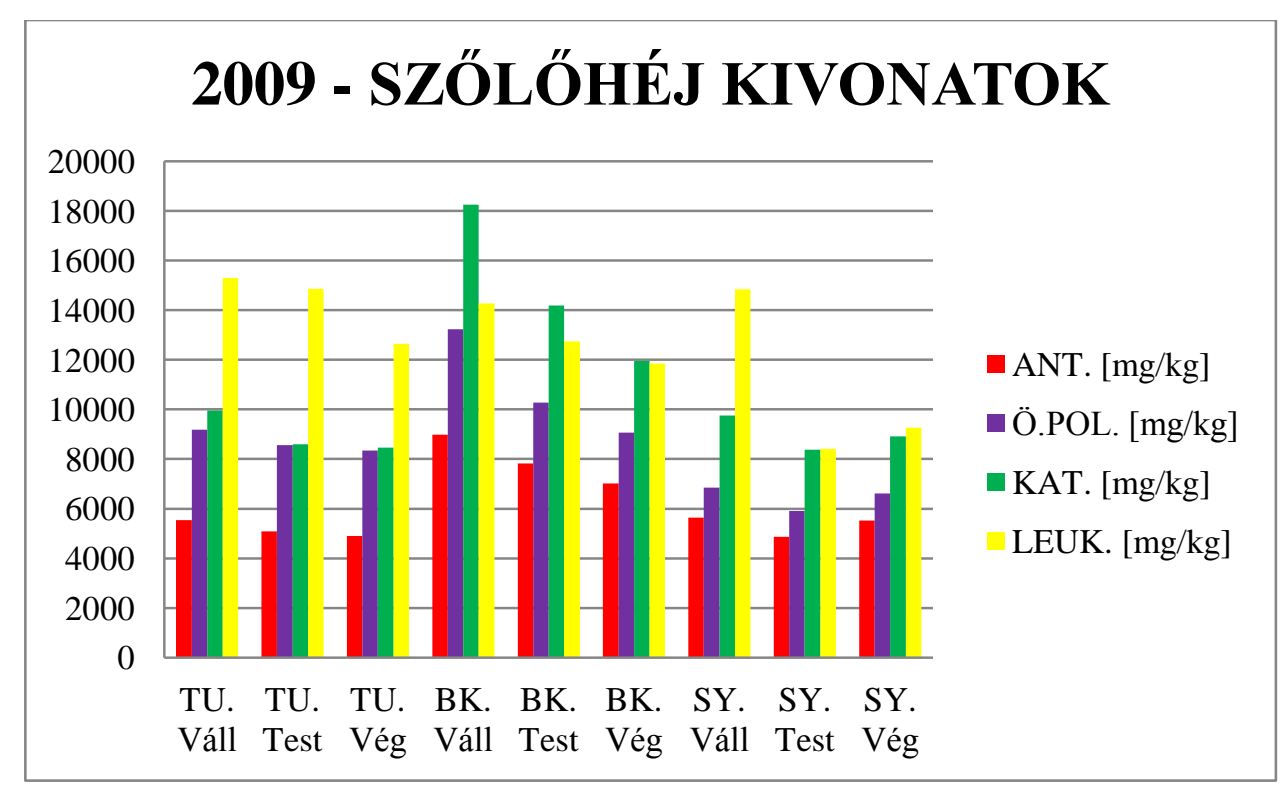

19. ábra: Szőlőhéjextraktumok vizsgálatának eredményei a 2009-es évjáratban 


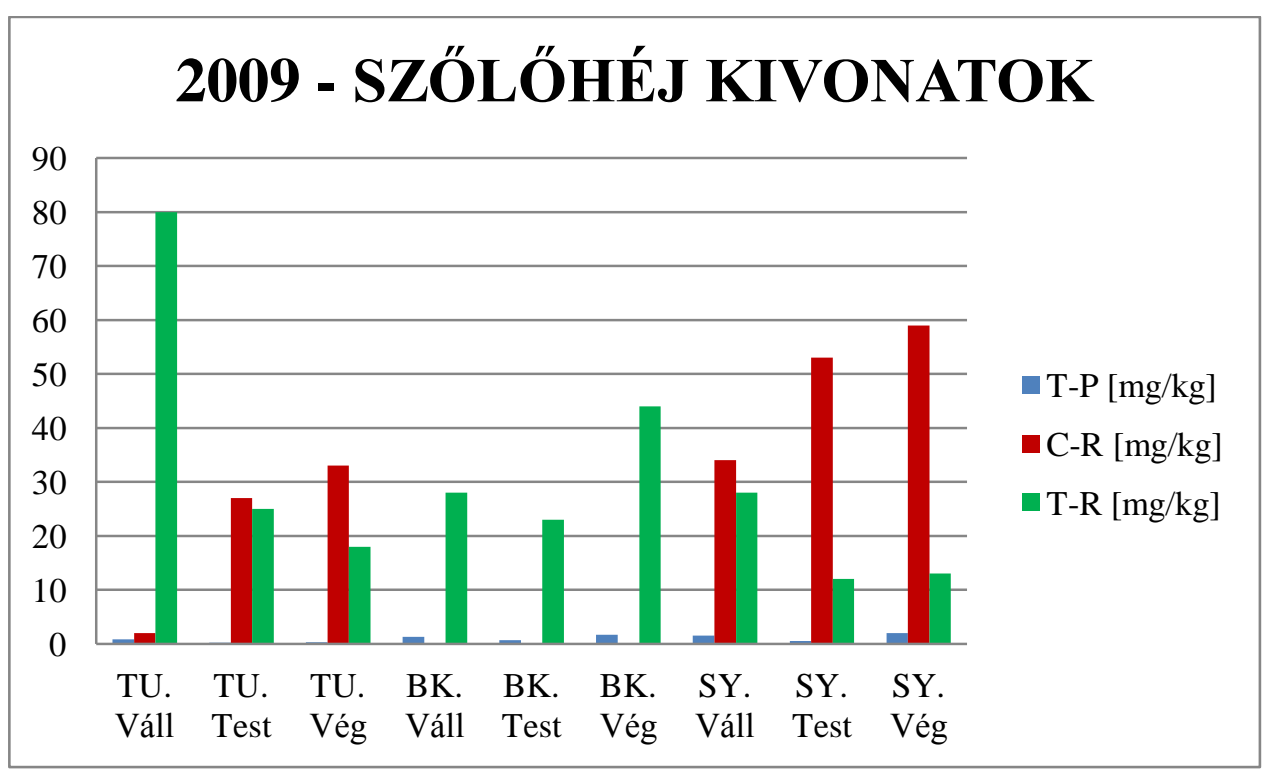

20. ábra: Szőlőhéjextraktumok transz-piceid, cisz- és transz-rezveratrol vizsgálatainak eredményei a 2009-es évjáratban

\subsubsection{Szőlőhéj extraktumok vizsgálata 2007-ben}

A 2007-es évjáratban három szőlőfajtát vizsgáltam: Blauburger, Kékfrankos és Zweigelt. Mind a három szőlőfajta esetében a mintavétel időpontja a teljes érettség állapotában történt. A vizsgálatok során a fürtöt három egyenlő részre osztottam, és fenolos vegyületeket vizsgáltam. A 21. és 22. ábrán a Blauburger fürtrészen belüli fenolos összetételének eloszlása látható a 2007-es évjáratban.

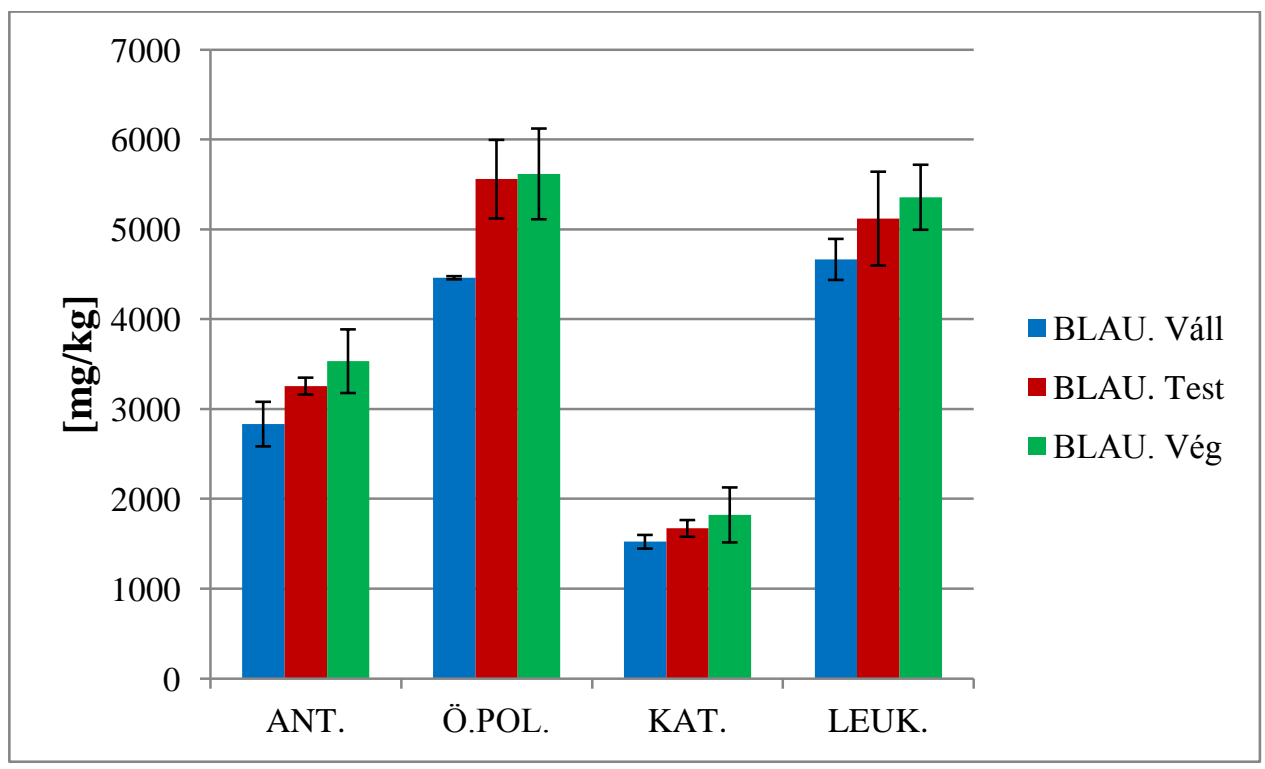

21. ábra: Blauburger fenolos vegyületeinek eloszlása a fürtrészeken belül a 2007-es évjáratban 


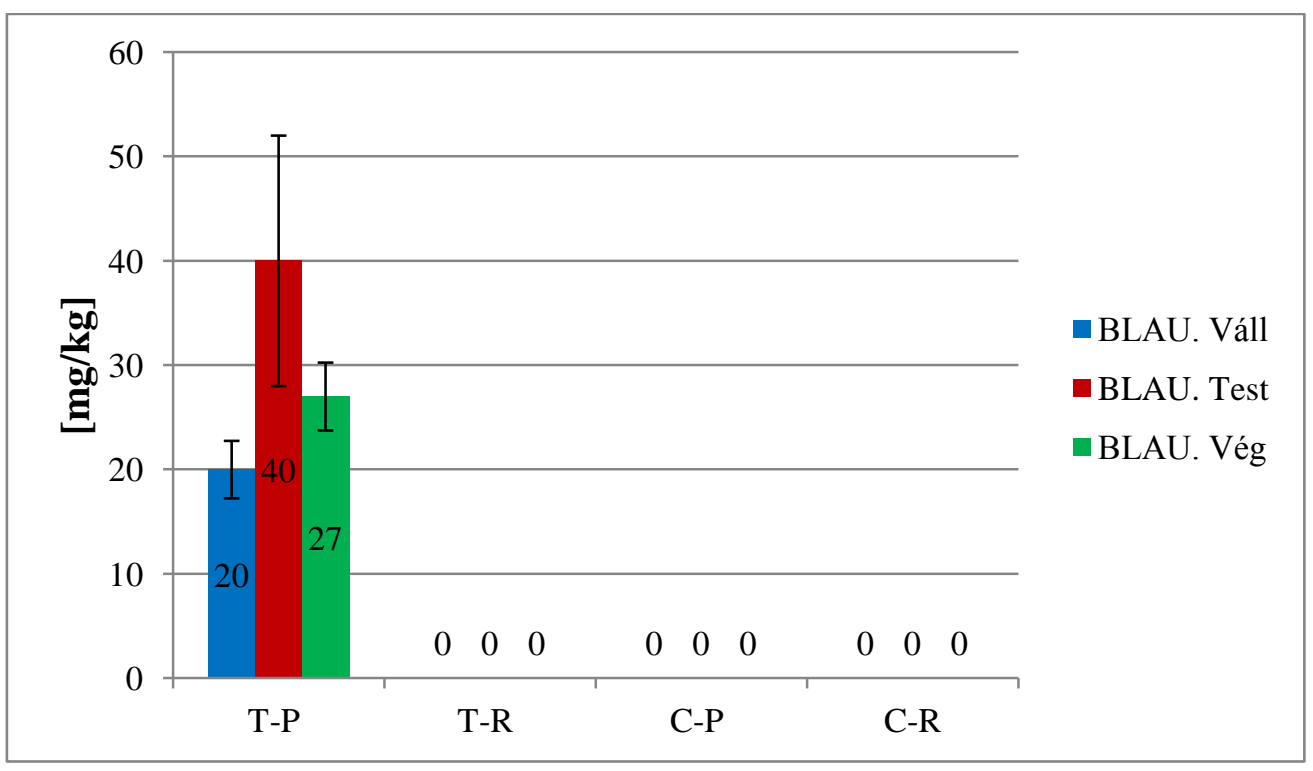

22. ábra: Transz-piceid fürtön belüli eloszlása a Blauburger szőlőfajtában, a 2007-es évjáratban

Az antocianin-vegyületek szempontjából a Blauburger szőlöfajtában a legmagasabb értéket a fürt vég részében mértem [3533 mg/kg héj], a legalacsonyabb értéket pedig a fürt váll részében [2833 $\mathrm{mg} / \mathrm{kg}$ héj]. Az antocianin-koncentráció fürtön belüli eloszlásánál szignifikáns eltérést mutatott ki a Tukey-teszt a váll és a vég között $(\mathrm{p}<0,05)$.

Az összespolifenol-koncentráció legmagasabb értéke a fürt vég részében volt detektálható [5618 $\mathrm{mg} / \mathrm{kg}$ héj], míg a legalacsonyabb eredmény a váll részében volt [4462 mg/kg héj]. A fürt középeső részén közel hasonló értéket mértem, mint a vég részben, a nagyobb különbség a váll és a vég részek között volt. Ennek ellenére a statisztikai kiértékelés szignifikanciát nem mutatott.

A Blauburger szőlöhéjextraktumainak katechintartalma 1523 és 1822 mg/kg héj koncentráció között változott. A legkisebb értéket megint a váll részében mértem, a legmagasabbat pedig a vég részében. A fürtrészek finomösszetételének tartalma között a statisztika nem mutatott ki szignifikáns eltérést a nagy szórások miatt.

A leukoantocianin-tartalmat illetően a Blauburger többi fenolos vegyületeihez hasonlóan a fürt vég részében mértem a legmagasabb értéket [5358 mg/kg héj], a legalacsonyabb mennyiséget pedig a váll részekben $[4666 \mathrm{mg} / \mathrm{kg}$ héj].

Megállapítható, hogy a 2007-es évjáratban a Blauburger szőlőfajtánál a fenolos vegyületek a fürtön belül leginkább a vég részben akkumulálódtak, a legalacsonyabb mennyiségben pedig a váll részében voltak mérhetőek. Szignifikáns eltérés az antocianin-vegyületek mennyiségében mutatkozott. 
A kromatográfiás vizsgálattal a sztilbén vegyületcsoporton belül a Blauburger szőlőfajtánál csak a transz-piceidet sikerült kimutatnom a szőlőhéjmintákban. Ez a tény az irodalmi állításoknak megfelel, hiszen a héjban többnyire a piceid forma van jelen, ami az élesztő enzimaktivitásának hatására az alkoholos erjedés során átalakul rezveratrollá. A transz forma a természetben előfordul, mely fény hatására cisz formává átalakulhat.

2007-ben a Blauburgerben a legmagasabb értéket a többi fenolos vegyülethez képest a fürt középső részén, a test részben mértem [40 mg/kg héj], míg a legalacsonyabb koncentrációban [20 mg/kg héj] a váll szegmensben volt kimutatható. Szignifikáns differencia a nagy szórás miatt nem volt kimutatható, annak ellenére, hogy a két fürtrész jelentősen eltér egymástól.

A 2007-es évjáratban a Kékfrankos fenolos vegyületeinek fürtön belüli eloszlását a 23. és 24 . ábra mutatja be.

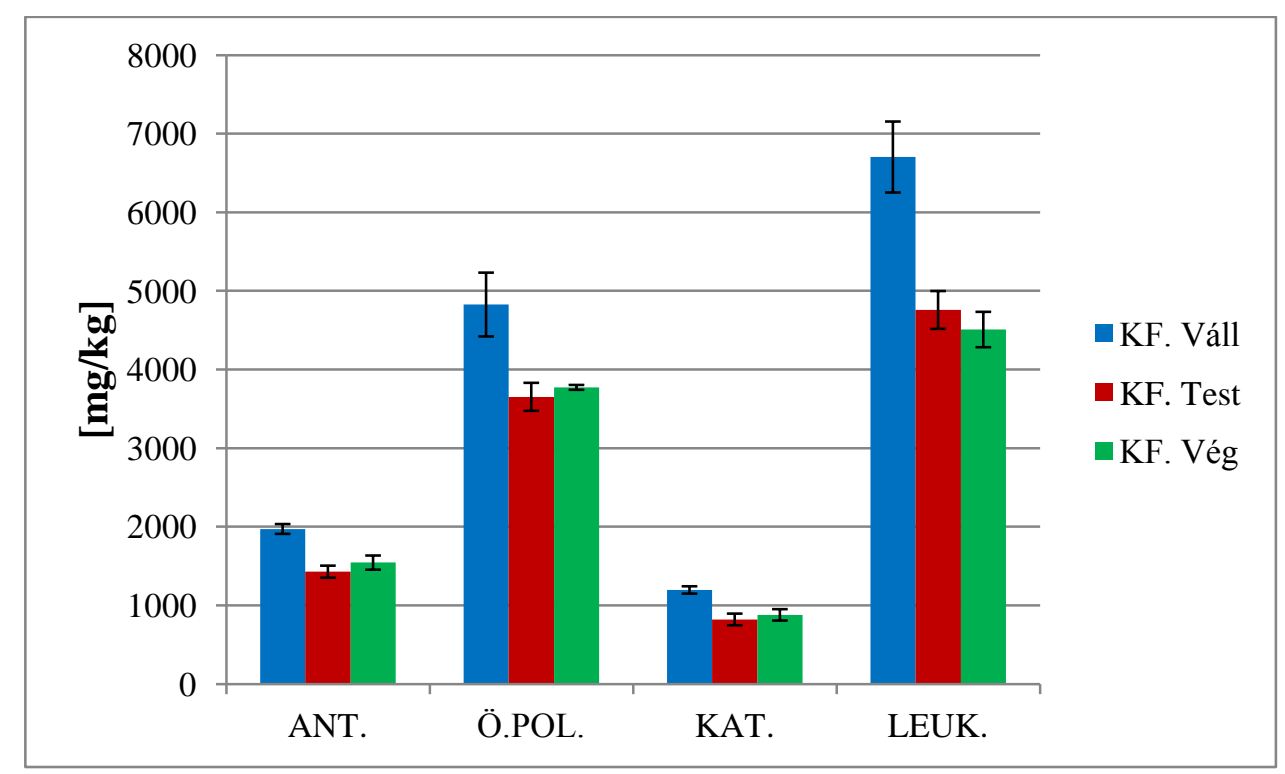

23. ábra: Kékfrankos szőlőfajta finomösszetételének eloszlás a fürtön belül a 2007-es évjáratban

A Kékfrankos szőlöfajta az Egri Bikavér alapja, egyik fő fajtája az Egri borvidéknek, ezért is nagyon fontos a fenolos vegyületek feltérképezése minőségi és mennyiségi szempontból.

Az antocianin-vegyületek fontos szerepet játszanak a kékszőlők, vörösborok színének kialakításában. Az érés kezdetén az antocianinok mennyisége emelkedést mutat, majd a fenolos érettség beálltakor egy stagnálás, majd pedig egy csökkenő tendencia figyelhető meg. Jelen fajtánál a 2007-es évjáratban a fürtön belül a legmagasabb mennyiségben a váll részében [1971 $\mathrm{mg} / \mathrm{kg}$ héj] volt kimutatható, míg a legalacsonyabb értéket pedig a vég részben [1543 mg/kg héj] mértem. A Tukey-teszt szerint szignifikáns differencia található a váll és a vég részek között. 
Az összespolifenol-koncentráció a fürt felső részében, azaz a vállban volt a legnagyobb mennyiségben [4826 mg/kg héj], míg a legalacsonyabb érték a középső részben, azaz a testben volt [3652 mg/kg héj]. Számottevő különbség van a váll és a vég részek között. A statisztikai elemzések során a normalitás sérült, ezért post hoc tesztet alkalmaztunk, melynél a két szegmens között a nagy szórás miatt szignifikáns különbség nem mutatható ki, annak ellenére, hogy kardinális mennyiségbeli különbség van az összes polifenolvegyületek tekintetében.

A katechinek monomer állapotban vannak jelen a szőlőhéjban, a későbbiekben belőlük épülnek fel a különböző fokú polimerizációs származékok. A borokban relevánsan érezhető vegyületek, ezért nagyon fontos már a szőlőben található mennyiségük. A Kékfrankos szőlőfajtánál a legnagyobb mennyiségben a fürt felső részében, a vállban [1195 mg/kg héj] sikerült kimutatni, a legalacsonyabb érték megint a középső részén [820 mg/kg héj] található.

A leukoantocianin-monomerek építőkövei a procianidineknek. A szőlöhéjban főként monomerként vannak jelen, de előfordulhatnak dimer, illetve trimer formában is. A fürt hossztengelye mentén való eloszlása tekintetében a leukoantocianin-monomerek csökkenő tendenciát mutatnak a váll-test-vég irányába. A legnagyobb mennyiségben a váll részben van jelen.

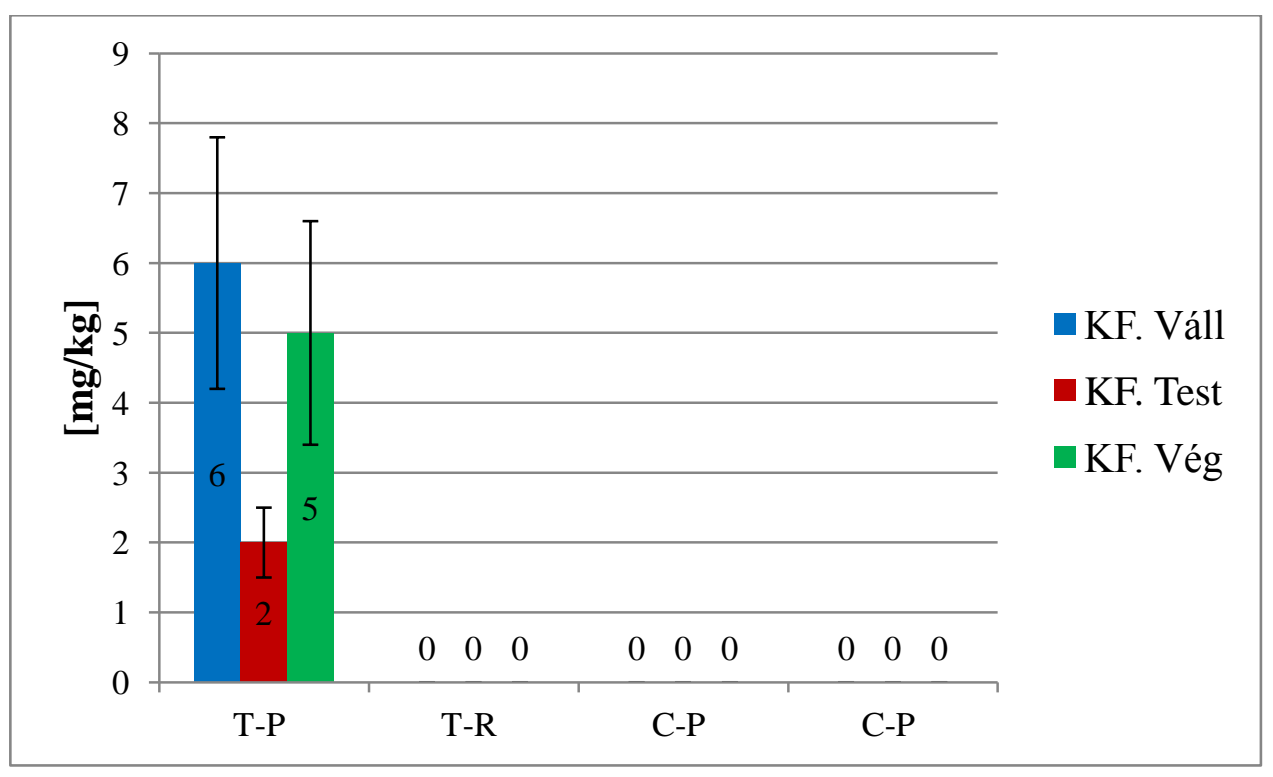

24. ábra: Kékfrankos szőlőfajta transz-piceid tartalma a fürtön belül a 2007-es évjáratban

A Kékfrankos szőlőhéjában detektálható transz-piceid a váll részében volt a legnagyobb mennyiségben. A legalacsonyabb értéket itt is a fürt középső részén mértem.

A 2007-es évjáratból származó Kékfrankos szőlőfajta élettanilag aktív vegyületeinek tekintetében a fürtön belül a váll részben koncentrálódtak a legnagyobb mennyiségben ezek a 
vegyületek. Ebből az évjáratból kiindulva a terméskorlátozási módszereken belül választhatjuk a fürtfelezést, vagy a fürttépést, ami minőségbeli javulást is eredményezhet, ugyanis nagyobb mennyiségben lokalizálódhatnak a fenolos vegyületek a váll részben.

A 2007-es évjáratból származó Zweigelt szőlőfajta fenolos komponenseit a 25. és 26. ábra mutatja be.

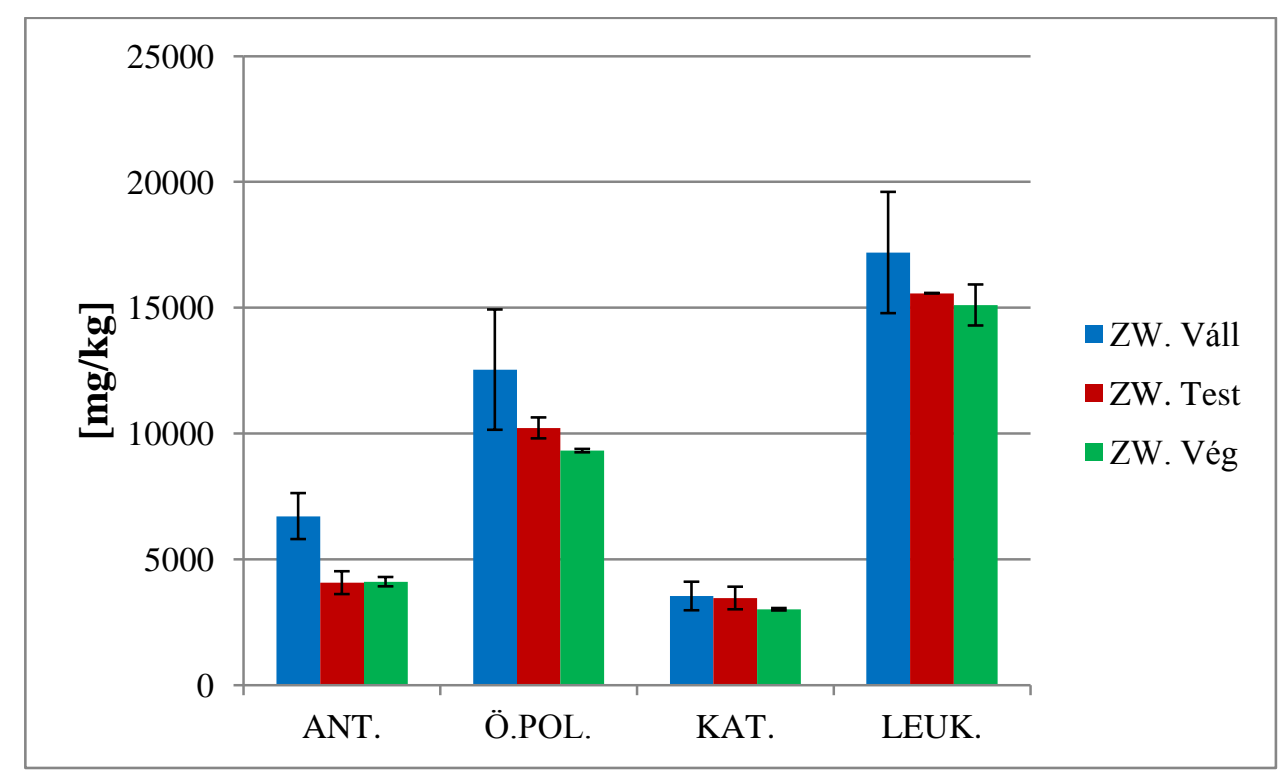

25. ábra: Zweigelt szőlőfajta fenolos összetétele a 2007-es évjáratban

A bogyóhéjminták antocianin-tartalma 4062 mg/kg héj és 6709 mg/kg héj koncentráció között változott. A legnagyobb mennyiségben a fürtön belül a váll részben sikerült kimutatni, míg a legalacsonyabb koncentrációt a középső részben. Lényegesen nagyobb mennyiségben lokalizálódnak az antocianin-vegyületek a Zweigelt váll részében, ennek ellenére a nagy szórás miatt nem alakult ki szignifikáns differencia a statisztika szerint.

Az összespolifenol-tartalom mennyiségi és minőségi szempontból ennél a fajtánál is a legnagyobb mennyiségben a váll részében volt kimutatható, és ennek értéke csökkenő tendenciát mutat a test-vég irányába. E szőlőfajta ebben az évjáratban igen kiemelkedően magas polifenol tartalommal bírt [12532 mg/kg héj]. A három szőlőfajta közül a Zweigelt fajtában a legmagasabb ez az érték a 2007-es évjáratban.

A szőlőhéjminták katechintartalma 3006 mg/kg héj és 3532 mg/kg héj koncentrációk között változott. A fürtön belül kardinális mennyiségbeli és minőségbeli különbségek ebben az évjáratban ennél a fajtánál nem voltak észlelhetőek a katechin komponens szempontjából. A legmagasabb értéket a váll részben mértem, míg a legalacsonyabb mennyiséget a fürt vég részében. 
2007-ben a Zweigelt fajta szőlőhéjextraktumaiban a leukoantocianin-koncentráció kiemelkedően magas volt a fürt váll részében $[17188 \mathrm{mg} / \mathrm{kg}$ héj]. A legalacsonyabb értéket a fürt alsó részében mértem. A statisztikai elemzéssel az eltérések ellenére szignifikáns különbséget nem mutatattam ki.

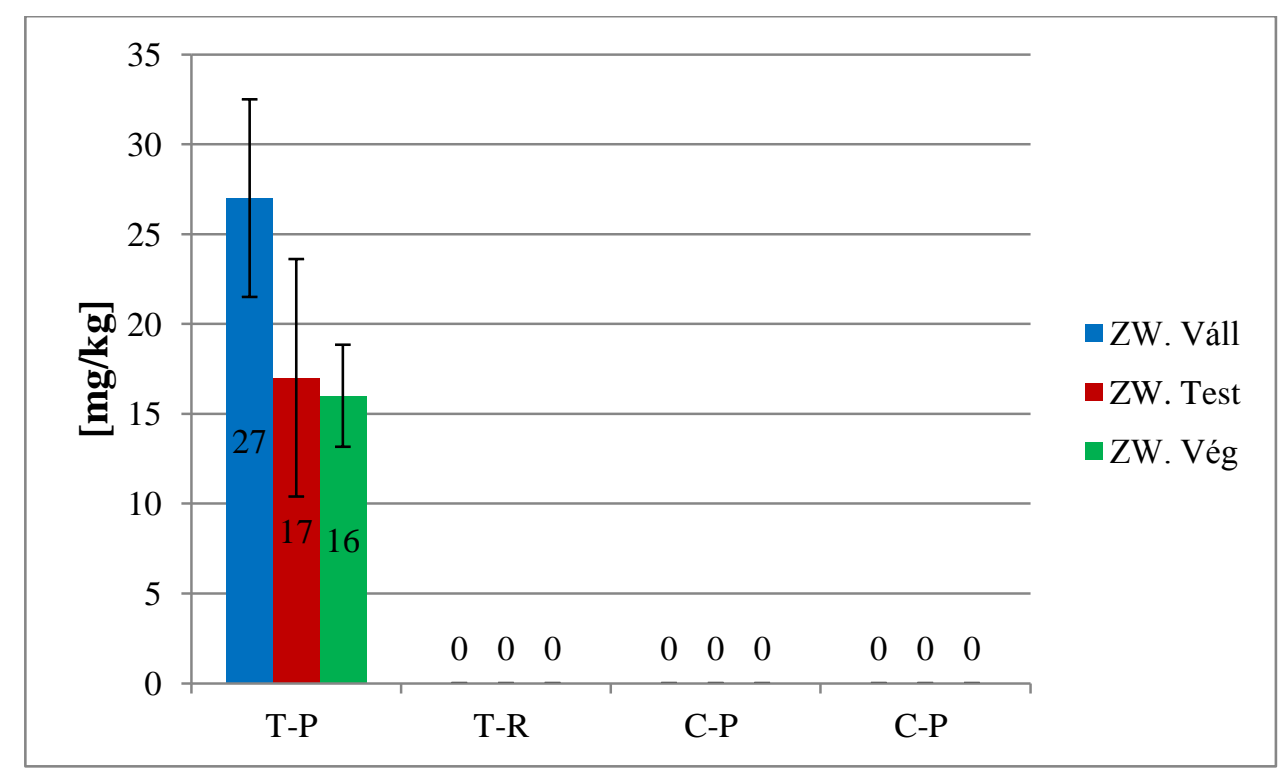

26. ábra: Transz-piceid fürtön belüli eloszlása a Zweigelt szőlőfajtában, a 2007-es évjáratban

A Zweigelt fajtában is a rezveratrol geometriai izomerje közül a transz-piceidet detektáltam. A legnagyobb mennyiségben itt is a váll részben sikerült kimutatni [27mg/kg héj]. A nagy mennyiségbeli különbségek ellenére szignifikáns eltérés nem volt kimutatható.

Megállapítható, hogy a 2007-es évjáratban a három szőlőfajta közül a fenolos vegyületek kettő szőlőfajta esetében (Kékfrankos és Zweigelt) a fürt felső részében, azaz a vállban akkumulálódtak a legnagyobb mennyiségben. A fajták között az élettanilag aktív vegyületek mennyiségbeli szempontjából különbségek voltak. A legmagasabb fenolos koncentrációkat a Zweigelt fajta hozta ebben az évjáratban. A MANOVA teszt alapján van szignifikáns eltérés a fajták között (Wilks $\lambda=0,004, \mathrm{p}<0,001$ ), tehát más mennyiségben és minőségben vannak jelen a fenolos vegyületek a szőlöhéjextraktumokban. A 2007-es évjáratban a különbségek ellenére a fürtön belüli eloszlások között nincs szignifikáns differencia (Wilks $\lambda=0,411, p=0,168$ ) egyik fajtánál sem (BLAU, KF, ZW) az élettanilag aktív vegyületek szempontjából, ugyanis a normalitás sérült a kiugró értékek miatt, a szórások pedig magasak voltak. Az antocianinkomponenseknél a Tukey-teszt alapján azonban szignifikáns eltérés alakult ki.

\subsubsection{Szőlőhéj extraktumok vizsgálata 2008-ban}

A 2008-es évjáratban három szőlőfajtát vizsgáltam: Pinot noir, Merlot és Cabernet franc. Mind a három szőlőfajta esetében a mintavétel időpontja a teljes érettség állapotában történt. A 
vizsgálatok során a fürtöt matematikailag három egyenlő részre osztottam és az élettanilag aktív vegyületeket vizsgáltam. A 27. és 28. ábrán a Pinot noir fürtön belüli fenolos összetételének eloszlása látható a 2008-es évjáratban.

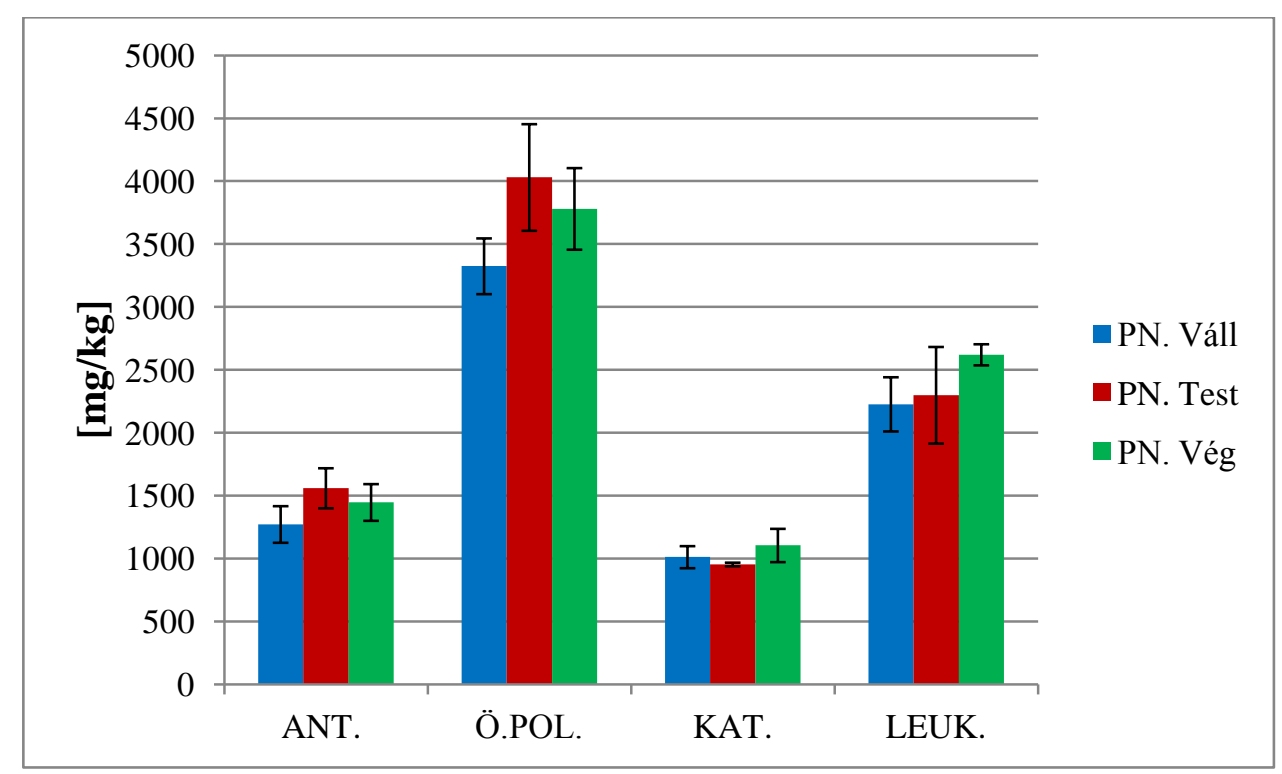

27. ábra: Pinot noir szőlőfajta fenolos vegyületeinek eloszlása a fürtön belül a 2008-as évjáratban

A Pinot noir szőlőfajta antocianin-koncentrációja a 2008-as évjáratban $1271 \mathrm{mg} / \mathrm{kg}$ héj és 1559 $\mathrm{mg} / \mathrm{kg}$ héj koncentrációk között mozgott. A legmagasabb mennyiséget a fürt test részében sikerült kimutatni. Általánosságban elmondható, hogy ez a Pinot noir-klón, mellyel dolgoztam, egy kicsit halványabb színnel rendelkezik a többi klónhoz képest, ebböl is következik az alacsonyabb antocianin-tartalom. A legalacsonyabb értéket a váll részben mértem.

Az összespolifenol-koncentráció esetében is a fürt test részében mértem a legnagyobb mennyiséget [4030 mg/kg héj]. A legalacsonyabb érték a váll részben volt [3324 mg/kg héj]. A statisztikai kiértékelés a Tukey-teszt szerint szignifikanciát mutatott ki a test és a váll között.

A Pinot noir szőlőhéjában található katechinmonomerek legmagasabb értékét [1104 mg/kg héj] a fürt vég részében mértem, míg a legalacsonyabb mennyiség a test részben volt kimutatható. Jelentős különbségek ebben az évjáratban a katechin komponens szempontjából a fürtön belüli eloszlások között nem volt.

A különböző fürtszegmensekben a Pinot noir szőlőfajtánál $2226 \mathrm{mg} / \mathrm{kg}$ héj és $2620 \mathrm{mg} / \mathrm{kg}$ héj leukoantocianin értékeket mértem. A váll-test-vég felé növekvő tendenciát mutat a leukoantocianin-tartalom. A statisztikai kiértékelés alapján szignifikáns eltérés volt felfedezhető a vég-váll és a vég-test között. 


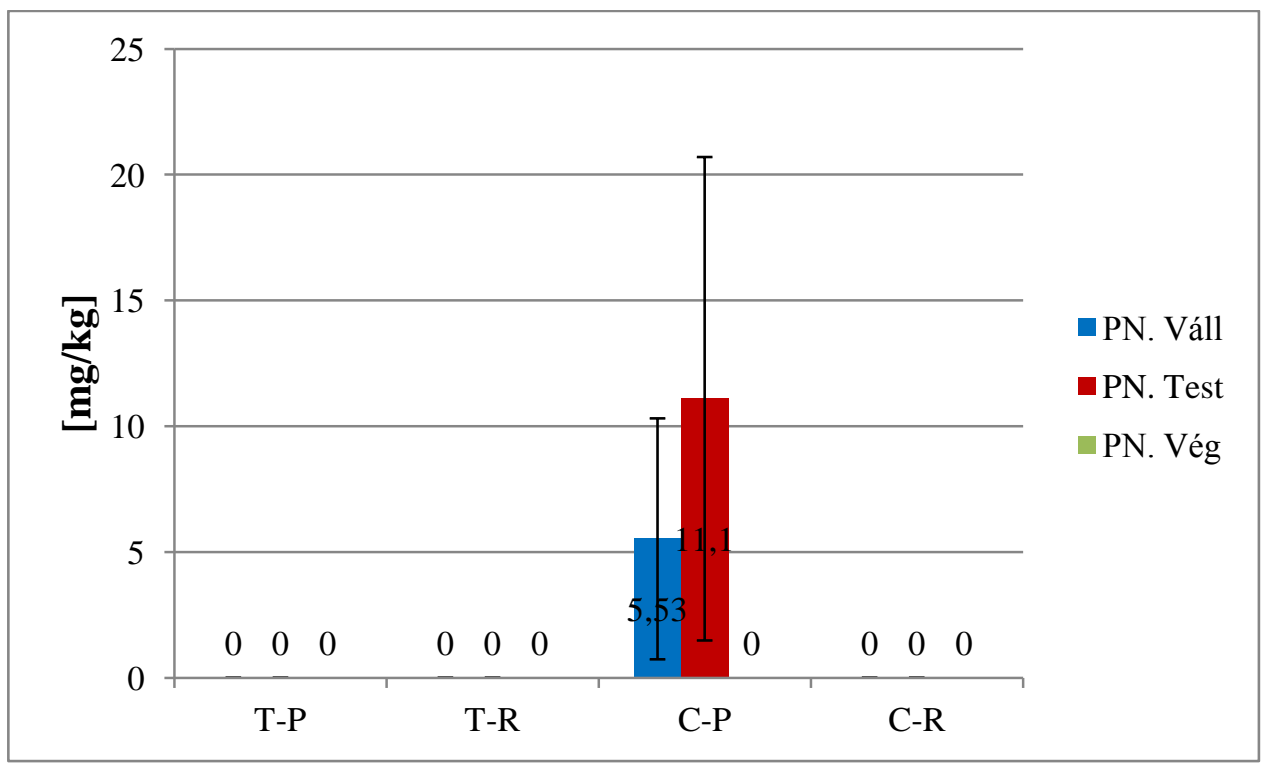

28. ábra: Pinot noir cisz-piceid tartalma a fürtön belül a 2008-as évjáratban

Az előző évjáratban is a kromatográfiás vizsgálatok során a rezveratrol összetevők közül a piceid formát sikerült detektálni. A természetben a transz forma fordul elö, 2008-ban a cisz formát sikerült kimutatni. A Pinot noir fajtánál a test és a váll részben mértem a cisz-piceideket, a vég részben nem tudtam detektálni. A test rész magasabb cisz-piceid tartalommal bírt, mint a váll rész.

A Merlot szőlőfajta élettanilag aktív vegyületeit a 2008-as évjáratban a 29. és 30. ábra szemlélteti.

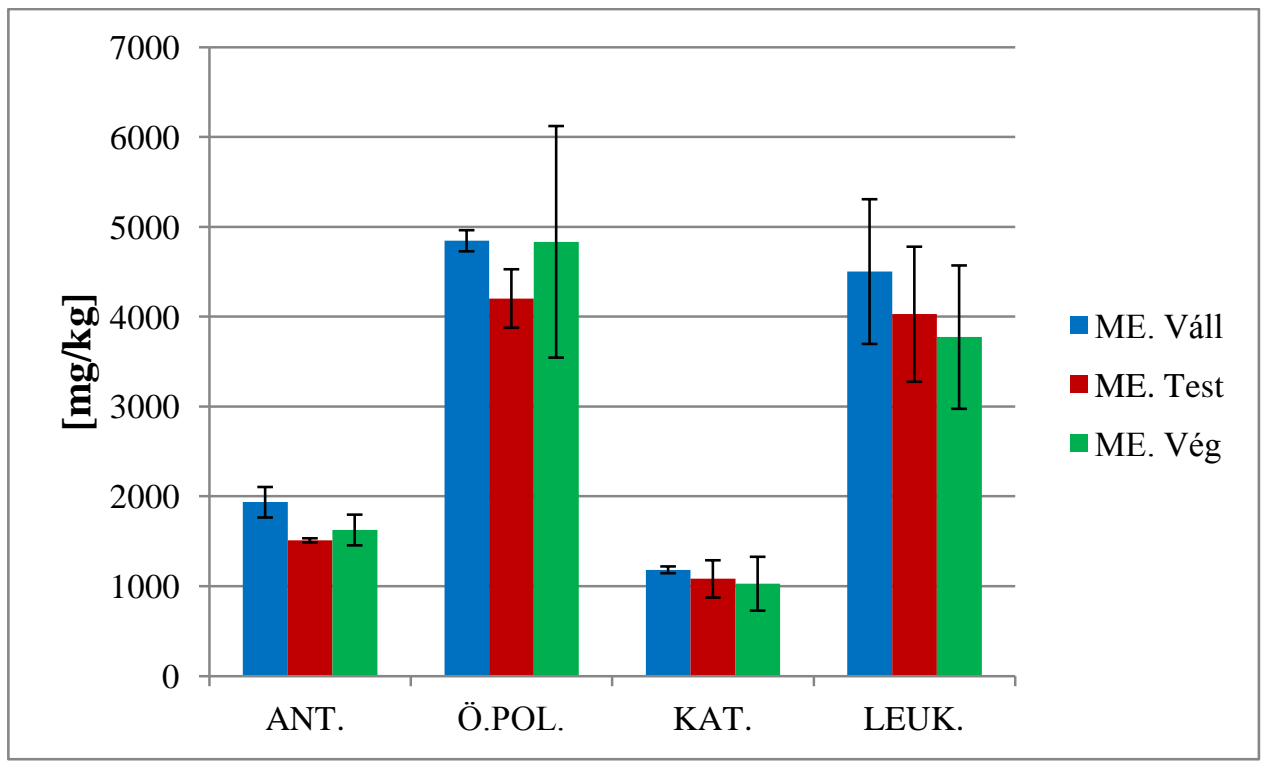

30. ábra: Merlot szőlőfajta héjában található fenolos vegyületek a 2008-as évjáratban 
A Merlot szőlőfajtánál az antocianin értékek magasabbak voltak, mint a Pinot noir fajtánál. A legmagasabb koncentrációt a fürtön belül a váll részben mértem [1935 mg/kg héj], míg a legalacsonyabb érték a test részben [1511 mg/kg héj] volt.

$\mathrm{Az}$ összes polifenol koncentráció a fürt felső részében, azaz a vállban volt a legnagyobb mennyiségben [4846 mg/kg héj], viszont szinte azonos koncentrációt mértem a fürt vég részében is [4834 mg/kg héj]. A statisztika szignifikáns különbséget mutatott. A test részben $4203 \mathrm{mg} / \mathrm{kg}$ héj mennyiséget sikerült kimutatni. A szegmenseken belül nagy különbségek nem voltak mennyiségi szempontból.

A katechintartalom a váll részben [4564 mg/kg héj] a legnagyobb a Merlot fajtánál a 2008-as évjáratban. A váll és a fürt többi része [test: $1081 \mathrm{mg} / \mathrm{kg}$ héj; vég: $1028 \mathrm{mg} / \mathrm{kg}$ héj] között jelentős a különbség. A normalitás sérült, magas a szórás, emiatt szignifikáns differencia nem mutatható ki a szembetünő különbségek ellenére.

A Merlot bogyóhéjak leukoantocianin-tartalma a vállban a legnagyobb [4503 mg/kg héj], ezután következik a test és a vég, tehát itt is csökkenő tendenciát figyelhetünk meg. Az ANOVA alapján szignifikáns különbség figyelhető meg.

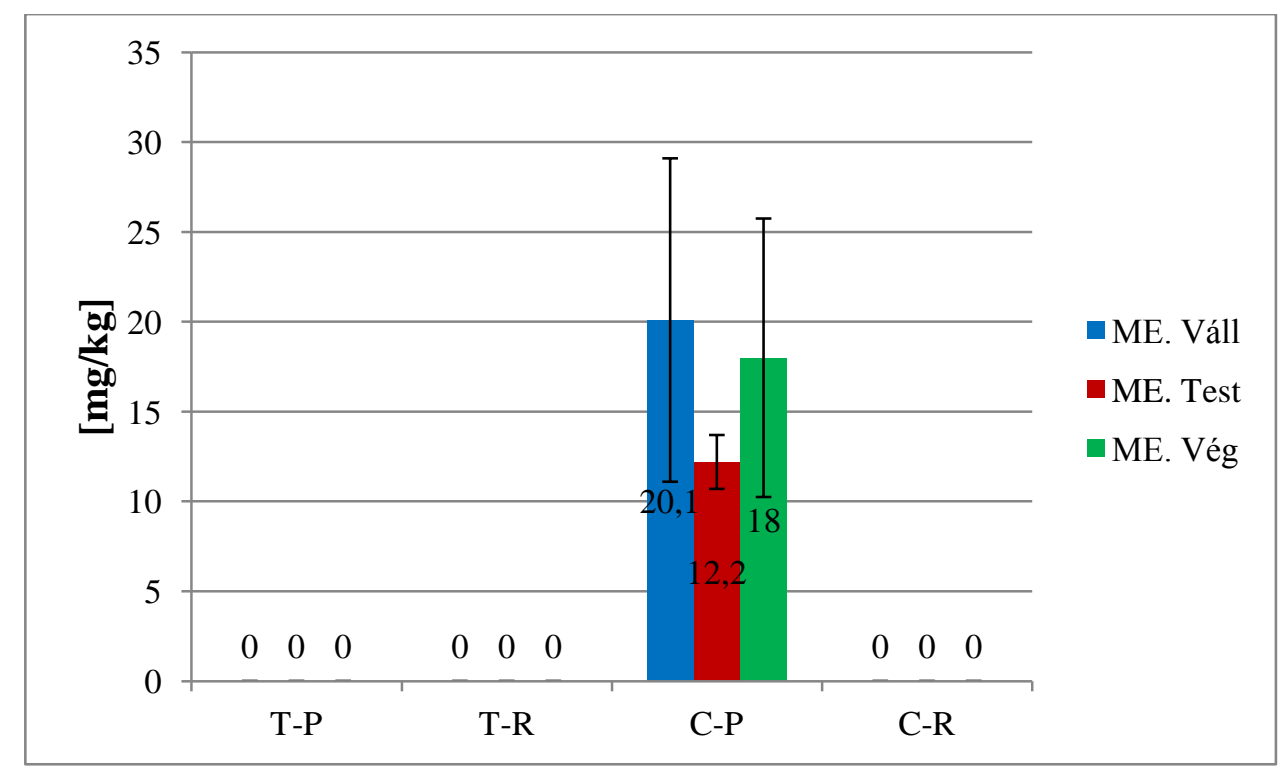

30. ábra: Cisz-piceid alakulása a Merlot szőlőfajtában a 2008-as évjáratban

A 2008-as évjáratban a Merlot szőlőfajtában is kromatográfiásan a cisz-piceidet detektáltam. A fürtön belül a vállban akkumulálódtak a legnagyobb mennyiségben, majd a vég részben, végül a testben. A mért értékek átlagosnak mondhatóak.

A 2008-as évjárat harmadik vizsgált fajtája a Cabernet franc, melynek fenolos eredményeit a 31. és 32. ábra szemlélteti. 


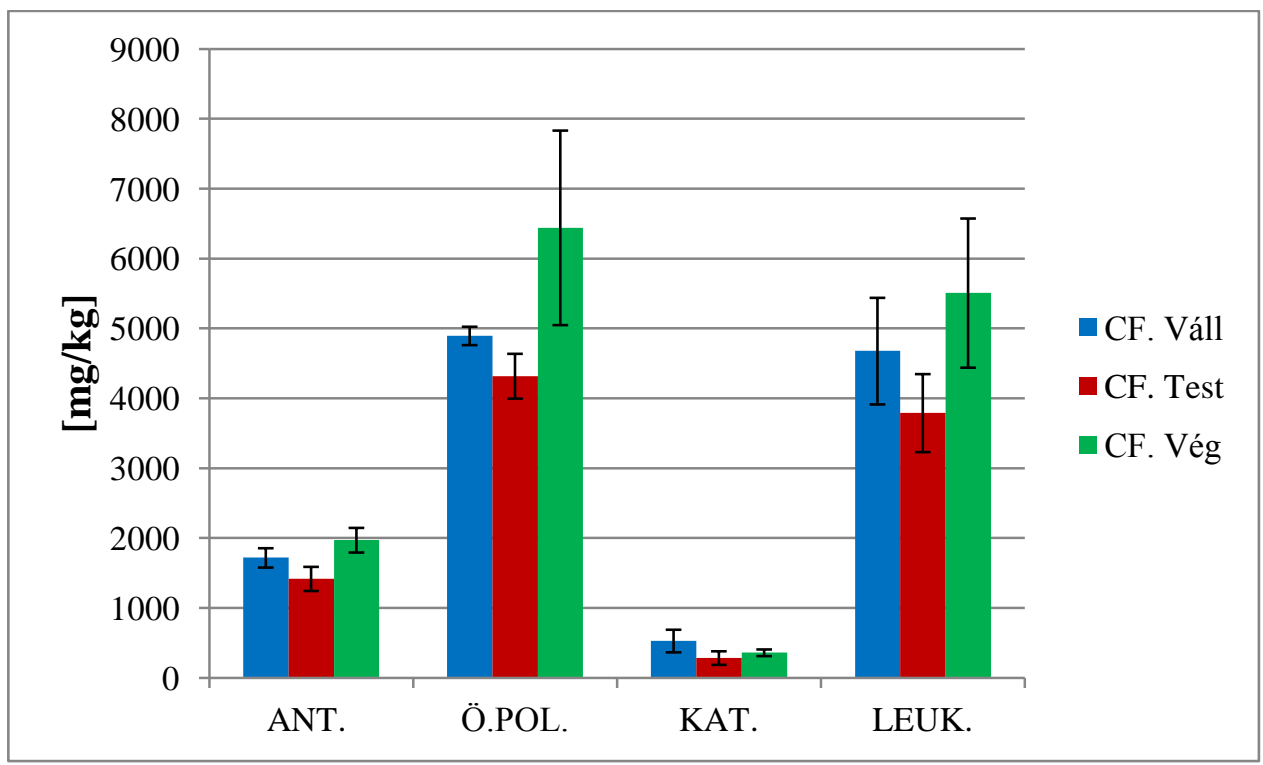

31. ábra: Cabernet franc fenolos komponensei a fürtön belül a 2008-as évjáratban

A Cabernet franc szőlőfajta esetében a fenolos vegyületek a katechintartalom kivételével a fürt vég részében lokalizálódnak. A második legnagyobb mennyiségben a középső részen, majd pedig a vállban voltak mérhetőek.

Az antocianin-tartalom mennyisége ebben az évjáratban a Merlot fajtával közel azonos. A Pinot noir szőlőfajtánál magasabb. A Cabernet franc fajtánál a legmagasabb érték $1971 \mathrm{mg} / \mathrm{kg}$ héj volt. Az összespolifenol-tartalomnál kiugróan magas értékeket mértem a vég részben $[6442 \mathrm{mg} / \mathrm{kg}$ héj]. A nagymértékủ eltérések ellenére a statisztika szignifikáns differenciát nem mutatott ki.

A katechintartalom a váll részben volt a legnagyobb, a mért eredmények a publikációkban szereplő korábban mért átlagokkal megegyeznek.

A leukoantocianin-monomerek a Cabernet franc szőlőfajtában a vég részben voltak a legnagyobb mennyiségben. A leukoantocianinok a legérezhetőbb vegyületek közé tartoznak, fanyarságban, húzósságban nyilvánul meg érzékszervi hatásuk, különösen ennél a fajtánál. Ez is bizonyítja, hogy ebben az évjáratban a három fajta közül a Cabernet franc szőlőfajtának volt a legmagasabb leukoantocianin-tartalma [5508 mg/kg héj]. 


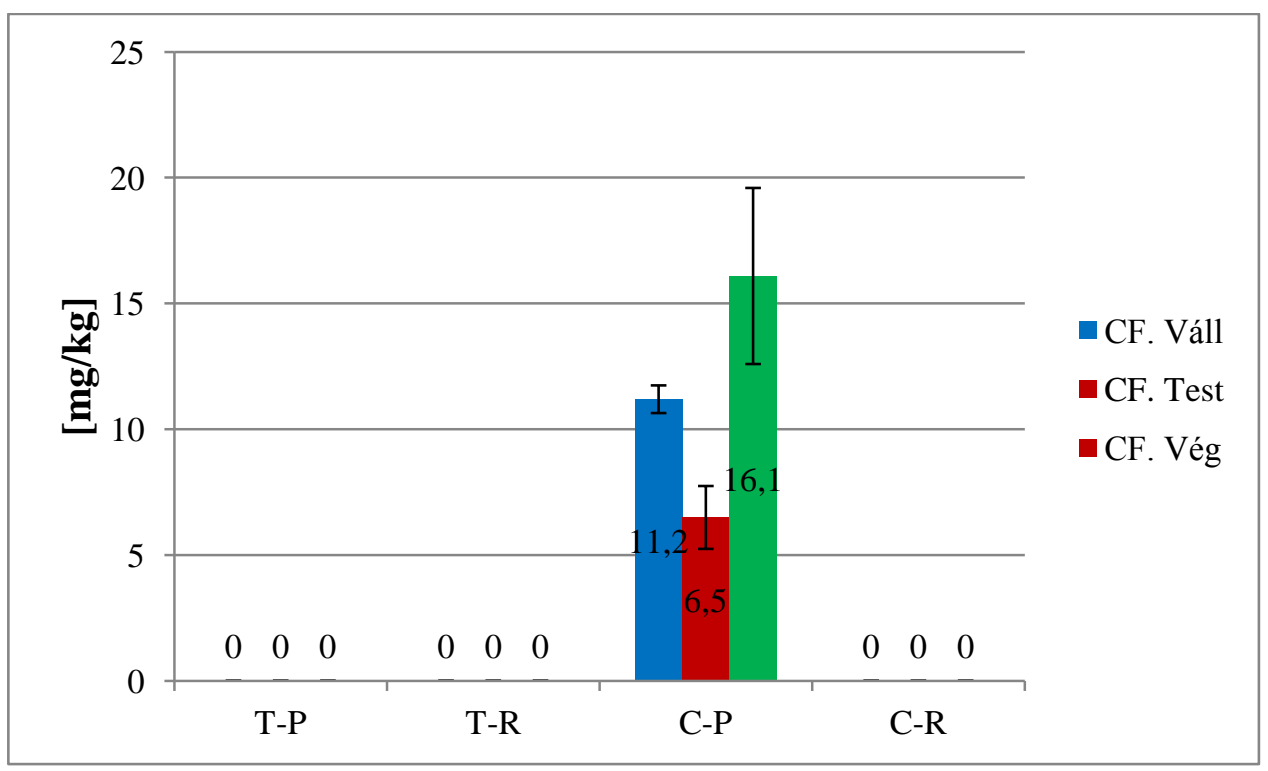

32. ábra: Cisz-piceid alakulása a Cabernet franc szőlőfürtben a 2008-as évjáratban

A bogyóhéj extraktumok kromatográfiás vizsgálatával a Cabernet franc mintákban a cisz-piceid vegyületet sikerült kimutatni. Ennél a fajtánál, úgy, mint a többi fenolos vegyületnél is, a ciszpiceid a vég részben akkumulálódott a legnagyobb mennyiségben. A mért értékek megegyeznek az irodalmi adatokkal.

A 2008-as évjáratban a fenolos vegyületek mennyiségi szempontból mind a három fajtánál különböző fürtrészben halmozódtak fel. A Pinot noir fajtánál zömében a középső részen, azaz a fürt test részében voltak nagyobb mennyiségben kimutathatóak az élettanilag aktív vegyületek, a Merlot szőlőfajtánál a váll részben emelkedtek ki nagyobb minőségben a vegyületek, míg a Cabernet franc fajtánál a fürt csúcsában, azaz a vég részben voltak nagyobb mennyiségben. Ebben az évben megállapítható, hogy az évjárathatás nem befolyásolja az élettanilag aktív vegyületek fürtön belül való feldúsulását, mindegyik fajtánál más és más. A statisztika a minőségi paramétereken belül az összes polifenolnál és a leukoantocianinnál mutatott ki szignifikáns differenciát. A fajták között a fenolos vegyületek tekintetében is szignifikáns különbség alakult ki.

\subsubsection{Szőlőhéjextraktumok vizsgálata 2009-ben}

A 2009-es évjáratban három szőlőfajtát vizsgáltam: Turán, Bíbor kadarka és Syrah. Ezt a három szőlőfajtát ettől az évtől kezdve lehet az Egri Bikavérbe házasítani. Mind a három szőlőfajta esetében a mintavétel időpontja a teljes érettség állapotában történt. A vizsgálatok során a fürtöt matematikailag három egyenlő részre osztottam, és az élettanilag aktív vegyületeket vizsgáltam. A 33. és 34. ábrán a Turán fürtön belüli fenolos összetételének eloszlása látható a 2009-es évjáratban. 


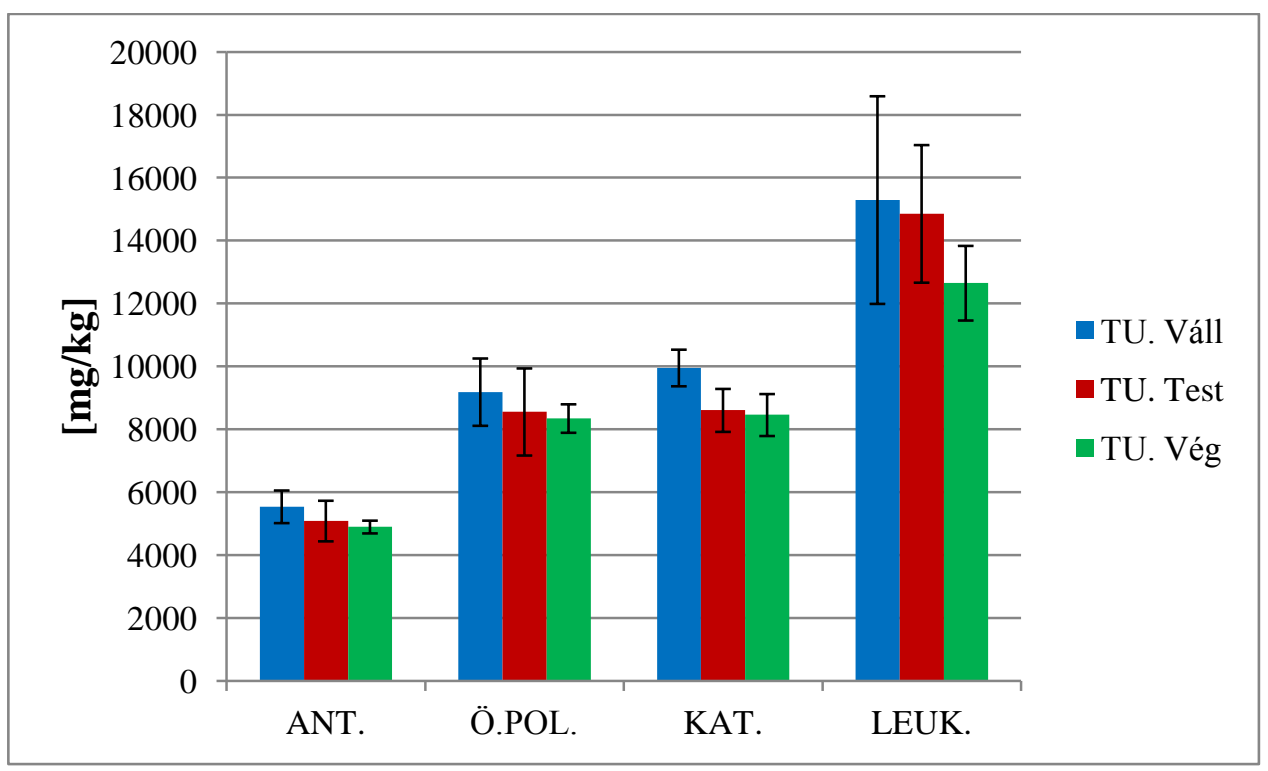

33. ábra: Turán szőlőfajta fürtön belüli fenolos vegyületeinek eloszlása a 2009-es évjáratban

A Turán bogyóhéjextraktumában mért legmagasabb antocianin-érték a vállban található, majd a fürtön lefelé haladva csökkenő tendenciát figyelhetünk meg. A Turán szőlőfajtában mért antocianin-vegyületek mennyisége nagymértékben kiemelkedik a többi fajta közül, ugyanis nagyon magas értékkel bír ez a szőlőfajta. A legmagasabb érték 5538 mg/kg héj. Ez az érték a fajta sajátosságának is köszönhető, ugyanis festőlevü fajta.

Az összespolifenol-tartalom szempontjából a legmagasabb értéket a váll részben $[9185 \mathrm{mg} / \mathrm{kg}$ héj], míg a legalacsonyabb koncentrációt a vég részben [8345 mg/kg héj] mértem.

A bogyóhéjminták katechintartalma $8457 \mathrm{mg} / \mathrm{kg}$ héj és $9954 \mathrm{mg} / \mathrm{kg}$ héj koncentráció között változott. A legkisebb értéket a fürt vég részében mértem, míg a legmagasabb érték itt is a váll részben volt. A statisztikai kiértékelés a különbségek ellenére sem mutatott ki szignifikáns differenciát.

A Turán szőlőfajta borára jellemző a fanyarság, enyhe húzósság is, de mindez harmóniában van a többi vegyülettel. A leukoantocianin az egyik vegyület, ami ezekért felel. Már a szőlőben kiemelkedően magas koncentrációkat mértem ebben az évjáratban ennél a fajtánál. A legmagasabb leukoantocianin-koncentráció a váll részben [15294 mg/kg héj] volt, míg a legalacsonyabb a vég részben [12649 $\mathrm{mg} / \mathrm{kg}$ héj]. 


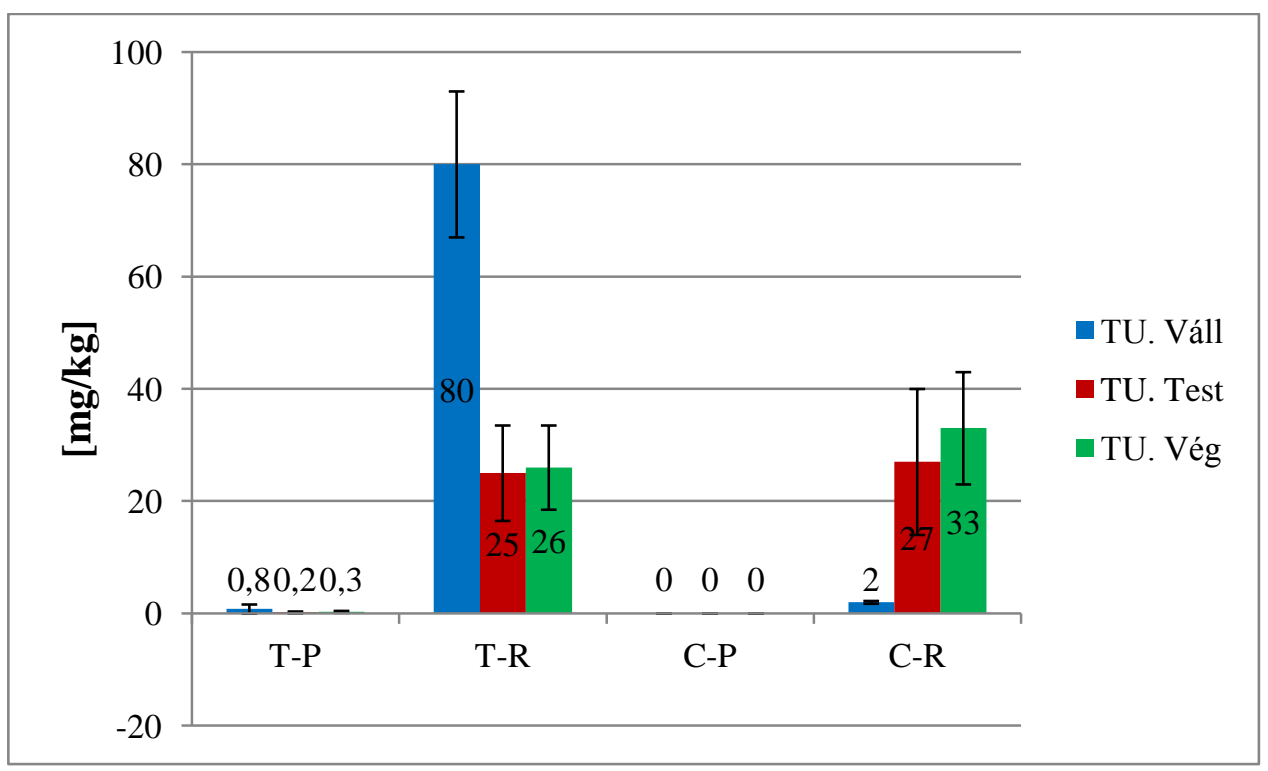

34. ábra: Sztilbén vegyületek eloszlása a Turán szőlőfajta fürtjén belül a 2009-es évjáratban

A szőlőhéj extraktumok kromatográfiás vizsgálatával három különböző rezveratrol összetevőt, transz-piceidet, transz-rezveratrolt és cisz-rezveratrolt sikerült kimutatnom a különbözö fürtzónákban. Már az előző évjáratokban említettem, hogy a héjban zömében a piceid-forma van jelen, ami az erjedés során rezveratrollá alakulhat. A 2009-es évjáratban a szőlőhéjban transzrezveratrolt is tudtam detektálni, ami feltételezhetően a $\beta$-glükozidáz aktivitás eredménye. A transz-piceid és a transz-rezveratrol a váll részben akkumulálódott a legnagyobb mennyiségben, míg a cisz-rezveratrol a vég részben. A fürtrészek tekintetében szignifikáns eltérést a transzrezveratrol koncentrációknál mutatott ki a statisztika.

A szintén festőlevű Bíbor kadarka fenolos összetételét a 35. és 36. ábra szemlélteti.

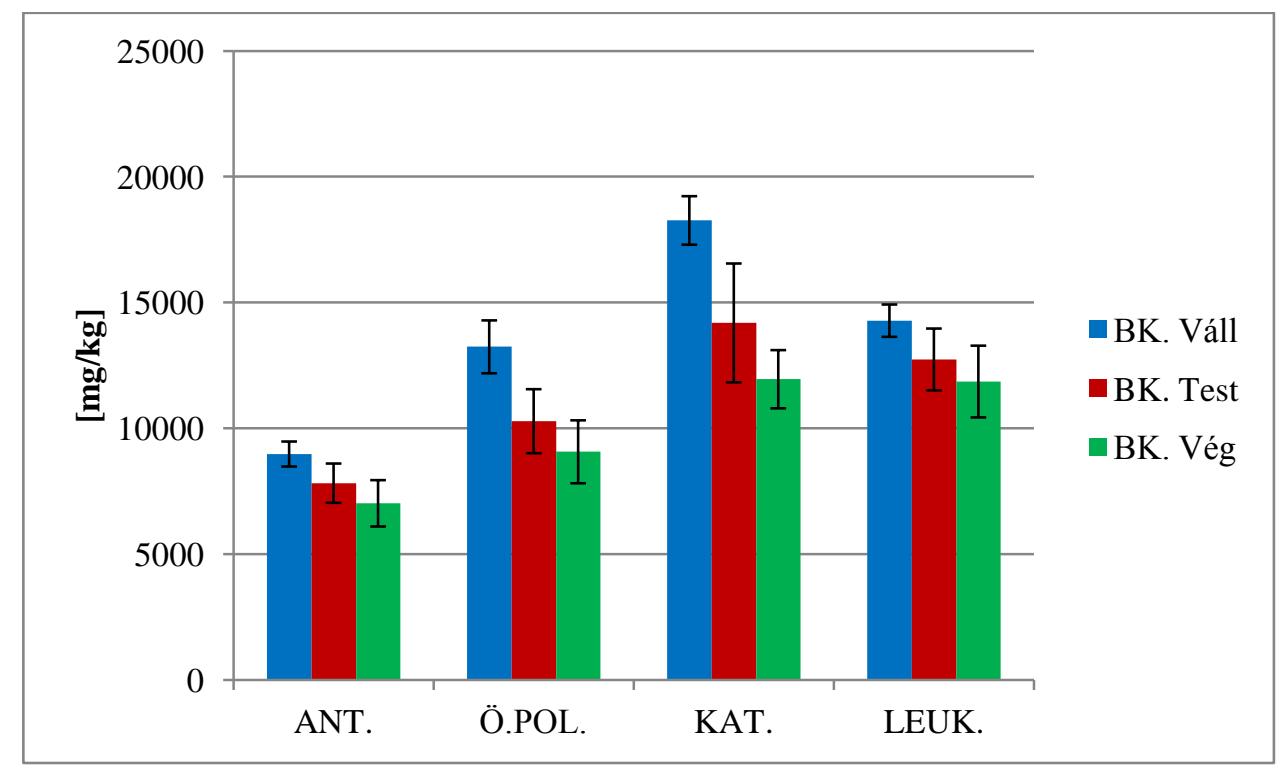

35. ábra: Bíbor kadarka fenolos összetevőinek alakulása a fürtön belül a 2009-es évjáratban 
A Turánhoz hasonlóan az antocianin-koncentráció mennyiségi szempontjából a Bíbor kadarka is kiemelkedő szőlőfajta. A legmagasabb értéket a váll részében [8978 mg/kg héj] mértem, a legalacsonyabb érték pedig a vég részben $[7018 \mathrm{mg} / \mathrm{kg}$ héj] volt kimutatható. Az antocianintartalom jóval magasabb az előző fajtához képest.

A szőlőhéjminták összespolifenol-tartalma 9066 mg/kg héj és 13239 mg/kg héj koncentrációk között mozgott. Nagymértékben kiemelkednek ezek az értékek a többi Egri Bikavért adó szőlőfajtához képest. Itt is a váll részben halmozódtak fel nagyobb mennyiségben a polifenol vegyületek.

A legkisebb átlagos katechinkoncentrációt a Bíbor kadarka vég részében [11952 mg/kg héj], a legmagasabbat pedig a váll részében [18264 mg/kg héj] mértem. Itt is egy csökkenő tendencia figyelhető meg a fürtrészen belül.

A Bíbor kadarka fürtön belüli szegmenseiben a kivonatokban a leukoantocianin értékek 11860 mg/kg héj és $14279 \mathrm{mg} / \mathrm{kg}$ héj koncentrációk között mozogtak. Jelentős különbségek a fürtön belül nincsenek, viszont a mért értékek magasabbak a többi fajtához képest. Nagy valószínűséggel az évjárathatásnak köszönhető ez.

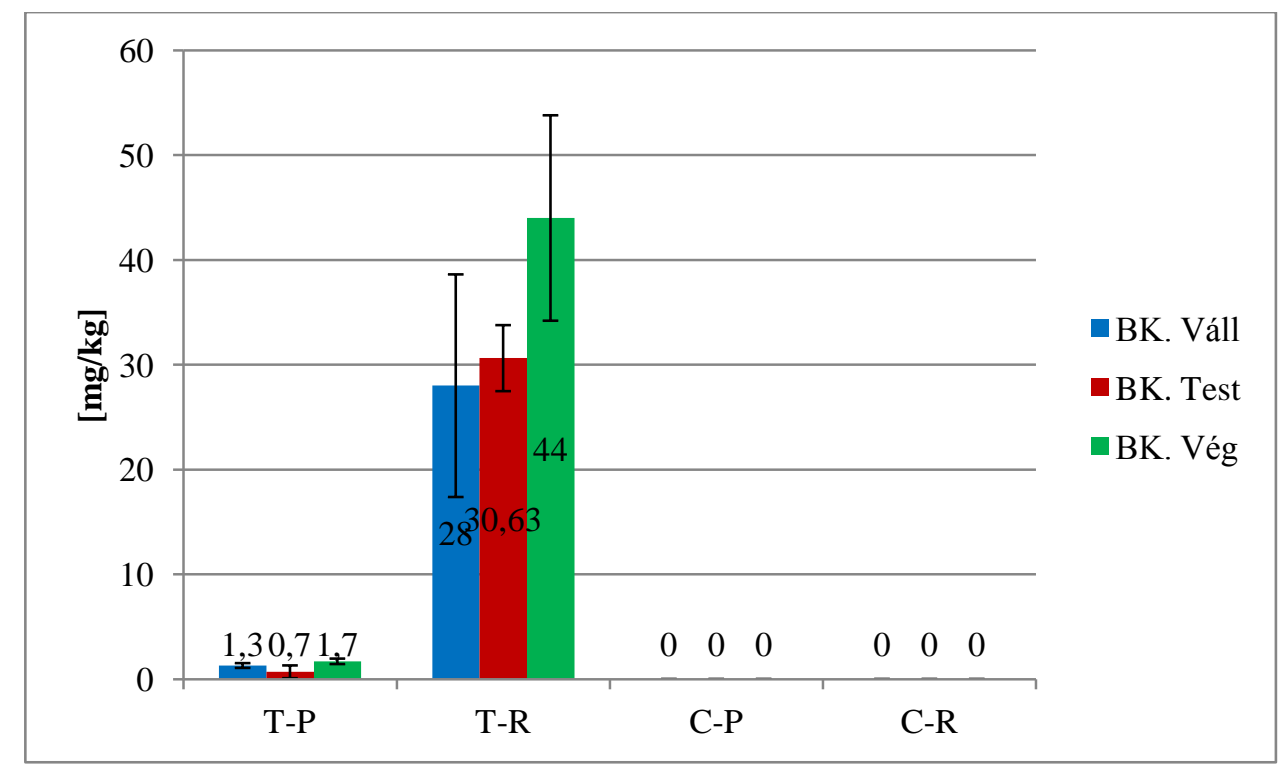

36. ábra: Rezveratrol vegyületek eloszlása a Bíbor kadarka szőlőfajta fürtjén belül a 2009-es évjáratban

A Bíbor kadarka kromatográfiás vizsgálatai során a transz-formákat sikerült detektálni a szőlőhéj kivonatokban. A transz-piceidet igen alacsony koncentrációban tudtam detektálni, a legmagasabb értéket a vállban mutattam ki. A transz rezveratrol már nagyobb mennyiségben 
fordul elő ebben a fajtában a 2009-es évjáratban, ami a fürt vég részében volt legnagyobb koncentrációban.

A 2009-es évjárat harmadik fajtáját, a Syrah szőlőhéjkivonatának fenolos vegyületeit a 37. és 38. ábra szemlélteti.

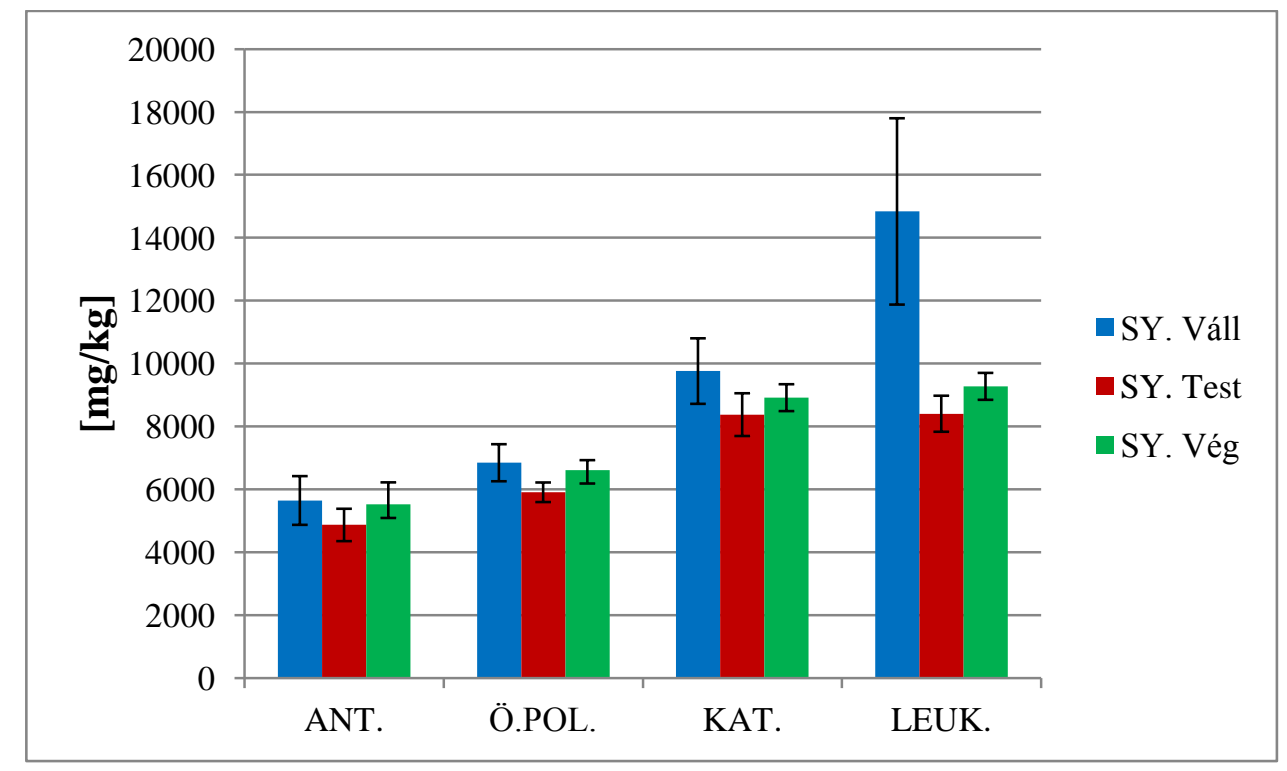

37. ábra: Syrah szőlőfajta fenolos vegyületeinek eloszlása a fürtön belül a 2009-es évjáratban

A Syrah szőlőfajta a borvidéken még nem rendelkezik hosszú múlttal, ezért is tartottam fontosnak, hogy ennek a szőlőfajtának is feltérképezzem a fenolos vegyületeit és megnézzem, hogy hol és milyen mennyiségben találhatóak ezek a vegyületek a fürtrészen belül.

Az antocianin-koncentráció a váll részben [5644 mg/kg héj] volt a legnagyobb mennyiségben, míg a legalacsonyabb értéket [4866 mg/kg héj] a középső rész adta. A váll és a vég részek között nagyon minimális eltérés figyelhető meg.

Az összespolifenol-tartalom szintén a váll részben [6845 mg/kg héj] a legmagasabb, míg a legalacsonyabb koncentrációt [5905 mg/kg héj] a középső részen mérten. Ennél a minőségi paraméternél is nagyon csekély különbség volt a váll és a vég részek között.

Magasabb koncentrációt mértem a többi világfajtához képest a katechintartalom tekintetében. A legmagasabb értéket a fürt váll részében [9760 mg/kg héj], míg a legalacsonyabb értéket a középső részben [8375 mg/kg héj] mértem.

A Syrah bogyóhéjminták leukoantocianin-tartalma $8403 \mathrm{mg} / \mathrm{kg}$ héj és $14838 \mathrm{mg} / \mathrm{kg}$ koncentrációk között mozogtak. Ez a minőségi paraméter a legnagyobb mennyiségben a vállban 
lokalizálódott, a legalacsonyabb értéket pedig a test részben mértem. Jelentős eltérés van mennyiségbeli szempontból a váll és a test szegmensek között.

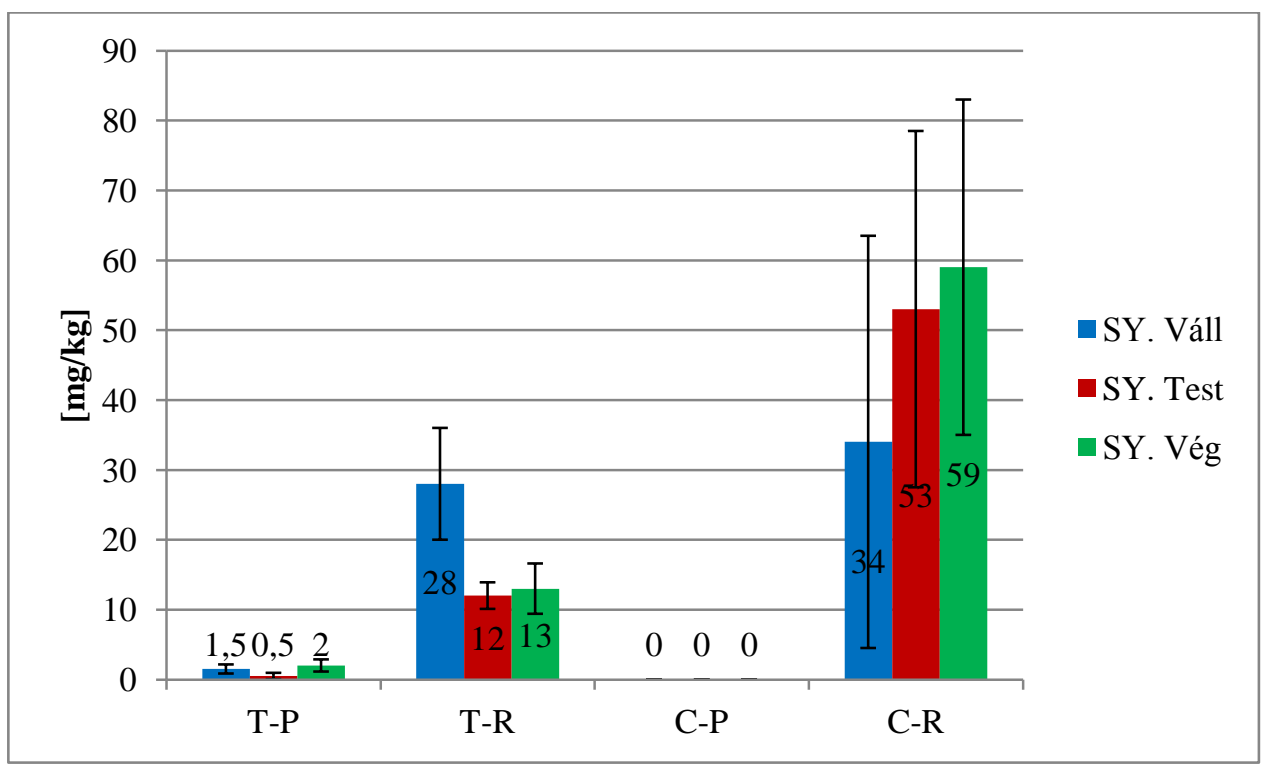

38. ábra: Syrah szőlőfajta rezveratrol tartalmának eloszlása a fürtön belül a 2009-es évjáratban

A Syrah extraktumok kromatográfiás vizsgálatával transz-piceidet, transz-rezveratrolt és ciszrezveratrolt tudtam kimutatni. A transz-rezveratrol megjelenését a savas hidrolízis reakciója, mely a glükozidos kötés felbomlását okozza, eredményezi a bogyóhéj mintákban. A legmagasabb értékeket a váll részben detektáltam, míg a transz-piceid és a cisz-rezveratrol koncentrációknál pedig a vég részekben voltak a legmagasabbak.

A 2009-es évjárat kiemelkedőnek mondható. A klimatikus viszonyoknak köszönhetően magas minőségű termést lehetett szüretelni. Ebben az évjáratban mind a három szőlőfajtánál a fenolos vegyületek a fürt felső részében, azaz a vállban akkumulálódtak. A terméskorlátozási módszerek közül a fürttépést és fürtfelezést lehet javasolni az ez évi tapasztalok alapján. A fajták között az élettanilag aktív vegyületek minőségbeli szempontból eltérést mutattak, amit a statisztika igazolt. A legmagasabb fenolos koncentrációkat a Bíbor kadarka szőlőfajta hozta ebben az évjáratban. A MANOVA teszt alapján van szignifikáns eltérés a fajták között (Wilks $\lambda=0,06, p<0,001$ ), tehát más mennyiségben és minőségben vannak jelen a fenolos vegyületek a szőlőhéj extraktumokban. A 2009-es évjáratban a különbségek ellenére a fürtrészeken belüli eloszlások között nincs szignifikáns differencia (Wilks $\lambda=0,88, \mathrm{p}=0,9$ ) egyik fajtánál sem (TU, BK, SY) az élettanilag aktív vegyületek szempontjából, ugyanis a normalitás sérült a kiugró értékek miatt, a szórások pedig magasak voltak. 


\subsection{Mustban mért összetevők}

A mustokban mért rutinanalitikai adatokat évjáratok szerint a 6., 7. és 8. táblázat szemlélteti. A mért paramétereket statisztikai módszerrel nem értékeltük ki. A mérések célja tájékoztatás volt a további borkezelési eljárások végett.

\subsubsection{7-es évjárat rutinanalitikai adatai}

A 2007-es évjáratban tíz szőlőfajtát vizsgáltam, melyekből alapborokat és házasítást készítettem.

A szüret teljes érettség állapotában történt, a fajták érési sorrendjéből adódóan szeptember elejétől október közepéig tartott.

6. táblázat: Mustok rutinanalitikai eredményei a 2007-es évjáratban

\begin{tabular}{l|c|c|c}
\hline 2007 & $\begin{array}{c}\text { REDUKÁLÓ CUKORTARTALOM } \\
{[\mathrm{g} / \mathrm{L}]}\end{array}$ & $\begin{array}{c}\text { TITRÁLHATÓ SAVTARTALOM } \\
{[\mathrm{g} / \mathrm{L}]}\end{array}$ & $\mathrm{pH}$ \\
\hline KM & 240 & 5,4 & 3,04 \\
\hline BLAU & 210 & 5,4 & 3,08 \\
\hline KO & 196 & 4,8 & 3,33 \\
\hline PN & 223 & 8,1 & 3,29 \\
\hline ZW & 192 & 7 & 2,84 \\
\hline KAD & 190 & 6,4 & 3,14 \\
\hline CF & 236 & 6,5 & 3,11 \\
\hline CS & 239 & 7,5 & 2,93 \\
\hline ME & 250 & 5,6 & 3,45 \\
\hline KF & 250 & 8,2 & 3,02 \\
\hline
\end{tabular}

A 2007-es évjáratból származó mustok redukáló cukortartalma átlagosnak bizonyult, ami az évjárat klimatikus helyzetének köszönhető. A legmagasabb cukortartalmat a Kékfrankos és Merlot fajtákban mértem: $250 \mathrm{~g} / \mathrm{L}$, ami körülbelül 22,5 ${ }^{\circ} \mathrm{MM}$-nak felel meg, amiből a várható alkoholtartalom több mint $14 \mathrm{~V} / \mathrm{V} \%$. A legalacsonyabb cukortartalommal a Zweigelt fajta bírt, 192 g/L, ami 18 MM-nak felel meg, a várható alkoholtartalom pedig körülbelül 12 V/V\%. 2007 nem számított egy kiemelkedő évjáratnak, de így is megfelelő minőséget adtak a szőlőfajták.

A mustok titrálható savtartalma 4,8 és $8,2 \mathrm{~g} / \mathrm{L}$ között változott a tíz szőlőfajtában. A kékszőlők optimális szintjéhez képest igen magas titrálható savtartalommal rendelkeznek a mustok. A legalacsonyabb koncentrációt a Kékoportóban, a legmagasabbat pedig a Kékfrankosban mértem.

A szüret optimális időpontjának megállapításához a cukor- és savtartalmon kívül a pH-értéket is figyelembe kell venni. A 2007-es évjáratban a pH értékek 2,84 és 3,45 között változtak. 


\subsubsection{8-as évjárat rutinanalitikai adatai}

A szüret teljes érettség állapotában történt, a fajták érési sorrendjéből adódóan szeptember elejétől október közepéig tartott.

7. táblázat: Mustok rutinanalitikai eredményei a 2008-as évjáratban

\begin{tabular}{l|c|c|c}
\hline 2008 & $\begin{array}{c}\text { REDUKÁLÓ CUKORTARTALOM } \\
{[\mathrm{g} / \mathrm{L}]}\end{array}$ & $\begin{array}{c}\text { TITRÁLHATÓ SAVTARTALOM } \\
{[\mathrm{g} / \mathrm{L}]}\end{array}$ & $\mathrm{pH}$ \\
\hline KM & 220 & 6 & 3,2 \\
\hline BLAU & 208 & 5,5 & 3,3 \\
\hline KO & 190 & 5,3 & 3,39 \\
\hline PN & 235 & 8 & 3,18 \\
\hline ZW & 200 & 6,5 & 3,25 \\
\hline KAD & 200 & 6,4 & 3,2 \\
\hline CF & 225 & 6,6 & 3,3 \\
\hline CS & 240 & 7,6 & 3,12 \\
\hline ME & 249 & 6,2 & 3,2 \\
\hline KF & 255 & 7 & 3,22 \\
\hline
\end{tabular}

A 2008-as évjáratban a legmagasabb redukáló cukortartalmat a Kékfrankos szőlőfajtánál mértem: $255 \mathrm{~g} / \mathrm{L}$, ami körülbelül $23^{\circ} \mathrm{MM}$-nak felel meg, a várható alkoholtartalom pedig körülbelül 15 V/V\%. A legalacsonyabb cukortartalommal a Kékoportó szőlőfajta bírt: 190 g/L, $18{ }^{\circ} \mathrm{MM}$, várható alkoholtartalom körülbelül: 11,3 V/V\%.

A mustok titrálható savtartalma a 2008-ban az előző évjárathoz képest alacsonyabb volt. A legmagasabb titrálható savtartalmat a Cabernet Sauvignon szőlőfajtánál mértem (7,6 g/L), míg a legalacsonyabbat a Kékoportónál (5,3 g/L).

2008-ban a pH-értékek egyenes arányban voltak a titrálható savtartalom értékeivel. A legalacsonyabb pH-t a Cabernet Sauvignon fajtánál mértem $(3,12)$, melynek sava pedig 7,6 g/L. A legmagasabb pH-értékkel a Kékoportó rendelkezett (3,39), melynek sava 5,3 g/L.

\subsubsection{9-es évjárat rutinanalitikai adatai}

A 2009-es évjáratban a tíz szőlőfajtán kívül még további három fajtát vizsgáltam, melyekből alapborokat és házasítást készítettem. A házasítás során a meglevő változaton kívül egy újabb verziót készítettem, melyben már tizenhárom szőlőfajta szerepel. A szüret teljes érettség állapotában történt, a fajták érési sorrendjéből adódóan augusztus végétől október elejéig tartott.

8. táblázat: Mustok rutinanalitikai eredményei a 2009-es évjáratban 


\begin{tabular}{l|c|c|c}
\hline 2009 & $\begin{array}{c}\text { REDUKÁLÓ CUKORTARTALOM } \\
{[\mathrm{g} / \mathrm{L}]}\end{array}$ & $\begin{array}{c}\text { TITRÁLHATÓ SAVTARTALOM } \\
{[\mathrm{g} / \mathrm{L}]}\end{array}$ & $\mathrm{pH}$ \\
\hline KM & 216 & 6,9 & 3,31 \\
\hline BLAU & 219 & 5,7 & 3,35 \\
\hline KO & 210 & 5,5 & 3,3 \\
\hline PN & 256 & 8,6 & 3,25 \\
\hline ZW & 212 & 6 & 3,32 \\
\hline KAD & 237 & 7 & 3,36 \\
\hline CF & 283 & 6,8 & 3,42 \\
\hline CS & 304 & 9,3 & 3,14 \\
\hline ME & 258 & 7,3 & 3,4 \\
\hline KF & 300 & 6,6 & 3,42 \\
\hline TU & 210 & 4,9 & 3,38 \\
\hline BK & 240 & 6,7 & 3,33 \\
\hline SY & 262 & 6,9 & 3,55 \\
\hline
\end{tabular}

A 2009-es évjáratban a mustok redukáló cukortartalma igen magas értéket mutatott, ami a kiemelkedő évjárathatásnak köszönhető. A legmagasabb cukortartalmat a Cabernet Sauvignon szőlőfajtánál mértem: $304 \mathrm{~g} / \mathrm{L}$, ami körülbelül 26,5 ${ }^{\circ} \mathrm{MM}-\mathrm{nak}$ felel meg, a várható alkoholtartalom pedig $17 \mathrm{~V} / \mathrm{V} \%$. A legalacsonyabb redukáló cukortartalommal a Kékoportó és a Turán szőlőfajták rendelkeztek: $210 \mathrm{~g} / \mathrm{L}$, ami körülbelül 19,5 ${ }^{\circ} \mathrm{MM}$-nak felel meg, a várható alkoholtartalom pedig 12,5 V/V\%.

A titrálható savtartalom és a pH-érték szoros kapcsolatban áll. A 2009-es évjáratban a titrálható savtartalom 4,9 és 8,6 g/L értékek között mozgott. A pH-értékek 3,14 és 3,55 között változtak.

\subsection{Borok alapanalitikai összetevői}

A borok alapanalitikai értékeit a 9., 10. és 11. táblázat foglalja össze. A borok le lettek mérve újbor állapotban, illetve egy évre rá, érlelt, azaz óbor állapotban. 


\subsubsection{A 2007-es évjárat borainak rutinanalitikai eredményei}

9. táblázat: 2007-es évjárat borainak alapanalitikai összetétele

\begin{tabular}{|c|c|c|c|c|}
\hline 2007 & $\begin{array}{l}\text { TITRÁLHATÓ SAV } \\
{[\mathrm{g} / \mathrm{L}]}\end{array}$ & $\mathrm{pH}$ & $\begin{array}{c}\text { ALKOHOL } \\
{[\mathrm{V} / \mathrm{V} \%]} \\
\end{array}$ & $\begin{array}{l}\text { C.M. EXTRAKT } \\
{[\mathrm{g} / \mathrm{L}]} \\
\end{array}$ \\
\hline KM ÚJ & 6,94 & 3,04 & 15,2 & 27,6 \\
\hline KM Ó & 5,5 & 3 & 13,77 & 24,76 \\
\hline BLAU ÚJ & 6,29 & 3,08 & 12,08 & 24,2 \\
\hline BLAU Ó & 4,4 & 3,2 & 11 & 21,38 \\
\hline KO ÚJ & 5,27 & 3,08 & 12,08 & 24,8 \\
\hline KO Ó & 5,8 & 3,2 & 10,55 & 22,42 \\
\hline PN ÚJ & 7,12 & 3,34 & 14,84 & 26,8 \\
\hline PN Ó & 4,8 & 3,3 & 13,67 & 24,76 \\
\hline ZW ÚJ & 6,85 & 3,29 & 12,08 & 23,5 \\
\hline ZW Ó & 5,1 & 3,31 & 11,19 & 21,9 \\
\hline KAD ÚJ & 7,03 & 2,84 & 13,74 & 34,4 \\
\hline KAD Ó & 7,9 & 3 & 12,32 & 33,34 \\
\hline CF ÚJ & 5,09 & 3,14 & 14,92 & 26,8 \\
\hline CF Ó & 4,3 & 3,1 & 14,11 & 23,2 \\
\hline CS ÚJ & 6,38 & 3,11 & 15,01 & 32 \\
\hline CS Ó & 4,7 & 3,2 & 14,35 & 24,76 \\
\hline ME ÚJ & 5,09 & 2,93 & 15,93 & 26,6 \\
\hline ME Ó & 4 & 3,2 & 14,97 & 24,76 \\
\hline KF ÚJ & 5,27 & 3,45 & 14,65 & 29,4 \\
\hline KF Ó & 4,3 & 3,4 & 13,52 & 27,1 \\
\hline BIKA ÚJ & 5,74 & 3,02 & 14,2 & 26,6 \\
\hline BIKA Ó & 6 & 3,1 & 12,87 & 25,02 \\
\hline
\end{tabular}

A borok titrálható savtartalmának értékei az érlelés hatására csökkenő tendenciát mutatnak, egykét fajtánál figyelhető meg stagnálás. A savértékek a 2007-es évjáratban átlagosnak mondhatóak, nincsenek kiugró értékek. Az alkoholtartalom az érlelés hatására a várakozásoknak megfelelően alakult, minden esetben alacsonyabb értékeket mértem az ó borokban. A borok cukormentes extrakttartalma az új borokban 23,5 és 34,4 g/L értékek között mozgott. Az óborokban 21,28 és 33,34 g/L koncentrációk között változott. Ennél a paraméternél is csökkenés figyelhető meg az óborokban. 


\subsubsection{8-as évjárat borainak rutinanalitikai eredményei}

10. táblázat: 2008-as évjárat borainak alapanalitikai összetétele

\begin{tabular}{l|c|c|c|c}
\hline \multicolumn{1}{c|}{2008} & $\begin{array}{c}\text { TITRÁLHATÓ SAV } \\
{[\mathrm{g} / \mathrm{L}]}\end{array}$ & $\mathrm{pH}$ & $\begin{array}{c}\text { ALKOHOL } \\
{[\mathrm{V} / \mathrm{V} \%]}\end{array}$ & $\begin{array}{c}\text { C.M. EXTRAKT } \\
{[\mathrm{g} / \mathrm{L}]}\end{array}$ \\
\hline KM ÚJ & 4,4 & 3,2 & 14,7 & 28,66 \\
\hline KM Ó & 3,9 & 3 & 14,45 & 25,04 \\
\hline BLAU ÚJ & 7,5 & 3,2 & 16,82 & 43,64 \\
\hline BLAU Ó & 7,1 & 3,15 & 16,28 & 37,08 \\
\hline KO ÚJ & 5,4 & 3,1 & 11,38 & 22,42 \\
\hline KO Ó & 4,6 & 3,24 & 11,54 & 20,42 \\
\hline PN ÚJ & 5,1 & 3,32 & 14,49 & 25,28 \\
\hline PN Ó & 4,3 & 3,3 & 14,35 & 21,54 \\
\hline ZW ÚJ & 5,6 & 3,1 & 12,32 & 26,06 \\
\hline ZW Ó & 4,9 & 3,1 & 12,25 & 23,02 \\
\hline KAD ÚJ & 7,8 & 2,9 & 16,19 & 41,82 \\
\hline KAD Ó & 7,3 & 3,21 & 15,15 & 36,12 \\
\hline CF ÚJ & 6,2 & 3,3 & 13,3 & 23,2 \\
\hline CF Ó & 5,4 & 3,2 & 13,69 & 23,52 \\
\hline CS ÚJ & 6,7 & 3 & 13,39 & 25,02 \\
\hline CS Ó & 5,1 & 3,1 & 13,52 & 22,5 \\
\hline ME ÚJ & 5,3 & 3,3 & 12,44 & 22,42 \\
\hline ME Ó & 4,7 & 3,3 & 12,59 & 20,68 \\
\hline KF ÚJ & 7,4 & 3,2 & 12,78 & 29,96 \\
\hline KF Ó & 4,8 & 3,12 & 12,6 & 23,74 \\
\hline BIKA ÚJ & 6 & 3,3 & 13,6 & 29,44 \\
\hline BIKA Ó & 5,2 & 3,2 & 13,45 & 24,9 \\
\hline
\end{tabular}

A 2008-as évjáratban a titrálható savtartalom értékei alacsonyabbak a 2007-es évjárathoz képest. Ebben az évben mért savkoncentrációk jobban tükrözik a vörösborokra jellemző értékeket. Egykét fajtánál jellemző kiugró érték, mint például a Blauburgernél [új: 7,5 g/L; ó: 7,1 g/L] és a Kadarkánál [új: 7,8 g/L; ó: 7,3 g/L]. Ebben az évjáratban is csökkenő tendencia mutatkozik meg a savtartalom tekintetében az érlelés hatására. Az alkoholtartalom szempontjából kiugróan magas értéket a Blauburger fajtánál mértem: új: 16,83 V/V\%; ó: 16,28 V/V\%. A must cukortartalmát alkoholra átszámítva alacsonyabb értékek alakultak ki. A 2008-as évjárat extrakttartalma ismételten csökkenő tendenciát mutat az óborokban. Az összes bor közül kiemelkedő extrakttartalommal a Blauburger szőlőfajta bírt.

\subsubsection{9-es évjárat borainak rutinanalitikai eredményei}

A 2009-es évjárattól kezdődően még további három szőlőfajtával dolgoztam. Az alapanalitikai eredmények között ez a három szőlőfajta tájékoztató jelleggel szerepel a táblázatban, viszont a 
későbbiekben a statisztikai kiértékelés miatt nem, de a mellékletben a fajták fenolos vegyületeinek adatai és érzékszervi bírálati eredményei megtalálhatóak.

11. táblázat: 2009-es évjárat borainak alapanalitikai összetétele

\begin{tabular}{|c|c|c|c|c|}
\hline 2009 & $\begin{array}{l}\text { TITRÁLHATÓ SAV } \\
{[\mathrm{g} / \mathrm{L}]}\end{array}$ & $\mathrm{pH}$ & $\begin{array}{l}\text { ALKOHOL } \\
\text { [V/V\%] }\end{array}$ & $\begin{array}{l}\text { C.M. EXTRAKT } \\
{[\mathrm{g} / \mathrm{L}]}\end{array}$ \\
\hline KM ÚJ & 5 & 3,31 & 12,7 & 25,34 \\
\hline KM Ó & 4,8 & 3,3 & 12,77 & 23,24 \\
\hline BLAU ÚJ & 5,3 & 3,35 & 13,43 & 27,4 \\
\hline BLAU Ó & 5,8 & 3,24 & 12,92 & 22,52 \\
\hline KO ÚJ & 5 & 3,2 & 12,11 & 25,12 \\
\hline KO Ó & 5,5 & 3,1 & 11,89 & 23,96 \\
\hline PN ÚJ & 4,1 & 3,25 & 14,78 & 25,26 \\
\hline PN Ó & 4,5 & 3,12 & 15,43 & 23,54 \\
\hline ZW ÚJ & 5 & 3,32 & 12,87 & 23,28 \\
\hline ZW Ó & 4,9 & 3,2 & 12,71 & 20,4 \\
\hline KAD ÚJ & 5,9 & 3,36 & 14,27 & 26,58 \\
\hline KAD Ó & 5,4 & 3,23 & 14,13 & 25,76 \\
\hline CF ÚJ & 5,2 & 3,42 & 16,05 & 24,68 \\
\hline CF Ó & 4,5 & 3,34 & 16,36 & 22,2 \\
\hline CS ÚJ & 5,1 & 3,14 & 15 & 25,98 \\
\hline CS Ó & 4,9 & 3,21 & 15,25 & 23,28 \\
\hline ME ÚJ & 6,1 & 3,4 & 14,71 & 22,72 \\
\hline ME Ó & 5,6 & 3,3 & 14,72 & 21,36 \\
\hline KF ÚJ & 5,6 & 3,23 & 13,74 & 22,54 \\
\hline KF Ó & 4,9 & 3,33 & 13,96 & 20,12 \\
\hline TU ÚJ & 4,6 & 3,38 & 12,82 & 25,98 \\
\hline TU Ó & 5,7 & 3,4 & 13,17 & 29,18 \\
\hline BK ÚJ & 6 & 3,33 & 12,83 & 26,74 \\
\hline BK Ó & 6,4 & 3,2 & 12,63 & 24,78 \\
\hline SY ÚJ & 4,9 & 3,2 & 15,38 & 25,58 \\
\hline SY Ó & 5,1 & 3,4 & 15,22 & 25,56 \\
\hline BIKA ÚJ & 5,3 & 3,3 & 14,08 & 24,08 \\
\hline BIKA Ó & 5,5 & 3,2 & 13,75 & 20,46 \\
\hline
\end{tabular}

A 2009-es évjárat kiemelkedő klimatikus adottságokkal rendelkezett. A titrálható savtartalom szempontjából a három évjárat közül ebben az évben voltak a legszebb savak, melyek a borokban nem durvák, harmonikusak. 2009-ben is az érlelés hatására minimális sav csökkenés figyelhető meg a borokban. A must magas redukáló cukortartalmának ellenére a borok 
alkoholtartalma fajtára jellemző értékeket adott. Magasabb alkoholt ebben az évben a Cabernet franc szőlőfajtánál mértem. A borok extrakt értékeinél kiugró adatok nem szerepelnek.

\subsection{Borok fenolos komponenseinek vizsgálati értékei}

A borok vizsgálatát mind a három évjáratban $(2007,2008,2009)$ statisztikailag az ANOVA és a MANOVA módszerével érékeltem ki. Kutatási munkám során az érlelés és házasítás hatását vizsgáltam a borok fenolos összetételére. A többváltozós ANOVA eredményei szignifikánsak az évre [Wilk $\lambda=0,17, \mathrm{p}<0,001$ ], a fajtára [Wilk $\lambda=0,19, \mathrm{p}<0,001$ ] és az érlelésre [Wilk $\lambda=0,585$, $\mathrm{p}<0,001]$ is. A borokban vizsgált fenolos összetevők mérési eredményeit a 12., 13. és 14. táblázat foglalja össze.

12. táblázat: A 2007-es évjáratból származó borok fenolos összetevőinek vizsgálati értékei

\begin{tabular}{l|c|c|c|c|c|c}
\hline \multicolumn{1}{c|}{2007} & ANT. $[\mathrm{mg} / \mathrm{L}]$ & Ö.POL. $[\mathrm{mg} / \mathrm{L}]$ & KAT.[mg/L] & LEUK.[mg/L] & SZI. & SZÁ. \\
\hline KM ÚJ & 264 & 1295 & 863,5 & 1683,9 & 4,2 & 0,58 \\
\hline KM Ó & 218,46 & 1464,7 & 736,39 & 815,92 & 5,2 & 0,67 \\
\hline BLAU ÚJ & 377,2 & 1423,8 & 249,5 & 711,7 & 7,3 & 0,47 \\
\hline BLAU Ó & 399,8 & 1795,2 & 256,125 & 781,2 & 4,35 & 0,67 \\
\hline KO ÚJ & 226,5 & 758,1 & 223,2 & 659,6 & 2,5 & 0,79 \\
\hline KO Ó & 196,37 & 1001,2 & 376,71 & 685,72 & 3,73 & 0,76 \\
\hline PN ÚJ & 123,7 & 1531,5 & 1515,25 & 1788 & 2,7 & 0,83 \\
\hline PN Ó & 126,6 & 1608,9 & 1185,95 & 1215,2 & 2,65 & 1,05 \\
\hline ZW ÚJ & 239,2 & 1144,6 & 740,7 & 1510,3 & 5,3 & 0,45 \\
\hline ZW Ó & 266,14 & 1464,7 & 609,19 & 1241,24 & 4,3 & 0,59 \\
\hline KAD ÚJ & 93 & 736,6 & 258,3 & 538,1 & 1,1 & 1,39 \\
\hline KAD Ó & 91,72 & 784,9 & 297,792 & 303,8 & 1,13 & 1,38 \\
\hline CF ÚJ & 180,75 & 1080,2 & 644,28 & 1320,88 & 3,71 & 0,8 \\
\hline CF Ó & 196,37 & 1104,2 & 530,25 & 963,48 & 3,79 & 0,89 \\
\hline CS ÚJ & 345,75 & 1681,6 & 810,95 & 2574,88 & 8,32 & 0,57 \\
\hline CS Ó & 337,07 & 1567,7 & 1148,67 & 2256,8 & 7,85 & 0,74 \\
\hline ME ÚJ & 153,75 & 1144,7 & 227,61 & 1045 & 3,95 & 1 \\
\hline ME Ó & 208 & 846,7 & 449,1 & 381,92 & 3,61 & 1,05 \\
\hline KF ÚJ & 251,25 & 758,1 & 190,33 & 635,36 & 4,51 & 0,72 \\
\hline KF Ó & 312,65 & 846,7 & 332,88 & 503,44 & 398 & 0,85 \\
\hline BIKA ÚJ & 227,25 & 1026,6 & 530,25 & 1102,36 & 5,1 & 0,65 \\
\hline BIKA Ó & 266,14 & 1516,2 & 508,32 & 1085 & 4,92 & 0,76 \\
\hline
\end{tabular}


13. táblázat: A 2008-as évjáratból származó borok fenolos összetevőinek vizsgálati értékei

\begin{tabular}{l|c|c|c|c|c|c}
\hline \multicolumn{1}{c|}{2008} & ANT. $[\mathrm{mg} / \mathrm{L}]$ & Ö.POL. $[\mathrm{mg} / \mathrm{L}]$ & KAT.[mg/L] & LEUK.[mg/L] & SZI. & SZÁ. \\
\hline KM ÚJ & 295,21 & 1979,7 & 1703,5 & 2022,44 & 3,8 & 0,903 \\
\hline KM Ó & 266,1 & 2340,2 & 1343,9 & 2048,5 & 3,36 & 1,09 \\
\hline BLAU ÚJ & 510,33 & 1773,7 & 1302,18 & 772,52 & 7,6 & 0,853 \\
\hline BLAU Ó & 372 & 2020,9 & 1330,7 & 651 & 5,96 & 1,05 \\
\hline KO ÚJ & 269,63 & 1279,3 & 628,93 & 624,96 & 2,6 & 0,66 \\
\hline KO Ó & 225,4 & 1155,7 & 508,3 & 677,04 & 2,3 & 0,86 \\
\hline PN ÚJ & 155,67 & 1052,7 & 644,28 & 737,8 & 2,4 & 1,2 \\
\hline PN Ó & 154,5 & 1104,2 & 508,3 & 564,2 & 1,6 & 1,53 \\
\hline ZW ÚJ & 452,19 & 1516,2 & 870,16 & 390,6 & 4,1 & 0,731 \\
\hline ZW Ó & 327,8 & 1505,9 & 1001,7 & 642,3 & 3,7 & 0,89 \\
\hline KAD ÚJ & 180,09 & 1567,7 & 1082,88 & 1093,68 & 2,2 & 1,045 \\
\hline KAD Ó & 155,7 & 1670,7 & 892 & 868 & 2,2 & 1,36 \\
\hline CF ÚJ & 240,56 & 939,4 & 424,98 & 312,48 & 2,4 & 1,008 \\
\hline CF Ó & 195,2 & 898,2 & 477,6 & 520,8 & 1,9 & 1,21 \\
\hline CS ÚJ & 414,98 & 1773,7 & 1023,67 & 694,4 & 5,9 & 0,713 \\
\hline CS Ó & 335,9 & 1567,7 & 935,9 & 1258,6 & 4,35 & 0,89 \\
\hline ME ÚJ & 324,28 & 898,2 & 324,28 & 208,32 & 3,1 & 0,725 \\
\hline ME Ó & 237,1 & 949,7 & 237,1 & 607,6 & 2,5 & 0,85 \\
\hline KF ÚJ & 254,51 & 939,4 & 617,97 & 434 & 3,5 & 0,734 \\
\hline KF Ó & 173,12 & 1145,4 & 580,7 & 347,2 & 2,6 & 0,99 \\
\hline BIKA ÚJ & 301,02 & 1464,7 & 881,13 & 1345,4 & 3,5 & 0,807 \\
\hline BIKA Ó & 253,4 & 1773,7 & 756,1 & 824,6 & 2,7 & 1,2 \\
\hline
\end{tabular}


14. táblázat: A 2009-es évjáratból származó borok fenolos összetevőinek vizsgálati értékei

\begin{tabular}{l|c|c|c|c|c|c}
\hline \multicolumn{1}{c|}{2009} & ANT. $[\mathrm{mg} / \mathrm{L}]$ & Ö.POL. $[\mathrm{mg} / \mathrm{L}]$ & KAT.[mg/L] & LEUK.[mg/L] & SZI. & SZÁ. \\
\hline KM ÚJ & 301,02 & 1516,2 & 694,7 & 1328,04 & 4,8 & 0,86 \\
\hline KM Ó & 219,63 & 1602,3 & 782,44 & 1492,96 & 4,56 & 0,88 \\
\hline BLAU ÚJ & 801,03 & 1619,2 & 291,21 & 269,08 & 9,9 & 0,83 \\
\hline BLAU Ó & 511,49 & 1602,3 & 299,98 & 972,16 & 9,95 & 0,64 \\
\hline KO ÚJ & 568,5 & 1619,2 & 568,5 & 668,36 & 5,8 & 0,79 \\
\hline KO Ó & 360,33 & 2219,34 & 360,33 & 1197,84 & 6,41 & 0,81 \\
\hline PN ÚJ & 196,4 & 2134,2 & 1506,1 & 1102,36 & 4,1 & 1,1 \\
\hline PN Ó & 182,42 & 2239,24 & 1278,06 & 1996,4 & 3,33 & 1,17 \\
\hline ZW ÚJ & 452,2 & 1155,7 & 431,6 & 338,52 & 6,1 & 0,54 \\
\hline ZW Ó & 290,56 & 1373,4 & 903,06 & 876,68 & 4,43 & 0,69 \\
\hline KAD ÚJ & 213,8 & 795,2 & 240,7 & 381,92 & 3,3 & 0,88 \\
\hline KAD Ó & 178,93 & 1005,17 & 36,82 & 841,96 & 2,43 & 0,92 \\
\hline CF ÚJ & 545,2 & 1670,7 & 418,4 & 1206,52 & 9,45 & 0,87 \\
\hline CF Ó & 369,63 & 1801,34 & 508,32 & 1597,12 & 7,15 & 0,88 \\
\hline CS ÚJ & 870,8 & 2762,5 & 179,4 & 2716,84 & 15,25 & 0,52 \\
\hline CS Ó & 552,19 & 3244,41 & 924,99 & 3393,88 & 12,69 & 0,79 \\
\hline ME ÚJ & 481,3 & 1516,2 & 1591,6 & 564,2 & 8,27 & 0,65 \\
\hline ME Ó & 344,05 & 1433,11 & 392,09 & 1501,64 & 6,26 & 0,76 \\
\hline KF ÚJ & 376,6 & 1413,2 & 628,9 & 694,4 & 7,2 & 0,69 \\
\hline KF Ó & 253,35 & 1383,35 & 499,54 & 1319,36 & 5,85 & 0,72 \\
\hline TU ÚJ & 998,7 & 2906,7 & 1933,7 & 2239,44 & 18 & 0,57 \\
\hline TU Ó & 732,42 & 2975,7 & 1251,74 & 3072,72 & 12,64 & 0,72 \\
\hline BK ÚJ & 1176,6 & 2494,7 & 1451,3 & 2213,4 & 24,8 & 0,53 \\
\hline BK Ó & 812,66 & 2796,56 & 1034,64 & 2430,4 & 17,16 & 0,7 \\
\hline SY ÚJ & 673,1 & 1289,6 & 639,9 & 989,52 & 9,3 & 0,57 \\
\hline BY Ó & 504,51 & 1512,73 & 525,86 & 1310,68 & 6,43 & 0,76 \\
\hline BIKA Ó & 321,95 & 1642,11 & 407,44 & 1527,68 & 7,14 & 0,73 \\
\hline & & & & & & \\
\hline
\end{tabular}

\subsubsection{Antocianin-tartalom}

A kékszőlők és vörösborok színét az antocianinok határozzák meg. A héjban az epidermisz alatti 3-4 sejtsorban helyezkednek el. Mennyiségük és minőségük jelenléte a szőlőben és a borban több tényezőtől függ. A szőlőben zömében antocianin-monomer állapotban vannak jelen, melynek mennyisége az erjedés és az érés elörehaladtával csökken, és eltérő polimerizált termékek képződnek. Ezek fontos szerepet játszanak a vörösborok színének kialakításában. A borok antocianin-tartalmát három évjárat átlagában az új- és óborokban a 39. ábra szemlélteti. 


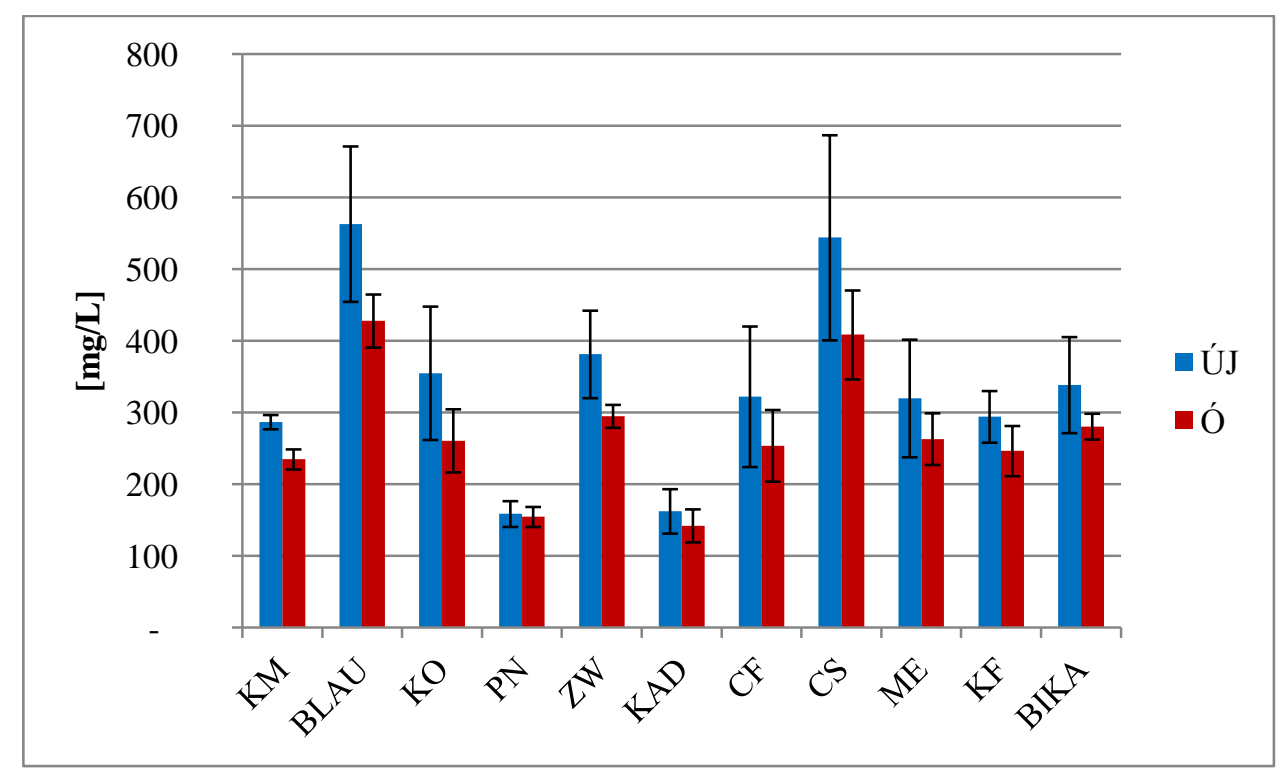

39. ábra: A borok antocianin-tartalma (3 évjárat átlaga)

A bor fejlődése és érése során az antocianin-monomerek különböző fizikai, kémiai és biokémiai folyamatokon mennek keresztül. Az érlelés hatására mindegyik alapborban, valamint a házasításban is a mennyiségük csökkent, ami valószínűleg a polikondenzációs folyamatoknak tudható be.

Az irodalmi adatok alapján mind a három évjáratban, mindegyik fajtánál a mért értékek magasabbak. Magasabb antocianin-értékekkel rendelkeznek a Blauburger, a Zweigelt és Cabernet Sauvignon szőlőfajták.

A három évjárat átlagos antocianin-értékei az újborokban 159 és $563 \mathrm{mg} / \mathrm{L}$ között mozogtak, míg az óborokban 142 és 428 mg/L koncentrációk voltak. Az érlelés hatására csökkent az antocianin-koncentráció az alapborokban és az Egri Bikavérben egyaránt. 


\subsection{2. Összespolifenol-tartalom}

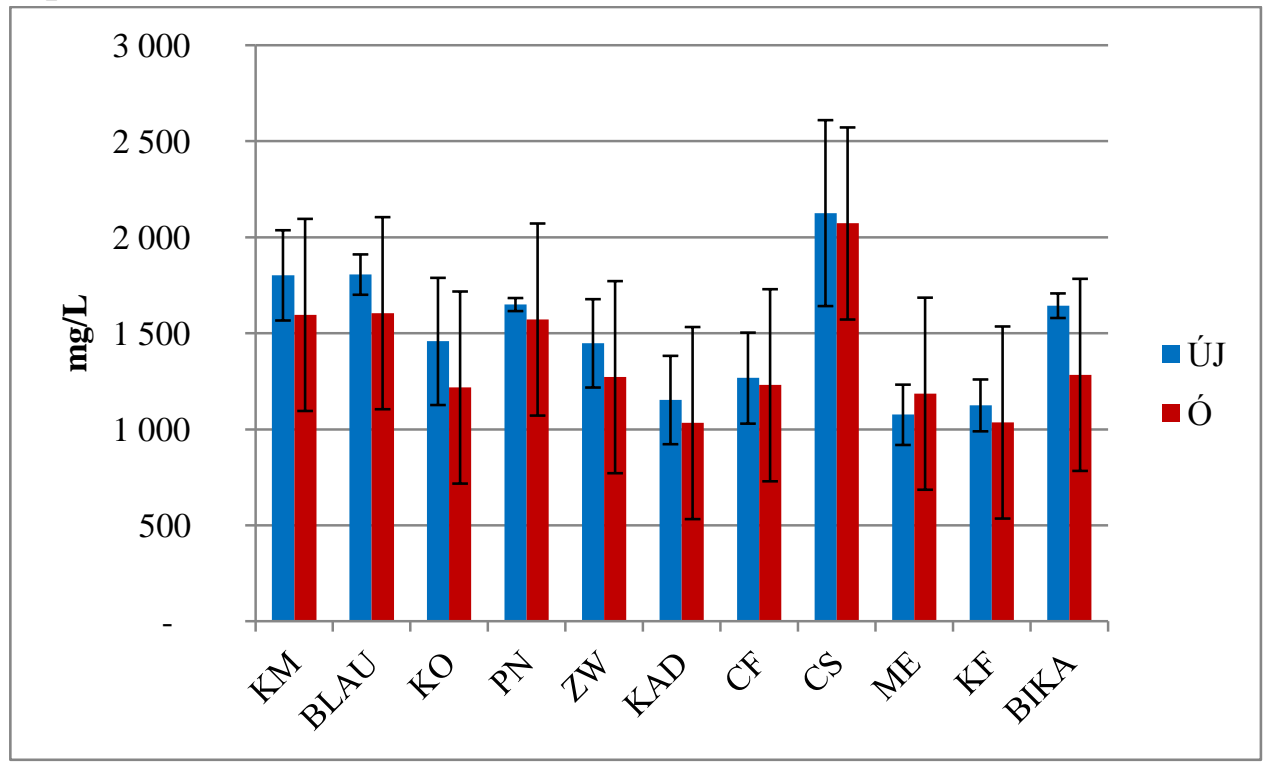

40. ábra: A borok összespolifenol-tartalma (3 év átlaga)

Az újborokban mért összespolifenol-tartalom 1076 mg/L (Merlot) és 2126 mg/L (Cabernet Sauvigon) értékek között mozgott három év átlaga alapján. A Bikavérben újbor állapotban 1644 mg/L koncentrációt mértem, mely érték pont a szélső értékek között áll.

Az alapborokban és a házasított Bikavérben is az összespolifenol-koncentráció a házasítás hatására csökkent, kivételt képez a Merlot fajta. Ennél a fajtánál minimális emelkedés figyelhető meg. A különbségek ellenére a statisztika szignifikáns differenciát nem mutatott ki.

Az óborokban mért összespolifenol-tartalom 1033 mg/L (Kadarka) és 2072 mg/L (Cabernet Sauvignon) határok között változott. A Bikavérben óbor állapotban $1284 \mathrm{mg} / \mathrm{l}$ értéket sikerült kimutatnom a három év átlaga alapján.

A borokban mért polifenol-koncentráció megegyezik az irodalmi adatokkal. A három évjáratot külön-külön figyelembe véve a 2009-es évben volt a boroknak a legmagasabb összespolifenoltartalma (12., 13., 14. táblázat). 


\subsubsection{Katechintartalom}

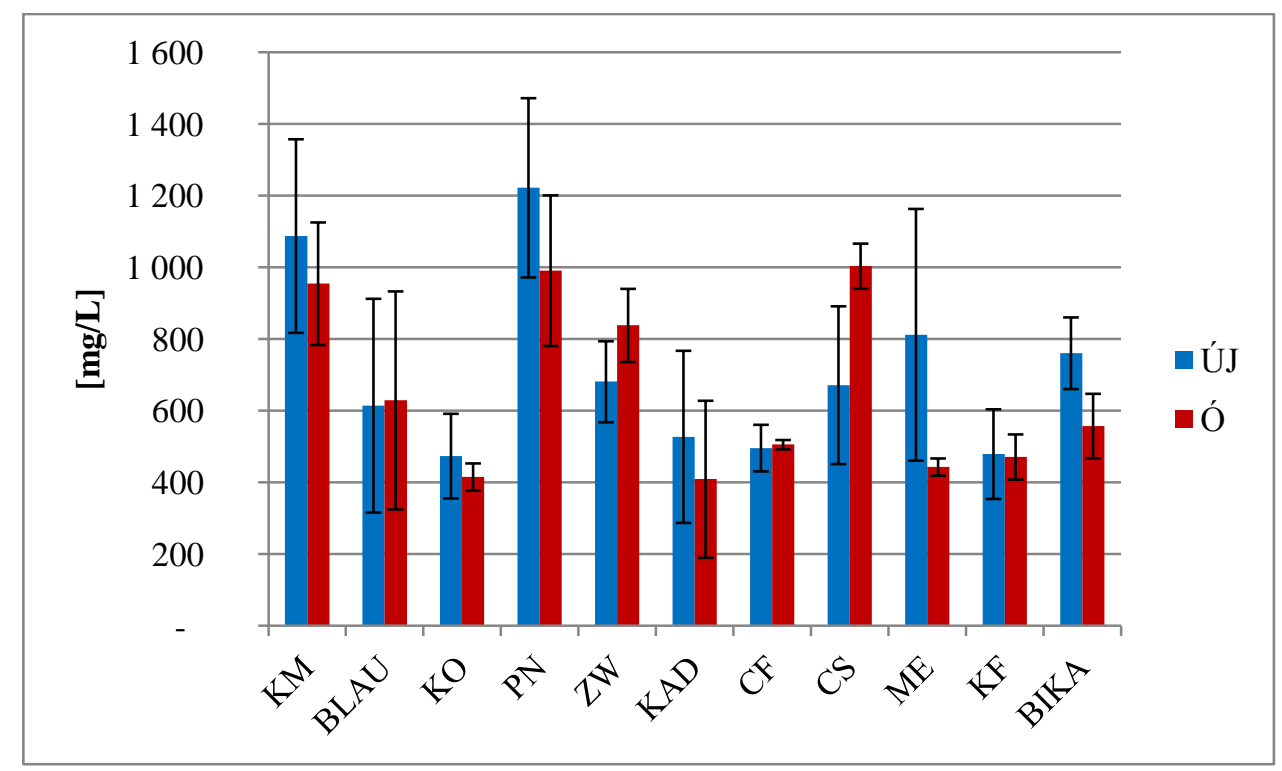

41. ábra: A borok katechintartalma (3 év átlaga)

A borok katechintartalma az érlelés hatására változatosan alakult, esetenként csökkenő, máskor növekvő tendenciát mutatott. A három év átlaga alapján a legmagasabb katechinkoncentrációt a Pinot noir szőlőfajtánál [1222 mg/L] mértem újbor állapotban. A legalacsonyabb értéket pedig a Kadarka $[409$ mg/L] mutatta óbor állapotban.

A különböző évjáratokban más és más koncentrációt mértem minden fajta esetében. Általánosságban megállapítható, hogy a 2008-as évjáratban a fajták többségében magasabb katechintartalommal rendelkeztek a borok a másik két évjárathoz képest.

A Bikavérben az érlelés hatására a katechintartalom csökkent, ami nagy valószínüséggel a polimerizációnak köszönhető, ugyanis a katechin-monomerek kondenzációs reakciók során különböző polimerizációs fokú és molekulasúlyú polimer tanninvegyületekké alakulnak. A katechinek a procianidinek prekurzorjai. A csökkenés a borok érzékszervi szempontjából előnyössé válhat, mint jelen esetben a Bikavérnél is. A katechin-monomerek a borban keserübb, húzósabb ízt okoznak, mint polimerizált származékaik, a kondenzált tanninok. Ezért is magyarázható az, hogy az érlelés hatására a borok finomodnak, keserü ízérzetűek csökken. 


\subsubsection{Leukoantocianin-tartalom}

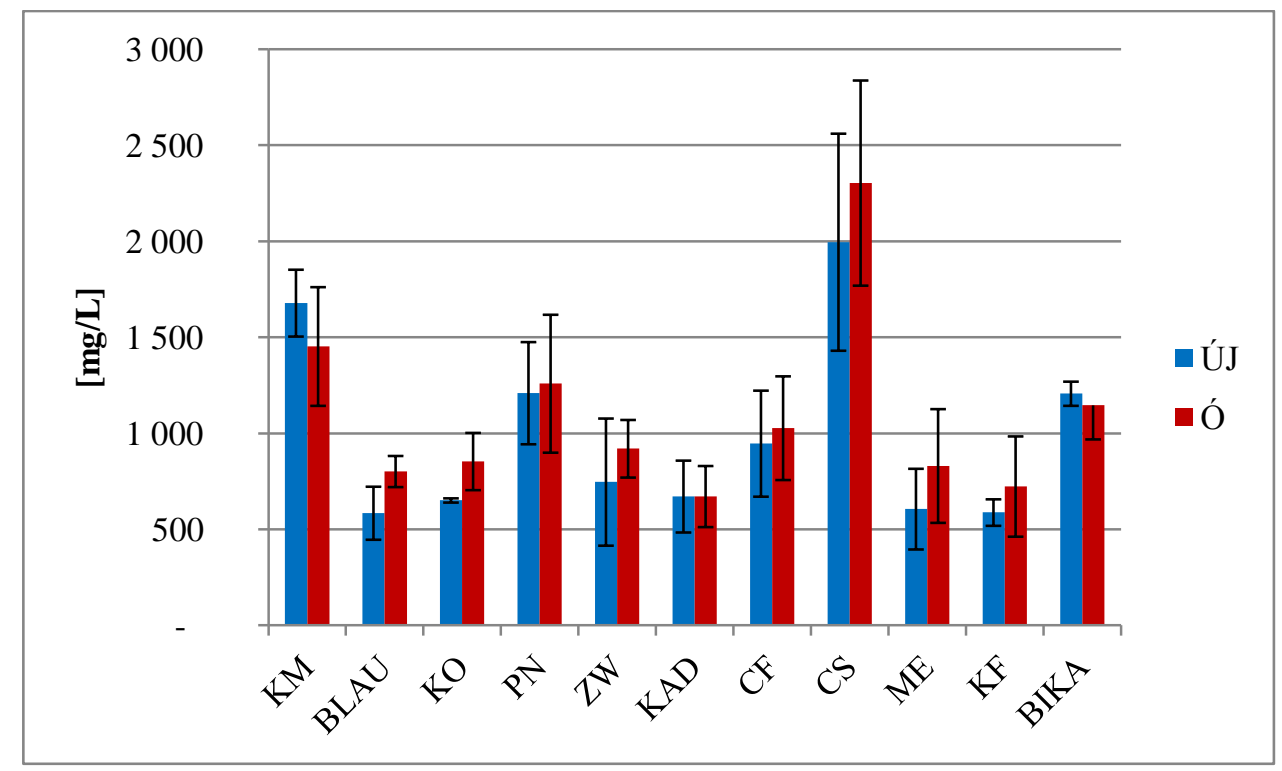

42. ábra: A borok leukoantocianin-tartalma (3 év átlaga)

Három év átlaga alapján a borok leukoantocianin-tartalma a katechinekhez hasonlóan hol csökkenő, hol növekvő trendet követett az érlelés hatására, ami az esetek többségében korrelációban van az érzékszervi bírálati eredményekkel.

A leukoantocianin a másik olyan vegyületcsoport a borban, mely jelentősen befolyásolja az érzékszervi tulajdonságokat. Az összehúzó ízük a polmerizációs fok függvénye. A kis kondenzációs fokú és molekulatömegü vegyületek összehúzó, fanyar íztulajdonságokkal rendelkeznek.

A három évjáratban közel hasonló értékeket mértem, egyes szőlőfajtáknál voltak eltérések. Három év átlaga alapján a legmagasabb értéket a Cabernet Sauvignon fajtában [2303 mg/L] mértem óbor állapotban, míg a legalacsonyabb értéket a Blauburger fajtában [584 mg/L].

A Bikavérben a katechinkoncentrációhoz hasonlóan az érlelés hatására a leukoantocianintartalom csökkent, amely a polimerizációnak köszönhető, vagy az oxidatív reakció hatására a $\mathrm{Fe}(\mathrm{II})$ átalakítja antocianinokká.

A leukonatocianin-tartalomnál a statisztika szignifikáns differenciát nem mutatott ki az ó- és újborok között.

\subsubsection{Színintenzitás és színárnyalat}

A vörösborokkal kapcsolatos legalapvetőbb fogyasztói elvárás az elegáns vörös szín. A borok színének két meghatározó vonása a színintenzitás és színerősség. Ezek a jellemzők az érés, 
érlelés során jelentősen változnak. A bor színéből következtetni lehet a fajtára, a borkészítési eljárásra, valamint a korára.

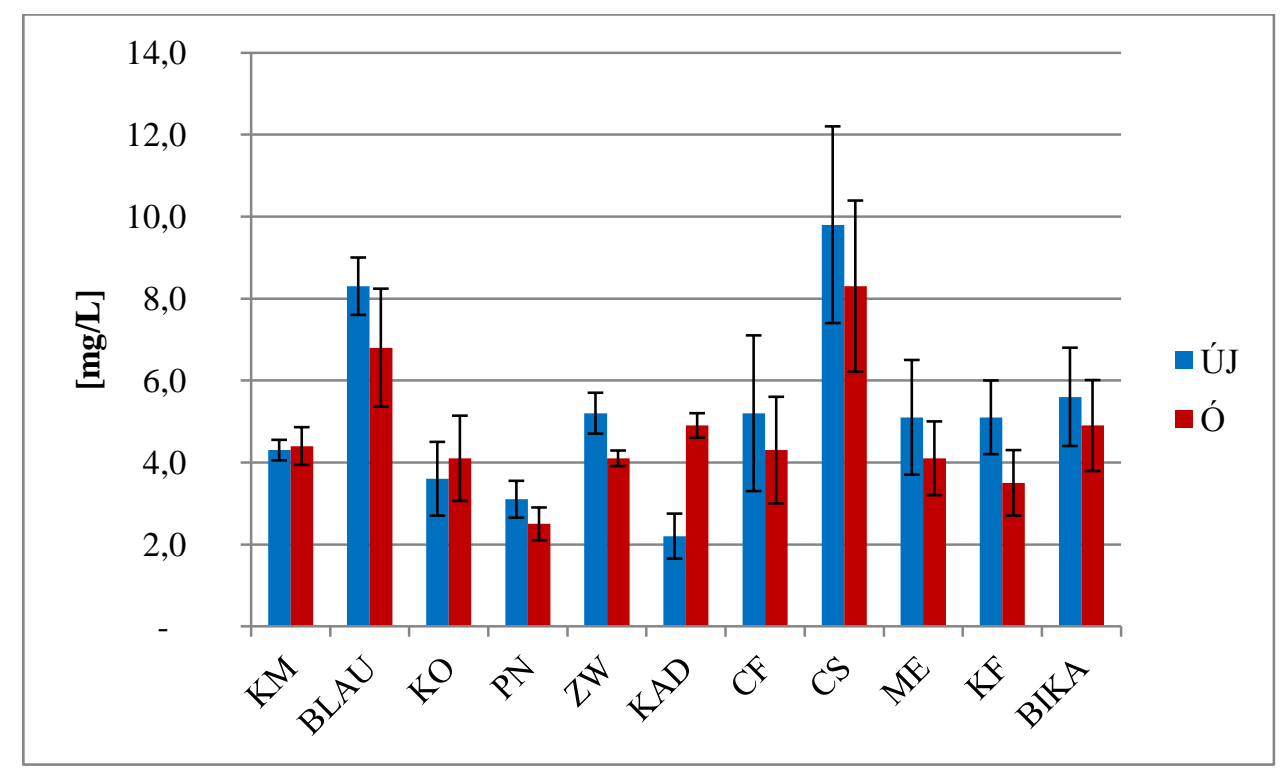

43. ábra: A borok színintenzitása (3 év átlaga)

A borok színintenzitása fajtánként jelentősen eltér. Újbor állapotban három év átlaga alapján a borok színintenzitása 2,2 és 9,8 között változott. A Kadarka szőlöfajtában mértem a legalacsonyabb értéket, a legmagasabbat pedig a Cabernet Sauvignon fajtában.

A Bikavér színintenzitása újborban 5,6, óborban 4,9. Ezek az eredmények pont a két szélsőérték között mozognak. A Bikavérre jellemzően nem szabad színben, illatban és ízben dominálnia egyik fajtának sem, így a Bikavér házasításánál az „arany középutat” kell megtalálni.

Az érlelés hatására színanyagkiválás nem minden fajtánál következett be. Az irodalmi adatok alapján az újborok színerőssége nagyobb értékkel bír az érlelt borokhoz képest.

A színintenzitás értékei között nincs szignifikáns különbség. 


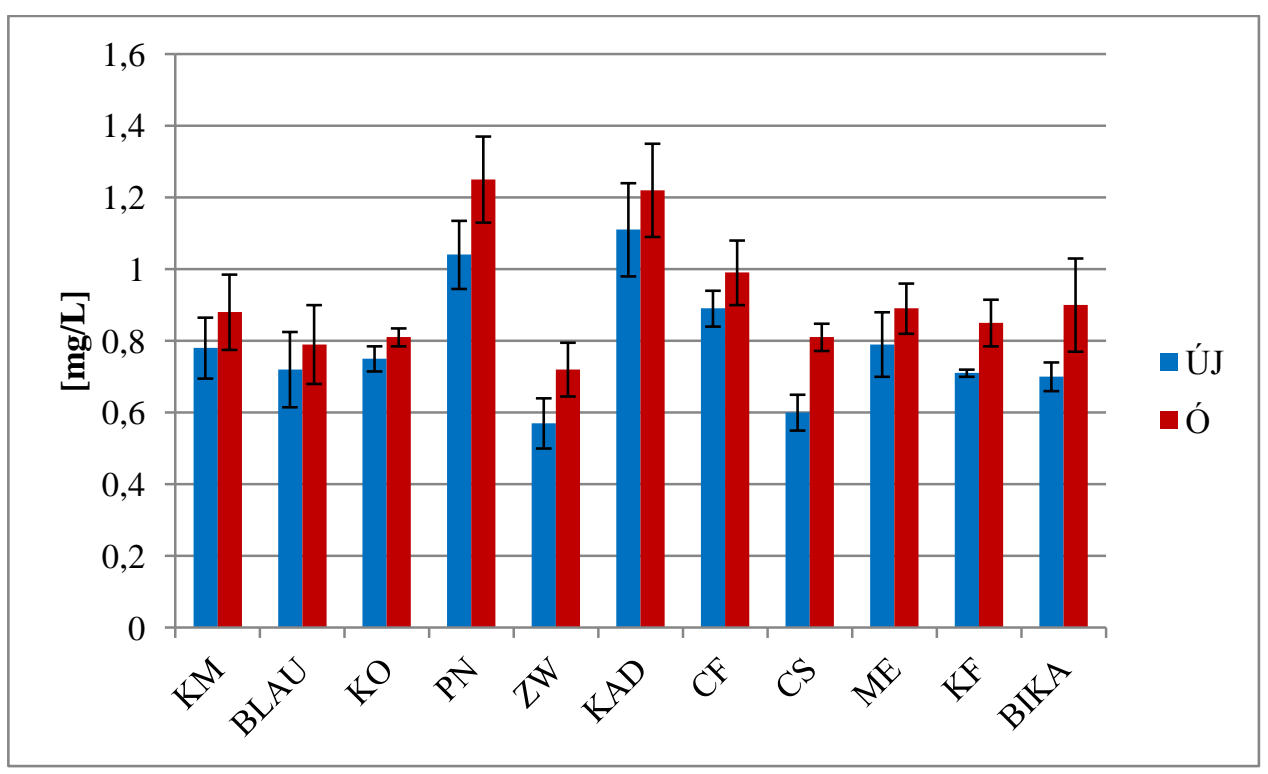

44. ábra: A borok színárnyalat (3 év átlaga)

Az újborok színárnyalata 0,57 és 1,11 értékek között változott. Az irodalmi adatoknak adódóan az egy feletti értékkel rendelkező borok barnatörésre hajlamosak. A Pinot noir és Kadarka fajták már újbor állapotban 1 feletti értékkel rendelkeztek.

Az érlelés hatására mindegyik borban emelkedett a színárnyalat értéke. A legalacsonyabb színárnyalatot a Zweigelt fajtánál mértem [0,72], ezzel az értékkel még egészséges a bor. A legmagasabb értéket a Pinot noir fajtánál mértem [1,25], ami már barnatöröttnek számít.

A szóráshomogenitás miatt a statisztika szignifikáns különbséget mutatott a Cabernet Sauvignon fajtánál.

\subsubsection{Sztilbén vegyületek}

A sztilbén családon belül négy vegyületet mértem: transz-piceid, cisz-piceid, transz-rezveratrol, cisz-rezveratrol. A három évjáratban nem mindegyik fajtánál volt kimutatható mindegyik forma, illetve az érlelés hatására az értékek változtak. A piceidekhez $\beta$-glükozidos kötéssel egy cukormolekula kapcsolódik, mely az erjedés és érlelés során rezveratrollá alakulhat.

Az évjáratok között különbségek léptek fel a rezveratrol tartalom szempontjából. A bor rezveratroltartalmát nagymértékben befolyásolja az évjárat: az UV-sugárzás, a hőmérséklet, a csapadék mennyisége és a napsütötte órák száma. 


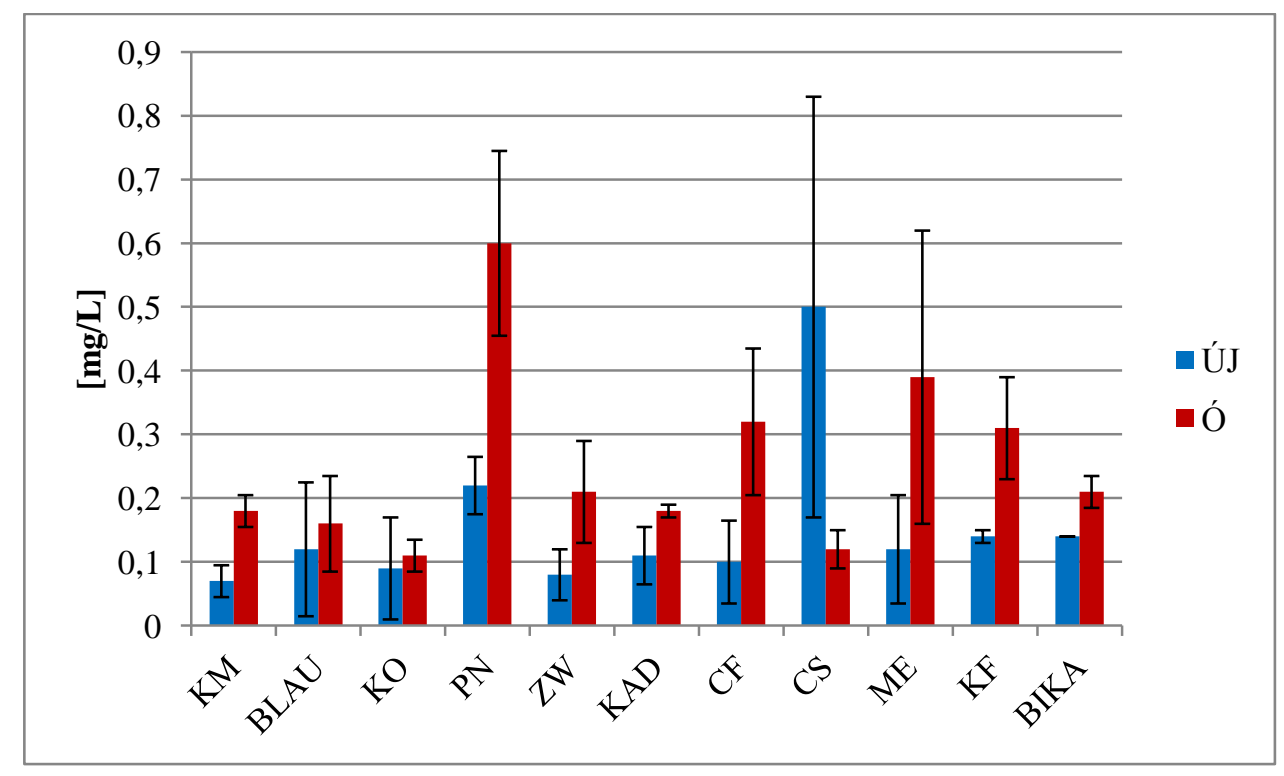

45. ábra: A borok transz-piceid tartalma (3év átlaga)

Három év átlaga alapján minden fajtában a transz-piceid tartalom az óborokban emelkedett. A szórások különbséget mutattak, viszont a statisztika szerint szignifikancia nem volt.

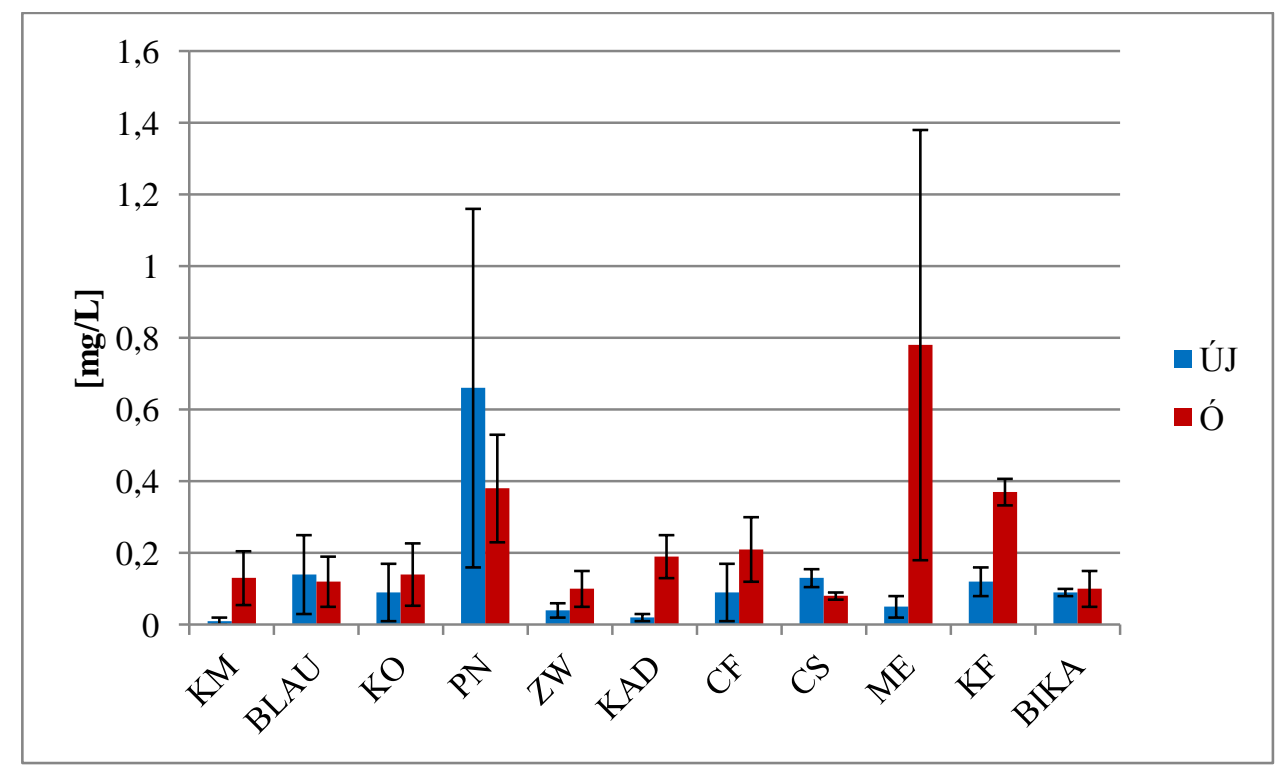

46.ábra: A borok cisz-piceid tartalma (3 év átlaga)

A cisz forma labilis. Nem mindegyik évjáratban és nem mindegyik fajtánál lehetett kimutatni a cisz formát. A transz formához képest változó a csökkenő és növekvő trend új és óborok között. 


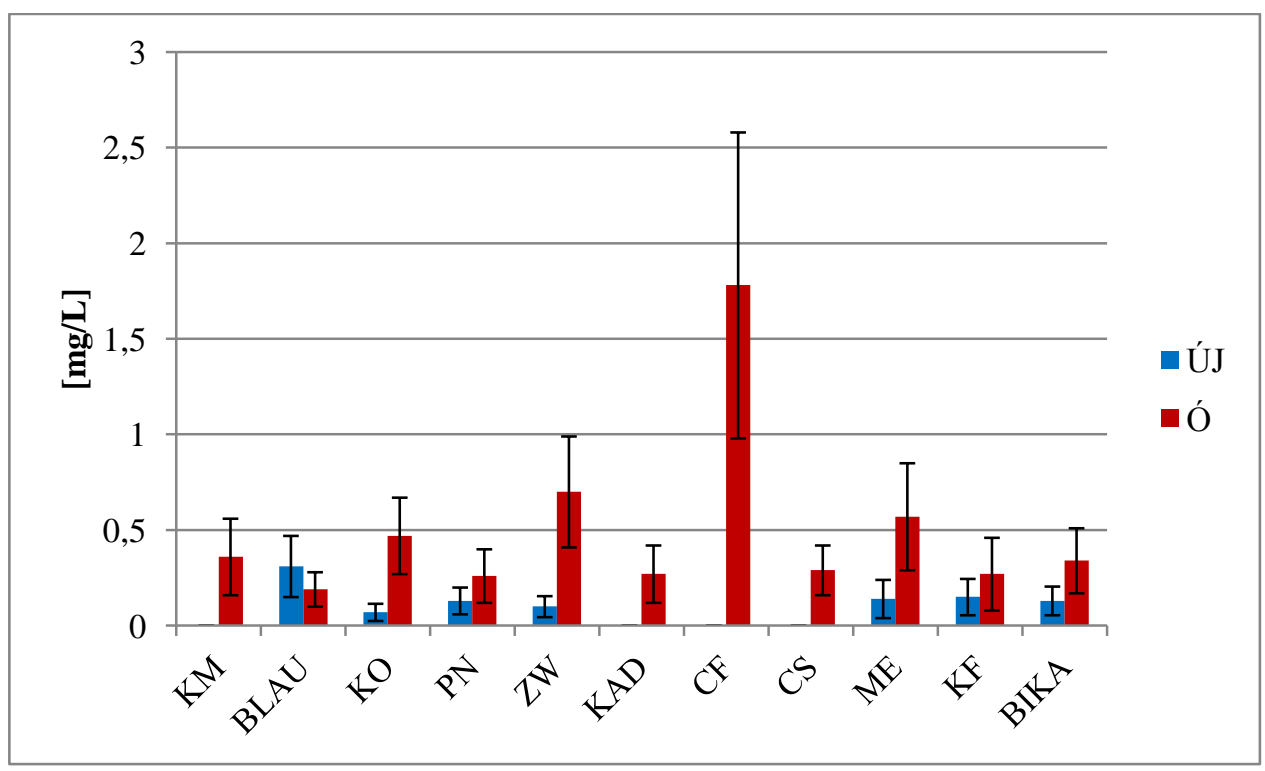

47.ábra: A borok transz-rezveratrol tartalma (3 év átlaga)

Három év alapján megállapítható, hogy nem mindegyik újborban lehetett transz-rezveratrolt detektálni. Viszont az óborokban, az érlelésnek köszönhetően, a piceides forma átalakult transzrezveratrollá. Kiemelkedő a Cabernet franc szőlőfajta, ugyanis újborban nem sikerült ezt a formát kimutatni, viszont az érlelt borban az összes többi fajtához képest kardinálisan kiemelkedik.

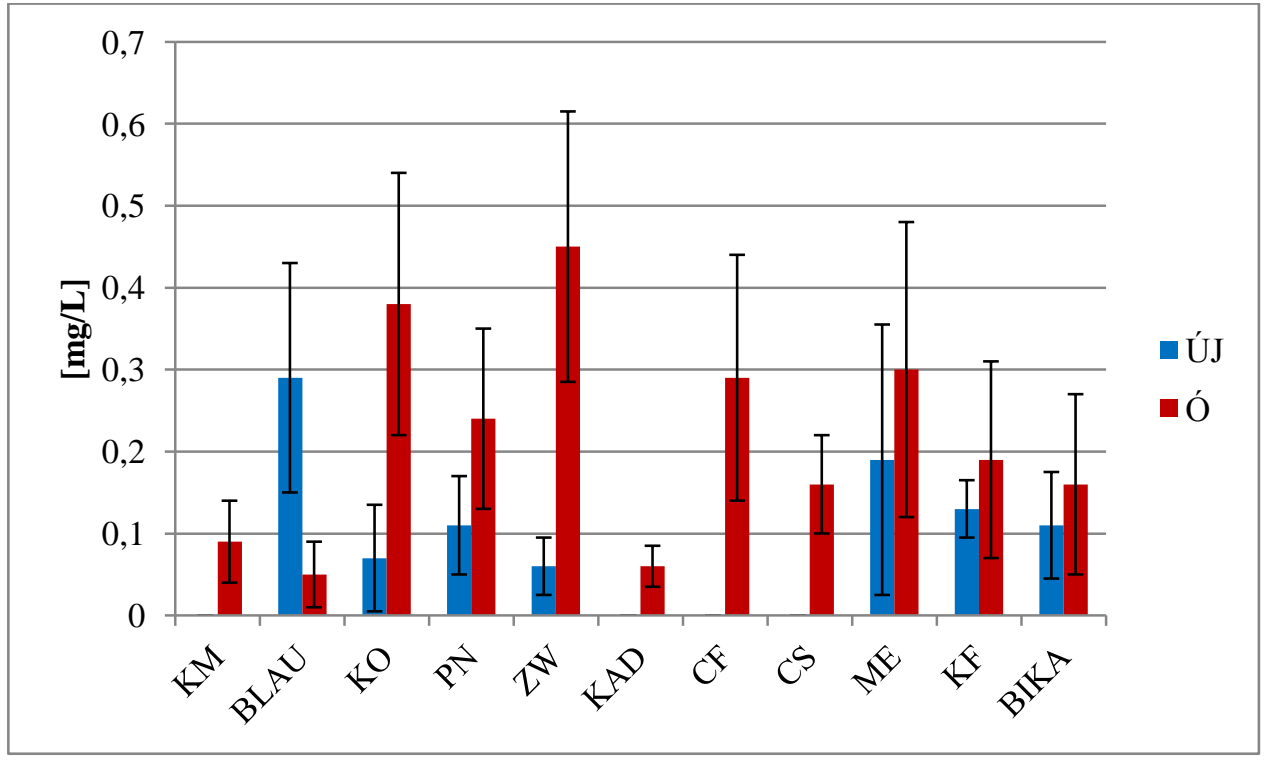

48.ábra: A borok cisz-rezveratrol tartalma (3 év átlaga)

A borok cisz-rezveratrol koncentrációja jóval alacsonyabb a transz-rezveratrolhoz képest. Az újborokban egyes mintákban nem tudtam detektálni ezt a formát. 


\subsection{Borok organoleptikus analízisének eredményei}

A borokat az analitikai vizsgálatokon kívül érzékszervileg is elemeztük. Mind a három évjáratban (2007, 2008, 2009) egy öt főből álló, szaktudással rendelkező bíráló bizottság értékelte a borokat újbor, és rá egy évre óbor állapotban. Bírálták az alapborokat és a házasított bort, a Bikavért. A bírálat 100 pontos módszerrel történt vakon. A 15. és 16. táblázat a 2007-es borok bírálati eredményeit mutatja be. Az eredmények átlagértékek.

15. táblázat: 2007-es újborok érzékszervi bírálati eredményei

\begin{tabular}{|l|c|c|c|c|c|c|c|c|c|c|c|}
\hline \multicolumn{1}{|c|}{2007 ÚJ } & KM & BLAU & KO & PN & ZW & KAD & CF & CS & ME & KF & BIKA \\
\hline SZV & 70,4 & 88,2 & 71 & 54,2 & 73 & 29,8 & 82 & 57,6 & 61,4 & 77,4 & 73,4 \\
\hline SZB & 12,2 & 12,8 & 21,6 & 25,6 & 9 & 57,6 & 13,2 & 23,6 & 29,4 & 11,6 & 22 \\
\hline ILLINT & 58,8 & 52 & 52,2 & 66,6 & 51,4 & 52 & 45,6 & 45,2 & 47,2 & 43,6 & 56,8 \\
\hline ILLM & 51,2 & 57,8 & 33,4 & 53 & 56 & 21,2 & 30,2 & 34,8 & 59,2 & 46,4 & 63,8 \\
\hline ILLGY & 50,6 & 25,4 & 25 & 38,6 & 47 & 20,6 & 27,2 & 36 & 38,2 & 44,8 & 45,8 \\
\hline ILLFÜ & 39,8 & 35,6 & 16,4 & 43,6 & 32,8 & 14,8 & 23,2 & 20,8 & 38,2 & 41,2 & 39,6 \\
\hline ILLFAJT & 66 & 48 & 14,6 & 39,6 & 37,6 & 11 & 11,6 & 25,8 & 56,6 & 55,2 & 33,4 \\
\hline ILLID & 8 & 16,6 & 59,6 & 22,6 & 14,4 & 63,6 & 41,8 & 38,6 & 7,8 & 15,8 & 12,6 \\
\hline ÍS & 44,6 & 38 & 37,4 & 50,6 & 48,2 & 56,4 & 53 & 41,4 & 35,2 & 41,4 & 40 \\
\hline ÍH & 39,3 & 27,6 & 37,8 & 57,6 & 45,2 & 53 & 44,2 & 34,4 & 35 & 39,4 & 39,6 \\
\hline ÍK & 24,2 & 13,6 & 17,6 & 31,8 & 18,6 & 21,8 & 18,6 & 20,8 & 23,8 & 30,2 & 30,6 \\
\hline ÍGY & 52,6 & 32,2 & 50,8 & 35 & 50,2 & 35,4 & 57,2 & 51 & 62,6 & 45,2 & 41 \\
\hline ÍM & 57,2 & 52,2 & 51 & 38,6 & 55,6 & 36,4 & 50,6 & 50,6 & 70,2 & 52 & 53 \\
\hline ÍID & 8,8 & 8,2 & 19,2 & 29,6 & 11 & 31,6 & 19,6 & 22 & 8,6 & 17,4 & 14,6 \\
\hline ÍHA & 57,4 & 56,6 & 44 & 36,4 & 50 & 34,8 & 45,6 & 47 & 69 & 53,4 & 56,4 \\
\hline
\end{tabular}


16. táblázat: 2007-es óborok érzékszervi bírálati eredményei

\begin{tabular}{|l|c|c|c|c|c|c|c|c|c|c|c|}
\hline 2007 Ó & KM & BLAU & KO & PN & ZW & KAD & CF & CS & ME & KF & BIKA \\
\hline SZV & 95 & 93 & 80 & 62 & 92,5 & 20 & 76 & 96 & 68 & 87 & 90 \\
\hline SZB & 8 & 3 & 10 & 38 & 3 & 30 & 24 & 4 & 35 & 9 & 10 \\
\hline ILLINT & 91 & 77,5 & 70 & 57 & 71 & 80 & 87 & 77 & 72,5 & 67 & 80 \\
\hline ILLM & 79 & 56 & 70 & 65 & 65 & 80 & 74 & 80 & 60 & 62 & 80 \\
\hline ILLGY & 75 & 64 & 60 & 58 & 72 & 30 & 79 & 77,5 & 60 & 55 & 70 \\
\hline ILLFÜ & 63 & 40 & 30 & 55 & 55 & 90 & 52 & 47,5 & 48 & 42 & 40 \\
\hline ILLFAJT & 80 & 57 & 50 & 58 & 75 & 90 & 63 & 62 & 55 & 63 & 70 \\
\hline ILLID & 3 & 24 & 10 & 11 & 8 & 10 & 8 & 0 & 22,5 & 8 & 10 \\
\hline ÍS & 73 & 57 & 100 & 70 & 42 & 100 & 73 & 75 & 67,5 & 63 & 90 \\
\hline ÍH & 76 & 62,50 & 90 & 65 & 55 & 90 & 78 & 67,5 & 67,5 & 67 & 90 \\
\hline ÍK & 18 & 3 & 0 & 37 & 23 & 0 & 15 & 14 & 14 & 28 & 5 \\
\hline ÍGY & 82 & 60 & 70 & 53 & 63 & 60 & 73 & 68 & 68 & 60 & 80 \\
\hline ÍM & 79 & 56 & 80 & 62 & 63 & 80 & 70 & 68 & 68 & 64 & 90 \\
\hline ÍID & 0,8 & 16 & 0 & 10 & 3 & 0 & 3 & 10 & 10 & 7 & 0 \\
\hline ÍHA & 80 & 60 & 90 & 63 & 58 & 90 & 75 & 72 & 72 & 63 & 95 \\
\hline
\end{tabular}

Új- és óbor állapotban több paraméter szerint elemezték a bírák a borokat. A borok között nagy különbségek voltak, mind a fajták között, mind pedig az érleltségi állapotok között. A 2007-es évjáratban az óborok illat- és ízminőség szempontjából is magasabb pontszámot kaptak, mint újbor állapotukban. Az idegen illat tekintetében újborként a bírák magasabb pontszámokat adtak, ami betudható a bor nyerseségének és éretlenségének is. Óborként az ízek, illatok finomodtak, és az idegen illatok nem érezhetőek már. A 17. és 18. táblázatban a 2008-as borok bírálati eredményei láthatóak. 
17. táblázat: 2008-as újborok érzékszervi bírálati eredményei

\begin{tabular}{|l|c|c|c|c|c|c|c|c|c|c|c|}
\hline 2008 ÚJ & KM & BLAU & KO & PN & ZW & KAD & CF & CS & ME & KF & BIKA \\
\hline SZV & 78,33 & 93,33 & 73,33 & 53,33 & 82,5 & 48,33 & 52,5 & 88,33 & 69,16 & 74,16 & 75,5 \\
\hline SZB & 12,5 & 8,33 & 10 & 37,5 & 6,66 & 43,33 & 8,33 & 7,5 & 5 & 12,5 & 6,66 \\
\hline ILLINT & 91,33 & 71,33 & 75 & 60,83 & 71,66 & 78,33 & 79,16 & 76,66 & 62,5 & 73,66 & 73 \\
\hline ILLM & 85 & 73,33 & 73,33 & 63,33 & 71,66 & 77,16 & 75 & 65,82 & 70,83 & 70,83 & 74,16 \\
\hline ILLGY & 79,66 & 72 & 71,66 & 61,66 & 69,16 & 69,16 & 84,16 & 72 & 71,33 & 70,5 & 76,16 \\
\hline ILLFÜ & 70,33 & 38,33 & 47,5 & 55 & 33,33 & 78,33 & 36,66 & 46,66 & 30 & 43,33 & 58,83 \\
\hline ILLFAJT & 95 & 62,5 & 76,66 & 8,3 & 67,5 & 84,16 & 51,66 & 53,33 & 59,16 & 70 & 43,33 \\
\hline ILLID & 0 & 7,5 & 3,33 & 22,6 & 1,66 & 10 & 0 & 8,33 & 2,16 & 6,66 & 5 \\
\hline ÍS & 73,33 & 69,33 & 65,83 & 60 & 58,33 & 59,16 & 62,5 & 61,66 & 64,16 & 64,16 & 64,16 \\
\hline ÍH & 79,66 & 65,83 & 45 & 65 & 53,33 & 67,5 & 45 & 60,83 & 52,5 & 61,66 & 67,5 \\
\hline ÍK & 11,66 & 20,83 & 15 & 22,5 & 20,83 & 24,16 & 8,33 & 13,33 & 5 & 11,66 & 12,5 \\
\hline ÍGY & 64,16 & 65 & 64,16 & 40,83 & 57,5 & 55,83 & 77,5 & 59,16 & 63,33 & 65 & 58,33 \\
\hline ÍM & 77,5 & 71,66 & 62,5 & 57 & 59,16 & 70 & 62,5 & 62,16 & 66,6 & 64,16 & 66,66 \\
\hline ÍID & 1,66 & 5,83 & 1,66 & 5 & 13,33 & 10 & 1,66 & 10 & 3,33 & 3,33 & 1,66 \\
\hline ÍHA & 72,5 & 68,33 & 60,83 & 67,83 & 55,5 & 57,5 & 69,66 & 58,33 & 65,33 & 63 & 64,16 \\
\hline
\end{tabular}

18. táblázat: 2008-as óborok érzékszervi bírálati eredményei

\begin{tabular}{|l|c|c|c|c|c|c|c|c|c|c|c|}
\hline 2008 Ó & KM & BLAU & KO & PN & ZW & KAD & CF & CS & ME & KF & BIKA \\
\hline SZV & 74 & 92,5 & 64 & 37,5 & 70 & 40 & 38 & 84 & 67 & 69 & 64 \\
\hline SZB & 29 & 16 & 19 & 61 & 22 & 50 & 34 & 11 & 17,5 & 29 & 27,5 \\
\hline ILLINT & 86 & 70 & 69 & 55 & 69 & 69 & 82 & 71 & 73 & 62,5 & 72,5 \\
\hline ILLM & 80 & 71 & 67 & 65 & 67,5 & 71 & 77,5 & 72 & 77 & 64 & 71 \\
\hline ILLGY & 71 & 69 & 71 & 59 & 62 & 61 & 78 & 70 & 72 & 57 & 66 \\
\hline ILLFÜ & 60 & 50 & 42,5 & 58 & 46 & 77,5 & 56 & 44 & 48 & 55 & 56 \\
\hline ILLFAJT & 91 & 67 & 65 & 58 & 67 & 79 & 52 & 49 & 66 & 63 & 72 \\
\hline ILLID & 7 & 8 & 13 & 7 & 17 & 12 & 9 & 7 & 10 & 16 & 10 \\
\hline ÍS & 87,5 & 82 & 67,5 & 75 & 66 & 78 & 71 & 68 & 74,5 & 71 & 76 \\
\hline ÍH & 78 & 77 & 64 & 75 & 62,5 & 77,5 & 73 & 68 & 72,5 & 75 & 77 \\
\hline ÍK & 29 & 36 & 26 & 37 & 28 & 27 & 36 & 27 & 22 & 34 & 27 \\
\hline ÍGY & 57,5 & 75 & 67 & 59 & 64,5 & 55 & 74 & 69 & 72,5 & 57 & 66 \\
\hline ÍM & 75 & 73 & 64 & 65 & 62 & 69 & 67,5 & 69 & 72,5 & 64 & 72 \\
\hline ÍID & 7 & 7 & 10 & 7 & 11 & 8 & 8 & 8 & 7 & 8 & 7 \\
\hline ÍHA & 78 & 75 & 68 & 69 & 61,5 & 66 & 71 & 69 & 75,5 & 64 & 70 \\
\hline
\end{tabular}

A színintenzitás és színárnyalat analitikai eredményei megmutatkoznak az organoleptikus eredményekben is. A 2008-as évjáratban is az érlelés hatására minden egyes bor színtónusa mélyült, enyhén barnult, melyet a bírák is észrevettek. Újbor állapotban a színek élénkebbek, intenzívebbek voltak, de egyik bornál sem mutatkozott szín szempontjából negatív, minőségbeli 
romlás. A borok az érleltség hatására harmonikusabbá váltak, bár olyan nagy különbség nem volt a harmónia tekintetében 2008-ban, mint 2007-ben újbor és óbor között. A 2009-es évjárat borainak bírálati eredményeit a 19 . és 20 . táblázat mutatja be.

19. táblázat: 2009-es újborok érzékszervi bírálati eredményei

\begin{tabular}{|l|c|c|c|c|c|c|c|c|c|c|c|}
\hline 2009 ÚJ & KM & BLAU & KO & PN & ZW & KAD & CF & CS & ME & KF & BIKA \\
\hline SZV & 84 & 98 & 93 & 62 & 93 & 65 & 90 & 99 & 93 & 90 & 95 \\
\hline SZB & 10 & 1 & 3 & 44 & 3 & 13 & 6 & 2 & 4 & 3 & 3 \\
\hline ILLINT & 77 & 66,6 & 70 & 61 & 74 & 72 & 79 & 79 & 79,6 & 78 & 75 \\
\hline ILLM & 80 & 63 & 47 & 71 & 72 & 75 & 82 & 71 & 75 & 79 & 72 \\
\hline ILLGY & 78 & 69 & 55 & 65 & 70,2 & 75 & 77 & 68 & 69 & 77 & 68 \\
\hline ILLFÜ & 51 & 40 & 47 & 57 & 57,4 & 71 & 69 & 57 & 49 & 52 & 62 \\
\hline ILLFAJT & 69 & 72 & 45 & 66 & 73 & 59 & 79 & 61 & 71 & 77 & 47 \\
\hline ILLID & 8 & 20 & 54 & 12 & 14 & 10 & 4 & 12 & 12 & 9 & 20 \\
\hline ÍS & 79 & 70 & 67 & 76 & 71 & 73 & 86 & 79 & 81 & 74 & 80 \\
\hline ÍH & 66 & 66 & 65 & 74 & 71 & 71 & 82 & 74 & 79 & 73,2 & 79 \\
\hline ÍK & 7 & 10 & 7 & 23 & 10 & 15 & 11 & 12 & 8 & 8 & 6 \\
\hline ÍGY & 80 & 72 & 59 & 66 & 72 & 73 & 81 & 76 & 78 & 88 & 72 \\
\hline ÍM & 78 & 73 & 58 & 69 & 71 & 69 & 88 & 78 & 77 & 76 & 75 \\
\hline ÍID & 8 & 7 & 17 & 10 & 8 & 10 & 3 & 6 & 3 & 8 & 6 \\
\hline ÍHA & 76 & 73 & 49 & 68 & 71 & 72 & 87 & 75 & 79 & 77 & 76 \\
\hline
\end{tabular}

20. táblázat: 2009-es óborok érzékszervi bírálati eredményei

\begin{tabular}{|l|c|c|c|c|c|c|c|c|c|c|c|}
\hline 2009 Ó & KM & BLAU & KO & PN & ZW & KAD & CF & CS & ME & KF & BIKA \\
\hline SZV & 85 & 96,8 & 91 & 67 & 85 & 60 & 91 & 97 & 86,4 & 91 & 92 \\
\hline SZB & 18 & 2 & 4 & 33 & 5 & 26 & 6 & 2 & 9 & 8 & 4 \\
\hline ILLINT & 78 & 61 & 71 & 57 & 73 & 71 & 85 & 79 & 77 & 75 & 82 \\
\hline ILLM & 70 & 67 & 61 & 52 & 62 & 77 & 88 & 79 & 84 & 60 & 80 \\
\hline ILLGY & 72 & 66 & 74 & 58 & 60 & 70 & 78 & 67 & 75 & 70 & 80 \\
\hline ILLFÜ & 62 & 54 & 52 & 54 & 31 & 72 & 72 & 72 & 72 & 32 & 57 \\
\hline ILLFAJT & 76 & 83 & 70 & 43 & 72 & 72 & 83 & 78 & 82 & 62 & 74 \\
\hline ILLID & 7 & 8 & 22 & 32 & 14 & 8 & 3 & 3 & 3 & 24 & 2 \\
\hline ÍS & 71 & 78 & 57 & 72 & 71 & 70 & 80 & 81 & 83,6 & 67 & 74 \\
\hline ÍH & 62 & 67 & 54 & 60 & 65 & 58 & 83 & 82 & 73 & 68 & 76 \\
\hline ÍK & 10 & 6 & 11 & 19 & 8 & 17 & 6 & 8 & 6 & 14 & 6 \\
\hline Í́GY & 68 & 71 & 60 & 54 & 67 & 66 & 79 & 80 & 75 & 67 & 76 \\
\hline ÍM & 69 & 75 & 51 & 63 & 71 & 74 & 87 & 82 & 76 & 66 & 80 \\
\hline ÍID & 6 & 8 & 28 & 14 & 8 & 8 & 2 & 2 & 6 & 20 & 2 \\
\hline ÍHA & 70,6 & 79 & 61 & 60 & 74 & 79 & 87 & 81,2 & 81 & 63 & 76,6 \\
\hline
\end{tabular}


A 2009-es évjárat az előzőekhez képest kiemelkedőbbnek mondható, ami a kémiai eredményeken kívül az érzékszervi bírálatban is megmutatkozott. A bírák már újborként is magas pontokat adtak a boroknak, annak ellenére, hogy azok még nyersek voltak, a savaik még nem finomodtak le. Az illatminőség paramétereit figyelembe véve egyes borokat [KM; PN; ZW; $\mathrm{KF}$ ] a bírák újbor állapotban magasabb pontszámmal illették, mint érlelt borként. Az ízminőség szempontjából a bírák a KM, PN, KO és KF fajtákat újborként jobbra értékelték, mint óborként. A színek változása ebben az évben is a várt eredményeket hozta, az érlelt borok színtónusa mind érzékszervileg, mind analitikailag magasabb eredményekkel bírt.

\subsubsection{Az érlelés hatása a 2007-es Egri Bikavér érzékszervi tulajdonságaira}

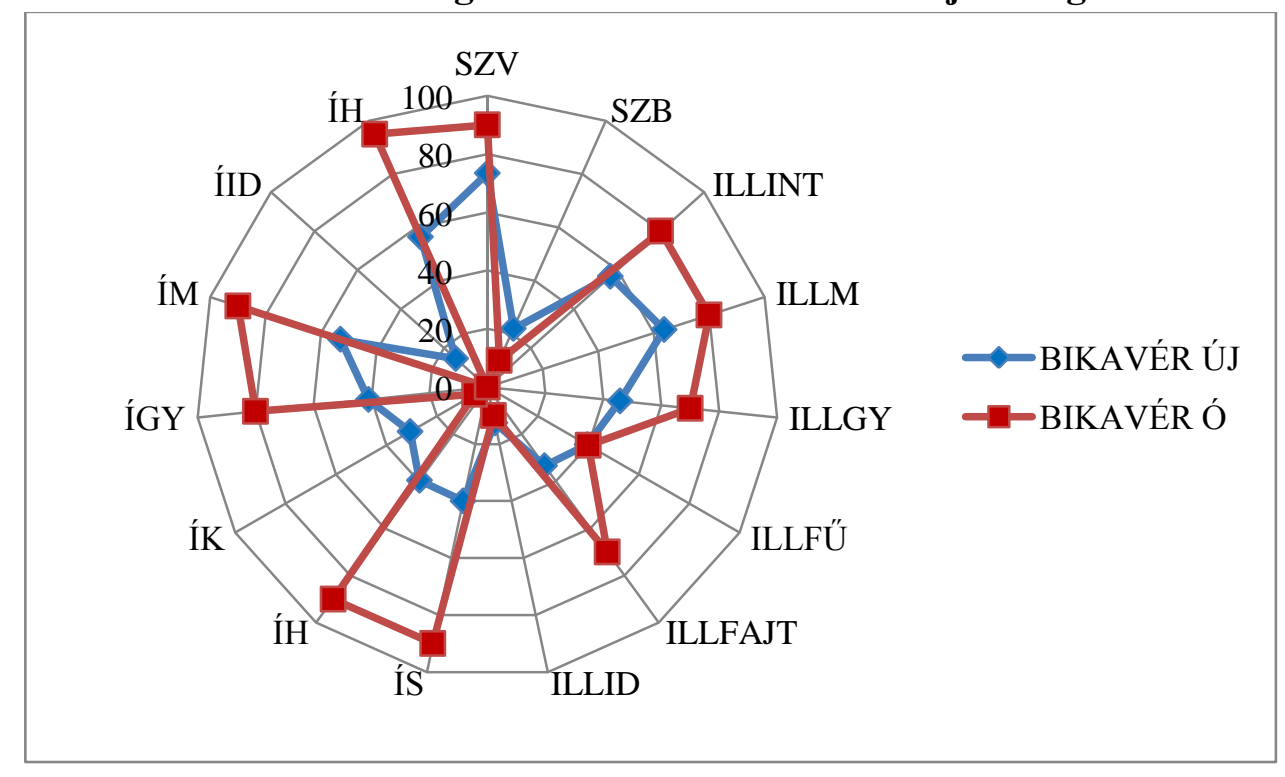

49. ábra: 2007-es Egri Bikavér profildiagramja

Mind a három évjáratban a házasítást elvégeztem az új alapborokból, ami rögtön érzékszervileg bírálat alá esett, majd egy évre rá újra lebírálták a bírák a házasítást.

A kék színnel az újborok bírálati eredményei láthatóak, míg a vörös szín az óborokat ábrázolja. Színintenzitás szempontjából a bírák az érlelt Bikavérnek magasabb pontot adtak, véleményük szerint nem barnult, mélyült a bor színe, vörösségét, élénkségét egy évre rá is megtartotta. Illat szempontjából intenzívebbé, gyümölcsösebbé, minőségibbé vált a Bikavér. Az érlelés hatására a savak finomodtak, a fenolos húzósság komplexszé vált, idegen ízt nem éreztek a borban, valamit a 2007-es évjáratban az ó Bikavér gyümölcsössé, harmonikussá vált. 


\subsubsection{Az érlelés hatása a 2008-as Egri Bikavér érzékszervi tulajdonságaira}

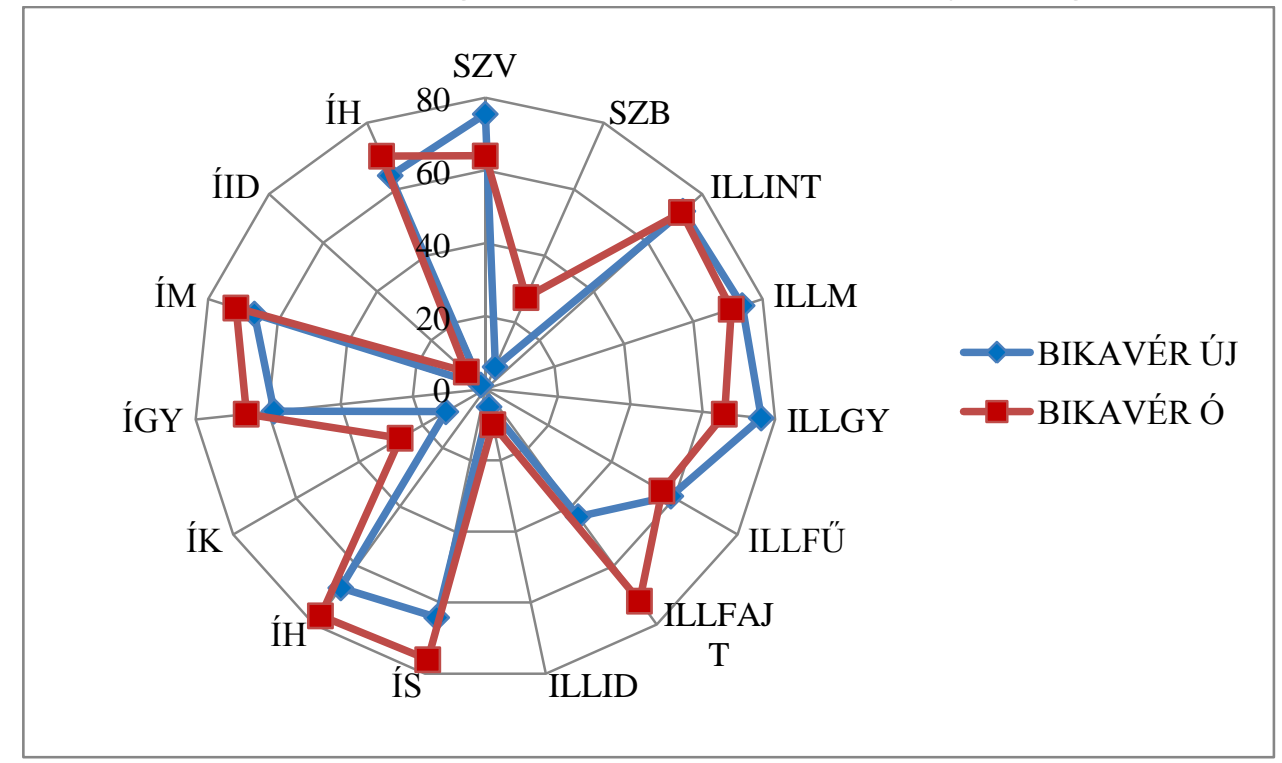

50.ábra: 2008-as Egri Bikavér profildiagramja

A 2008-as évjáratban, ahogy a profildiagram is mutatja, az érlelés hatására kiemelkedő eltérések nem mutatkoztak. Ebben az évben az óbor veszített vörös színéböl, az oxidáció fellépett az érlelés hatására, így enyhe barna tónust kapott a házasítás. Az illat intenzitása nem csökkent az új állapothoz képest, a többi illattulajdonság pedig szinte megegyezik az új- és az óborokban. Ebben az évjáratban is finomodtak a savak, valamint a fenolos keserüség is, ami által a bor harmonikusabbá vált.

\subsubsection{Az érlelés hatása a 2009-es Egri Bikavér érzékszervi tulajdonságaira}

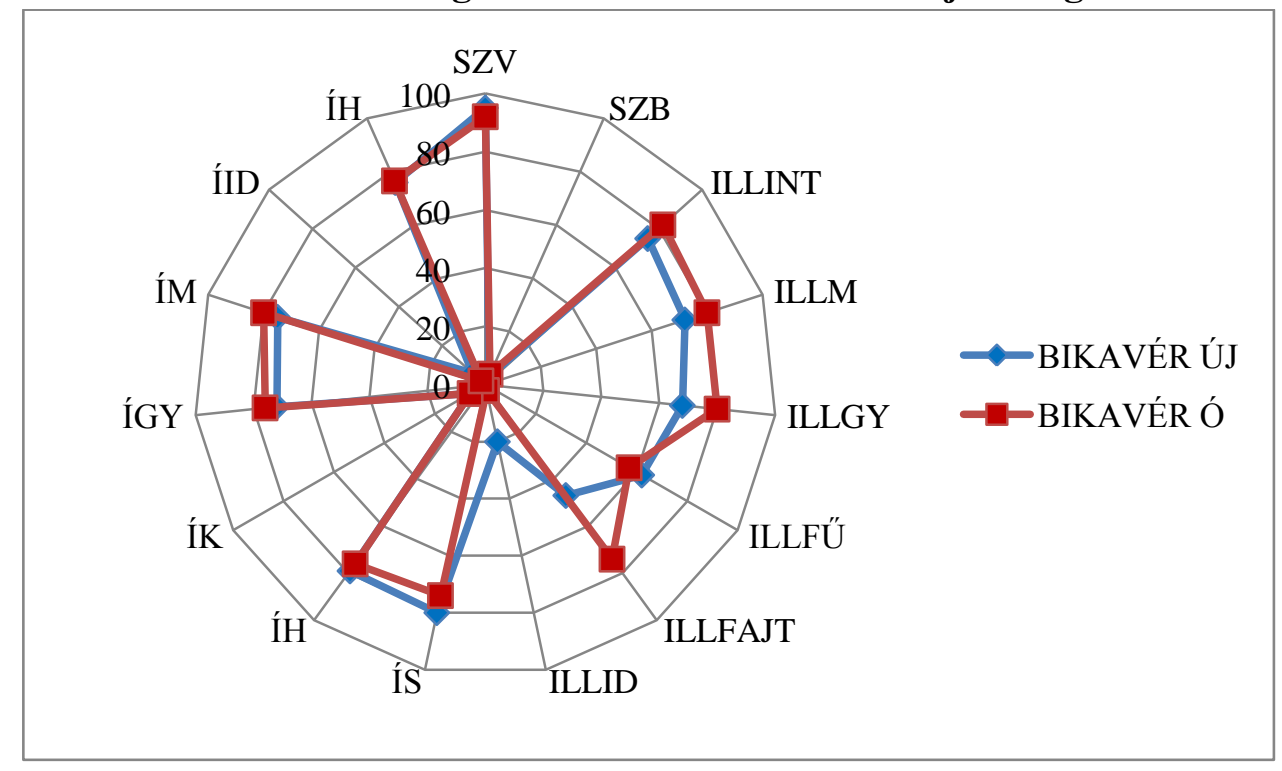

51.ábra: 2009-es Egri Bikavér profildiagramja 
A 2009-es évben, ahogy a pókhálódiagram is mutatja, nagy az átfedés az új és ó Bikavérek között. A színintenzitást és tónust a bírák szinte ugyanúgy értékelték mind a két állapotban. Az illatintenzitás, gyümölcsösség és minőség szempontjából az érlelt Bikavér magasabb pontszámot kapott. Az idegen illatban az újbort minősítették magasabbra, de az alapborok esetében is ez volt jellemző ebben az évjáratban, ami még a nyerseségnek, éretlenségnek tudható be. Az íz tulajdonságaiban az új és ó Bikavérek megegyeztek.

Mind a három évjáratban az érzékszervi paraméterek szoros összefüggésben vannak a rutinanalitikai és fenolos eredményekkel. Minden egyes vegyület befolyásolja az érzékszervi tulajdonságokat. Ahogyan a fenolos vegyületek is, az érzékszervi attribútumok is változtak az érlelés hatására. Ezek a változások megmutatkoztak a Bikavért adó alapborokban is, valamint a házasított borban, a Bikavérben is. 


\section{KÖVETKEZTETÉSEK}

Munkám során az Egri Bikavért adó szőlőfajtákat, a belőlük készült alapborokat és a házasított Bikavért mélyreható analitikai és érzékszervi vizsgálatokkal tanulmányoztam.

Az évjárat jelentősen befolyásolja a szőlő és a bor minőségét. A disszertációmban közölt mérési eredmények alapján állíthatjuk, hogy a szőlőfürt különböző részeiben eltérő mennyiségben és minőségben lokalizálódnak a fenolos vegyületek, melyet az évjárat és fajtahatás meghatározóan befolyásol. Az adott fajták többéves tanulmányozása és analitikai feltérképezése lehetőséget ad különböző terméskorlátozási módszerek javaslattételére, melynek köszönhetően optimalizálni tudjuk a szőlő termesztéstechnológiáját a fenolos vegyületek tekintetében.

Kutatásaim három egymást követő évjáratban zajlottak. Vizsgálataim egyik releváns célja az érlelés hatásának analizálása volt. Mérési eredményeim arra engednek következtetni, hogy mindegyik évjáratban jelentős és pozitív hatást gyakorol az érlelés a borok fenolos és érzékszervi tulajdonságaira. A házasítás és az érlelés pozitívan befolyásolja a minőségi Egri Bikavér elkészítését. Az eredmények alapján megállapíthatjuk, hogy kémiai paraméterek szoros korrelációban vannak az organoleptikus mutatószámokkal. A fenolos vegyületek jelenléte kardinálisan meghatározza az Egri Bikavér érzékszervi tulajdonságait. Az Egri Bikavér minőségfejlesztése szempontjából fontos mélyreható kémiai és érzékszervi ismeretekkel rendelkezni. 


\section{8. ÚJ TUDOMÁNYOS EREDMÉNYEK}

1. Kutatásaim során az Egri Bikavért adó szőlőfajták bogyóhéj-extarktumának finomösszetételét vizsgáltam három évjáratban.

Megállapíthatom, hogy a fajták között az élettanilag aktív vegyületek mennyiségbeli és minőségbeli vonatkozásában különbségek mutatkoztak. A fajtáknál más fürtrészekben lokalizálódtak a fenolos vegyületek.

Kísérletem során a szőlőfürtöket matematikailag három egyenlő részre osztottam, és az élettanilag aktív vegyületek mennyiségét és minőségét vizsgáltam a fürtrészekben.

Évjáratonként és fajtánként más-más helyen akkumulálódtak nagyobb mennyiségben a fenolos vegyületek. Főként az évjáratnak van jelentős hatása a vegyületek fürtön belüli eloszlására. A 2008-as évjáratban mind a három szőlőfajtánál eltérő helyen lokalizálódtak nagyobb mennyiségben az élettanilag aktív vegyületek, míg a 2009-es évben három eltérő szőlőfajtát elemeztem, de mind a három fajtánál a váll részben voltak nagyobb mennyiségben felfedezhetőek ezek a vegyületek.

2. Méréseim során az Egri Bikavért adó szőlőfajták borainak szisztemizáló elemzését végeztem három évjáratban.

Megállapítható, hogy a Bikavért adó tíz szőlőfajta a statisztikai elemzés szerint is szignifikánsan eltért egymástól mind rutinanalitikai, mind pedig a müszeres analitikai eredmények tekintetében. Az élettanilag aktív vegyületek mennyisége mindegyik évjáratban változott, amit a statisztika is alátámasztott.

3. Kutatásom során vizsgáltam az érlelés hatását a Bikavért adó alapborokra.

Megállapítható, hogy mind a három évjáratban a fenolos komponensek koncentrációjának tekintetében különbségek voltak kimutathatóak, amelyeket a statisztika szignifikánsan alátámasztott. Az érlelés szerepének nagy jelentősége van a minőségi Egri Bikavér szempontjából.

4.Az alapborokat újbor, illetve érlelt bor állapotában organoleptikus analízis alá vettem három évjáraton keresztül.

Az érzékszervi bírálati eredmények alapján a fajták között elérések mutatkoztak, az érlelés pedig pozitívan befolyásolta a borok szenzorikus tulajdonságait. Korreláció figyelhető meg az analitikai paraméterek és az érzékszervi attribútumok között. 
5. Dolgozatom során három évjáraton keresztül az Egri Bikavér élettanilag aktív vegyületeit, illetve az érlelés hatását vizsgáltam az alapanalitikai és fenolos paraméterek vonatkozásában.

Megállapítható, hogy szükséges az alapborok mélyebb szintü kémiai ismerete, melyekből a házasítás készül, ugyanis így lehet optimálisan elkészíteni a Bikavért. Mind a három évjárat hatással volt az Egri Bikavér élettanilag aktív vegyületeire, melynél a statisztikai kiértékelés szignifikáns differenciát mutatott.

$\mathrm{Az}$ érlelés hatással volt az Egri Bikavér alapanalitikai és fenolos paramétereire egyaránt. Megállapítható, hogy mind a két mutatószámra, mind a három évjáratban pozitív változást eredményezett az érlelés.

6. A kémiai vizsgálatokon kívül az Egri Bikavér érzékszervi tulajdonságait is feltérképeztem három évjáratban, és az érlelés hatását vizsgáltam.

Az érzékszervi eredmények szoros kapcsolatban álltak az analitikai paraméterekkel. A bírálók a Bikavért minden évben pozitívan bírálták el. Az évjáratok között szignifikáns különbség mutatkozik, valamint az érlelések között is eltérés mutatkozik, föként a 2007-es évjáratban. A 2009-es évben viszont organoleptikus szempontból nagyok az átfedések, ami az évjárathatásnak tudható be. 


\section{9. ÖSSZEFOGLALÁS}

A bor minőségének kialakulásában számtalan tényező együttes hatása játszik. Az egyik legmeghatározóbb paramétere a szőlő minősége. A szőlő minősége a bor minőségében érvényesül. A minőségi borok iránti kereslet növekedése, valamint a harmadik világ versenyképes borainak megjelenése a hazai piacon szinte megköveteli az Egri Bikavér szőlőfajtáinak, illetve a belőlük készült borok alapos analitikai és érzékszervi tulajdonságainak megismerését, ugyanis e tényezők birtokában tökéletesíteni lehet az Egri Bikavér szőlészeti és borászati technológiáit. Az Egri Bikavér minőségfejlesztésével új utak nyílnak a szőlő- és borgazdaságban, és méltóan viselheti a zászlós bor szerepét az Egri borvidéken.

Kutatásom során a feldolgozás, a borok kezelése, a házasítás és az érlelés a KRF Szőlészeti és Borászati Kutatóintézetében történt. A kísérleteket három egymást követő évjáratban 2007 és 2009 között végeztem. A vizsgált minták az ültetvény három véletlenszerüen kiválasztott tőkéjéről lettek leszüretelve. A fürtök azonos kitettségűek voltak, melyeknek a bogyóhéját vizsgáltam. A technológiai folyamat során egy újborként házasított Bikavért vizsgáltam, majd pedig az érlelés hatását a fenolos vegyületek változása szempontjából, valamint az élettanilag aktív vegyületek mennyiségi és minőségi jelenlétét tanulmányoztam, hogy az alapborokat külön érleltem és azt követően házasítottam. A kémiai és érzékszervi analíziseket a Budapesti Corvinus Egyetem Borászati Tanszékén végeztem el. A vizsgálatok során számos komponens kémiai analízisére került sor: a bogyóhéjakból összespolifenol-, antocianin-, leukoantocianin-, katechinés rezveratroltartalmat, a mustokban alapanalízist, a borokban alapanalízist és fenolos komponenseket vizsgáltam. Az analitikai paraméterek mellett a borok érzékszervi tulajdonságait is tanulmányoztam.

Az eredmények alapján megállapítottam, hogy a különböző szőlőfajták szőlőhéjkivonataiban az élettanilag aktív vegyületek mennyiségi és minőségi vonatkozásában különbségek mutatkoztak. A fürtrészekben fajtánként más-más helyen akkumulálódtak a fenolos vegyületek. Ezen adatok birtokában különböző terméskorlátozási módszerek javasolhatóak. A Bikavért adó alapborok mind rutinanalitikai, mind pedig müszeres analitikai eredmények tekintetében szignifikánsan eltérnek egymástól. A fajtán kívül az évjárat befolyásolja a polifenolok koncentrációját. Az érlelésnek kardinális és pozitív szerepe van a minőségi bor elkészítése szempontjából. Mind a három évjáratban az analitikai és érzékszervi mutatószámokra pozitív változást eredményezett az érlelés. 


\section{SUMMARY}

The development of wine quality combined effect of a number of factors is involved. One of the most significant parameter for the quality is the grape. The quality of grape is preaviled in quality of wine. Increase in demand for quality wines, and the world's third competitive appearance of wine in the domestic market requires that we have known the analytical and sensory properites of the Bull's Blood grapes and wines. Possession of these factors we can improve the Bull's Blood wine-growing and wine-making technologies. The Bull's Blood developing are opened new opportunity in the economy of grapes and wines and Bull's Blood of Eger worthy of wearing the flagship wine of Eger wine region.

During my research, the processing, the wine treatment, the blending and aging were contucted at the KRF Research Institute of Viticulture and Enology. The experiments were carried out in three years between 2007 and 2009. The samples were randomly harvested. The clusters were same and investigated the berry skin. During the process were investigated a new blending wine. We carries out the ageing effect and sensory and analitical parameters. The experiments were conducted at the Corvinus University of Budapest, Depertment of Oenology. During the tests of chemical analysis of several componets were carried out in berry skin extracts: total polyphenolics, anthocyanin, leucoanthocyanin, catechin and resveratrol, a main analysis of musts, phenolic analysis and main analysis of the wine. In addition to the determation of the chemical concentration the sensory properties were investigated.

According to the results the phenolic compounds in the berry skin extracts are presented a different rate. The phenolic compounds are accumulated in the different places of the clusters. Using this information we can propose the different methods of crop regulation. The basic wines of Bull's Blood were varied from main analitical as well as instrumental analytical results. In addition to the grape of vintage influences the concentration of polyphenols. The ageing process has a positive and cardinal role in a winemaking technology. The ageing were resulted a positive changes for the analytical and sensory ratios in all vintages. 


\section{IRODALOMJEGYZÉK}

ADAMS, J.B. (1973): Thermal degradation of anthocyanins with particular reference to the 3glycosides of cyanidin in acidified aqueous solution at $100{ }^{\circ}$ C. J. Sci. Food. Agric. 24:747-762. http://dx.doi.org/10.1002/jsfa.2740240702 .

AMATI, A. (1991): Kerekasztal beszélgetés, személyes közlés, Olaszország, Bologna. Fordította és aktualizálta: Kállay Mikós.

AMRANI JOUTEI, K., GLORIES, Y. (1995): Tanins et anthocyanes: Localisation dans les baies de raisin et mode d'extraction. Rev. Fr. Oenol. 153:28-31.

BALGA I., VILLANGÓ, SZ. (2012): Nagy minőségű vörösborok. Agrofórum, 23(2):22-24.

BARBE J.C., REVEL G., PERELLO M.C., LONVAUD-FUNEL A., BERTRAND A. (2001): REv. Fr. Oenol. 190:16.

BARÓCSI Z. (2006): A rügy- és fürtterhelés hatása az Egri Bikavért adó szőlőfajták vegetatív és generatív teljesítményére. Doktori Értekezés, Budapest, Budapesti Corvinus Egyetem.

BARÓCSI Z. (2003): Milyen fajtákból készül az Egri Bikavér? Egri Bikavér Bulletin, Egri Szölészeti Borászati Szolgáltató Kht. Eger, pp4-5.

BATE-SMITH, E.C. (1973): Haemanalysis of tannins: The concept of relative astringency. Phytochemistry. 12(4):907-912. http://dx.doi.org/10.1016/0031-9422(73)80701-0.

BATE-SMITH, E.C., SWAIN, T. (1965): Recent developments in the chemotaxonomy of flavonoid compounds. Lloydia. 28:313-331.

BÉNYEI F., LŐRINCZ A. (2005): Borszőlőfajták, csemegeszőlő-fajták és alanyok. Fajtaismeret és fajtahasználat. Budapest, Mezőgazda Kiadó.

BÉNYEI F., LŐRINCZ A., SZ. NAGY L. (1999): Szőlőtermesztés. Budapest, Mezőgazda Kiadó.

BERTELLI, A.A.E., MANNARI, C., SANTI, S., FILIPPI, C., MIGLIORI, M., GIOVANNINI, L. (2008): Immunomodulatory Activity of shikimic acid and quercitin in comparison with Oseltamivir (Tamiflu) in an In Vitro Model. Journal of Medical Virology. 80:741-745. http://dx.doi.org/10.1002/jmv.21072.

BRITO, P., ALMEIDA, L.M., DINIS, T.C. (2002): The interaction of resveratrol with ferrylmyoglobin and peroxynitrite; protection against LDL oxidation. Free Radic Res. 36(6):621-631. http://dx.doi.org/10.1080/10715760290029083.

CANALS, R., LAUDY, M.C., VALLS, J., CANALS, J.M., ZAMORA, F. (2005): Influence of ethanol concentration on the extraction of color and phenolic compounds from the skin and seeds of Tempranillo grapes at different stages of ripening. J. Agric. Food Chem. 53(10):4019-4025. http://dx.doi.org/10.1021/jf047872v.

CHATONNET, P.(1995): Influence des procédés de tonnelerie et des conditions d'élevage sur la composition et la qualité des vins élevés en fûts de chêne. Thèse de Doctorat, Université de Bordeaux 2, Bordeaux. 
CHEYNIER, V., BASIRE, N., RIGAUD, J. (1989a): Mechanism of trans-caffeoyltartaric acid and catechin oxidation in model solutions containing grape polyphenoloxidase. J. Agric. Food Chem. 37(4):1069-1071. http://dx.doi.org/10.1021/jf00088a055.

CHEYNIER, V., RIGAUd, J., SOUQUET, J.M., BARILlERE, J.M., MOUTOUNET, M. (1989b): Effect of pomace contact and hyperoxidation on the phenolic composition and quality of Grenache and Chardonnay wines. Am. J. Enol. Vitic. 40(1):36-42.

CHINAUD, N.- FERRARI, G. (1992): Le remintage par injection de gas en vinification. Revue Francaise d' Oenoligie. 138:13-18.

CHIRA, K., SCHMAUCH, G., SAUCIER, C., FABRE, S., TEISSEDRE, P.L. (2009): Grape variety effect on proanthocyanidin composition and sensory perception of skin and seed tannin extracts from bordeaux wine grapes (Cabernet Sauvignon and Merlot) for two consecutive vintages (2006 and 2007). J. Agric. Food Chem. 57(2):545-553. http://dx.doi.org/10.1021/jf802301g.

CHIRA, K., SUH, J.H., SAUCIER, C., TEISSEDRE, P.L. (2008): Les polyphénols du raisin. Phytotherapie, 6(2):75-82. http://dx.doi.org/10.1007/s10298-008-0293-3.

CSEPREGI P. (1993): Szőlőtermesztés III. Fajtaismeret. Egyetemi jegyzet. Budapest, Kertészeti és Élelmiszer-ipari Egyetem.

CSEPREGI P., ZILAI J. (1989): Szőlőfajta-ismeret és használat. Budapest, Mezőgazdasági Kiadó.

CSOMÓS E; SIMON-SARKADI L. (2002): Determination of biologically active compounds in Hungarian wines. Periodica Polytechnica Chemical Engineering. 46(1-2):73-81.

DALLAS, C., RICARDO-DA-SILVA, J.M., LAUREANO, O. (1996): Products formed in model wine solutions involving anthocyanins, procyanidin B2, and acetaldehyde. J. Agric. Food Chem. 44(8):2402-2407. http://dx.doi.org/10.1021/jf940433j.

DANG Z.C., LOWIK C. (2005): Dose-dependent effects of phytoestrogens on bone. Trends Endocrinol Metab. 6:207-13. http://dx.doi.org/10.1016/j.tem.2005.05.001.

DARNÉ, G. (1991): Recherces sur la composition en anthocyanes des grappes et des feuilles de vigne. Thèse de Doctorat, Université de Bordeaux 2, Bordeaux.

DAWES, C.; WOOD, C.M. (1973): The contribution of the oral minor mucous gland secretions to the volume of whole saliva in man. Arch. Oral Biol. 18:337-342. http://dx.doi.org/10.1016/0003-9969(73)90156-8.

DE ANDRÉS-DE PRADO, R., YUSTE-ROJAS, M., SORT, X., ANDRES-LACUEVA, C., TORRES, M., LAMUELA-RAVENTOS, R.M. (2007): Effect of soil type on wines produced from Vitis vinifera L. Cv. Grenache in commercial vineyards. J. Agric. Food Chem. 55(3):779786. http://dx.doi.org/10.1021/jf062446q.

DELGADO, R., MARTÍN, P., DEL ÁLAMO, M., GONZÁLEZ, M.R. (2004): Changes in the phenolic composition of grape berries during ripening in relation to vineyard nitrogen and potassium fertilisation rates. J. Sci. Food Agric. 84(7):623-630. http://dx.doi.org/10.1002/jsfa.1685.

DELOIRE A. (2010): Másképpen a szőlőtermesztésről, avagy a borminőség alakítása a világpiaci trendjeinek megfelelően. XI. Szőlészeti és Borászati Konferencia, Eger. 
DIÓFÁSI L. (1985): A minőségi borszőlőtermesztés tudományos alapjai. Budapest, Mezőgazdasági Kiadó.

DOWNEY, M.O., HARVEY, J.S., ROBINSON, S.P. (2003): Analysis of tannins in seeds and skins of Shiraz grapes throughout berry development. Aust. J. Grape Wine Res. 9(1):15-27. http://dx.doi.org/10.1111/j.1755-0238.2003.tb00228.x.

EPERJESI I., KÁLLAY M., MAGYAR I. (1998): Borászat. Mezőgazda Kiadó, Budapest.

FANG, F., LI, J.M., ZHANG, P., TANG, K., WANG, W., PAN, Q.H., HUANG, W.D. (2008): Effects of grape variety, harvest date, fermentation vessel and wine aging on flavonoid concentration in red wines. Food Res. Int. 41(1):53-60. http://dx.doi.org/10.1016/j.foodres.2007.09.004.

FERENCZI S., TUZSON I. (1958): Időjárási tényezők befolyása a borok összetételére. Szőlészeti Kutató Intézet Évkönyve. pp97-132.

FERRARINI, R., ZIRONI, R., CELOTTI, E., ANDREA, E. (2001): Ruolo dell' ossigeno nei processi di vinificazione ed affinamento dei vini. L'Enologico. XXXVII(11):77-86.

FLANZY, M., AUBERT, S., MARINOS, M. (1969): New technique for determination of leucoanthocyaninc tannis. Applications. Ann. Technol. Agric. 18:327-328.

FONG, R.A., KEPNER, R.E., WEBB, A.D. (1971): Acetic-acid-acylated anthocyanin pigments in the grape skins of a number of varieties of Vitis vinifera. Am. J. Enol. Vitic. 22(3):150-155.

FULDA S., DEBATIN K.M. (2006): Resveratrol modulation of signal transduction in apoptosis and cell survival: a mini-review. Cancer Detect Prev. 30(3):217-223.

GÁL L. (2006): Az Egri Bikavér minőségfejlesztésének lehetőségei. Doktori Értekezés, Budapest, Budapesti Corvinus Egyetem.

GALVIN, C. (1993): Etude de certaines réactions de dégradation des anthocyanes et de leur condensation avec les flavanols; Conséquences sur la couleur des vins. Thése de Doctorat, Université de Bordeaux 2.

GLORIES, Y. (1978): La matière colorante du vin rouge Thèse d'Etat, Université de Bordeaux 2, Bordeaux.

GOLDFINGER T.M. (2003): Beyond the French paradox: The impact of moderate beverage alcohol and wine consumption in the prevention of cardiovascular disease. Cardiology Clinics. 21:449-457. http://dx.doi.org/10.1016/s0733-8651(03)00081-x.

GUEBAILIA, H.A., CHIRA, K., RICHARD, T., MABROUK, T., FURIGA, A., VITRAC, X., MONTI, J.P.;,DELAUNAY, J.C., MERILLON, J.M. (2006): Hopeaphenol: the first resveratrol tetramer in wines from North Africa. J. Agric. Food Chem. 54(25):9559-9564. http://dx.doi.org/10.1021/jf062024g.

HALLS C, YU O. (2008): Potential for metabolic engineering of resveratrol biosynthesis. Trends Biotechnol. 26:77-81. http://dx.doi.org/10.1016/j.tibtech.2007.11.002.

HRAZDINA, G. (1970): Oxidation of the anthocyanidin-3,5-diglucosides with $\mathrm{H}_{2} \mathrm{O}_{2}$ : the structure of malvone. Phytochemistry. 9:1647-1652. http://dx.doi.org/10.1016/s00319422(00)85290-5. 
HUMPHREY, S.P.; WILLIAMSON, R.T. (2001): A review of saliva: normal composition, flow, and function J. Prost. Dent. 85(2):162-169. http://dx.doi.org/10.1067/mpr.2001.113778.

JACKSON, R.S. (2000): Wine Scienece: Principles, Practice, Perception. San Diego, CA, $2^{\text {nd }}$ ed. Academic Press.

JANKY F., KÁLLAY M. (2001): Összefoglaló jelentés a Szőlőskert Borászati és Hűtőipari RT Nagyréde számára. Budapest, Szent István Egyetem.

JEANDET, P., BESSIS, R., GAUTHERON, B. (1991): The production of resveratrol (3,5,4'trihydroxystilbene) by grape berries in different developmental stages. Am. J. Enol. Vitic. 42(1):41-46.

KALATHENOS P., SUTHERLAND J.P., ROBERTS T.A. (1995): Resistance of some wine spoilage yeasts to combinations of ethanol and acids present in wine. Journal Appl. Bacteriol. 78:245-250. http://dx.doi.org/10.1111/j.1365-2672.1995.tb05023.x.

KÁLLAY M. (1995): A jellemző magyar borszőlőfajták, illetve azok borai polifenol összetételének vizsgálata, különös tekintettel a procianidin-koncentrációra összefüggésben a bor élettani hatásával. Zárójelentés, OTKA T 5212 sz. téma pp24-25.

KÁLLAY M. (2010): Borászati Kémia, Mezőgazda Kiadó, Budapest.

KÁLLAY M., TÖRÖK, Z. (1997): Determination of resveratrol isomers in Hungarian wines. Kertészeti Tudomány. 29:78-82.

KOUNDOURAS, S., MARINOS, V., GKOULIOTI, A., KOTSERIDIS, Y., VAN LEEUWEN, C. (2006): Influence of vineyard location and vine water status on fruit maturation of nonirrigated cv. Agiorgitiko (Vitis vinifera L.). Effects on wine phenolic and aroma components. J. Agric. Food Chem. 54(14):5077-5086. http://dx.doi.org/10.1021/jf0605446.

KOZMA P. (1991): A szőlő és termesztése I. Budapest, Akadémia Kiadó.

KOZMA P. (2001): A szőlő és termesztése. Budapest, Akadémia Kiadó.

LEONE, A.M., LA NOTTE, E., GAMBACORTA, G. (1984): Gli antociani nelle fasi di macerazione e di elaborazione del vino. L'influenza della tecnica diffusiva sulla Ioro estrazione. Vignevini. 4:17-25.

LOPES, P. (2005): L'etude des phenomenes oxydatifs pendant le vieillissement des vins en bouteille. Role de l'obturateur. Thèse de Doctorat, Université Bordeaux 2, Bordeaux.

LÖRINCZ GY. (1997): Újtípusú vörösborok készítése szénsavatmoszférában. Doktori Értekezés, Budapest, Szent István Egyetem.

MAGYAR, I. (2010): Borászati mikrobiológia, Mezőgazda Kiadó, Budapest.

MATTIVI, F., NICOLINI, G. (1993): Influenza della technica di vinificazione sul contenuto di resveratrolo dei vini. L'Enotechnico. (7-8):81-88.

MAYÉN, M., MÉRIDA, J., MEDINA, M. (1995): Flavonoid and non-flavonoid compounds during fermentation and post-fermentation standing of must from Cabernet Sauvignon and Tempranillo grapes. Am. J. Food Chem. 47(10):4009-4017.

MAZZA, G., FRANCIS, F.J. (1995): Anthocyanins in grapes and grape product. Critical Reviews in Food Science and Nutrition. 35(4):341-371. http://dx.doi.org/10.1080/10408399509527704 
MESCHTER, E.E. (1953): Fruit color loss, effects of carbohydrates and other factors on strawberry products J. Agric. Food Chem. 1(8):574-579. http://dx.doi.org/10.1021/jf60008a007

MESE, H., MATSUO, R. (2007): Salivary secretion, taste and hyposalivation. Journal of Oral Rehabilitation. 34:711-723. http://dx.doi.org/10.1111/j.1365-2842.2007.01794.x

MIZUTANI K., IKEADA K., KAWAI Y., YAMARI Y. (2000): Resveratrol attenuates ovariectomy-induced hypertension and bone loss in stroke-prone spontaneously hypertensive rats. J Nutr Sci Vitaminol. Tokyo, 46(2):78-83. http://dx.doi.org/10.3177/jnsv.46.78

MORI, K., SUGAYA, S., GEMMA, H. (2005): Decreased anthocyanin biosynthesis in grape berries grown under elevated night temperature condition. Sci. Hortic. 105(3):319-330.

MORI, K.; GOTO-YAMAMOTO, N., KITAYAMA, M., HASHIZUME, K. (2007): Loss of anthocyanins in redwine grape under high temperature. J. Exper. Bot. 58(8):1935-1945. http://dx.doi.org/10.1093/jxb/erm055

ORTEGA-REGULES, A., ROMERO-CASCALES, I., ROS-GARCÍA, J.M., LÓPEZ-ROCA, J.M., GÓMEZ- PLAZA, E. (2006): A first approach towards the relationship between grape skin cell-wall composition and anthocyanin extractability. Anal. Chim. Acta 563(1-2):26-32. http://dx.doi.org/10.1016/j.aca.2005.12.024

OSZMIANSKI, J., ROMEYER, F.M., SAPIS, J.C., MACHEIX, J.J. (1986): Grapes seed phenolics: Extraction as affected by some conditions occurring during wine processing. Am. J. Enol. Vitic. 37(1):7-12.

PALIYATH, G., MURR D.P. (2006): Biochemistry of fruits. In: Y.H. HUI (ed): Food bichemistry and food processing. Wiley-Blackwell, NJ, USA. http://dx.doi.org/10.1002/9780470277577.ch21

PAN Q.H., WANG L, LI J.M. (2009): Amounts and subcellular localization of stilbene synthase in response of grape berries to UV irradiation. Plant Sci. 176:360-66. http://dx.doi.org/10.1016/j.plantsci.2008.12.004

PASTEUR, L. (1866): Études sur le Vin. Tanulmány, Franciaország, Lille, Université de Lille.

PÁSTI GY. (2002): Kékszőlő-feldolgozási technológiák elemzése a minőségi vörösbor készítés függvényében. Doktori Értekezés, Budapest, Szent István Egyetem.

PÁSTI GY., ÚJVÁRI T., KORÁNY K. (1992): A borok barrique érlelése. Kertészeti Tudomány. 26(1):43-46.

PEREZ R.M., ZAVALA S., PEREZ G. (1998): Antidiabetic effect of compounds isolated from plants. Phytomedicine. 5(1):55-75. http://dx.doi.org/10.1016/s0944-7113(98)80060-3

PÉREZ-MAGARIÑO, S., GONZÁLEZ-SAN, J.M.L. (2006): Polyphenols and colour variability of red wines made from grapes harvested at different ripeness grade. Food Chem. 96(2):197208. http://dx.doi.org/10.1016/j.foodchem.2005.02.021

PERI, C., POMPEI, C. (1971): An assay of differnce phenolic fractions in Wine. Am. J. Enol. and Vitic. 22:55-58.

PEYNAUD E., BLOUIN J. (1996): Le Goût du vin. Dunod, Paris.

PEZET, R., CUENAT, P. (1996): Resveratrol in wine: Extraction from skin during fermentation and post-fermentation standing of must from Gamay grapes. Am. J. Enol. Vitic. 47(3):287-290. 
PIRIE, A., MULLINS, M.G. (1976): Changes in anthocyanin and phenolics content of grapevine leaf and fruit tissues treated with sucrose, nitrate, and abscisic acid. Plant Physiol. 58(4):468472. http://dx.doi.org/10.1104/pp.58.4.468

PIRIE, A., MULLINS, M.G. (1980): Concentration of phenolics in skin of grape berries during fruit tissues treated with sucrose, nitrate, and abscisic acid. Plant Physiol. 58:468-472.

PRASAD, K. N., YANG, B., DONG, X., JIANG, G., ZHANG, H., XIE, H., JIANG, Y. (2009): Flavonoid contents and antioxidant activities from Cinnamomum species Innovat. Food Sci. Emerg.Tech. 10(4):627-632. http://dx.doi.org/10.1016/j.ifset.2009.05.009

READ, M.A. (1995): Flavonoids: Naturally occurring Anti-Inflammatory Agents. American Journal of Pathology. 147(2):235-237.

REBELEIN, H. (1965): Beitrag zur Bestimmung des Catechingehaltes in Wein. Dtsch. LebensmRundschau, 61:182-183.

RIBEIRO DE LIMA, M.T., WAFFO-TEGUO, P., TEISSEDRE, P.L., PUJOLAS, A., VERCAUTEREN, J., CABANIS, J.C., MERILLON, J.M. (1999): Determination of stilbenes (trans-astringin, cis- and transpiceid, and cis- and trans-resveratrol) in Portuguese wines. J. Agric. Food Chem. 47(7):2666-2670. http://dx.doi.org/10.1021/jf9900884

RIBÉREAU-GAYON J., PEYNAUD E., RIBÉREAU-GAYON P., SUDRAUD P. (1982): Analyse et Contrôle des Vins. Sciences et Techniques du Vin. Vol. I. $2^{\text {nd }}$ edn. Dunod, Paris.

RIBÉREAU-GAYON, J. (1963): Les acides phénols de Vitis vinifera C. R. Académie des Sciences, 256:4108-4111.

RIBÉREAU-GAYON, P., STONESTREET, E. (1966): Le dosage des tannins du vin rouge et la détermination de leur structure. Chimie Analytique, 48:188-196.

RIBÉREAU-GAYON, P., GLORIES, Y., MAUJEAN, A., DUBOURDIEU, D. (1998): In Traité d'oenologie 2.Chimie du vin Stabilisation et traitements, Paris, Ed. Dunod.

RIBÉREAU-GAYON, P., GLORIES, Y., MAUJEAN, A., DUBOURDIEU, D. (2006): Handbook of Oenology, Volume 2; The Chemistry of Stabilization and Treatments, p5.

RÍO-SEGADE, S., ROLLE, L., GERBI, V., ORRIOLS, I. (2008): Phenolic ripeness assessment of grape skin by texture analysis. Journal of Food Composition and Analysis. 21(8):644-649. http://dx.doi.org/10.1016/j.jfca.2008.06.003

RIOU, V., VERNHET, A., DOCO, T., MOUTOUNET, M. (2002): Aggregation of grape seed tannins in model wine: effect of wine polysaccharides. Food Hydroc. 16:17-23. http://dx.doi.org/10.1016/s0268-005x(01)00034-0

RIVIERE C, PAPASTAMOULIS Y, FORTIN PY, DELCHIER N, ANDRIAMANARIVO S. (2010): New stilbene dimers against amyloid fibril formation. Bioorg Med Chem Lett. 20:34413443. http://dx.doi.org/10.1016/j.bmcl.2009.09.074

ROBICHAUD, J.L., NOBLE, A.C. (1990): Astrigency and bitterness of selected phenolics in wine. J. Sci. Food Agric. 53:343-353. http://dx.doi.org/10.1002/jsfa.2740530307

ROBY, G., HARBERTSON, J.F., ADAMS, D.A., MATTHEWS, M.A. (2004): Berry size and vine water deficits as factors in winegrape composition: Anthocyanins and tannins. Aust. J. Grape Wine Res. 10(2):100-107. http://dx.doi.org/10.1111/j.1755-0238.2004.tb00012.x 
ROLLE, L., TORCHIO, F., ZEPPA, G., GERBI, V. (2008): Anthocyanin extractability assessment of grape skins by texture analysis. International Journal of Vine and Wine Sciences. 42(3):157-162.

RONALD S.J. (2002): Wine tasting: A Professional Handbook. Chemical compounds involved. pp99-103.

SAUCIER C., ROUX. D. (2000): Interactions tanins-colloïdes: nouvelles avancées concernant la notion de bons et de mauvais tanins. Revue des Oenologues. 94:9-10.

SINGLETON, V.L., ESAU, O. (1969): Phenolic Substances in grapes and Wine, and their Significance 31, New York.

SINGLETON, V.L.; ESAU, P. (1969): Phenolic substances in grapes and wine, and their significance Adv. Food Res. Suppl. 1-261, 282.

SLINKARD, K., SINGLETON, V.L. (1977): Total phenol analysis: Automation and comparison with manual methods. American Journal of Enology and Viticulture, 28:49-55.

STEFANOVICS P., FILEP GY., FÜLEKI GY. (2010): Talajtan. Budapest, Mezőgazda Kiadó.

SUDRAUD, P. (1958): Interpétation des courbes d'absorption de vins rouges. Annals of Technology Agriculture, 7:203-208.

SUN, B.S., PINOT, T., LEANDRO, M.C., RICARDO-DA-SILVA, J.M., SPRANGER, M.I. (1999): Transfer of catechins and proanthocyanidins from solid parts of the grape cluster into wine. Am. J. Enol. Vitic. 50(2):179-184.

SZ. NAGY L. (1986): Szőlőtermesztés. Egyetemi jegyzet. Budapest, Kertészeti és Élelmiszeripari Egyetem.

TABACHNICK, B.G., FIDELL, L.S. (2013): Using Multivariate Statistics, $6^{\text {th }}$ ed. Boston: Allyn and Bacon.

TIMBERLAKE, C.F., BRIDLE, P. (1976): Interactions between anthocyanins, phenolic compounds, and acetaldehyde and their significance in red wines. Am. J. Enol. Vitic. 27(3)97105.

VASSANELLI, C. (1992): Studio Chimico Enologico, Verona.

VÈRETTE, E.; NOBLE, A.C.; SOMERS, T.C. (1988): Hydroxycinnamates of Vitis vinifera: Sensory assessment in relation to bitterness in white wines J. Sc. Food Agric. 45(3):267-272. http://dx.doi.org/10.1002/jsfa.2740450310

VITRAC, X., BORNET, A., VANDERLINDE, R., VALLS, J., RICHARD, T., DELAUNAY, J.C., MERILLON, J.M., TEISSÈDRE, P.L. (2005): Determination of stilbenes ( $\delta$-viniferin, trans-astringin, trans-piceid, cis and trans-resveratrol, $\varepsilon$-viniferin) in Brazilian wines. J. Agric. Food Chem. 53(14):5664-5669. http://dx.doi.org/10.1021/jf050122g

VIVAS, N. (1993): Les conditions d'élaboration des vins rouges destinés á n élevage en barrique. Revue des Oenologues. 68:27-33.

VIVAS DE GAULEJAC, N., VIVAS, N., ABSALON, C., NONIER, M.F. (2001): Identification of procyanidin A2 in grape and wine of Vitis vinifera L. CV. Merlot noir and Cabernet sauvignon. J. Int. Sci. Vigne Vin 35(1):51-56. 
WANG, C.Y., CHEN, C.T., WANG, S.Y. (2009): Changes of flavonoid content and antioxidant capacity in blueberries after illumination with UV-C. Food Chem. 117(3):426-431. http://dx.doi.org/10.1016/j.foodchem.2009.04.037

WEATHERELL, J.A.; STRONG, M.; ROBINSON, C.; NATTRESS, B.R.; NAKAGAKI, H.; MAIN, D.M. (1992): Determination of volumes of fluid in the mouth by fluoride dilution Caries res. 26:94-97. http://dx.doi.org/10.1159/000261491

WIGHTMAN, J.D., PRICE, S.F., WATSON, B.T., WROLSTAD, R.E. (1997): Some effects of processing enzymes on anthocyanins and phenolics in Pinot noir and Cabernet Sauvignon wines. Am. J. Enol. Vitic. 48(1):39-48.

WILLIAMSON G., MANACH C. (2005): Bioavailability and bioefficacy of polyphenols in humans. II. Review of 93 intervention studies ${ }^{1-4}$. Am. J. Clin. Nutr. 5(81):243-255.

WU, A.M.; CSAKO, G.; HERP, A. (1994): Structure, biosynthesis, and function of salivary mucins Mol. Cell. Biochem. 137(1):39-55. http://dx.doi.org/10.1007/bf00926038

YAMAMURA S, OZAWA K, OHTANI K, KASAI R, YAMASAKI K (1998): Antihistaminic flavones and aliphatic glycosides from Mentha spicata. Phytochemistry. 48:131-136. http://dx.doi.org/10.1016/s0031-9422(97)01112-6

YANG, J., MARTINSON, T.E., LIU, R.H. (2009): Phytochemical profiles and antioxidant activities of wine grapes. Food Chem. 116:332-339. http://dx.doi.org/10.1016/j.foodchem.2009.02.021

1995. évi XC. törvény: Magyar Élelmiszertörvény

http://boraszat.kormany.hu/eredetvedelem

http://boraszat.kormany.hu/eger

http://tudasbazis.sulinet.hu/hu/termeszettudomanyok/biologia/biologia-11-evfolyam/a-szaglases-az-izerzekeles/az-izerzekeles

ISO 8402-1994: Quality management and quality assurance.

MSZ 14849-1979: Borok pH-jának meghatározása.

MSZ 9458-1972: Borvizsgálatok. Szesztartalom meghatározás lepárálással.

MSZ 9463-1985: Borok extrakttartalmának meghatározása piknométeres módszerrel.

MSZ 9472-1986: Borok összes savtartalmának meghatározása.

MSZ 9479-1980: Borok cukortartalmának meghatározása Rebelein-módszerrel. 


\section{2. ÁBRAJEGYZÉK}

1. ábra: $\mathrm{L}(+)$-borkősav és a $\mathrm{D}(-)$-borkősav szerkezeti képlete

2. ábra: Almasav szerkezeti képlete

3. ábra: $\mathrm{D}(+)$-glükóz és $\mathrm{D}(-)$-fruktóz

4. ábra: Fenolsavak kémiai összetétele a szőlőben és a borban

5. ábra: 3,5,4’-trihidroxi sztilbén

6. ábra: Flavonoidok alapszerkezete

7. ábra: Katechin kémiai szerkezete

8. ábra: Flavandiol-3,4, kémiai alapváza

9. ábra: Procianidin dimer kémiai struktúrája

10. ábra: Antocianin kémiai szerkezete

11.ábra: A szőlő érési jellegzetességei

12. ábra: Borkészítés folyamatábrája (Jackson, 2000)

13. ábra: Különböző ízekre érzékeny ízlelőbimbók elhelyezkedése a nyelven

14. ábra: Kékfrankos - SZBKI (Fotó: Villangó Szabolcs)

15. ábra: Szőlőhéjextraktumok vizsgálatainak eredményei a 2007-es évjáratban

16. ábra: Szőlőhéjextraktumok transz-piceid vizsgálatainak eredményei a 2007-es évjáratban

17. ábra: Szőlőhéjextraktumok vizsgálatának eredményei a 2008-as évjáratban

18. ábra: Szőlőhéjextraktumok cisz-piceid vizsgálatának ereményei a 2008-as évjáratban

19. ábra: Szőlőhéjextraktumok vizsgálatának eredményei a 2009-es évjáratban

20. ábra: Szőlőhéjextraktumok transz-piceid, cisz- és transz-rezveratrol vizsgálatainak eredményei a 2009-es évjáratban

21. ábra: Blauburger fenolos vegyületeinek eloszlása a fürtön belül a 2007-es évjáratban 22. ábra: Transz-piceid fürtön belüli eloszlása a Blauburger szőlőfajtában, a 2007-es évjáratban 
23. ábra: Kékfrankos szőlőfajta finomösszetételének eloszlás a fürtön belül a 2007-es évjáratban

24. ábra: Kékfrankos szőlőfajta transz-piceid tartalma a fürtön belül a 2007-es évjáratban

25. ábra: Zweigelt szőlőfajta fenolos összetétele a 2007-es évjáratban

26. ábra: Transz-piceid fürtön belüli eloszlása a Zweigelt szőlőfajtában, a 2007-es évjáratban

27. ábra: Pinot noir szőlőfajta fenolos vegyületeinek eloszlása a fürtön belül a 2008-as évjáratban

28. ábra: Pinot noir cisz-piceid tartalma a fürtön belül a 2008-as évjáratban

29. ábra: Merlot szőlőfajta héjában található fenolos vegyületek a 2008-as évjáratban

30.ábra: Cisz-piceid alakulása a Merlot szőlőfajtában a 2008-as évjáratban

31. ábra: Cabernet franc fenolos komponensei a fürtön belül a 2008-as évjáratban

32.ábra: Cisz-piceid alakulása a Cabernet franc szőlőfürtben a 2008-as évjáratban

33. ábra: Turán szőlőfajta fürtön belüli fenolos vegyületeinek eloszlása a 2009-es évjáratban

34. ábra: Sztilbénvegyületek eloszlása a Turán szőlőfajta fürtjén belül a 2009-es évjáratban

35. ábra: Bíbor kadarka fenolos összetevőinek alakulása a fürtön belül a 2009-es évjáratban

36. ábra: Rezveratrol vegyületek eloszlása a Bíbor kadarka szőlőfajta fürtjén belül a 2009-es évjáratban

37. ábra: Syrah szőlőfajta fenolos vegyületeinek eloszlása a fürtön belül a 2009-es évjáratban

38. ábra: Syrah szőlőfajta rezveratroltartalmának eloszlása a fürtön belül a 2009-es évjáratban

39. ábra: A borok antocianin-tartalma (3 évjárat átlaga)

40. ábra: A borok összespolifenol-tartalma (3 év átlaga)

41. ábra: A borok katechintartalma (3 év átlaga)

42. ábra: A borok leukoantocianin-tartalma (3 év átlaga)

43. ábra: A borok színintenzitása (3 év átlaga)

44. ábra: A borok színárnyalat (3 év átlaga)

45. ábra: A borok transz-piceid tartalma (3év átlaga) 
46.ábra: A borok cisz-piceid tartalma (3 év átlaga)

47.ábra: A borok transz-rezveratrol tartalma (3 év átlaga)

48.ábra: A borok cisz-rezveratrol tartalma (3 év átlaga)

49.ábra: 2007-es Egri Bikavér profildiagramja

50.ábra: 2008-as Egri Bikavér profildiagramja

51.ábra: 2009-es Egri Bikavér profildiagramja

1. táblázat: Fenolos vegyületek csoportosítása (Peri és Pompei, 1971)

2. táblázat: Classicus Egri Bikavér Analitikai paraméterei (Termékleírás)

3. táblázat: 2007-es évjárat klimatikus jellemzése

4. táblázat: 2008-as évjárat klimatikus jellemzői

5. táblázat: 2009-es évjárat klimatikus jellemzői

6. táblázat: Mustok rutinanalitikai eredményei a 2007-es évjáratban

7. táblázat: Mustok rutinanalitikai eredményei a 2008-as évjáratban

8. táblázat: Mustok rutinanalitikai eredményei a 2009-es évjáratban

9. táblázat: 2007-es évjárat borainak alapanalitikai összetétele

10. táblázat: 2008-as évjárat borainak alapanalitikai összetétele

11. táblázat: 2009-es évjárat borainak alapanalitikai összetétele

12. táblázat: A 2007-es évjáratból származó borok fenolos összetevőinek vizsgálati értékei

13. táblázat: A 2008-as évjáratból származó borok fenolos összetevőinek vizsgálati értékei

14. táblázat: A 2009-es évjáratból származó borok fenolos összetevőinek vizsgálati értékei

15. táblázat: 2007-es újborok érzékszervi bírálati eredményei

16. táblázat: 2007-es óborok érzékszervi bírálati eredményei

17. táblázat: 2008-as újborok érzékszervi bírálati eredményei 
18. táblázat: 2008-as óborok érzékszervi bírálati eredményei

19. táblázat: 2009-es újborok érzékszervi bírálati eredményei

20. táblázat: 2009-es óborok érzékszervi bírálati eredményei 


\title{
13. MELLÉKLETEK
}

\section{M1. 102/2009. (VIII. 5.) FVM rendelet}

\section{Az Egri borvidék védett eredetü borairól}

A szőlőtermesztésről és a borgazdálkodásról szóló 2004. évi XVIII. törvény 57. § (1) bekezdés i) és t) pontjában kapott felhatalmazás alapján - a földmüvelésügyi és vidékfejlesztési miniszter feladat- és hatásköréről szóló 162/2006. (VII. 28.) Korm. rendelet 1. $\S$ a) pontjában meghatározott feladatkörben eljárva - a következőket rendelem el:

\section{Az Egri borvidék védett eredetü borainak listája}

\section{1. $\S$}

(1) Az Egri borvidék e rendeletben meghatározott védett eredetü borai csak védett eredetű borként és a rendeletben meghatározott feltételekkel hozhatók forgalomba.

(2) Az Egri borvidék védett eredetü borai:

a) „Debrői Hárslevelü”,

b) „Eger”,

c) „Egerszóláti Olaszrizling”.

(3) A (2) bekezdés a)-c) pontjaiban felsorolt bormegnevezések önálló eredetmegjelölések.

(4) Az Egri borvidék védett eredetủ borainak klasszifikációs szintjei:

a) védett eredetü klasszikus bor,

b) védett eredetü superior bor.

\author{
I. Fejezet \\ AZ EGRI BORVIDÉK VÉDETT EREDETÜ BORAINAK SZAKMAI \\ SZABÁLYAI \\ ÁLTALÁNOS SZABÁLYOK
}

Szölötermesztés

2.

(1) Az e rendelet hatálybalépésekor meglévő szőlőültetvényen termett szőlőből a térállástól és a müvelésmódtól függetlenül bármely, az 1. §-ban meghatározott bor előállítható, ha az ültetvény tőkehiányát és fajtaidegen tőkeállományát felmérték, a tőkehiány mértéke nem haladja meg a telepítéskori tőkeszám 10\%-át és ezt a hegyközségi nyilvántartásban rögzítik. A hegyközségek hegybírói felmérést kötelesek évente elvégezni. Ha a felmérés azt állapítja meg, hogy a tőkehiány nagyobb mértékü a nyilvántartásban rögzítettnél, a termelő védett eredetü borra vonatkozó származási bizonyítványt nem kaphat.

(2) Védett eredetű klasszikus bor előállítására alkalmas új ültetvény létesítésének szakmai követelményei a következők:

a) hektáronkénti 3700 feletti tőkeszám,

b) legalább 0,8 méteres tőketávolság,

c) alacsony kordon, középmagas kordon, ernyő vagy más alacsony tőkeformának megfelelő művelésmód alkalmazása.

(3) Védett eredetű superior bor előállítására alkalmas új ültetvény létesítésének szakmai 
követelményei a következők:

a) hektáronkénti 4000 feletti tőkeszám,

b) legalább 0,8 méteres tőketávolság,

c) Guyot, középmagas kordon, valamint ezeknél alacsonyabb tőke müvelésmódok

alkalmazása.

\section{Töketerhelés, termésmennyiség}

\section{3. $\S$}

(1) Az Egri borvidék védett eredetü borai termelése esetén a metszéssel kialakított tőketerhelés legfeljebb 6 rügy/m2 lehet.

(2)Aszőlő termesztésekor a müvelésmódoknak és a fajtáknak megfelelő tőketerhelést kell alkalmazni.

(3) A hektáronkénti termésátlag

a) védett eredetü klasszikus borok esetén nem haladhatja meg a 90 hektolitert,

b) védett eredetű superior borok esetén nem haladhatja meg a 60 hektolitert.

\section{A szölö minöségére vonatkozó általános szabályok}

\section{4. $\S$}

Az Egri borvidék bármely védett eredetű borának előállításához szüretelt szőlő származási bizonyítványa csak a hegyközség által meghatározott szüret kezdési időpontja után, helyszíni szemle alapján adható ki. A szőlőfürtnek, épnek, egészségesnek és a fajtára jellemzőnek kell lennie. A szüret kezdési időpontját a szőlőültetvény fekvése szerint illetékes hegyközség határozza meg.

\section{Szölöfeldolgozás és borászati technológia}

\section{5.}

(1) Védett eredetű bor előállítása kizárólag a hegyközség által ellenőrzött, az Egri borvidéken pincekataszterben nyilvántartott pincészetekben történhet.

(2) Fehér- és rozéborok készítésének szakmai követelményei a következők:

a) a szőlőt a szüret napján fel kell dolgozni;

b) az egyes védett eredetü borok előállításához megfelelő szőlők feldolgozását a többi szőlő feldolgozásától elkülönítetten kell végezni;

c) a préselés csak szakaszos üzemü szőlőpréssel végezhető;

d) kötelezö a must tisztítása.

(3) Vörösborok készítésének szakmai követelményei a következők:

a) az egyes védett eredetű borok előállításához megfelelő minőségű szőlők feldolgozását a

többi szőlő feldolgozásától elkülönítetten kell végezni;

b) a szőlőcefrét héjon kell erjeszteni;

c) a préselés csak szakaszos üzemü szőlőpréssel végezhető.

\section{A bor minösítése}

\section{6. $\S$}

Az Egri Borvidék Borminősítő Bizottsága (a továbbiakban: borminősítő bizottság) végzi az 
Egri borvidék védett eredetü borainak érzékszervi bírálatát. Származási bizonyítvány csak a „megfelelt” minősítésü bortételre adható ki.

\section{Jelölés és forgalomba hozatal}

\section{7. $\S$}

(1) A címkén a bor minősítési kategóriáját a klasszifikációs kategória nevével kiegészítve kell jelölni, a következő módon:

a) védett eredetü klasszikus bor esetén: ,védett eredetü klasszikus bor”,

b) védett eredetü superior bor esetén: ,védett eredetü superior bor”.

(2) A védett eredetü superior borok csak üvegpalackba töltve hozhatók forgalomba.

(3) A bort kiszerelni csak a borászati hatóság által engedélyezett és az Egri Borvidék

Hegyközségi Tanácsa (a továbbiakban: EBHT) által nyilvántartásba vett palackozókban lehet. A palackozási kötelezettség nem vonatkozik az adott termőhelyen belül a termelö által, saját pincéjében, helyben fogyasztásra kerülö, saját termelésü boraira.

(4) A bort palackozásra a borvidékről kiszállítani a bor előállítójának előzetes bejelentése után az EBHT ellenőrzése mellett lehet. A bort a kiszállítás napjától számított 90 napon belül le kell palackozni, ellenkező esetben a bor az e rendeletben szabályozott védett eredetmegjelölések használatának jogát elveszíti. A borászati vállalkozás a kiszállított bor palackozási szándékáról 48 órával a palackozás megkezdése előtt köteles értesíteni a bor előállítása szerint illetékes hegyközség hegybíróját és az EBHT-t.

(5) A forgalomba kerülő védett eredetű egri borok palackján kötelező elhelyezni az EBHT által nyomdai úton elkészített, ,,védett eredetű bor” sorszámozott, hologrammal ellátott védjegyet (a továbbiakban: védjegy). A védjegyet a bor forgalomba hozatali engedély kiadását követően az EBHT bocsátja rendelkezésre térítés ellenében. A védjegy nyilvántartásáért az EBHT felel. A védjegy formája lehet szalag, illetve címke is. A védjegyet az 1. számú melléklet tartalmazza.

(6) Az Egri borvidék védett eredetű borainak címkéjén a jogszabályok elöírásain túlmenően fajtanév, vagy a bor színére utaló kifejezés abban az esetben tüntethető fel, amennyiben betütípusából, betüméretéből, vagy betüszínéből adódóan nem jelenik meg az eredetmegjelölésnél hangsúlyosabb módon.

\section{Egyes kifejezések feltüntetésének általános szabályai}

\section{8. $\S$}

(1) A „Superior” kifejezés feltüntetése csak a védett eredetü superior borok címkéjén lehetséges. A védett eredetü superior borok megnevezése kiegészül a „Superior” kifejezéssel, melyet a bor megnevezését követően, azzal azonos tipográfiával kell a címkén feltüntetni. $\mathrm{E}$ feltüntetési kötelezettség alól mentesülnek azok a borok, melyek címkéjén borvidéki dülő neve szerepel.

(2) Borvidéki dủlő nevének feltüntetése csak a védett eredetű superior borok címkéjén lehetséges abban az esetben, amennyiben a bor készítéséhez felhasznált szőlő 100\%-ban az adott dűlőből származik. A VINGIS szerint lehatárolt dűlő nevét a Földrajzinév-bizottság által meghatározott írásmóddal kell a címkén feltüntetni. Borvidéki dủlő nevének feltüntetése esetén a bor címkéjén a bor származása szerinti borvidéki település nevét is fel kell tüntetni. Borvidéki település feltüntetése a címkén más esetben nem lehetséges.

(3) A „Muskotály”, valamint a „Siller” kifejezés csak az „Eger” védett eredetü borok címkéjén a 9. §-ban meghatározott feltételek teljesítése esetén tüntethető fel.

(4) A „Bikavér” hagyományos kifejezés az „Eger” védett eredetü borok címkéjén a 10. §-ban meghatározott feltételek teljesítése esetén tüntethető fel. 


\section{Fejezet}

\section{AZ EGYES VÉDETT EREDETÜ BOROK TERMELÉSÉNEK, JELÖLÉSÉNEK ÉS FORGALOMBA HOZATALÁNAK KÜLÖNÖS SZABÁLYAI}

\section{Az „Eger” védett eredetü borokra vonatkozó különös szabályok}

\section{9. $\S$}

(1) A szőlő származási helye:

a) védett eredetủ klasszikus bort készíteni csak az Egri borvidék I. és II. termőhelyi kataszteri osztályában szereplő szőlöültetvényein termett szőlőkből lehet,

b) védett eredetü superior bort készíteni csak az Egri borvidék I. és II/1. termőhelyi kataszteri osztályában szereplő szőlöültetvényein termett szőlőkből lehet.

(2) Az alkalmazható szőlőfajták köre:

a) védett eredetü klasszikus bor előállítása chardonnay, cserszegi füszeres, hárslevelü, Irsai Olivér, királyleányka, leányka, olaszrizling, ottonel muskotály, pinot blanc, rajnai rizling, sárga muskotály, sauvignon blanc, szürkebarát, tramini, zenit, bíborkadarka, blauburger, cabernet franc, cabernet sauvignon, kadarka, kékfrankos, kékoportó, menoire, merlot, pinot noír, syrah, turán, vagy zweigelt szőlőfajtákból történhet;

b) védett eredetü superior bor előállítása chardonnay, hárslevelü, királyleányka, leányka, olaszrizling, pinot blanc, rajnai rizling, sauvignon blanc, szürkebarát, tramini, blauburger, cabernet franc, cabernet sauvignon, kadarka, kékfrankos, kékoportó, menoire, merlot, pinot noir, syrah, turán, vagy zweigelt szőlőfajtákból történhet.

(3) A bor előállításához felhasználható szőlő természetes alkoholtartalma:

a) védett eredetü klasszikus bor készítésekor

aa) cserszegi füszeres, Irsai Olivér, ottonel muskotály, és sárga muskotály fajták esetén legalább 9,87 térfogatszázalék,

ab) chardonnay, pinot blanc, sauvignon blanc, szürkebarát, tramini, zenit, cabernet franc, cabernet sauvignon, merlot, pinot noir, menoire és syrah fajták esetén legalább 12,08 térfogatszázalék, ac) minden más esetben legalább 10,60 térfogatszázalék;

b) védett eredetü superior bor készítésekor legalább 12,83 térfogatszázalék.

(4) A „Muskotály” kifejezés csak a cserszegi füszeres, Irsai Olivér, ottonel muskotály, vagy sárga muskotály szőlőfajták borainak házasításából készült védett eredetü klasszikus borok címkéjén tüntethető fel úgy, hogy betütípusából, betüméretéből, vagy betüszínéből adódóan ne jelenjen meg a védett eredetmegjelölésnél hangsúlyosabb módon.

(5) A „Siller” kifejezés az 5. § (3) bekezdésében foglaltak teljesítése esetén tüntethető fel a címkén úgy, hogy betűtípusából, betűméretéből, vagy betűszínéből adódóan ne jelenjen meg a védett eredetmegjelölésnél hangsúlyosabb módon.

(6) Amennyiben az „Eger” eredetmegjelölést fajtanév, a bor színére utaló, vagy a (4)-(6) bekezdésben meghatározott kifejezések követik, úgy az eredetmegjeölés írásmódja „Eger”-röl „Egri”-re változik.

\section{Egri Bikavér}

10. $\S$ 
(1) A „Bikavér” hagyományos kifejezést kizárólag

a) az e paragrafusban foglaltak teljesülése esetén és

b) az „Eger” eredetmegjelölés „Egri” alakját közvetlenül követően, azzal egy sorban és azonos tipográfiával lehet a címkén feltüntetni.

(2) A szőlő származási helye:

a) védett eredetü klasszikus bort készíteni csak Andornaktálya, Demjén, Eger, Egerbakta, Egerszalók, Egerszólát, Felsőtárkány, Kerecsend, Maklár, Nagytálya, Noszvaj, Novaj, Ostoros és Szomolya termőhelyi kataszterében szereplö, valamint Verpelét település a rendelet 2. számú mellékletében felsorolt szőlöültetvényein termett szőlőböl lehet, b) védett eredetü superior bort készíteni csak Andornaktálya, Demjén, Eger, Egerbakta, Egerszalók, Egerszólát, Felsőtárkány, Kerecsend, Maklár, Nagytálya, Noszvaj, Novaj, Ostoros és Szomolya termőhelyi kataszterében szereplő I. és II/1. osztályú, valamint Verpelét település a rendelet 2. számú mellékletében felsorolt szőlöültetvényein termett szőlöböl lehet.

(3) A felhasználható szőlőfajták: kékfrankos, kékoportó, kadarka, blauburger, zweigelt, cabernet franc, cabernet sauvignon, merlot, pinot noir, menoire, turán, bíborkadarka, syrah.

(4) A bor előállításához felhasználható szőlő természetes alkoholtartalma:

a) védett eredetü klasszikus bor készítésekor:

aa) kékfrankos, kékoportó, kadarka, blauburger, turán, bíborkadarka és zweigelt fajták esetén legalább 10,60 térfogatszázalék,

$a b$ ) cabernet franc, cabernet sauvignon, merlot, pinot noir, menoire és syrah fajták esetén legalább 12,08 térfogatszázalék;

b) védett eredetủ superior bor készítésekor legalább 12,83 térfogatszázalék.

(5) A bor készítésének szakmai követelményei:

a) védett eredetü klasszikus bor elöállítása esetén:

aa) az egyes védett eredetü borok előállításához megfelelő minőségű szőlők feldolgozását a többi szőlő feldolgozásától elkülönítetten kell végezni,

$a b)$ a szőlőcefrét legalább 8 napig héjon kell erjeszteni,

ac) a préselés csak szakaszos üzemü szőlőpréssel végezhető,

$a d)$ a bort legalább 6 hónapig fahordóban kell érlelni,

ae) a bor édesítése tilos;

$b$ ) védett eredetủ superior bor előállítása esetén az $a a$ ), $a c$ ) és az $a e$ ) pontban foglaltakon túlmenően:

ba) a szőlőcefrét legalább 14 napig héjon kell erjeszteni,

$b b)$ a bort legalább egy éven keresztül fahordóban kell érlelni,

bc) a bort a palackozást követően forgalomba hozatal előtt legalább 6 hónapig palackban kell érlelni.

(6) A bor készítésekor az alábbi házasítási szabályokat

kell követni:

a) védett eredetü klasszikus bor esetén:

aa) a bort legalább három szőlőfajta borának házasításával kell elkészíteni,

$a b)$ egy fajta borának aránya sem haladhatja meg az 50\%-ot,

ac) legalább három szőlőfajta bora arányának meg kell haladnia külön-külön az 5\%-ot,

ad) a fajták között a kékfrankos fajtának kell a legnagyobb arányt képviselni,

ae) a turán és bíborkadarka fajták borának aránya együttesen és külön-külön sem haladhatja

meg a $10 \%$-ot;

b) védett eredetü superior bor esetén:

ba) a bort legalább öt szőlőfajta borának házasításával kell elkészíteni,

bb) egy fajta borának aránya sem haladhatja meg az 30\%-ot,

$b c)$ legalább öt szőlőfajta bora arányának meg kell haladnia külön-külön az 5\%-ot,

$b d)$ a $b b)$ pont rendelkezése alól kivételt jelent a kékfrankos fajta bora, melynek használata legalább 30\%-os, de legfeljebb 50\%-os arányban kötelezö,

be) a turán fajta borának aránya nem haladhatja meg a 5\%-ot, 
bf) a cabernet franc és cabernet sauvignon fajták borának aránya együttesen sem haladhatja meg a $30 \%$-ot.

(7) A bor címkéjén tájékoztató feliratként csak azon fajták neve tüntethető fel, melyek legalább 5\%-ban kerültek a bor házasítása során felhasználásra.

(8) A bor csak üvegpalackban hozható forgalomba

a) védett eredetü klasszikus bor esetén leghamarabb a szüretet követő év november elseje után,

b) védett eredetü superior bor esetén leghamarabb a szüretet követő második év május elseje után.

\author{
III. Fejezet
}

\title{
AZ EGRI BORVIDÉK VÉDETT EREDETÜ BORAI NYILVÁNTARTÁSÁNAK ÉS ELLENÖRZÉSÉNEK SZABÁLYAI
}

\section{Bejelentések}

\section{3. $§$}

A szőlőtermelő és felvásárló a tevékenysége megkezdése évének április 30-áig köteles bejelenteni az EBHT részére, hogy védett eredetü bor előállításához kíván szőlőt termelni, illetve védett eredetű bort kíván előállítani. A bejelentett adatok változását az adott év április 30-áig kell bejelenteni. A bejelentés új hegyközségi tag esetén a tevékenység megkezdésekor kötelező.

\section{A származási bizonyítványok kiadása}

\section{4. $\S$}

A szőlő származási bizonyítványának kiadásánál a hegyközségek csak az EBHT által egységesen megállapított bélyegzőket használhatják.

\section{A mintavétel, palackozás, jelölés és készletezés szabályai}

\section{5. $\S$}

(1) A borvidék hegybírói a borvidék védett eredetü borainak védelme érdekében az illetékességi területükön lévő, valamint az általuk védett eredetü borra kiadott származási bizonyítvánnyal rendelkező borászati üzemeket rendszeresen ellenőrzik. Ennek során ellenőrzi a pincében lévő, forgalomba hozatali engedéllyel rendelkező, védett eredetü bor mennyiségét, valamint mintavétel, valamint és azt követően a borminősítő bizottság borbírálatának útján a bor minőségét.

(2) A mintavételt csak a hegybíró végezheti el a borvidéki rendtartás mellékletében szereplő mintavételi szabályzat szerint. A mintavételt követően a mintavevő az ellenmintát a helyszínen hagyja.

(3) A hegybíró a borászati üzem palackozási szándékának bejelentését követően köteles a helyszínen meggyőződni a bor forgalomba hozatali engedélyében foglaltak betartásáról.

(4) A bort palackozó borászati üzem alapvető kötelességei a következők:

a) betartja a müködési területe szerinti hegyközség rendtartásának elöírásait,

b) gondoskodik a tároló és a palackozó üzemének pincekataszteri nyilvántartásba vételéről,

c) nyilvántartást vezet a védett eredetü bor készletéről, annak változásáról a hatályos 
jogszabályban foglaltaknak megfelelöen, d) jelenti a védett eredetü borral kapcsolatos készletváltozást az Egri borvidék illetékes hegybírójának,

e) lehetővé teszi az ellenőrnek, hogy betekinthessen a védett eredetű bor nyilvántartásába, f) lehetővé teszi és eltüri a bortároló helységben a védett eredetű bor készletének ellenőrzését és a mintavételezést a palackozásra váró lédig tételek, valamint a lepalackozott védett eredetü bor esetén.

(5) Az Egri borvidéki palackozókban történt palackozás esetén a címkén, illetve palackon a „termőhelyen palackozva” felirat feltüntethető.

\section{Nyilvántartások}

16. $\S$

A szőlöültetvényre és borászati üzemre vonatkozóan - a jogszabályokban elöírtakon túl - a szőlő vagy a bor termelőjének az alábbi nyilvántartásokat kell vezetnie:

a) a szüreti helyszíni szemléröl szóló jegyzőkönyv, amely tartalmazza a termelő azonosító adatait, a helyszínen becsült termés mennyiségét, a refraktométerrel (korrekcióval hitelesített műszerrel) mért természetes alkoholtartalmat, a termés egészségi állapotának leírását, a minősítő nevét, a minősítés dátumát,

b) a védett eredetű borok ellenőrzéséről készült jegyzőkönyvet.

\section{Adatszolgáltatás}

17. $§$

A forgalomba hozatali engedéllyel rendelkező védett eredetű bortétel tovább feldolgozás céljára történő értékesítése esetén a bort palackozó borászati üzem köteles értesíteni a hegybírót a tovább feldolgozásra való értékesítésről és az értékesített mennyiségről az adásvételi szerződés megkötését követő 8 napon belül.

\section{Érzékszervi ellenőrzés}

18. $\S$

Az Egri borvidék forgalomba hozott és a kereskedelemben fellelhető védett eredetű boraiból az EBHT az érzékszervi minősítésre ellenőrzési mintát vásárolhat. A borminősítő bizottság érzékszervi vizsgálatán „nem megfelelt” minősítést kapott forgalomban lévő borra az EBHT titkára köteles hatósági vizsgálatot kérni.

\section{Jogkövetkezmények}

19. $\S$

(1) Azzal szemben, aki

a) a 7. §-ban meghatározott szabályokat megszegi,

b) a 8. §-ban írtakat nem tartja be,

c) az 1. számú mellékletben megadott védjegyet a forgalomba hozatal során olyan palackon

alkalmazza, ami nem az adott tételnek megfelelő forgalomba hozatali engedéllyel rendelkező bort tartalmazza,

d) a 15. §-ban szabályozott mintavételi eljárást meghiúsítja, vagy annak meghiúsítására 
törekszik,

e) nem a származási bizonyítvánnyal érintett tétellel azonos mintát szolgáltat, valamint f) a 16. §-ban meghatározott kötelezettségét megszegi, az EBHT titkárának elöterjesztésére, vagy önálló kezdeményezéssel a bor készítése szerinti illetékes hegybíró köteles eljárni.

(2) Az illetékes hegybíró az eljárása során csak szándékos vagy gondatlan magatartás esetén alkalmazhat felelősségre vonást és a hegyközség rendtartásában meghatározottakon túl az alábbi szankciókat alkalmazhatja:

a) írásban felszólítja a hegyközségi tagot a jogszabályoknak nem megfelelő cselekmény megszüntetésére, a mulasztás pótlására a határidő megjelölésével és a következményekre való felhívással, b) írásos elmarasztalás, hegyközségi nyilvános közzététel mellett, c) az eredetmegjelölés alkalmazásától való eltiltás 1-3 évig terjedően.

\section{Átmeneti intézkedések}

20. $\S$

(1) Az a termelő, aki 2009. december 31-e előtt termett szőlőből dűlőmegjelöléssel ellátott Egri Bikavér bort hozott, illetve hoz forgalomba, a borvidéki dülő nevének feltüntetése esetén az ugyanazon dülőből származó Egri Bikavér borának készítésekor a 10. § (6) bekezdése $b$ ) pontjának rendelkezései alól felmentést nyer az ültetvény fennállásáig, vagy arra az időre, amíg a kérdéses ültetvény fajtaösszetételét nem változtatja meg.

(2) Az a termelő, aki élni kíván az (1) bekezdésben említett jogával, e szándékáról legkésőbb 2010. augusztus 15-ig írásbeli nyilatkozatot kell adnia az illetékes hegyközség részére. A nyilatkozathoz csatolni kell az alábbiakat:

a) az ültetvény termőre fordítási jegyzőkönyve, vagy a 2010. előtti évjáratok szőlő származási bizonyítványai és

b) az adott bor címkéje.

(3) A hegybíró ezeket a dokumentumokat összeveti a hegyközségi nyilvántartásban szereplő adatokkal, és azok egyezősége esetén határozatában hozzájárulását adja az (1) bekezdésben említett felmentéshez.

\section{Záró rendelkezések}

\section{1.}

(1) Ez a rendelet a kihirdetését követő napon lép hatályba, egyidejüleg az Egri borvidék védett eredetű borairól szóló 130/2003. (XII. 31.) FVM rendelet 1 . §-a, valamint 10-15. §-a hatályát veszti. A 130/2003. (XII. 31.) rendelet 2-9. §-a 2010. július 31-én hatályát veszti.

(2) A rendelet 2-12. §-aiban foglalt rendelkezéseket először a 2010-ben szüretelt szőlőből készült borokra kell alkalmazni. 


\section{M2. DÜLŐ TÉRKÉP}

\section{Szarkás-dülő}

Kolompos-dülő

Kölyuktető

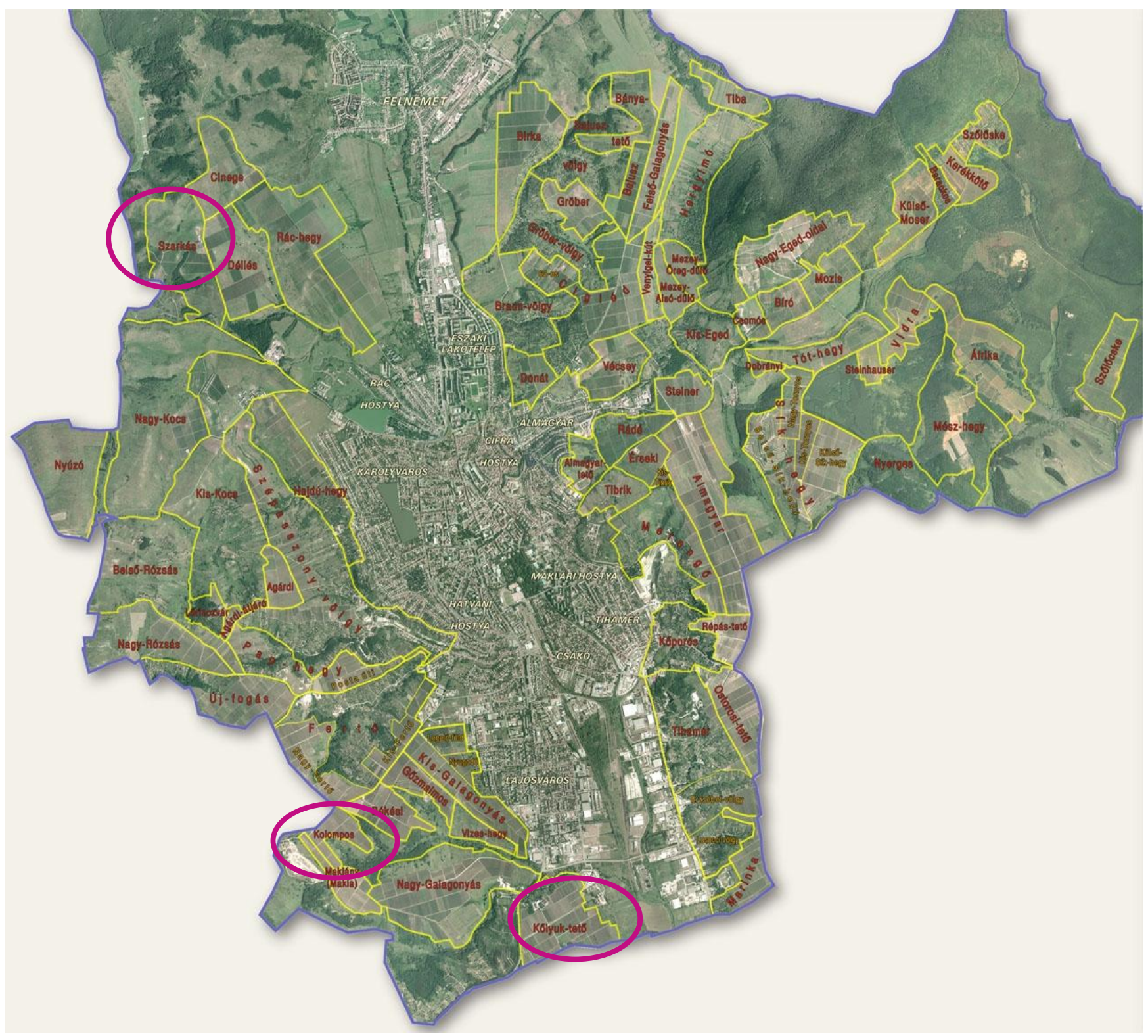

(Forrás: Eger Város Hegyközsége) 


\section{M3. 2007-ES ÉVJÁRAT KLIMATIKUS JELLEMZÖI}
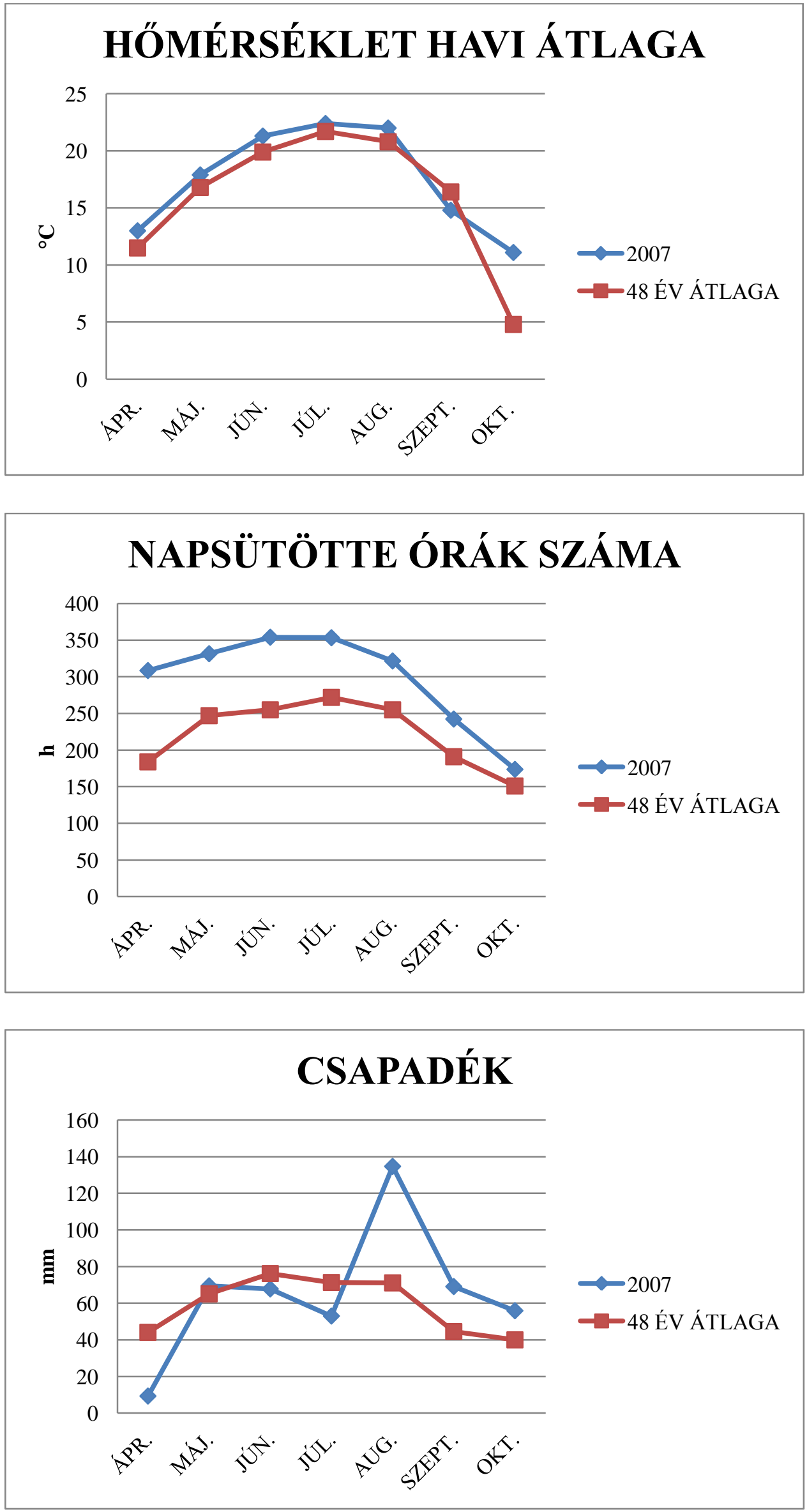
M4. 2008-AS ÉVJÁRAT KLIMATIKUS JELLEMZÖI
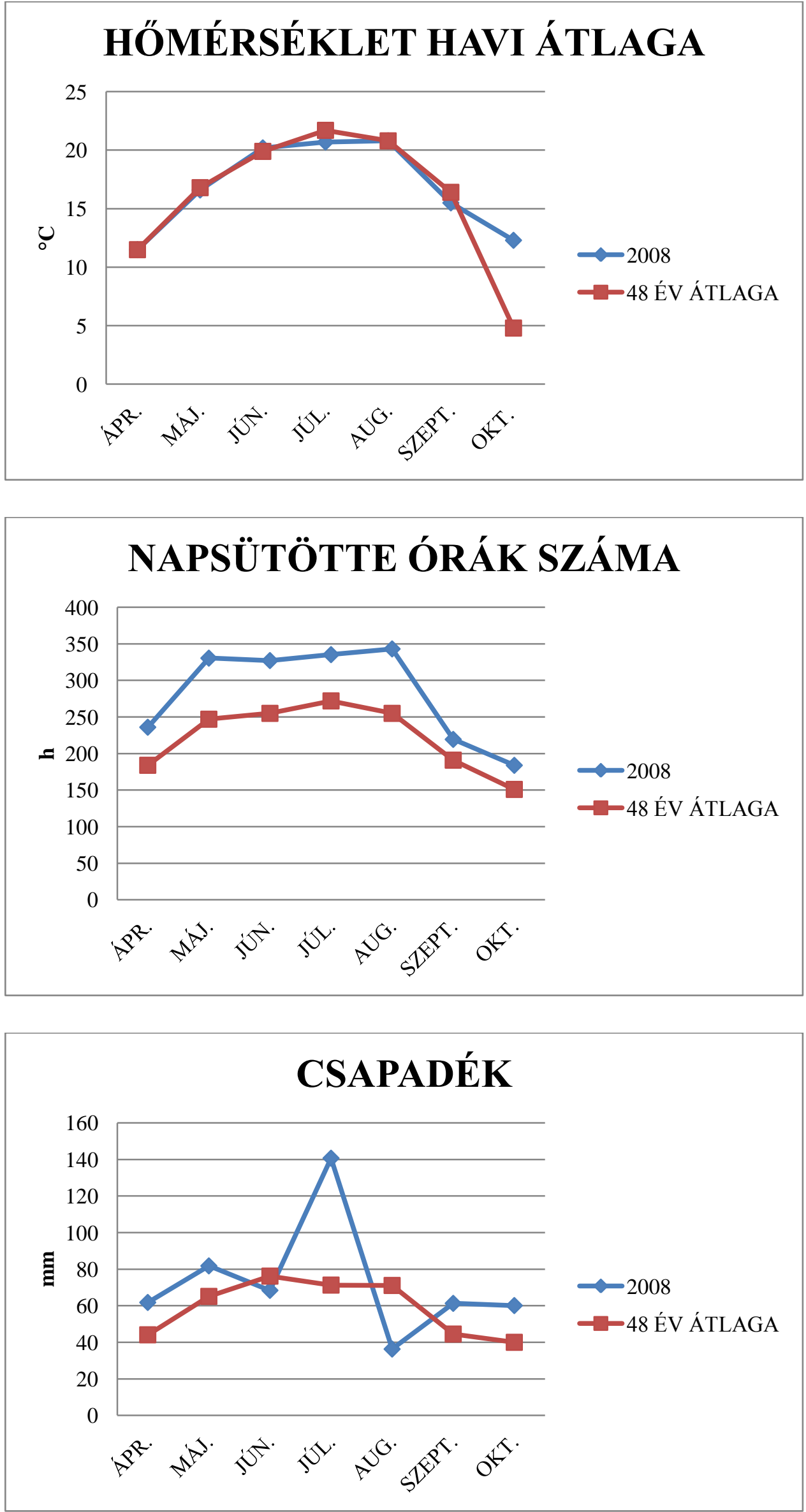


\section{M5. 2009-ES ÉVJÁRAT KLIMATIKUS JELLEMZÖI}
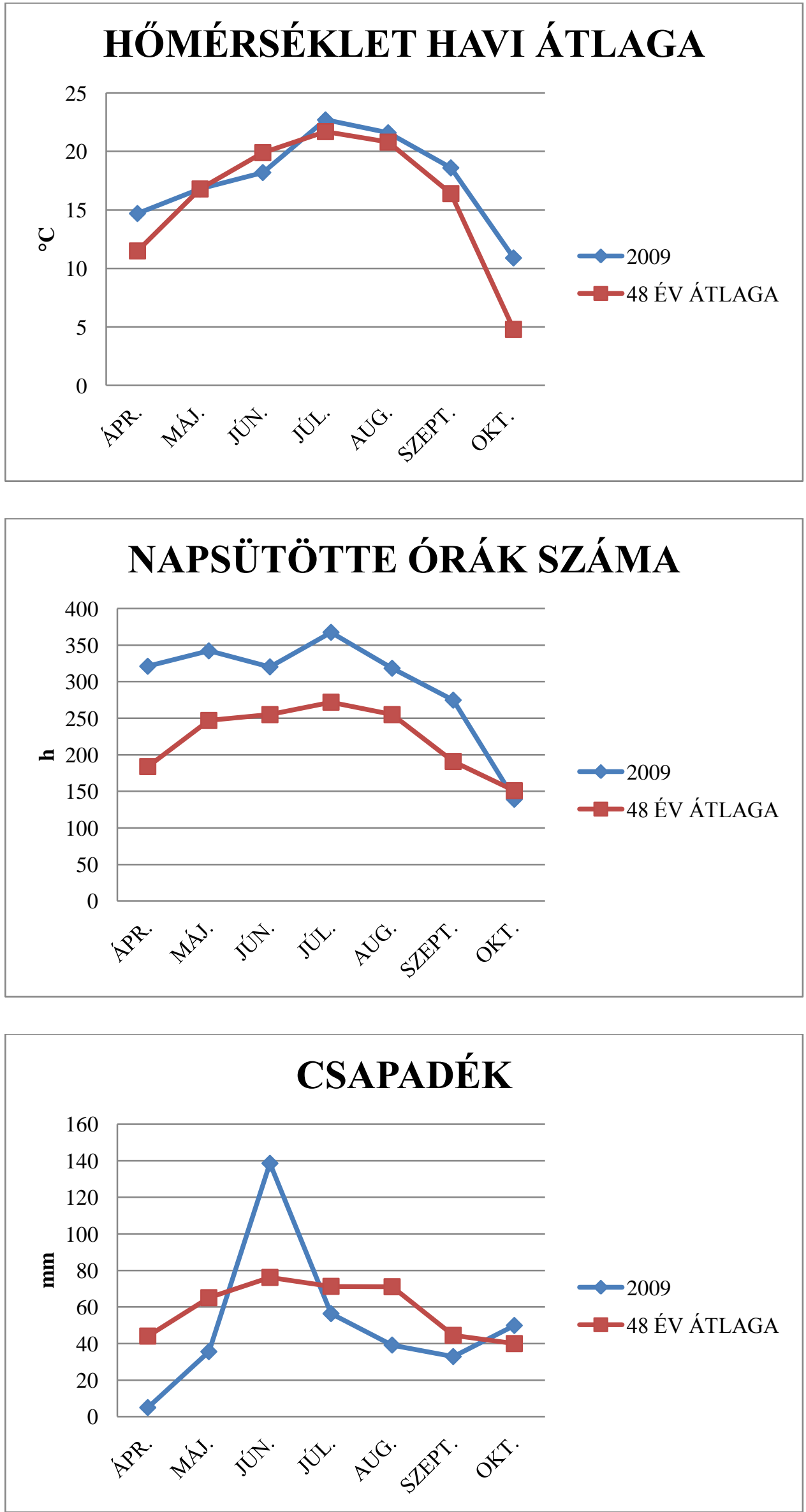
M6. SZŐLŐHÉJEXRAKTUMOK VIZSGÁLATÁNAK EREDMÉNYEI A 2007-ES ÉVJÁRATBAN

\begin{tabular}{c|c|c|c|c|c}
\hline FAJTA & $\begin{array}{c}\text { ANT. } \\
{[\mathrm{mg} / \mathrm{kg}]}\end{array}$ & $\begin{array}{c}\text { Ö.POL. } \\
{[\mathrm{mg} / \mathrm{kg}]}\end{array}$ & $\begin{array}{c}\text { KAT. } \\
{[\mathrm{mg} / \mathrm{kg}]}\end{array}$ & $\begin{array}{c}\text { LEUK. } \\
{[\mathrm{mg} / \mathrm{kg}]}\end{array}$ & $\begin{array}{c}\text { T-P } \\
{[\mathrm{mg} / \mathrm{kg}]}\end{array}$ \\
\hline BLAU.Váll & 2833 & 4462 & 1523 & 4666 & 20 \\
\hline BLAU.Test & 3256 & 5559 & 1672 & 5120 & 40 \\
\hline BLAU.Vég & 3533 & 5618 & 1822 & 5358 & 27 \\
\hline KF.Váll & 1971 & 4826 & 1195 & 6703 & 6 \\
\hline KF.Test & 1427 & 3652 & 820 & 4757 & 2 \\
\hline KF.Vég & 1543 & 3772 & 878 & 4508 & 5 \\
\hline ZW.Váll & 6709 & 12532 & 3532 & 17188 & 27 \\
\hline ZW. Test & 4062 & 10216 & 3453 & 15574 & 17 \\
\hline ZW.Vég & 4102 & 9312 & 3006 & 15102 & 16 \\
\hline
\end{tabular}

M7. SZŐLŐHÉJEXTRAKTUMOK VIZSGÁLATÁNAK EREDMÉNYEI A 2008-AS ÉVJÁRATBAN

\begin{tabular}{c|c|c|c|c|c}
\hline FAJTA & $\begin{array}{c}\text { ANT. } \\
{[\mathrm{mg} / \mathrm{kg}]}\end{array}$ & $\begin{array}{c}\text { Ö.POL. } \\
{[\mathrm{mg} / \mathrm{kg}]}\end{array}$ & $\begin{array}{c}\text { KAT. } \\
{[\mathrm{mg} / \mathrm{kg}]}\end{array}$ & $\begin{array}{c}\text { LEUK. } \\
{[\mathrm{mg} / \mathrm{kg}]}\end{array}$ & $\begin{array}{c}\text { C-P } \\
{[\mathrm{mg} / \mathrm{kg}]}\end{array}$ \\
\hline PN. Váll & 1271 & 3324 & 1011 & 2226 & 16,6 \\
\hline PN. Test & 1559 & 4030 & 953 & 2298 & 33,3 \\
\hline PN. Vég & 1446 & 3780 & 1104 & 2620 & n.d. \\
\hline ME. Váll & 1935 & 4846 & 4564 & 4503 & 20,1 \\
\hline ME. Test & 1511 & 4203 & 1081 & 4028 & 12,2 \\
\hline ME. Vég & 1626 & 4834 & 1028 & 3773 & 18 \\
\hline CF. Váll & 1718 & 4895 & 528 & 4677 & 11,2 \\
\hline CF. Test & 1417 & 4318 & 284 & 3790 & 6,5 \\
\hline CF. Vég & 1971 & 6442 & 360 & 5508 & 16,1 \\
\hline
\end{tabular}


M8. SZŐLŐHÉJEXTRAKTUMOK VIZSGÁLATÁNAK EREDMÉNYEI A 2009-ES ÉVJÁRATBAN

\begin{tabular}{l|c|c|c|c|c|c|c}
\hline FAJTA & $\begin{array}{c}\text { ANT. } \\
{[\mathrm{mg} / \mathrm{kg}]}\end{array}$ & $\begin{array}{c}\text { Ö.POL. } \\
{[\mathrm{mg} / \mathrm{kg}]}\end{array}$ & $\begin{array}{c}\text { KAT. } \\
{[\mathrm{mg} / \mathrm{kg}]}\end{array}$ & $\begin{array}{c}\text { LEUK. } \\
{[\mathrm{mg} / \mathrm{kg}]}\end{array}$ & $\begin{array}{c}\text { T-P } \\
{[\mathrm{mg} / \mathrm{kg}]}\end{array}$ & $\begin{array}{c}\mathrm{C}-\mathrm{R} \\
{[\mathrm{mg} / \mathrm{kg}]}\end{array}$ & $\begin{array}{c}\mathrm{T}-\mathrm{R} \\
{[\mathrm{mg} / \mathrm{kg}]}\end{array}$ \\
\hline TU. Váll & 5538 & 9185 & 9954 & 15294 & 0,8 & 2 & 80 \\
\hline TU. Test & 5085 & 8554 & 8604 & 14855 & 0,2 & 27 & 25 \\
\hline TU. Vég & 4895 & 8345 & 8457 & 12649 & 0,3 & 33 & 18 \\
\hline BK. Váll & 8978 & 13239 & 18264 & 14279 & 1,3 & n.d. & 28 \\
\hline BK. Test & 7819 & 10283 & 14190 & 12737 & 0,7 & n.d. & 23 \\
\hline BK. Vég & 7018 & 9066 & 11952 & 11860 & 1,7 & n.d. & 44 \\
\hline SY. Váll & 5644 & 6845 & 9760 & 14838 & 1,5 & 34 & 28 \\
\hline SY. Test & 4866 & 5905 & 8375 & 8403 & 0,5 & 53 & 12 \\
\hline SY. Vég & 5517 & 6612 & 8915 & 9274 & 2 & 59 & 13 \\
\hline
\end{tabular}

